LBL -34045

UC-1600

\title{
Residential HVAC Data, Assumptions and Methodology for End-Use Forecasting with EPRI-REEPS 2.1
}

\author{
Francis X. Johnson, Richard E. Brown, James W. Hanford, Alan H. Sanstad and
} Jonathan G. Koomey

\author{
Energy and Environment Division \\ Lawrence Berkeley Laboratory \\ University of Califomia \\ Berkeley, CA 94720
}

June 1994

This work was supported by the Assistant Secretary for Energy Effictency and Renewable Energy, Office of Planning and Analysis and Ofīce of Building Technologies, and the Deputy Undersecretary of the Office of Poliky, Planning, and Analyais of the US. Departument of Energy under Contract No. DE-ACO3-76SFOO098. 


\section{DISClaimer}

This report was prepared as an accoumt of work sponsored by an agency of the United Stetes Government. Neither the United States Government nor any agency thereof, nor any of their employees, make any warranty, express or implied, or assumes any legal liability or responsibility for the accuracy, completeness, or usefulness of any information, apparatus, product, or process dhaclosed, or represents that its use would not infringe privatety owned rights. Reference herein to any specific commercial product, process, or service by trade name, trademark. manufacturer, or otherwise does not necessarily constitute or imply its endorsement, recornmendation, or favoring by the United States Government or any agency thereof. The views and opinions of authors expressed herein do not necessarily stete or reflect those of the United States Government or any agency thereof. 


\section{DISCLAIMER}

Portions of this document may be illegible in electronic image products. Images are produced from the best available original document. 


\begin{abstract}
This report details the data, assumptions and methodology for end-ose forecasting of space conditioning energy use in the U.S. residential sector. Space conditioning end-uses include Heating, Ventilation and Air Conditioning (HVAC). Our analysis uses the modeling framework provided by the HVAC module in the Residential End-Use Energy Planning System (REEPS), which was developed by the Electric Power Reseanch Institute (McMenamin ef al. 1992). This modeling framework theats space conditioning separately from appliances such as refrigerators or water heating doe to the complex physical and economic interactions that characterize HVAC systems, and because space conditioning is the most significant end-use of residential energy in the United States. Space condjtioning accounts for approximately $30 \%$ of electricity consumption, $70 \%$ of natural gas consumption and $90 \%$ of oil consumption in the U.S. residential sector. In terms of primary energy, space conditioning represents over half of all energy consumption in residences (EIA 1993).

This report is primarily methodological in nature, taking the reader through the entire process of developing the baseline residential space conditioning end-use models. Analysis steps documented in this report include: defining the thermal shell characteristics, gathering technology and market data for HVAC equipment and systems, developing cost data for the various components of the thermal shell and HVAC systems, and specifying decision models (both the functional form and equation parameters) to forecast future purchase decisions by households. Our implementation of the REEPS 2.1 modeling framework draws on the extensive technology, cost and market data assembled by LBL for the purpose of analyzing federal energy efficiency standards. The resulting residential HVAC forecasting model offers a flexible and accurate tool for analyzing the effect of policies at the national and north/south levels.
\end{abstract}




\section{FOREWORD AND ACKNOWLEDGMENTS}

This project was undertaken at Lawrence Berkeley Laboratory (LBL) under the direct supervision of Jonathan Koomey, and with the guidance of James E. McMahon and Mark D. Levine. The purpose of this work is to create a well-documented end-use forecasting model for the residential sector, and to use that model to analyze national policies affecting the efficiency and parterns of energy use in the U.S.

The work adopts the modeling framework of the Residential End-Use Energy Pianning System (REEPS) developed for the Electric Power Research Institute (EPRI). This report is one of a series of three reports documenting the residential sector end-use forecasting project using EPRIREEPS 2.1, which is the most recent version of the computer software. The first report in the series summarizes the model framework and inputs, and presents the results of the baseline forecast for each end-use (LBL-34044). The other two reports detail the data, assumptions and methodology for the two distinct groups of end-nses in the residential sector. This report (LBL34045), the second in the series, covers the space conditioning end-uses of Heating. Ventilating and Air Conditioning (HVAC) while the third report (LBL-34046), covers appliances, including water heating, refrigerators, freezers, clothes washers, clothes dryers, dishwashers, lighting and cooking.

We are gratefol for the funding and insights provided by Eric Petersen and David Patton of the Office of Planning and Assessment, Dick Jones of the Office of Building Technologies, and Ted Williams and Jim Kelly in the Office of Policy, Planning, and Analysis of the U.S. Department of Energy.

This work was supported by the Assistant Secretary for Energy Efficiency and Renewable Energy, Office of Planning and Analysis and Office of Building Technologies, and the Deputy Undersecretary of the Office of Policy, Planning, and Aualysis of the U.S. Department of Energy under Contract No. DE-AC03-76SF00098. 


\section{TABLE OF CONTENTS}

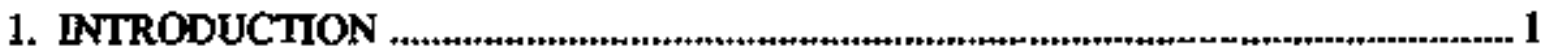

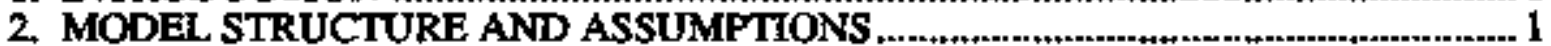

2.1. REEPS Modeling Framework ...................................................................2

2.2. HVAC Model Siructure ................................................................................ 3

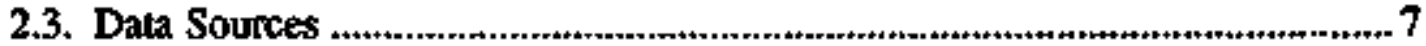

2.4. Potential Applications ….................................................................................

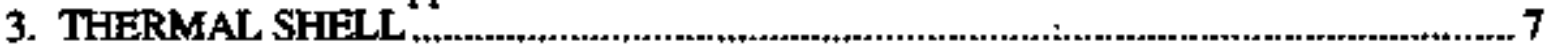

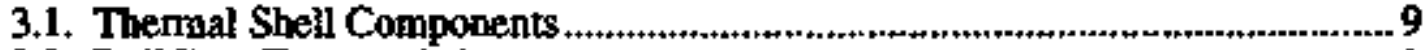

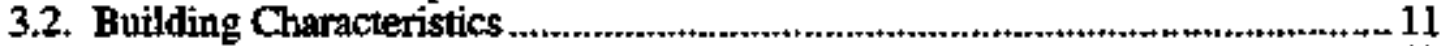

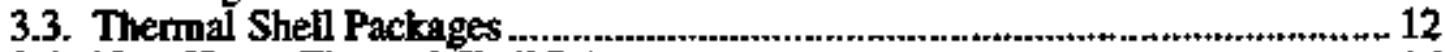

3.4. New Home Thermal Shell Prices ........................................................................ 16

4. EQUIPMENT DATA AND MARKET SHARES

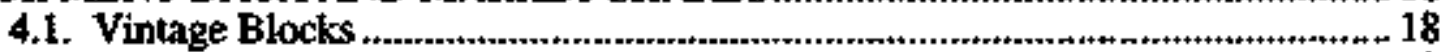

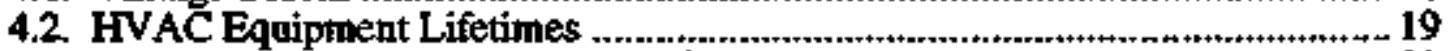

4.3. HVAC Equipment Capacity and Efficiency Data........................................20

4.4. Unit Energy Consumption Estimates...........................................................22

4.5. HVAC Eguipment Market Shares.................................................................2 23

5. EQUIPMENT SIZE, USAGE AND PRICE MODELS ......................................... 26

5.1. Equipment Size Models ...........................................................................26

5.2. Unit Energy Consumption and Usage Models................................................. 29

5.3. Heating and Cooling Equipment Prices .......................................................... 29

5.4. Distribution System Prices ............................................................................... 30

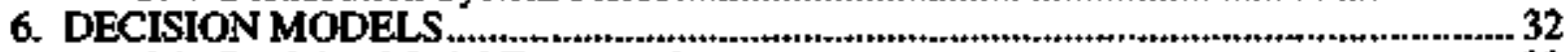

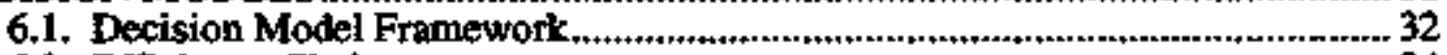

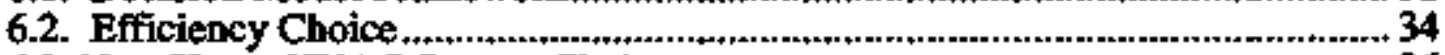

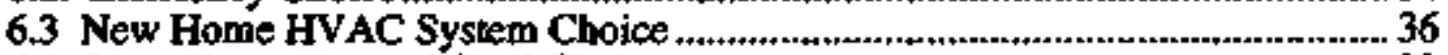

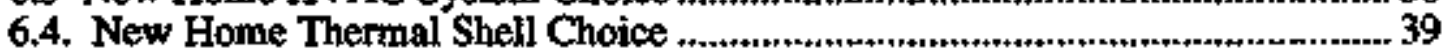

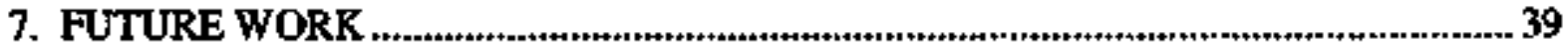

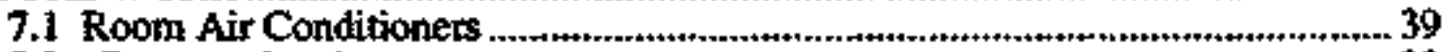

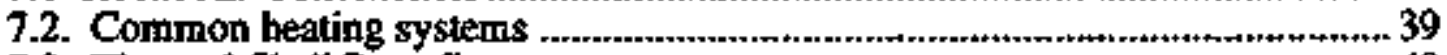

7.3. Thermal Shell Retrofits ................................................................................40

7.4. The Rebound Effect ................................................................................... 40

7.5. Efficiency Choice......................................................................................... 40

7.6. Passive Solar Featires................................................................................ 41

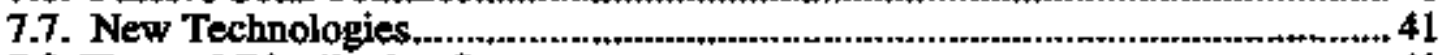

7.8 Thermal Distribution Systems ................................................................... 41

8. CONCLUSIONS

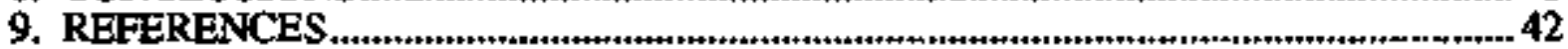

APPENDIX A: THERMAL SHELL COMPONENT LOADS ….................................... 47

APPENDIX B: HVAC EQUIPMENT VINTAGE BLOCKS ...........................................49

APPENDIX C: SZE AND EFFICIENCY DISTRIBUTIONS ….................................. 54

APPENDIX D: PEAK LOAD CALCULATIONS ..................................................

APPENDIX E: EQUIPMENT PRICE DATA AND PARAMETER ESTIMATION ........64

APPENDIX F: REGIONAL HVAC SYSTEM CHOICE MODEES................................ 72

APPENDLX G: QUALITATIVE CHOICE ANAL YSIS ………....................................

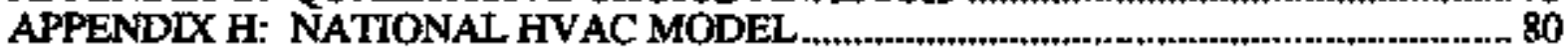

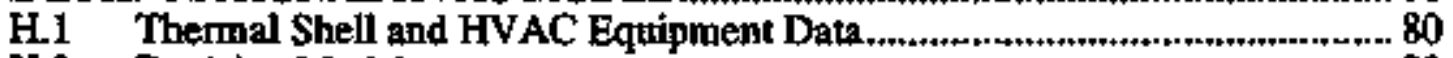

H.2 Decision Models ..................................................................................... 88

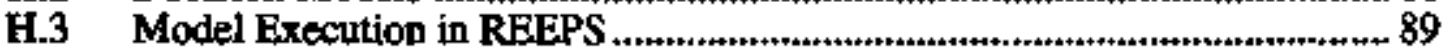

H.4 Choosing the Appropriate Model ........................................................... 89

H.5 National HVAC Model Summary ........................................................ 90

APPENDIX I: REDUCED-FORM THERMAL INTEGRITY COST CURVES ............. 91 


\section{INTRODUCTION}

This report details the data, assumptions and methodology for end-use forecasting of space conditioning energy use in the U.S. residential sector. Space conditioning end-uses include Heating, Ventilation and Air Conditioning (HVAC). Onr analysis nses the modeling framework provided by the HVAC module in the Residential End-Use Energy Planning System (REEPS), which was developed by the Electric Power Research Institute (McMenamin et al. 1992). This modeling framework treats space conditioning separately from appliances such as refrigerators or water heating due to the complex physical and economic interactions that characterize HVAC systems. The appliance end-uses are discussed in a separate report (Hwang et al. 1994). The HVAC end-use represents the most significant area of residential energy consumption in the United States. Space conditioning accounts for approximately $30 \%$ of electricity consumption, $70 \%$ of natural gas consumption and $90 \%$ of oil consumption in the U.S. residential sector. In terms of primary energy, space conditioning represents over half of all energy consumption in residences (EIA 1993). Both the complexity and the sheer magnitude of energy consumption in this end-use suggest that space conditioning must be ascribed an important role in any residential sector policies or programs aimed at improving energy efficiency and/or reducing energy consumption. The baseline forecast using the REEPS model described here is presented in a separate report (Koomey et al. 1994a).

Engineering-economic models such as REEPS offer a means of assessing future trends in energy consumption at the end-use level ander differing assumptions, scenarios or policies. Such models attempt to characterize the long-term structure and patterns of energy consumption in homes. They are called end-use forecasting models because they generally include considerable end-use detail. They rely on data regarding the building stock, the equipment available for supplying energy services, and historical patterns of end-use energy consumption in homes. For HVAC analysis, which is the focus of this report, engineering data on the building thermal shell and energy-using equipment are combined with economic parameters regarding purchase and usage of the equipment. At the national level, these end-use forecasting models facilitate the apalysis of energy conservation programs and policy initiatives that are widely applicable and broad in their scope, such as residential appliance standards (US DOE 1989b, US DOE 1990, US DOE 1993) and national energy policy initiatives (EIA 1990). Utilities rely on end-use forecasting models in order to assess market trends for new technologies (McMenamin et al. 1992) and in the development of Demand-Side Management (DSM) programs (Hummel and McMenamin 1992).

This report details the supporting data, model parameters, and methodology for HVAC models developed for use with REEPS 2.1. In Section 2 we outline the HVAC modeling framework provided by REEPS and the end-use structure and assumptions we adopted for this analysis. In Section 3, we define the thermal shell characteristics, which serve as the starting point for the analysis of heating and cooling demand. In Section 4, we explain the technology and market data for HVAC equipment and systems. Section 5 includes the development of cost data and functions for the various components of the themal shell and HVAC systems. Section 6 details the development of the various decision models used to forecast future purchase decisions by households, including the functional form and the paraneters estinated for the models. Section 7 outlines areas for future work which are important to end-use forecasting for space conditioning, but could not be included in the model due to data and time limitations. In Section 8 we summarize and conclude the report.

\section{MODEL STRUCTURE AND ASSUMPTIONS}

In this section of the report we outline the REEPS modeling framework and the assurnptions and data structure we have adopted in configuring the HVAC model. In Section 2.1, we describe the 
general features of residential end-use forecasting and the particular features of the REEPS modeling framework, emphasizing those aspects relevant to the HVAC model. In Section 2.2, we explain the methodology for structuring the HVAC model and some of the conventions we adopted in setting up the model. In Section 2.3, we provide an overview of the data sonrces we used to develop the structure, inputs and parameter estimates for the HVAC model. In Section 2.4, we discuss some of the potential applications of the model in analyzing impacts of government policies, utility programs, changes in technology development and adoption, and economic scenarios.

\subsection{REEPS Modeling Framework}

The basic assumptions and structure of residential end-use forecasting are quite similar across both different modeling frameworks and different end-uses (Johnson et al. 1992). The household is considered the fundamental unit for energy consumption. The physical housing stock is defined by its thermal properties, while energy-using equipment is described by variables such as size (or capacity) and efficiency. Macroeconomic and demographic variables that change over time include the housing stock, household size, fuel prices and household income. Technology data characterize the existing and/or future stock of equipment and allow the formulation of functional relationships to use in the forecast. Consumer data describe ownership patterns for equipment and appliances, generally segmented by housing type. Consumer aftitudes toward energy efficiency investments are typically characterized by parameters that represent economic tradeoffs between purchase price and operating cost. Market shares are estimated for each technology or fuel for a given end-use or energy service and the models adjust these market shares over time as housetiolds purchase equipment.

The EPRI-REEPS model is one of several prominent end-use forecasting models that have been developed since the mid-1970s. One of the earliest residential end-use forecasting models was developed at Oak Ridge National Laboratory (Hirst and Carmey 1978). This model was later modified at the Lawrence Berkeley Laboratory (McMahoa 1987) for the analysis of residential appliance standards. REEPS has been nsed since the early 1980s both as a tool for national policy analysis and subsequently as an analytical tool for electric utilities to forecast long-term residential energy demand (EPRI 1982). The first version of the model, REEPS 1.0, relied on an econometric/micro simulation approach to estimate energy consumption for a given sample of households (Cowing and McFadden 1984). The newest version of the model, REEPS 2.1, is quite different in that it provides the user with a generalized modeling framework rather than attempting to simulate a particular set of households. As a result, REEPS 2.1 does not have the theoretical foundation and household-specific data enumeration offered by the micro simulation approach in REEPS 1.0 (Cowing 1992).

This latest version of REEPS incorporates the basic features of residential end-use forecasting into a generalized modeling framework in which the user has considerable control over the algorithms and model structure (McMenamin et al. 1992). All REEPS users wotk within a common software framework. which allows them to focus on the substantive aspects of the analysis and avoid potential programming enrors introduced by changes in the software source code. This framework provides greater flexibility over more traditional models which are "hardwined" for particular formulations of residential sector energy use. Rather than relying on a fixed set of equations and/or parameters, the user can precisely specify the equations used to forecast future equjpment and housing characteristics. Both the functional form and paraneters included in these equations are open to modification by the user. This enables modeling of a wide range of scenarios and policies at varying levels of disaggregation without ever changing the computer program itself. This improved modeling flexibility, however, brings with it considerably more responsibility on the part of the user in configuring the input data. Each distinct set of tata and parameters resnlts in a different model, with the result that there can be considerable variation in the fortast results even when exogenous variables remain the same. In 
effect, the "model" consists of the structure, data, and algorithms developed by the user, with the REEPS computer program itself as a modeling shell that inparts a higher level structure and consistency to the analysis.

REEPS 2.1 provides a distinct modeling component for the space conditioning end-uses, with the capability to mockl heating, ventilation and air conditioning (HVAC). The HVAC module in REEPS derives its higher-level structure front other input variables shown in Figure 2.1. Exogenous variables include macroeconomic projections stch as income and housetiold size, along with other external parameters needed by the model. Fuel price projections are implemented as exogenous time series for each fuel and rate class used in the model. Households data allow the user to forecast changes to the housing stock based on separate decay rates for each housing type and vintage block. Demographic segmentation divides the HVAC market into different segments based on household charactetistics such as income or hoursehold size, allowing purchase decisions to be differentiated between the segments. These other input sets precede the specification of the HVAC model itself because they define important elements of the HVAC model structure, such as the housing types specified in the Households module. Data from these input sets are used as drivers in forecasting the size, characteristics, and usage of the space conditioning equipment and housing stock. In general, REEPS uses data in the form of an average value within a market segment (house type, income, etc.), rather than a distribution of values that would more closely approximate the actual situation. This data stucture could potentially introduce aggregation bias into the forectasts, which the user may attempt to minimize by dividing the market into sinaller segments (thus the average values input to REEPS represent fewer houses).

\subsection{HVAC Model Strueture}

In forecasting energy consumption for space conditioning in -U.S. residences, some level of regional disaggnegation is desirable due to the wide differences in climate and the associated heating and cooling requirements. However, regional disaggregation is often not possible because detailed data such as that required to describe the technology characteristics of heating and cooling equipment is often not available at the regional level. Moreover, regional segmentation is not easily accomplished in REEPS, partially becanse most users of REEPS are utilities. who need not be concerned with climate differences. Consequently, we chose an internediate level of regional disaggregation, North and South, as used in a recent analysis of conservation potential in the U.S. residential sector (Koomey et al. 1991a). As illustrated in Figure 2.2, the North consists of Federal negions 1, 2, 3, 5, 7, 8 and 10 while the South consists of Federal regions 4, 6 and 9. This requires two distinct "implementations" of REEPS, which can then be aggregated to yield national results. Our regional breakup allows us to capture climate-related characteristics of heating and cooling without stretching the modeling framework beyond what current data can support. At the same time, we have adopted a methodology throughout the analysis which is independent of the number of regions, so that the framework could include more regions if more detailed data becane available at the regional level.

While regional disaggregation should yield more accurate modeling results, there are certain modeling applications that do not allow the time to set-up and run the regional models. For these quick response situations, we have developed a national (one-region) REEPS HVAC model. The structure and inputs to this model are documented in Appendix $\mathrm{H}$. In general, the structure and data sources used in the rational model are identical to the regional models. 
Figure 2,1: Relationships among REEPS Input Sets

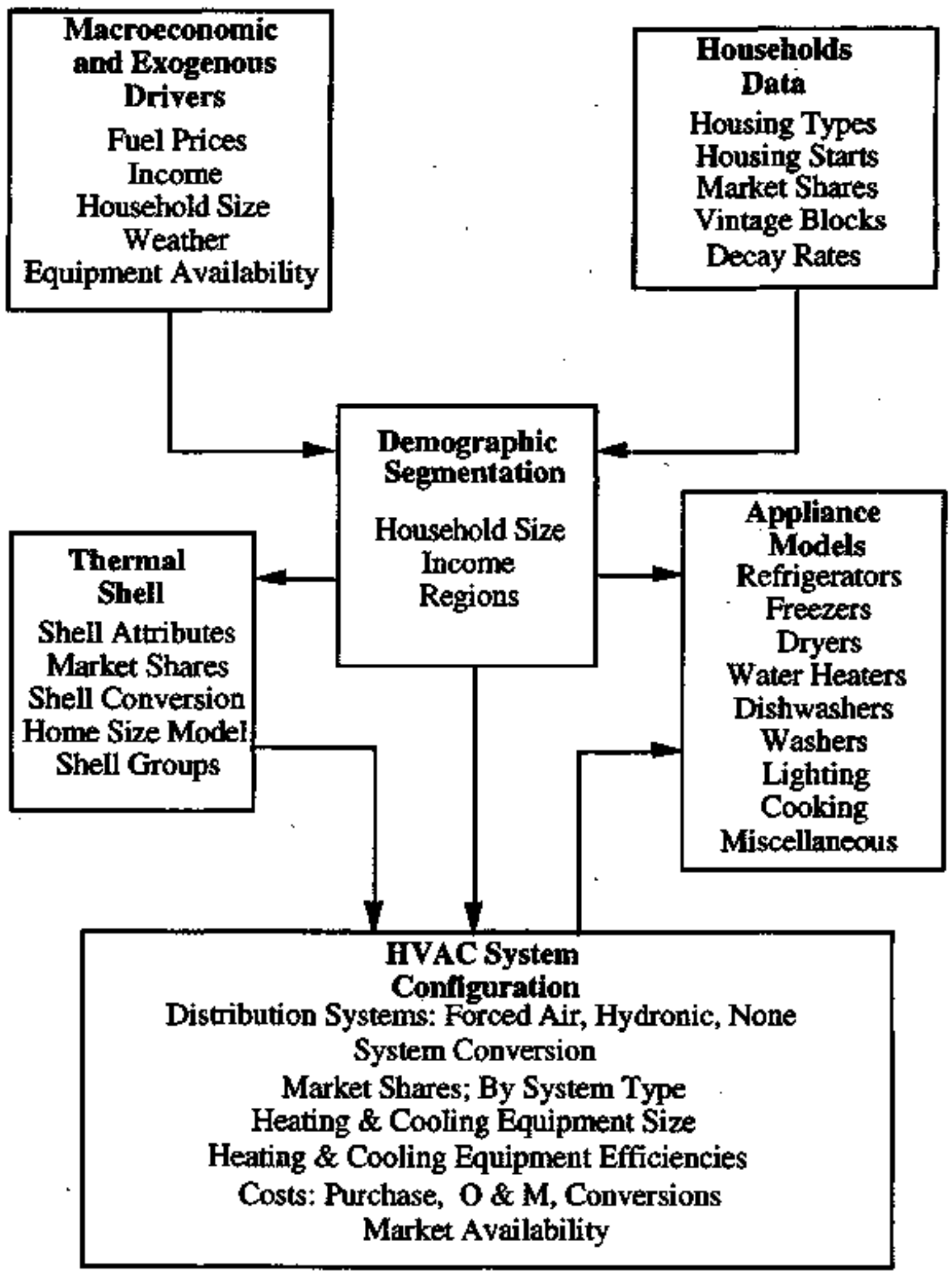




\section{Figure 2.2: Map of Regions Used in REEPS HVAC Model}

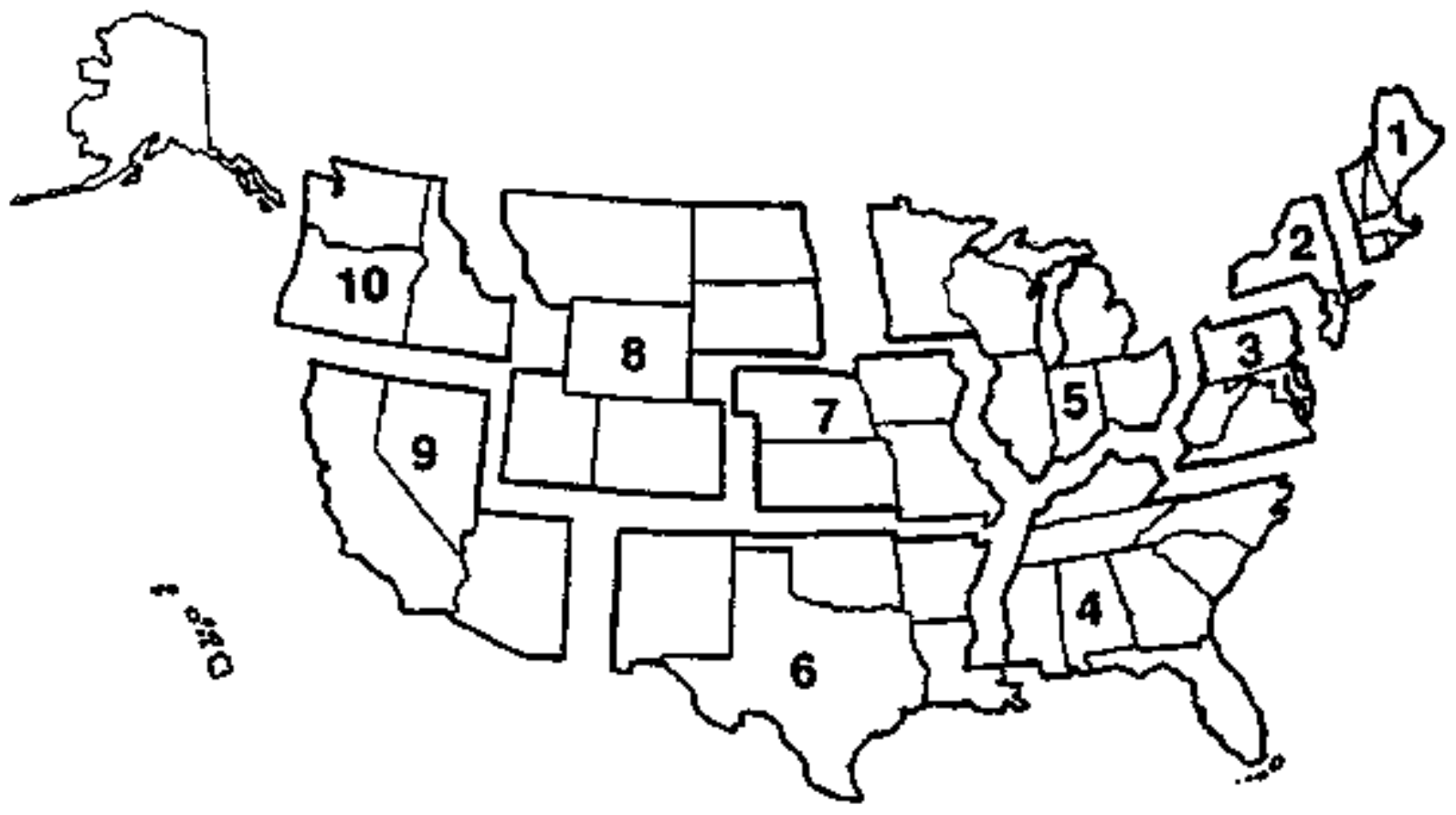

Rainina 1

No Eximat

Connecurat (CT)

Maine (ME)

Masechusets (MG)

Nrw Hampahir (NIt)

Rhode idiad (RT)

Vttonoel (VT)

Retive 2

Ner Yooly

Nes Jerey

New Jeney (Nt)

New Vork (NY)

Retion 3

Mtil Atins

Dirmate (DE)

Districa of Colwinbie (DC)

Maryland (MO)

Penasylyana (PA)

Virtinis (VA)

Wea Virgin (WV)
Prosion 4

Serth Aunotis

Alphens (AL)

Fionida (FL)

Goutas (OA)

Keriudsy (Kn)

Mithripp (MS)

North Cradiens (NCC)

South Crolona (SC)

Teansuce (TN)

Reales s

Mrinet

tllinos (IL)

Indiann (AN)

Mickizan (MIt)

Mtintwose (MN)

Ohis (Ot)

whoopste (W)
Rejea 4

Somplatin

Arkinats (AR)

Lotsing (LA)

Non Moniso (NM)

Otahomin (OK)

Tex:* (TX)

Dadet

Centran

lowe (iA)

Karen (KS)

Misown (MO)

Nebriti (NE)
Bedion

Necth Contel

Colonto (CO)

Moninin (MT)

Nonth Dikos (ND)

Souch Dakes (SO)

Uneth (UT)

wyomine (WN)

Anderat

Wit

Adrone (AZ)

Cabionin (CA)

Howi: (H)

Nevade (NV)

Reto 10

Nertinetet

Ateto (AK)

Jdaho (FD)

Oretron (OR)

Weringten (WA)

South Region is deftued as Federal Regions 4,6, and 9.

Norh Region is defined as Fexteral Regions $1,2,3,5,7,8$, and 10 
This analysis distinguishes between four housing types: small single-family homes, large singlefamily homes, multifamily homes, and manufactured homes. Each housing type has characteristic HVAC-system energy consumption and market behavior. We separated the two types of single-family homes by using 1800 square feet heated floor area as the dividing line between large and small homes. ${ }^{1}$ The distinction between small and large single-family homes is an important one, for a number of reasons. First. REEPS does not model the building dimensions of new homes separately from existing homes. We know, however, that homes being built today are substantially larger on average than existing homes. Therefore, we divide single-family homes by floor area so that the small category better describes existing homes, while the large category better describes new homes. Second, larger homes are generally 2-story homes, which have different thermal characteristics than 1-story homes of the same floor area. Furthermore, as Figure 2.3 shows, 1800 square feet is roughly the break point for single-family construction practices in the U.S. More than $50 \%$ of homes in each category larger than 1800 square feet are 2-story homes while more than $50 \%$ of homes in each category smaller than 1800 square feet are 1-story. ${ }^{2}$ Finally, the heating and cooling requirements are different for large and small homes, with the result that the ecomomics of choosing among HVAC systems and thermal shells is also quite different. We can thus capture this market effect in our model.

Figure 2.3: Shares of 1-Story and 2-Story Single-Family Homes by Heated Fioor Area

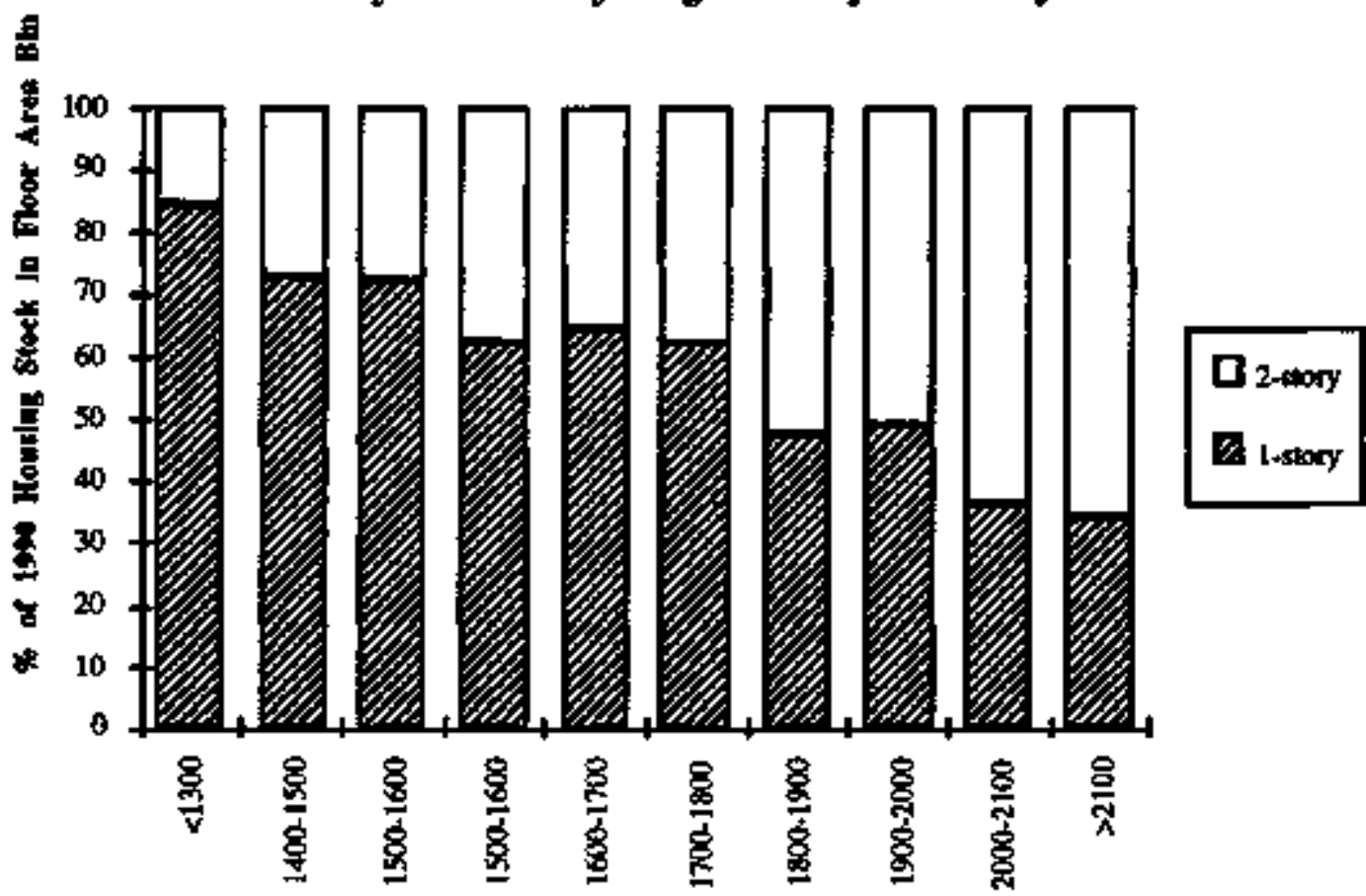

Abortopade Heated Floor Ares

Source: 1990 RECS (EIA 1993).

1 We consider ooly the above-grack heated area, based on RECS deta, to exclude basemets from the calcniation of floor aree. The dividing point has also been chosen becmuse the median beated floos area for new construction in the base year of 1990 is approximately 1800 square feet (ASE et al. 1991). Note that the national model described in Appendix $\boldsymbol{H}$ does not distinguist between large and small single-family bonse types.

2 Split-kevel bomes and homes with more than 2 stories are trefted as 2 -story homes, although these males up a small percentige of all homes. 
The HVAC model has four types of inputs: (1) thermal shell configurations; (2) HVAC technologies and systems characteristics; (3) HVAC equipment size, usage, and cost models; and (4) decision models for purchases of equipment and themral shells. The themal shell prototypes are configured using either whole-house U-values to represent thermal integrity or by specifying the U-values of the building components such as windows and ceilings. We chose the latter approach. The technologies to be defined include heating and cooling equipment and distribution systems. These technologies are then grouped into HVAC systems. The decision models are the basis of REEPS' forecasting capabilities, and can be of two types: reduced-form or logit choice models. The reduced-form models are used to forecast average values for important properties of technologies and systems that change over time, such as cost, size, efficiency or usage. The logit choice equations estimate the market shares of technologies over time based on a user-specified utility function. The main part of this report devotes a section to each of these four components of the HVAC model.

\subsection{Data Sources}

The REEPS 2.1 modeling framewotk is data intensive, requiring data at the household level as well as detailed data on the characteristics of HVAC equipment and themal shells. The primary source of data for our analysis is the 1990 Residential Energy Consumption Survey (RECS) conducted by the Energy Information Administration (EIA 1989, EIA 1992, EIA 1993). For data on heating and cooling equipment, we rely on annual records provided by trade groups on the shipments, efficiency and in certain cases the size (capacity or volume) of the equipment (AHAM 1991, ARI 1991, GAMA 1992). For cost data, we draw on published cast estimates of the R.S. MEANS company (R.S. MEANS Co. 1991b, R.S. MEANS Co. 1991c) and engineeringcost data developed by the ADM corporation (ADM 1987). For thermal shell data, we use estimates of prototype population characteristics for single-family buildings (Ritschard et al. 1992), multifamily buildings (Ritschard and Huang 1989), and manufactured homes (Koomey et al. 199 la). For new homes, we used survey data by state from the National Association of Home Builders (NAHB 1989). Other miscellaneous sources provided data where it was not available from these main sources.

\subsection{Potential Applications}

Within the HVAC module of REEPS 2.1, the user can model a variety of policies and impacts. Future market conditions and policies can be modeled by modifying relevant parameters, data structure, functional equations or control data. For instance, new technologies can be defined to satisfy markets or areas of demand that are expected to develop. Table 2.1 lists some of the impacts that can be modeled and the policy handles availabie for this purpose. We group these according to the major building component to which they apply: the thermal shell, heating and cooling equipment, or distribution systems. Policies can also be modeled through exogenons variables, such as fuel prices, that pertain to any end-use and can be modified directly in the input sets. The list in Table 2.1 is by no means exhaustive; the policies that can be nnodeled are limited to some extent only by the imagination of the modeler or policy analyst.

\section{THERMAL SHELL}

The themal shell of a building refers to its physical properties with respect to the flow and distribution of heat, without considering the occupants or their behavior. The REEPS model provides two altemative methods for configuring thermal shells to represent the physicaj characteristics of the residential builfing stock. One option is a whole-house U-value index, in which each discrete thermal shell is characterized by a single heat-load (heating) multiplier and a single heat-gain (cooling) multiplier. The second option is a multiple-attribute approach in which the user builds the thermal shell prototypes within the REEPS model by defining specific attributes representing important thermal components, such as windows and ceilings. The user 
then chooses the appropriate number of levels or values for each attribute, such as insulation levels (R-values) in the case of walls or ceilings. Weighting factors are then calculated for each housing type to represent the contribution of each attribute to the whole-house heat gain and heat loss, according to its relative surface area and heat transfer properties. The user then "builds" a set of packages or prototypes by choosing combinations of different attribule levels to represent the thermal shells to be used in the model. The heat gain and heat loss multipliers for the shell are a linear combination of the specific attributes using the weighting factors.

\section{Talle 2.1: Policy Handles in EPRI-RERTS HVAC Modale}

\begin{tabular}{|c|c|}
\hline Area of I potet & Policy Bifondic \\
\hline 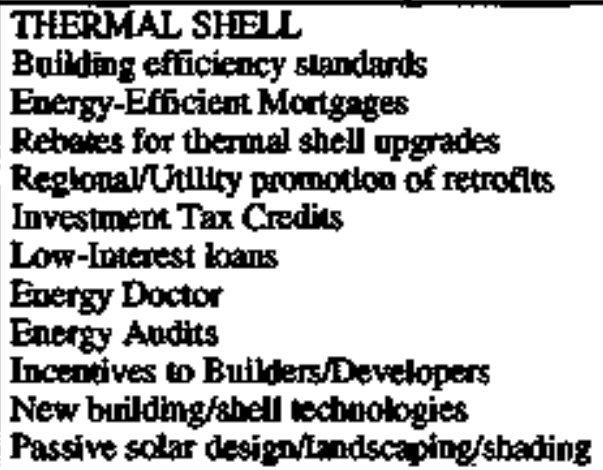 & $\begin{array}{l}\text { Set "Legal Availability" of specific shells } \\
\text { Decision model of thernal shell investments } \\
\text { Adjust cost of specific sthell components } \\
\text { Change rates of thermat shell reirofits } \\
\text { Decision model for retrofits } \\
\text { Adjust purctase cost of thermal shells } \\
\text { Add shell components and options } \\
\text { Add thermal shell specificatioas }\end{array}$ \\
\hline 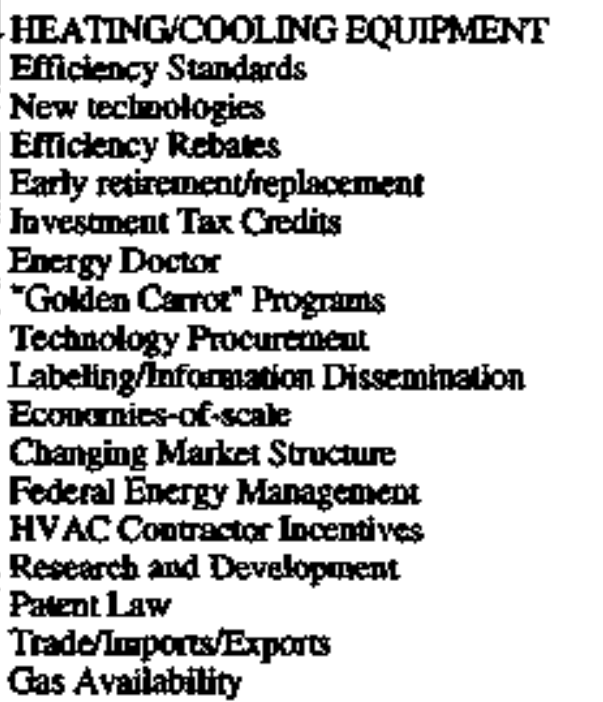 & 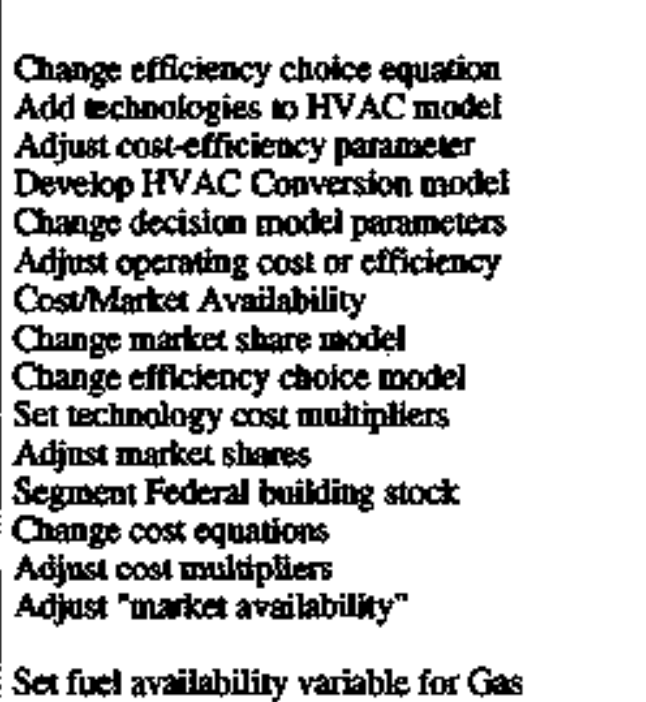 \\
\hline $\begin{array}{l}\text { DISTRIBUTION SYSTEMS } \\
\text { Efficiency Standarts } \\
\text { New techologies } \\
\text { Eficiency Rebates } \\
\text { Early retiremendreplacement }\end{array}$ & $\begin{array}{l}\text { Configure new distribution systems } \\
\text { Change distriburtion system cost } \\
\text { Conversion of distribution systims }\end{array}$ \\
\hline $\begin{array}{l}\text { ENERGY PRTCES } \\
\text { Taxes } \\
\text { entrgy taxes } \\
\text { carbon tax }\end{array}$ & Ohenge fuel prices in desired years \\
\hline
\end{tabular}


This analysis employs the multiple-attribute approach in order to lend a better physical interpretation to the model and to facilitate a more disaggregated analysis of themn] shell efficiency investments. In this section, we describe the methodology used to develop the themal shell data and bnilding prototypes for the two regions. Section 3.1 describes the themal shell attributes and the components they represent in our analysis. In Section 3.2, we provide data on the building dimensions for the varions housing types and the manner in which they are used as weighting factors in calculating the whole-building heating and cooling loads. In Section 3.3, we use combinations of the attributes to define a set of thermal shell packages representing the housing stock of each region. Section 3.3 also develops the market shares of these shell packages for existing and new homes of each housing type and shell group. In Section 3.4, we detail our estimates of the purchase price for shell attributes in new construction. These price estimates are designed to be used in decisions about thermal shell purchases as a means of comparing the econoric tradeoffs between higher purchase price and lower operating cost dne to lower heating and/or cooling requirements.

\subsection{Thermsl Shell Components}

We use six components in this analysis to represent the thermal shells. The physical characteristics of each component are used to specify thermal integrity levels. Table 3.1 lists the levels of each component and their U-values, along with shading coefficients for windows. These components correspond to specific attributes in the REEPS modeling framework and are used to deternine the heat gain and loss characteristics of each thermal shell package. The South prototypes have a slab foundation because this is the predominant fonndation design in that region. The foundation attribute levels for the South in Table 3.1 refer to the thickness and depth of insulation applied to the slab. In the north, the predominant foundation is an unheated basement, for which the foundation attribute levels in Table 3.1 refer to basement (underfloor) insulation. The attribute levels for ceilings and walls refer to insulation R-values. The infiltration levels are based on the number of Air Changes per Hour (ACH). For windows, we use seven window types, ranging from single-glazed windows to superwindows, and assume a wood frame is used for all types. The last four of these window types represent new technologies that have appeared on the market in the past 5-10 years and are expected to gain market share as their purchase price declines with increasing production volumes (Frost et al. 1993). The residual loads are used to represent heating and cooling load effects (such as internal gains) not attributed to the shell components.

We use building energy simulations to determine the heating and cooling loads associated with the various themal shells. Building energy simulations require weather input data for specific cities. We used a popalation-weighted climate-averaging program (Andersson et al. 1986) to detemine the most representative weather conditions for each region. The weather of Chicago, IL was found to approximate the weather of the northern region while the weather of Charleston, SC approximates the weather for the southern region. We bave estimated the thermal shell heating and cooling loads using normalized component loads adopted from a database of DOE-2 thermal simulation model runs (Huang et al 1987a). The simulations assumed a constant thermostat setpoint of $70^{\circ} \mathrm{F}$ for heating (without themostat sethack at night) and $78^{\circ} \mathrm{F}$ for cooling, and included typical intemal gains. Appendix A gives the normalized component loads for the North and South regions.

We use the shell components in Table 3.1 as specific attributes in the thermal shell framework of the REEPS HVAC module. Building loads are calculated directly from the nomalized component loads for heating and cooling. For a given level of an attribute, such as R-7 insulation for ceilings, the nomalized component loads give the heating and cooling loads in kBtu per square foot of ceiling per year. 


\begin{tabular}{|c|c|c|c|}
\hline Compoent & Construction & U-Vider $\mathbf{S C}$ & Construction Assupiptions \\
\hline Coiling & $\begin{array}{l}\mathrm{ROC} \\
\mathrm{ROO} \\
\mathrm{R} 11 \\
\mathrm{R} 19 \\
\mathrm{R} 22 \\
\mathrm{R} 30 \\
\mathrm{R} 38 \\
\mathrm{R} 49 \\
\mathrm{R} 60\end{array}$ & $\begin{array}{l}0.2470 \\
0.0928 \\
0.0682 \\
0.0460 \\
0.0389 \\
0.0293 \\
0.0235 \\
0.0185 \\
0.0152 \\
\end{array}$ & $\begin{array}{l}\text { Uninsulated ceiling below attic } \\
\text { R07 insolated ceiling below atic } \\
\text { R11 insolated ceiling below atic } \\
\text { R19 insulated ceiling below attic } \\
\text { R22 insolated ceiling below atic } \\
\text { R30 insulated ceiling below attic } \\
\text { R38 insulated celling below attic } \\
\text { R49 insulated ceiling below atric } \\
\text { R60 insulaned ceiling below attic }\end{array}$ \\
\hline Wall & $\begin{array}{l}\mathrm{R} 10 \\
\mathrm{RO7} \\
\mathrm{R} 11 \\
\mathrm{R} 13 \\
\mathrm{R} 19 \\
\mathrm{R} 27 \\
\mathrm{R} 34\end{array}$ & $\begin{array}{l}0.2241 \\
0.1051 \\
0.0881 \\
0.0693 \\
0.0600 \\
0.0427 \\
0.032\end{array}$ & $\begin{array}{l}\text { Uningulated } 2 \times 4 \text { wood frame wall } \\
\text { R07 insulated } 2 \times 4 \text { wood frame wall } \\
\text { R11 tnsulated } 2 \times 4 \text { wood frame wall } \\
\text { R13 insulated } 2 \times 4 \text { wood frame wall } \\
\text { R19 insulated } 2 \times 6 \text { wood frame wall } \\
\text { R19 insulated } 2 \times 6 \text { wood frame wall with insulated sheathing } \\
\text { R19 insulated } 2 \times 6 \text { wood frame wall with insulated sheathing }\end{array}$ \\
\hline Windows & \begin{tabular}{|l}
$1.0-$ gla \\
2.0-gla \\
3.0-gla \\
2-gla loE \\
2-gla kEAr \\
Spectrally \$eL \\
Superwitow \\
Heat Mimor
\end{tabular} & $\begin{array}{ll}1.10 & 0.90 \\
0.48 & 0.66 \\
0.30 & 0.61 \\
0.36 & 0.59 \\
0.30 & 0.39 \\
0.36 & 0.44 \\
0.20 & 0.51 \\
0.29 & 0.39\end{array}$ & 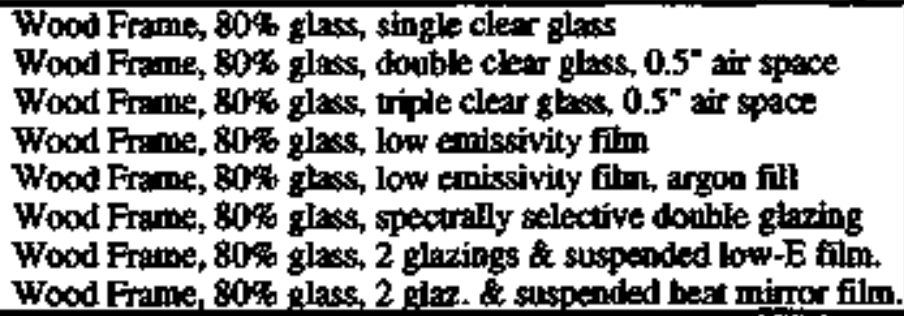 \\
\hline $\begin{array}{l}\text { Floors } \\
\text { (crawl or } \\
\text { mbetifed } \\
\text { basement) }\end{array}$ & $\begin{array}{l}\text { R00 } \\
\text { R11 } \\
\text { R19 } \\
\text { R30 } \\
\text { R38 } \\
\text { R49 }\end{array}$ & $\begin{array}{l}0.2137 \\
0.0693 \\
0.0471 \\
0.0328 \\
0.0295 \\
0.0201\end{array}$ & 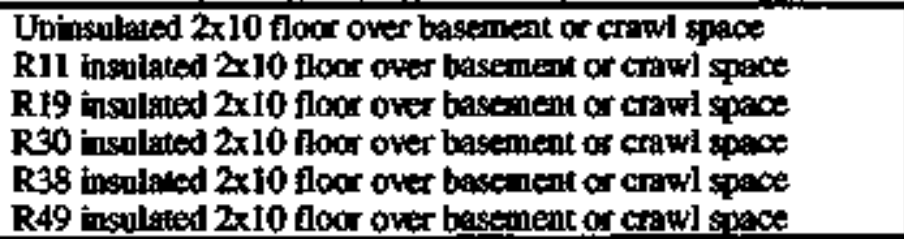 \\
\hline Slab & \begin{tabular}{|l}
$R-0$ \\
$R-52 \pi t$ \\
$R-102 f t$ \\
$R-54 f t$ \\
$R-104 f t$
\end{tabular} & $\begin{array}{l}0.4752 \\
0.2505 \\
0.2107 \\
0.1983 \\
0.1380\end{array}$ & 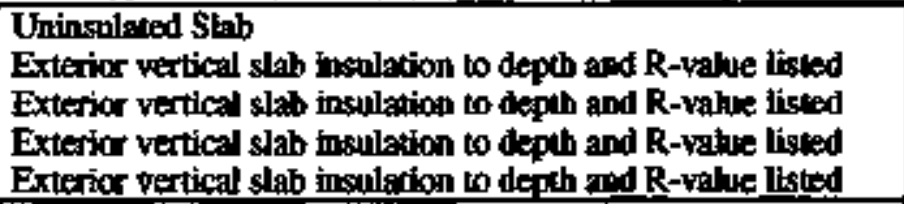 \\
\hline $\begin{array}{l}\text { Healed } \\
\text { Basement }\end{array}$ & \begin{tabular}{|l} 
R-0 \\
R-5 4ft \\
R-10 4ft \\
R-5 8ft \\
R-10 8ft
\end{tabular} & $\begin{array}{l}1.6717 \\
0.8348 \\
0.6734 \\
0.6655 \\
0.4468\end{array}$ & 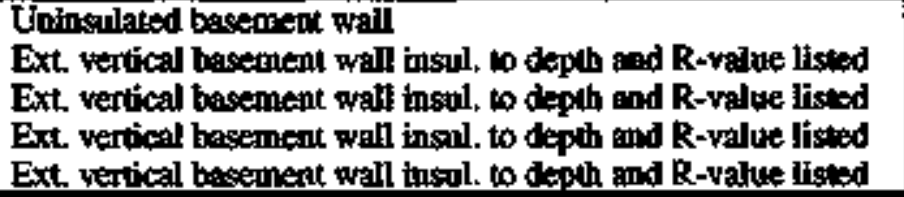 \\
\hline \multicolumn{4}{|c|}{ 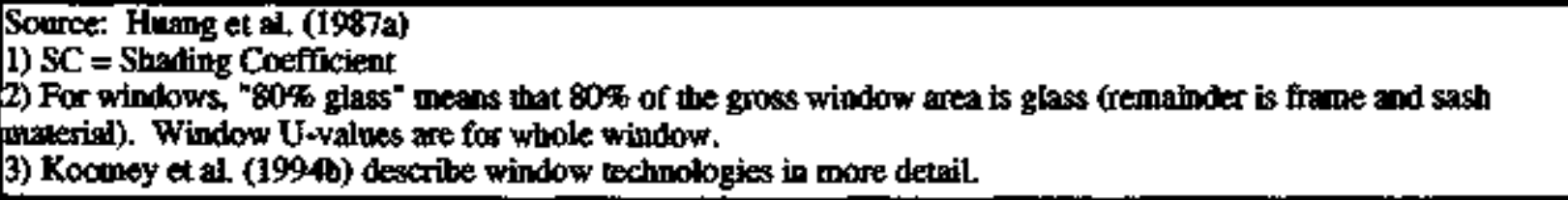 } \\
\hline
\end{tabular}

One should note that our approach to calculating building loads differs from the approach suggested in the REEPS model documentation. ${ }^{3}$ The suggested methodology is based on the

3 See pages HV-9-12 in the REEPS User's guide (EPRI 1990) for a more detailed description of this methodology, besed od the Manual I method of calcolating heat gains and losses. The Magual J method (ACCA 1975) develops a whole-house U-valwe by weraging the component U-values using componeat weights (component areas modified to account for tron-conductive heal transfer). This metbod is similar wo the equipment sizing method presented by ASHRAE (1993). The Manual J method is less accurate then bnilding simulations because if does not explicitly accounl for complex pheoromene such as radiative transfer or thermal mass. 
Manual I method (ACCA 1975) which estimates boilding loads based on a whole-house weighted average U-value. On the other hand, the DOE-2 building simulation model, from which we derived the normalized loads, can incorporate physical interactions that the imputed weights cannot. By using an explicit physical specification of the building components, building simulations achieve a better representation of the heating and cooling characteristics than approaches which rely on an index of thermal integrity or a whole house U-value (Johnson and Hanford 1992). The use of specific attributes and building components is also important in analyzing the economics of consumer decisions abont thermal shells.

\subsection{Building Characteristics}

We developed a set of data on the dimensions of buildings for each of the two regions and each of the four housing types: small single-family, large single-family, multifamily and manufactured homes, as given in Table 3.2. These building dimensions determine the shell component weighting factors described in the previons section.

\begin{tabular}{|c|c|c|c|c|c|c|c|c|}
\hline \multirow[b]{2}{*}{ Howsing Type: } & \multicolumn{4}{|c|}{ North RejJon } & \multicolumn{4}{|c|}{ Sauth Region } \\
\hline & $\begin{array}{l}\text { Smaly } \\
\text { Single- } \\
\text { Fanily }\end{array}$ & $\begin{array}{l}\text { Lange } \\
\text { Single- } \\
\text { Family }\end{array}$ & $\begin{array}{l}\text { Malti- } \\
\text { farmily }\end{array}$ & $\begin{array}{c}\text { Manu- } \\
\text { tactured } \\
\text { Homes }\end{array}$ & $\begin{array}{l}\text { Sinall } \\
\text { Single- } \\
\text { Franily }\end{array}$ & $\begin{array}{l}\text { Large } \\
\text { Single- } \\
\text { Fanily }\end{array}$ & $\begin{array}{l}\text { Multi- } \\
\text { fanily }\end{array}$ & $\begin{array}{l}\text { Manu- } \\
\text { factured } \\
\text { Homes }\end{array}$ \\
\hline \multirow{2}{*}{$\begin{array}{l}\text { Number of Stories } \\
\text { Foundation Type }\end{array}$} & 1 & 2 & 1 & 1 & $\mathbf{I}$ & 1 & 1 & 1 \\
\hline & \multicolumn{4}{|c|}{ Unbeated Basement } & \multicolumn{4}{|c|}{ Slab } \\
\hline \multicolumn{9}{|c|}{ Component Dinensions (satware fet) } \\
\hline $\begin{array}{l}\text { Conditioned Floor Anea } \\
\text { Ceiling } \\
\text { Walls } \\
\text { Wirdows } \\
\text { Infiltration } \\
\text { Foindation Area . } \\
\text { Foundation Perim. (in. ft) } \\
\end{array}$ & $\begin{array}{l}1227 \\
1227 \\
1002 \\
147 \\
1227 \\
1227 \\
144 \\
\end{array}$ & $\begin{array}{l}2892 \\
1446 \\
2349 \\
347 \\
2892 \\
1446 \\
169 \\
\end{array}$ & $\begin{array}{c}1074 \\
479 \\
476 \\
73 \\
1074 \\
31\end{array}$ & $\begin{array}{l}1207 \\
1207 \\
993 \\
145 \\
1207 \\
1207 \\
142 \\
\end{array}$ & $\begin{array}{l}1336 \\
1336 \\
1051 \\
160 \\
1336 \\
1336 \\
151 \\
\end{array}$ & $\begin{array}{l}2562 \\
2562 \\
1785 \\
307 \\
2562 \\
2562 \\
262 \\
\end{array}$ & $\begin{array}{l}1056 \\
490 \\
480 \\
48 \\
1056 \\
31\end{array}$ & $\begin{array}{l}1195 \\
1195 \\
987 \\
143 \\
1195 \\
1195 \\
141 \\
\end{array}$ \\
\hline 1990 Stock (nillions) & 23.6 & 10.6 & 15.1 & 2.5 & 19.1 & 7.1 & 9.5 & 3.7 \\
\hline \multicolumn{9}{|c|}{ 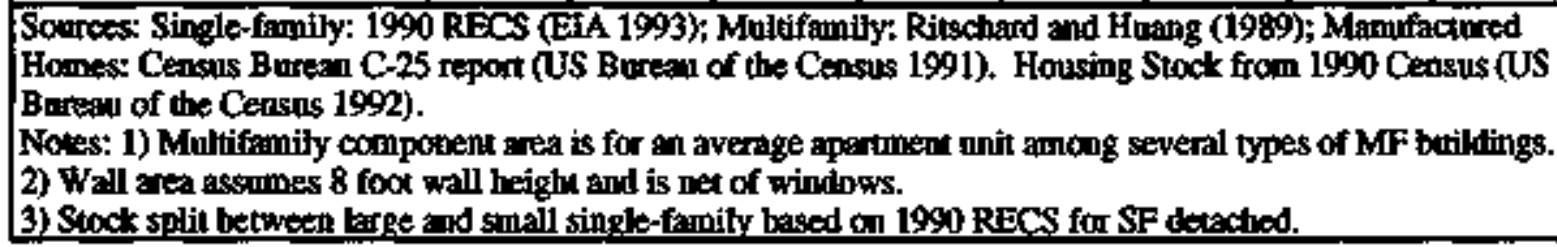 } \\
\hline
\end{tabular}

Note that REEPS does not distinguish between stock homes and new construction based on building dimensions. Rather, the vintage of buildings is distinguished by thermal integrity level, which is specified through the shell pactage market shares described in Section 3.3. We have used floor areas for new homes, because floor area mainly affects the new-home decision models. This will not bias the calculation of energy usage for existing homes in REEPS bectuse the usage equation for existing homes is calibrated to the existing-home UECs at the beginning of forecast execution. For small single-family, a 1-story home is used in both north and south regions. For large single-family, a 2-story horne is used in the north while a one-story home is used in the south, according to the predominant type in each region. The heated floor areas for small single-family and large single-family homes were derived from the 1990 RECS based on the average above-grade (excluding basements) heated floor area for single-family homes below and above 1800 square feet, respectively. These data are averages for homes in the RECS sample built between 1980 and 1990 . For multifamily buildings, the dimensions are averaged across several different configurations of apartment units because the location of a unit within the 
building is important in determining the apartment-unit load (Ritschard and Huang 1989). Generally, the apartment buildings we modeled are between 2 and 4 stories, with a combination of middle and end units. Marufactured home dimensions are based on average floor areas for new mobile homes shipped in 1990 (US Bureau of the Census 1991), and a width of 28 feet, which is a common truss width.

The heating and cooling loads for a given set of attributes (constituting a single prototype) are linear functions of the component loads and are scaled by weighting factors based on the building dimensions:

$$
\text { Load }(M M B t w)=\sum{ }_{i}\left(W_{i} * N_{i}\right)+\text { Residual Load }
$$

$W_{i}$ is the weighting of component $i$ and $N L_{i}$ is the nomalized heating or cooling load for component $i$. For infiltration, the weight is the total above-grade conditioned or heated floor area. For slab foundations, the weight is the perimeter of the slab. For all other components, the weight is sineply the area in square feet of the component.

\subsection{Thermal Shell Packnges}

Having defined the shell component attributes and weighting factors, we now build a set of prototypes for each negion by choosing "packages" of the components which are representative of housing practices in each region. These prototypes can then be used to describe the composition of the existing housing stock and the expected composition in new housing construction. These packages determine the design usage of space conditioning equipment based on a given package's heating and cooling loads calculated using Eqaation 3.1. We choose a total of twelve such packages for each region, ranging from completely uninsulated to extremely wellinsulated homes with component levels that are currently available on the market.

Tables 3.3-N and 3.3-S list the thermal shell packages for the north and south regions, respectively, listed in order of increasing thermal integnity and thus decreasing heat load. The main differences between the packages are their ceiling and wall insulation, which generally have the largest effect on overall heating and cooling loads. Rather than defining all possible combinations, which would result in unnecessary proliferation of shell packages, we have chosen this limited set of packages to represent the distribution of themal integrity in each region. The packages are selected sensibly, in that we do not pair high levels of ceiling insulation with tow levels of wall insulation, for example. We use packages 1-8 in each region to describe existing homes and packages 3-9 to describe new homes. Packages 10-12 are intended as the high-end options for thermal shell choices in future years. The packages are generally the same for both regions, with the following exceptions. First, since the foundations are different in the north and south prototypes, the foundation insulation levels in the packages differ somewhat. Second, we chose Superwindows for packages $10-12$ in the north to minimize heat loss while the same packages in the south include Heat Mirrors to minimize solar gain. Finally, the insulation levels are higher in some packages in the north than in the south as might be expected due to the differences in heating requirements and as current practice snggests (NAHB 1989).

To develop the market shares of these thermal shells in the existing housing stock, we used the 1990 RECS along with estimates of prototype populations for single-family homes (Ritschard et al. 1992), multifamily homes (Ritschard and Huang 1989) and manufactured homes (Koomey et al. 1991a). The RECS data allowed os to break out small and large single-family homes and to assess insulation categories and windows for the four housing types. We followed a similar procedure in developing the market shares for new homes, but based our analysis on the subset 
of homes in the 1990 RECS which were built in the 1980s. We included estimates of current construction practice for each housing type (Hanford et al. 1994) where market share data for a given shell package were missing or inadequate. The resulting market share data are shown in Tables 3.4-N and 3.4-S for existing homes and Tables 3.5-N and 3.5-S for new homes.

\begin{tabular}{|c|c|c|c|c|c|}
\hline \multirow[b]{2}{*}{ Package } & \multicolumn{5}{|c|}{ Conproment } \\
\hline & Celing & Walls & Wladows & $\begin{array}{l}\text { Inilitration } \\
\text { (ACH) }\end{array}$ & $\begin{array}{l}\text { Foundation } \\
\text { (Uinlented } \\
\text { Brsenenes) }\end{array}$ \\
\hline$\overline{1}$ & $\overline{\mathbf{R}-0}$ & $\overline{R-0}$ & I-G & 08 & $\mathrm{R}-0$ \\
\hline 2 & R-7 & $\mathbf{R}-\mathbf{0}$ & $1-G$ & 0.7 & $\mathrm{R}-0$ \\
\hline 3 & R-11 & R-7 & $1-G$ & 0.7 & $\mathbf{R}-\mathbf{0}$ \\
\hline 4 & R-19 & R-7 & 20 & 0.55 & R-11 \\
\hline 5 & R-22 & R-11 & $2-G$ & 0.55 & R-11 \\
\hline 6 & $R=30$ & R-13 & $2-G$ & 0.55 & R-11 \\
\hline 7 & R-30 & R-13 & 2GLEA & 0.55 & R-11 \\
\hline 8 & R-33 & $\mathbf{R}-19$ & 2GLAA & 0.4 & R-11 \\
\hline 9 & $R-49$ & R.19 & 2GEA & 04 & R-19 \\
\hline 10 & R-38 & R-19 & Superwindow & 0.4 & R.19 \\
\hline 11 & $R-49$ & R-27 & Soperwindow & 0.4 & R-19 \\
\hline 12 & $R-60$ & $R-34$ & Soperwindaw & 0.4 & R-30 \\
\hline
\end{tabular}

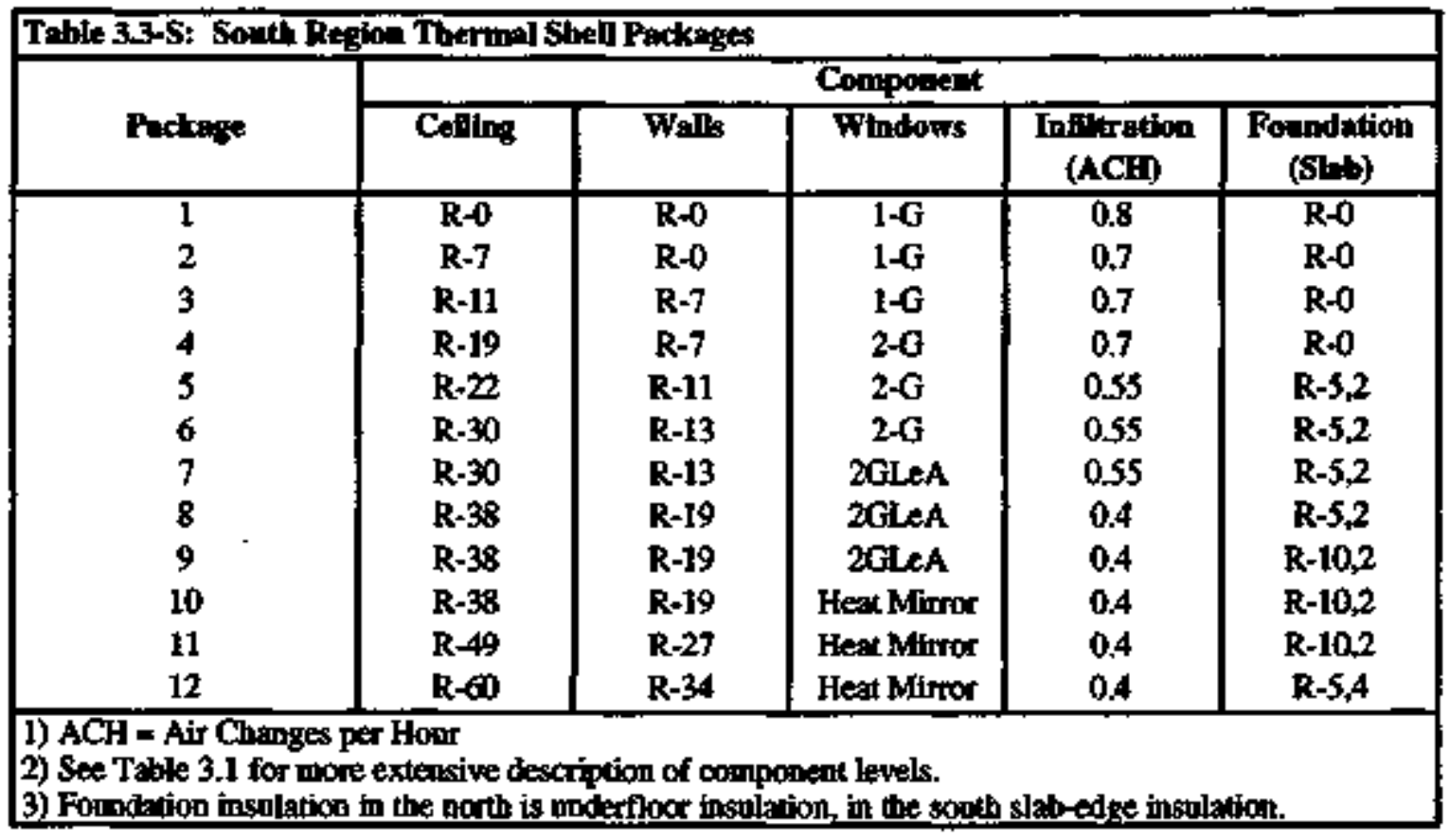

REEPS allows the user to group thermal shells into "shell groups" for the purpose of defining thermal shell market shares. These shell groups are differentiated by HVAC equipment type, thus one or more HVAC systems are assigned to each shell group. One could specify a distinct thermal shell group for each HVAC system, but this would needlessly repeat heating/cooling profiles which are already quite similar. We separated single-family homes into five shell group categories based on heating and/or cooling system: Heat Pumps, Electric Heating, Gas Fumace/Central Air, Fuels, and Other. 


\begin{tabular}{|c|c|c|c|c|c|c|c|c|c|c|c|c|}
\hline \multicolumn{6}{|c|}{ 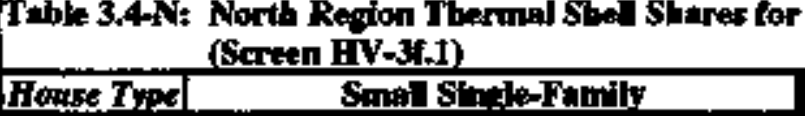 } & \multicolumn{5}{|c|}{ 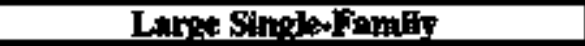 } & \multirow{2}{*}{$\frac{\mathbf{M F}}{\mathbf{A}}$} & \multirow{2}{*}{$\frac{\text { Mi }}{A \|}$} \\
\hline Shell Oras & FP & Eve & $\mathrm{NGKCA}$ & Funels & Other & HP & Eloc & $\mathrm{NGACA}$ & Fonets & Dthar & & \\
\hline $\begin{array}{c}\text { Pactage } \\
1 \\
2 \\
3 \\
4 \\
5 \\
6 \\
7 \\
8 \\
9 \\
10 \\
11 \\
12\end{array}$ & $\begin{array}{l}4 \% \\
3 \% \\
14 \% \\
24 \% \\
26 \% \\
26 \% \\
3 \%\end{array}$ & $\begin{array}{l}3 \% \\
6 \% \\
14 \% \\
56 \% \\
11 \% \\
8 \% \\
2 \%\end{array}$ & $\begin{array}{l}7 \% \\
9 \% \\
34 \% \\
41 \% \\
3 \% \\
5 \%\end{array}$ & $\begin{array}{l}0.3 \% \\
20 \% \\
7 \% \\
37 \% \\
32 \% \\
3 \% \\
2 \%\end{array}$ & $\begin{array}{l}14 \% \\
5 \% \\
22 \% \\
45 \% \\
5 \% \\
9 \%\end{array}$ & $\begin{array}{l}8 \% \\
32 \% \\
43 \% \\
5 \% \\
11 \%\end{array}$ & $\begin{array}{l}11 \% \\
11 \% \\
22 \% \\
48 \% \\
4 \% \\
4 \%\end{array}$ & $\begin{array}{l}8 \% \\
3 \% \\
31 \% \\
36 \% \\
4 \% \\
17 \% \\
2 \%\end{array}$ & $\begin{array}{c}1 \% \\
20 \% \\
6 \% \\
29 \% \\
42 \% \\
1 \% \\
1 \%\end{array}$ & $\begin{array}{l}6 \% \\
3 \% \\
29 \% \\
32 \% \\
9 \% \\
10 \% \\
10 \%\end{array}$ & $\begin{array}{l}36 \% \\
36 \% \\
25 \% \\
4 \%\end{array}$ & $\begin{array}{l}20 \% \\
7 \% \\
24 \% \\
29 \% \\
20 \%\end{array}$ \\
\hline Total & $100 \%$ & $100 \%$ & $100 \%$ & $100 \%$ & $100 \%$ & $100 \%$ & $100 \%$ & $100 \%$ & $100 \%$ & $100 \%$ & $100 \%$ & $100 \%$ \\
\hline $\begin{array}{l}1990 \text { Stodk } \\
\text { (thonsmats) }\end{array}$ & 563 & 2,510 & 4,621 & 13,078 & 3,328 & 203 & 673 & 2,698 & 5,588 & 839 & 13,906 & 2,845 \\
\hline
\end{tabular}

\begin{tabular}{|c|c|c|c|c|c|c|c|c|c|c|c|c|}
\hline \multicolumn{13}{|c|}{ 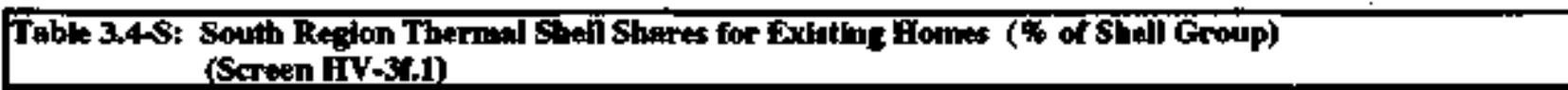 } \\
\hline Howse Type & \multicolumn{5}{|c|}{ Smidl Sin:qe-Fanily } & \multicolumn{5}{|c|}{ Lorze Single-Family } & \multirow{2}{*}{ MF } & \multirow{2}{*}{$\frac{\text { MF }}{\text { Al }}$} \\
\hline Shell Gromp & HP & Elec & NG/CA & Fuels & Other & HP & Dlee & NG/CA & Fuels & Other & & \\
\hline $\begin{array}{c}\text { Pactrage } \\
1 \\
2 \\
3 \\
4 \\
5 \\
6 \\
7 \\
8 \\
9 \\
10 \\
11 \\
12\end{array}$ & $\begin{array}{l}2 \% \\
7 \% \\
15 \% \\
1 \% \\
52 \% \\
18 \% \\
6 \%\end{array}$ & $\begin{array}{l}12 \% \\
11 \% \\
13 \% \\
11 \% \\
39 \% \\
14 \%\end{array}$ & $\begin{array}{l}8 \% \\
3 \% \\
26 \% \\
6 \% \\
42 \% \\
9 \% \\
7 \%\end{array}$ & $\begin{array}{l}12 \% \\
8 \% \\
32 \% \\
8 \% \\
37 \% \\
3 \%\end{array}$ & $\begin{array}{l}7 \% \\
6 \% \\
8 \% \\
8 \% \\
40 \% \\
25 \% \\
5 \%\end{array}$ & $\begin{array}{l}25 \% \\
7 \% \\
29 \% \\
16 \% \\
18 \% \\
6 \%\end{array}$ & $\begin{array}{c}10 \% \\
15 \% \\
10 \% \\
60 \% \\
6 \%\end{array}$ & $\begin{array}{l}4 \% \\
5 \% \\
24 \% \\
5 \% \\
37 \% \\
10 \% \\
15 \% \\
1 \%\end{array}$ & $\begin{array}{l}5 \% \\
20 \% \\
40 \% \\
0 \% \\
22 \% \\
0 \% \\
13 \%\end{array}$ & $\begin{array}{c}14 \% \\
38 \% \\
5 \% \\
42 \%\end{array}$ & $\begin{array}{l}7 \% \\
41 \% \\
44 \% \\
9 \%\end{array}$ & $\begin{array}{l}5 \% \\
28 \% \\
68 \%\end{array}$ \\
\hline Total & $100 \%$ & $100 \%$ & $100 \%$ & $100 \%$ & $100 \%$ & $100 \%$ & $100 \%$ & $100 \%$ & $100 \%$ & 1000 & $100 \%$ & $100 \%$ \\
\hline losos Stock & 2,533 & 3,435 & 4,759 & 8,660 & 3,256 & 1,131 & 1,163 & 3,136 & 1,586 & 603 & 10,510 & 2,366 \\
\hline $\begin{array}{l}\text { (1) MF = Mu } \\
\text { (2) } \mathrm{HP}=\mathrm{He} \\
\mathrm{LPG} \text { and Mis } \\
\text { (3) Soures: }\end{array}$ & fomi & $\mathbf{M H}=$ & anufact & $\mathrm{dHO}$ & & & & & & & & \\
\hline
\end{tabular}

We estimated only one distribution for multifamily homes and one for manufactured homes, since these house types have less variation in thermal integrity and make up a less significant fraction of the housing stock. This breakout capurres the effect of differences in the vintage of homes and equipment between the groups, and similarities in the economic characteristics of heating/cooling within each group. The "Heat Pump" shell group represents only those homes whose main heating systems are heat punps. The "Electric" shell group includes homes heated by built-in (baseboard-type) electric units or by central electric furnaces. The "Gas Fumace/Central Air" shell group includes only those homes with central gas warm-gir fumaces 
and central air conditioning. The "Fuels" shell group includes homes heated by gas and oil technologies other than centrally ait-conditioned homes with natural gas fumaces. The "Other" shell group includes homes heated with LFG or with miscellaneous fuels such as wood, coal or kerosene. In this segmentation, bomes with LPG heating are included in the Other shell group because we wanted to separate natural gas and LPG-heated homes to account for piped-gas availability, and LPG homes tend to be rural and therefore more similar to the homes with Other fuels (kerosene, wood, etc.). The breakout of the Heat Punp and Gas FurnaceKAC shell groups is significant because these two options predominate in current construction, together accounting for over half of all HVAC systems in 1990 (US Bureau of the Census 1991).

\begin{tabular}{|c|c|c|c|c|c|c|c|c|c|c|c|c|}
\hline Table 3.5-N & $\begin{array}{l}\text { North } \\
\text { (Scree }\end{array}$ & $\begin{array}{l}\text { egonan } \\
\text { HV.4e }\end{array}$ & Theraid & She & 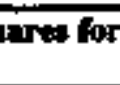 & New 1 & anes (\% & 5 of Sh & Sroa & & & \\
\hline Borse $T_{y j o}$ & & Sn: & Sinqled & intily & & & Ertge & Sinde-F & $\operatorname{lng} 14 y$ & & MiF & MF \\
\hline Sheil Grape & $\mathbf{E P}$ & Elec & NGACA & Fouls & Other & EP & Elet & NGFA & Futs's & Other & AD & All \\
\hline $\begin{array}{c}\text { Package } \\
1 \\
2 \\
3 \\
4 \\
5 \\
6 \\
7 \\
8 \\
9 \\
10 \\
11 \\
12 \\
\end{array}$ & $\begin{array}{r}5.1 \% \\
0.0 \% \\
0.0 \% \\
79.9 \% \\
0.0 \% \\
15.1 \%\end{array}$ & $\begin{array}{r}9.8 \% \\
0.0 \% \\
3.7 \% \\
53.5 \% \\
0.0 \% \\
33.0 \%\end{array}$ & $\begin{array}{r}5.2 \% \\
0.0 \% \\
62.8 \% \\
0.0 \% \\
32.1 \%\end{array}$ & $\begin{array}{r}1.5 \% \\
0.0 \% \\
15.9 \% \\
44.8 \% \\
0.0 \% \\
37.8 \%\end{array}$ & $\begin{array}{r}1.7 \% \\
0.0 \% \\
0.0 \% \\
66.6 \% \\
0.0 \% \\
31.7 \%\end{array}$ & $\begin{array}{r}15.5 \% \\
0.0 \% \\
75.3 \% \\
0.0 \% \\
9.1 \%\end{array}$ & $100.0 \%$ & $\begin{array}{r}2.6 \% \\
0.0 \% \\
0.0 \% \\
49.0 \% \\
0.0 \% \\
48.4 \%\end{array}$ & $\begin{array}{r}5.5 \% \\
0.0 \% \\
0.0 \% \\
67.6 \% \\
0.0 \% \\
26.9 \%\end{array}$ & $\begin{array}{r}15.5 \% \\
0.0 \% \\
84.5 \%\end{array}$ & $\begin{array}{r}19.6 \% \\
5.3 \% \\
7.0 \% \\
68.1 \%\end{array}$ & $\begin{array}{r}11.4 \% \\
2.3 \% \\
17.6 \% \\
62.9 \% \\
0.0 \% \\
5.7 \%\end{array}$ \\
\hline Total & $100 \%$ & $100 \%$ & $100 \%$ & $100 \%$ & $100 \%$ & $100 \%$ & $100 \%$ & $100 \%$ & $100 \%$ & $100 \%$ & 1006 & $100 \%$ \\
\hline
\end{tabular}

\begin{tabular}{|c|c|c|c|c|c|c|c|c|c|c|c|c|}
\hline \multirow{2}{*}{\multicolumn{6}{|c|}{ 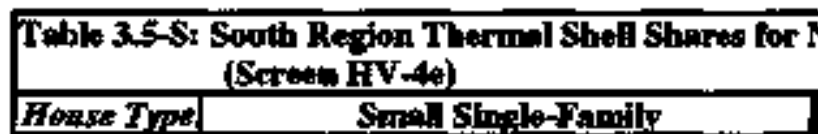 }} & 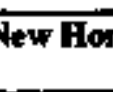 & $5(\%$ & of Sheil & 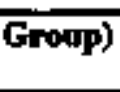 & & \multirow{3}{*}{$\frac{\mathrm{MF}}{\mathrm{Al}}$} & \multirow{3}{*}{$\frac{\mathrm{MH}}{\mathrm{A}}$} \\
\hline & & & & & & \multicolumn{5}{|c|}{ Lenge Sin:de-Family } & & \\
\hline Shod Groed & HP & Elec & $\mathrm{NGCA}$ & Feds & Other & FiP & Elec & $\mathrm{NG} / \mathrm{CA}$ & Foels & Otrer & & \\
\hline $\begin{array}{c}\text { Pactage } \\
1 \\
2 \\
3 \\
4 \\
5 \\
6 \\
7 \\
8 \\
9 \\
10 \\
11 \\
12\end{array}$ & $\begin{array}{r}25.7 \% \\
2.7 \% \\
54.6 \% \\
17.0 \%\end{array}$ & $\begin{array}{l}59.0 \% \\
0.0 \% \\
22.1 \% \\
18.8 \%\end{array}$ & $\begin{array}{r}22.3 \% \\
0.0 \% \\
23.4 \% \\
54.3 \%\end{array}$ & $\begin{array}{r}34.6 \% \\
0.0 \% \\
17.2 \% \\
48.2 \%\end{array}$ & $\begin{array}{r}21.4 \% \\
0.0 \% \\
4.3 \% \\
74.3 \%\end{array}$ & $\begin{array}{r}15.5 \% \\
0.0 \% \\
66.1 \% \\
18.4 \%\end{array}$ & $\begin{array}{r}74.0 \% \\
0.0 \% \\
0.0 \% \\
26.0 \%\end{array}$ & $\begin{array}{r}18.4 \% \\
0.0 \% \\
14.2 \% \\
67.4 \%\end{array}$ & $100.0 \%$ & $\begin{array}{r}11.2 \% \\
0.0 \% \\
28.2 \% \\
60.6 \%\end{array}$ & $\begin{array}{r}82.6 \% \\
0.0 \% \\
9.6 \% \\
7.8 \%\end{array}$ & $\begin{array}{l}44.7 \% \\
44.0 \% \\
11.3 \%\end{array}$ \\
\hline Total & $100 \%$ & $100 \%$ & $100 \%$ & $100 \%$ & $100 \%$ & $100 \%$ & $101 \%$ & $100 \%$ & $100 \%$ & $100 \%$ & 1008 & $100 \%$ \\
\hline $\begin{array}{l}\mathrm{MF}=1 \\
\mathrm{HP}=\mathrm{I} \\
\mathrm{G} \text { and }\end{array}$ & $\mathrm{am}$ & $\overline{\mathrm{MH}}$ & and: & & & & & & & & & \\
\hline
\end{tabular}

The shell group market shares in Tables 3.5-N\&S are bimodal or discontinuous for certain shell groups, which may be due to several factors. First, the thermal integrity of new residential 
construction may in reality exhibit a bimodal distribution becaltse the market is segmented into low-end "builder" homes and high-quality "custom" homes. Second, due to the discrete nature of the REEPS shell packages and the RECS thermal shell variables, it is possible to have significant changes in shell package assignment with only a small change in the RECS value. This is exacerbated by the fact that the RECS variables for insulation and window characteristics do not allow one to precisely detemine the insulation value of these shell components (i.e., the discrete variables have few possible values). Finally, in some cases, such as large single-family fuelheated homes in the South, the RECS 1980-1990 vintage sample size is very small, leading to discontinuous distributions (or all sample points in ore shell package). The problem of small sample sizes should not affect the aggregate forecast results, however, becanse these house types represent a very small part of the new building stock.

\subsection{New Home Thermal Shell Prices}

The purchase prices of thermal shell components are required in the REEPS model to quantify the economic choices consumers face when selecting the thermal integrity level for a new home. We estimated these prices from a regional database of conservation measure prices for new single-family buildings (Koomey et al. 1991b) and data on window prices for emerging technologies (Koomey et al. 1994b). The REEPS model requires these prices to be specified per square foot of floor area, thus we have normalized all prices using building dimensions for new two-story and one-story homes, with the resulting estimates shown in Table 3.6. The prices also account for regional price differences, as reported in Koomey et al. (1991b).

We do not present prices for existing home thermal shell retrofits because REEPS allows only one set of thermal shell prices. When the thermal shell retrofit module is activated in REEPS, the model uses new home component prices to model the price of shell retrofits. REEPS also constrains thermal shell prices to be constant for all housing types. In new construction, we believe that this is a reasonably accurate portrayal of the market. For shell retrofits, however, prices can vary substantially between housing types, leading to potentially inaccurate modeling of thermal shell retrofit decisions. It is not possible to overcome these limitations without changing the REEPS computer code.

\section{EQUIPMENT DATA AND MARKET SHARES}

The REEPS HVAC model pemits the user to define and configure equipment and distribution systems for the space conditioning end-uses. The equipment modeling structure is quite general and can apply to any type of heating and/or cooling equipment, such as heat pumps or natural gas fumaces. The user may define as many equipment technologies as appropriate by specifying each equipment type's technical characteristics such as the fuel used, equipment lifetime, size or capacity, and average efficiency. For this analysis, we modeled ten heating and three cooling technologies. The heating technologies are: natural gas fumaces, oil furmaces, LPG furnaces, electric furnaces, oil boilers, natural gas boilers, electric heat pumps, gas room, electric room and other. The "Other" category for equipment corresponds to the "Other" category for fuels, which include miscellaneous fuels such as wood, cod and kerosene. The cooling technologies are: heat pamps, unitary central air, and room air conditioners. We further differentiate the cooling equipment into primary -- nnitary central air and heat pomps - and secondary $\cdots$ room air conditioners. This distinction is important because it simplifies the cooling equipment choice model (homeowners choose only among primary equipment options), and room air conditioners are often present in homes with central cooling and thus properly should be considered a "secondary" cooling system. Distribution systems include hydronic, forced-air and "none" in our model. The combination of a heating technology, cooling technology and distribution system define a discrete HVAC system in REEPS, so that these systents are tracked independently throughout the course of the model. Instead of treating the three space conditioning end-uses 
separately (heating, ventilation, and air conditioning), this characterization captures some of the physical and economic relationships among them.

\begin{tabular}{|c|c|c|c|c|c|}
\hline \multicolumn{6}{|c|}{ 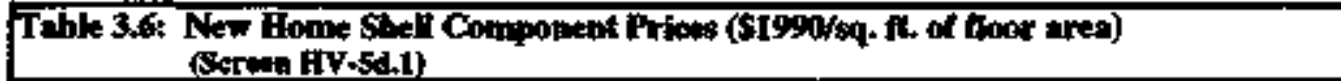 } \\
\hline \multirow{2}{*}{$\begin{array}{l}\text { Component } \\
\text { Descriptions }\end{array}$} & \multirow{2}{*}{$\begin{array}{l}\text { Component } \\
\text { Level }\end{array}$} & \multicolumn{2}{|c|}{ Noth (Clicaro) } & \multicolumn{2}{|c|}{ Sorth (Charlest:mn) } \\
\hline & & 1-stogry & $2 \sin y$ & 1-tory & $2 \operatorname{sectar}$ \\
\hline $\begin{array}{l}\text { Criling } \\
\text { ceiling instutotion } \\
R \text {-value }\end{array}$ & $\begin{array}{l}R-0 \\
R-7 \\
R-11 \\
R-19 \\
R-22 \\
R-30 \\
R-38 \\
R-49 \\
R-60\end{array}$ & $\begin{array}{l}0.00 \\
0.22 \\
0.35 \\
0.49 \\
0.54 \\
0.67 \\
0.83 \\
1.04 \\
1.22 \\
\end{array}$ & $\begin{array}{l}0.00 \\
0.11 \\
0.17 \\
0.24 \\
0.27 \\
0.33 \\
0.41 \\
0.52 \\
0.61 \\
\end{array}$ & $\begin{array}{l}0.00 \\
0.20 \\
0.31 \\
0.46 \\
0.51 \\
0.64 \\
0.84 \\
1.02 \\
1.21 \\
\end{array}$ & $\begin{array}{l}0.00 \\
0.10 \\
0.15 \\
0.23 \\
0.25 \\
0.32 \\
0.42 \\
0.51 \\
0.61\end{array}$ \\
\hline $\begin{array}{l}\text { Woll } \\
\text { wall inswation } \\
\text { R-vatue }\end{array}$ & $\begin{array}{l}R-0 \\
R-7 \\
R-11 \\
R-13 \\
R-19 \\
R-27 \\
R-34 \\
\end{array}$ & $\begin{array}{l}0.00 \\
0.18 \\
0.29 \\
0.33 \\
0.48 \\
1.03 \\
1.22 \\
\end{array}$ & $\begin{array}{l}0.00 \\
0.21 \\
0.33 \\
0.38 \\
0.55 \\
1.18 \\
1.40 \\
\end{array}$ & $\begin{array}{l}0.00 \\
0.17 \\
0.27 \\
0.32 \\
0.46 \\
1.03 \\
1.22 \\
\end{array}$ & $\begin{array}{l}0.00 \\
0.20 \\
0.31 \\
0.37 \\
0.53 \\
1.18 \\
1.40 \\
\end{array}$ \\
\hline $\begin{array}{l}\text { Stab Edge Inssi. } \\
\text { perimeter R-value } \\
\text { and depth }\end{array}$ & $\begin{array}{l}\text { R-0 } \\
\text { R-5 2ft } \\
\text { R-5 4ft } \\
\text { R-10 2ft } \\
\text { R-10 4ft }\end{array}$ & $\begin{array}{l}n / a \\
n / a \\
n / a \\
n / a \\
n / a\end{array}$ & $\begin{array}{l}n / a \\
n / a \\
n / a \\
n / a \\
n / a\end{array}$ & $\begin{array}{l}0.00 \\
0.29 \\
0.37 \\
0.57 \\
0.74 \\
\end{array}$ & $\begin{array}{l}0.00 \\
0.15 \\
0.19 \\
0.30 \\
0.38\end{array}$ \\
\hline $\begin{array}{l}\text { Floom Insalmation } \\
\text { underfloor } R \text { +walue }\end{array}$ & $\begin{array}{l}\mathrm{R}-0 \\
\mathrm{R}-11 \text { frr } \\
\mathrm{R}-19 \text { fir } \\
\mathrm{R}-30 \mathrm{fir} \\
\mathrm{R}-38 \text { fir } \\
\end{array}$ & $\begin{array}{l}0.00 \\
0.42 \\
0.65 \\
0.80 \\
0.90 \\
\end{array}$ & $\begin{array}{l}0.00 \\
0.21 \\
0.32 \\
0.40 \\
0.45 \\
\end{array}$ & $\begin{array}{l}0.00 \\
0.39 \\
0.60 \\
0.73 \\
0.82 \\
\end{array}$ & $\begin{array}{l}0.00 \\
0.19 \\
0.30 \\
0.36 \\
0.41 \\
\end{array}$ \\
\hline $\begin{array}{l}\text { In flitration } \\
\text { ACH }\end{array}$ & $\begin{array}{l}0.8 \\
0.7 \\
0.55 \\
0.4 \\
\end{array}$ & $\begin{array}{l}0.00 \\
0.00 \\
0.19 \\
0.38 \\
\end{array}$ & $\begin{array}{l}0.00 \\
0.00 \\
0.13 \\
0.26 \\
\end{array}$ & $\begin{array}{l}0.00 \\
0.00 \\
0.18 \\
0.36 \\
\end{array}$ & $\begin{array}{l}0.00 \\
0.00 \\
0.13 \\
0.25 \\
\end{array}$ \\
\hline $\begin{array}{l}\text { Woilows } \\
\text { no. of puresidestign }\end{array}$ & $\begin{array}{l}\text { 1,0-gla } \\
2,0 \text {-gla } \\
2-g \text { b loE } \\
\text { 2-gla loEAr } \\
\text { Spectrally Sel. } \\
\text { Superwindow } \\
\text { Heat Minur } \\
\end{array}$ & & & & \\
\hline 2-6tory. & $\begin{array}{l}\text { 199lb), Koom: } \\
\text { verage floor a }\end{array}$ & & 946 & In & \\
\hline
\end{tabular}

For each technology the REEPS model requires five types of data, discussed in Sections 4.1-4.4. The data include: vintage blocks for the existing equipment stock, equipment lifetimes, average capacity or size for each housing type, average efficiency of new equipment, and the unit energy consumption (UEC) by housing type. The lifetimes and vintage blocks are used to track purchases and retirements of equipment throughout the course of the forecast period. The capacity of equipment is used to determine its purchase price in future years and to calculate average usage or utilization over the course of a heating or cooling season. The UEC provides a calibration value for the energy consumed by each technology in a given housing type. The 
average efficiency of new eqtipment provides a cakibration value for the efficiency choice of new and replacement equipment. The user also defines HVAC systems and inputs market shares for these systems in pew and existing homes, which we discuss in Section 4.5. Although room air conditioners are not a primary equipment type in our model formulation and thus do not require the same extensive input data as the other primary options, we report the above data for room air conditioners as well, for the sake of completeness.

\section{Vintage Blocks}

The vintage of equipment refers simply to the year or group of years in which it was purchased. REEPS allows the user to configore vintage blocks for each type of heating and cooling equipment. The vintage block data developed for this study are shown in Tables 4,1-N\&S.

\begin{tabular}{|c|c|c|c|c|c|c|c|}
\hline \multicolumn{8}{|c|}{ 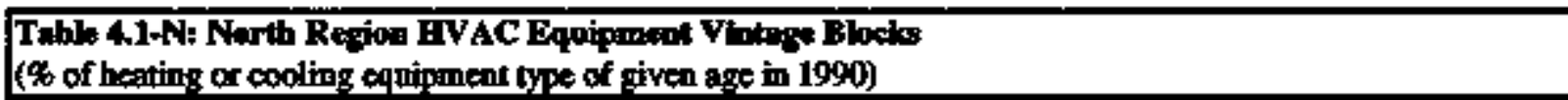 } \\
\hline End-Use & Technolos & LIR & 2-4YR & 5-9YR & \$0-19YR & $>20 \mathrm{YR}$ & Tot: \\
\hline \multicolumn{8}{|c|}{ Heatlin: (Screen HV-3b,3) } \\
\hline & $\begin{array}{l}\text { Electric Fumace } \\
\text { Gas Furtace } \\
\text { OAl Furnace } \\
\text { LPG Furnace } \\
\text { Electric Heat Pump } \\
\text { Gas Hydronics } \\
\text { Oll Hydronics } \\
\text { Electric Room } \\
\text { Gas Room } \\
\text { Oher Equipment }\end{array}$ & $\begin{array}{l}1 \% \\
9 \% \\
10 \% \\
21 \% \\
9 \% \\
11 \% \\
9 \% \\
7 \% \\
9 \% \\
7 \%\end{array}$ & $\begin{array}{l}10 \% \\
17 \% \\
18 \% \\
22 \% \\
31 \% \\
9 \% \\
13 \% \\
5 \% \\
7 \% \\
22 \%\end{array}$ & $\begin{array}{l}18 \% \\
18 \% \\
16 \% \\
18 \% \\
26 \% \\
13 \% \\
15 \% \\
18 \% \\
12 \% \\
32 \%\end{array}$ & $\begin{array}{l}65 \% \\
29 \% \\
23 \% \\
24 \% \\
32 \% \\
27 \% \\
21 \% \\
39 \% \\
36 \% \\
23 \%\end{array}$ & $\begin{array}{l}6 \% \\
27 \% \\
34 \% \\
16 \% \\
3 \% \\
41 \% \\
42 \% \\
30 \% \\
36 \% \\
11 \%\end{array}$ & $\begin{array}{l}100 \% \\
100 \% \\
100 \% \\
100 \% \\
100 \% \\
100 \% \\
100 \% \\
100 \% \\
100 \% \\
100 \%\end{array}$ \\
\hline \multicolumn{8}{|c|}{ Cooling: (Screen HV-3e.3) } \\
\hline & $\begin{array}{l}\text { Central Air } \\
\text { Eatric Heat Pump } \\
\text { Roow Air }\end{array}$ & $\begin{array}{l}13 \% \\
9 \% \\
13 \%\end{array}$ & $\begin{array}{l}23 \% \\
21 \% \\
25 \%\end{array}$ & $\begin{array}{l}19 \% \\
37 \% \\
28 \%\end{array}$ & $\begin{array}{l}35 \% \\
33 \% \\
27 \%\end{array}$ & $\begin{array}{l}10 \% \\
0 \% \\
7 \%\end{array}$ & $\begin{array}{l}100 \% \\
100 \% \\
100 \%\end{array}$ \\
\hline
\end{tabular}

Table 4.1-S: South Region EVAC Equipanent Vintage Blocks

(\% of treating or cooling exuignent type of given age in 1990)

\begin{tabular}{|c|c|c|c|c|c|c|c|}
\hline Endolse & Tocknolory & $\langle 2 \mathrm{YA}$ & $24 \mathrm{KR}$ & S.9YR & 16-[9YR & $>25 \mathrm{rR}$ & Tota \\
\hline \multicolumn{8}{|c|}{ Fingting (Scred HV+3b.3) } \\
\hline & $\begin{array}{l}\text { Flectric Furnace } \\
\text { Gas Fumace } \\
\text { Oil Furnace } \\
\text { LFG Furnace } \\
\text { Flectric Heal Pump } \\
\text { Gas Hydronics } \\
\text { Oil Hydronics } \\
\text { Flectric Room } \\
\text { Gas Room } \\
\text { Other Egutoment }\end{array}$ & $\begin{array}{l}5 \% \\
7 \% \\
5 \% \\
18 \% \\
13 \% \\
10 \% \\
0 \% \\
10 \% \\
5 \% \\
10 \%\end{array}$ & $\begin{array}{l}10 \% \\
11 \% \\
15 \% \\
16 \% \\
21 \% \\
17 \% \\
0 \% \\
21 \% \\
8 \% \\
30 \%\end{array}$ & $\begin{array}{l}26 \% \\
23 \% \\
19 \% \\
28 \% \\
42 \% \\
9 \% \\
0 \% \\
20 \% \\
16 \% \\
27 \%\end{array}$ & $\begin{array}{l}48 \% \\
35 \% \\
24 \% \\
30 \% \\
20 \% \\
23 \% \\
31 \% \\
24 \% \\
23 \% \\
26 \%\end{array}$ & $\begin{array}{l}10 \% \\
24 \% \\
38 \% \\
9 \% \\
4 \% \\
42 \% \\
69 \% \\
26 \% \\
48 \% \\
8 \%\end{array}$ & $\begin{array}{l}100 \% \\
100 \% \\
100 \% \\
100 \% \\
100 \% \\
100 \% \\
100 \% \\
100 \% \\
100 \% \\
100 \%\end{array}$ \\
\hline \multicolumn{8}{|c|}{ Cooling (Screen HV-3e.3) } \\
\hline & \begin{tabular}{|l} 
Central Air \\
Flectric Heat Pump \\
Room Air
\end{tabular} & $\begin{array}{l}12 \% \\
10 \% \\
11 \%\end{array}$ & $\begin{array}{l}16 \% \\
27 \% \\
21 \%\end{array}$ & $\begin{array}{l}29 \% \\
40 \% \\
34 \%\end{array}$ & $\begin{array}{l}33 \% \\
20 \% \\
27 \%\end{array}$ & $\begin{array}{l}10 \% \\
3 \% \\
7 \%\end{array}$ & $\begin{array}{l}100 \% \\
100 \% \\
100 \%\end{array}$ \\
\hline
\end{tabular}


For each vintage block, the user must estimate the average efficiency of currently installed equipment and the share of the total stock it represents. The vintage blocks are used to account for changes in the stock efficiency due to retirements and replacements of equipment. Vintage blocks can also be used as a means of comelating equipment vintages with the vintages of the buildings themselves, which are also retired, although at a much slower rate. We used data from the 1990 RECS to develop five vintage blocks for each equipment type in each region. We estimated the efficiency for a given equipment type and vintage block by using the ShipmentWeighted Energy Factors (SWEFs) for the years $1970-1990$, as provided by several trade groups which track this data for their members (AHAM 1991, ARI 1991, GAMA 1992). For early years such as 1970-72 in which the datg were sometimes not available, we substituted the SWEF from the nearest available year.

The regional specification of vintage blocks (as opposed to using the same vintage blocks for both regions) can have an important effect on the model results in cases where existing cquipment is substantially different than new equipunent. There are several reasons for these differences. First, new construction has historically been concentrated in one region or another during a particular period. In our regional breakdown, housing construction has been concentrated in the south in the past decade, so that a greater percentage of equipment in the south is newer and hence more efficient. Second, some types of equipment are much more popular in one region than another, such as oil fumaces in the north, and the vintage blocks reflect this equipment's particular regional vintages rather than the national average vintages. Finally, some types of equipment have had slower rates of adoption in one region than another so that the vintage profiles are quite different. This is the case with heat pumps, which have been adopted much more slowly in the north compared to the south and thus on average are newer in the north. Appendix B contains the full specification of vintage blocks for each equipment type.

\subsection{HVAC Equipment Ufetimes}

The lifetime of equipment determines both when replacement equiproent will be needed in the course of the forecast and also the life-cycle cost of equipment given a finite equipment lifetime. We used field extimates of equipment lifetime parameters (Lewis and Clarke 1990), as shown in Table 4.2 .

\begin{tabular}{|c|c|c|c|c|}
\hline \multirow[b]{2}{*}{ Endadse } & \multirow[b]{2}{*}{ Tecinoto:g } & \multicolumn{3}{|c|}{ Equipanent Lifotimes (Years) } \\
\hline & & Minimam & Avetibe & Mrximm \\
\hline Beating (Screen HV-2b-2) & $\begin{array}{l}\text { Electric Funace } \\
\text { Gas Funace } \\
\text { Oil Furnace } \\
\text { Electric Heat Ponp } \\
\text { Gas Hydronics (boiler) } \\
\text { Oil Hydronics (bolles) } \\
\text { Electric Room } \\
\text { Gas Room } \\
\text { Other Equiponent }\end{array}$ & $\begin{array}{l}20 \\
15 \\
15 \\
10 \\
20 \\
20 \\
15 \\
15 \\
10\end{array}$ & $\begin{array}{l}2.5 \\
17.5 \\
17.5 \\
12.5 \\
25 \\
25 \\
17.5 \\
17.5 \\
12.5\end{array}$ & $\begin{array}{l}25 \\
20 \\
20 \\
15 \\
30 \\
30 \\
20 \\
20 \\
15\end{array}$ \\
\hline Cooling (Screen HV-2ch) & $\begin{array}{l}\text { Central Air } \\
\text { Electric Heat Pomp } \\
\text { Room Air }\end{array}$ & $\begin{array}{l}11 \\
10 \\
10\end{array}$ & $\begin{array}{l}13.5 \\
12.5 \\
12.5\end{array}$ & $\begin{array}{l}16 \\
15 \\
15\end{array}$ \\
\hline
\end{tabular}

Decay of exuipment occurs when it reaches the end of its useful lifetime. It is modeled by a decay function that removes some portion of the stock of equipment each year and replaces it with new equipment. In the REEPS HVAC module, the user specifies maximmm and minimum 
equipment lifetimes, and the equipment stock decays linearly between those two points. For example, consider a certain technology having a minimum lifetime of 5 years and a maximum lifetime of 15 years. For a stock of equipment purchased in a given year, say $1986,100 \%$ will survive until the minimum lifetime is reached in 1991. Each year between 1991 and the maximum lifetime in $2001,10 \%$ of the stock will decay and need to be replaced. After 2001, none of the stock purchased in 1986 will remain.

\subsection{HVAC Equipment Capacity and Eficiency Data}

The output capacity of space conditioning equipment refers to its capability to deliver heating or cooling energy under nomal operating conditions. Energy input $\left(Q_{\text {in }}\right)$ and energy output ( $\left.Q_{\text {out }}\right)$ for heating and cooling equipment are often measnred in thousand Btu per hour (kBtuh). The rated efficiency of space conditioning equipment incorporates its tested performance over an average heating or cooling season under specified conditions, thereby accounting for cycling and other performance features of the equipment not caphred by the steady-state efficiency. Efficiency is generally measured with Annual Fuel Utilization Efficiency (AFUE) for fuels and Seasonal Energy Efficiency Ratios (SEER) for heat puraps and central air conditioning. The one exception to this convention is room air conditioners, whose efficiency is measured by the steady-state Energy Efficiency Ratio (EER), because these equipment tend to operate at full load nearly the whole time they are operated. We obtained data on the capacity and efficiency of manufacturers' shipments of heating and cooling equipment from reports and equipment catalogs produced by the relevant trade organizations (AHAM 1991, ARI 1991, GAMA 1992, Hydronics Institute 1992). The efficiency definitions and units ane shown in Table 4.3 along with the average capacity and efficiency. Efficiency of electric heating equipment is assumed to be $100 \%$. The efficiency levels cited do not include duct losses. The data are for the most recent year available.

\begin{tabular}{|c|c|c|c|c|c|}
\hline End-Uee & Teclunology & $\begin{array}{l}\text { Driciency } \\
\text { Untits }\end{array}$ & $\begin{array}{c}1992 \\
\text { Federal } \\
\text { studind }\end{array}$ & $\begin{array}{l}1990 \\
\text { SWEF }\end{array}$ & $\begin{array}{l}1990 \\
\text { Avs. Stase } \\
\text { (abtub) }\end{array}$ \\
\hline \multirow[t]{2}{*}{ Heating } & & & (Sctitens) & (HV-4c) & (HV+3b.1) \\
\hline & 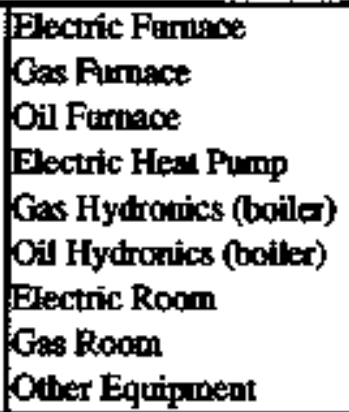 & $\begin{array}{l}\text { None } \\
\text { AFUE } \\
\text { AFUE } \\
\text { HSPF } \\
\text { AFUE } \\
\text { AFUE } \\
\text { None } \\
\text { AFUE } \\
\text { AFUE }\end{array}$ & $\begin{array}{l}78.0 \\
78.0 \\
6.8 \\
80.0 \\
80.0 \\
65.0 \\
78.0\end{array}$ & $\begin{array}{l}75.8 \\
80.3 \\
7.03 \\
79.6 \\
84.0 \\
67.0 \\
70.0\end{array}$ & $\begin{array}{c}\text { not applicable } \\
90.1 \\
101.3 \\
34.2 \\
104.2 \\
107.2 \\
\text { not applicable } \\
38.5 \\
80.0 \\
\end{array}$ \\
\hline \multirow[t]{2}{*}{ Cooting } & & & (Scres): & $(H V-4 d)$ & (HV-3e.1) \\
\hline & $\begin{array}{l}\text { Central Air } \\
\text { Electric Hest Pump } \\
\text { Rocm Air }\end{array}$ & $\begin{array}{l}\text { SEER } \\
\text { SEER } \\
\text { EER }\end{array}$ & $\begin{array}{l}10.0 \\
10.0 \\
9.0\end{array}$ & $\begin{array}{l}9.24 \\
9.41 \\
8.73\end{array}$ & $\begin{array}{l}34.6 \\
34.2 \\
10.8\end{array}$ \\
\hline \multicolumn{6}{|c|}{ 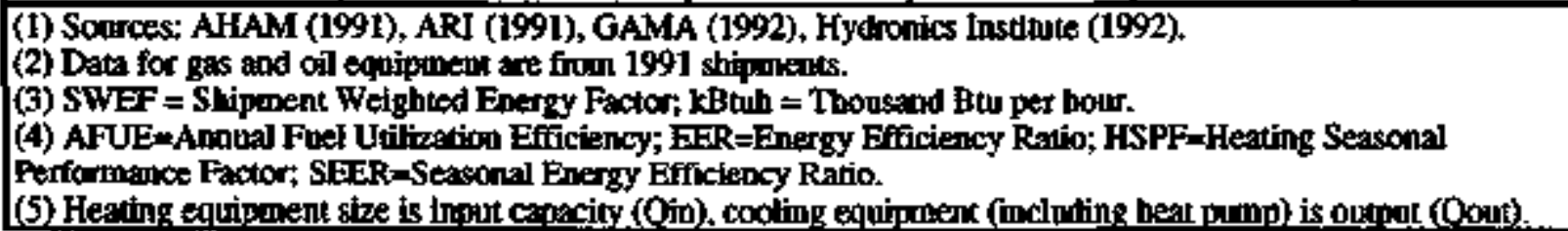 } \\
\hline
\end{tabular}


REEPS also requires data on the average capacity of HVAC equipment in the base year, disaggregated by house type. We developed these data using the same manufacturer shipment data described above, and then allocated the shipments to particular house types using the thermal loads from Section 3 and the equipment sizing factors that are shown in Section 5.1. The average capacities are shown in Tables 4.4N and 4.4-S.

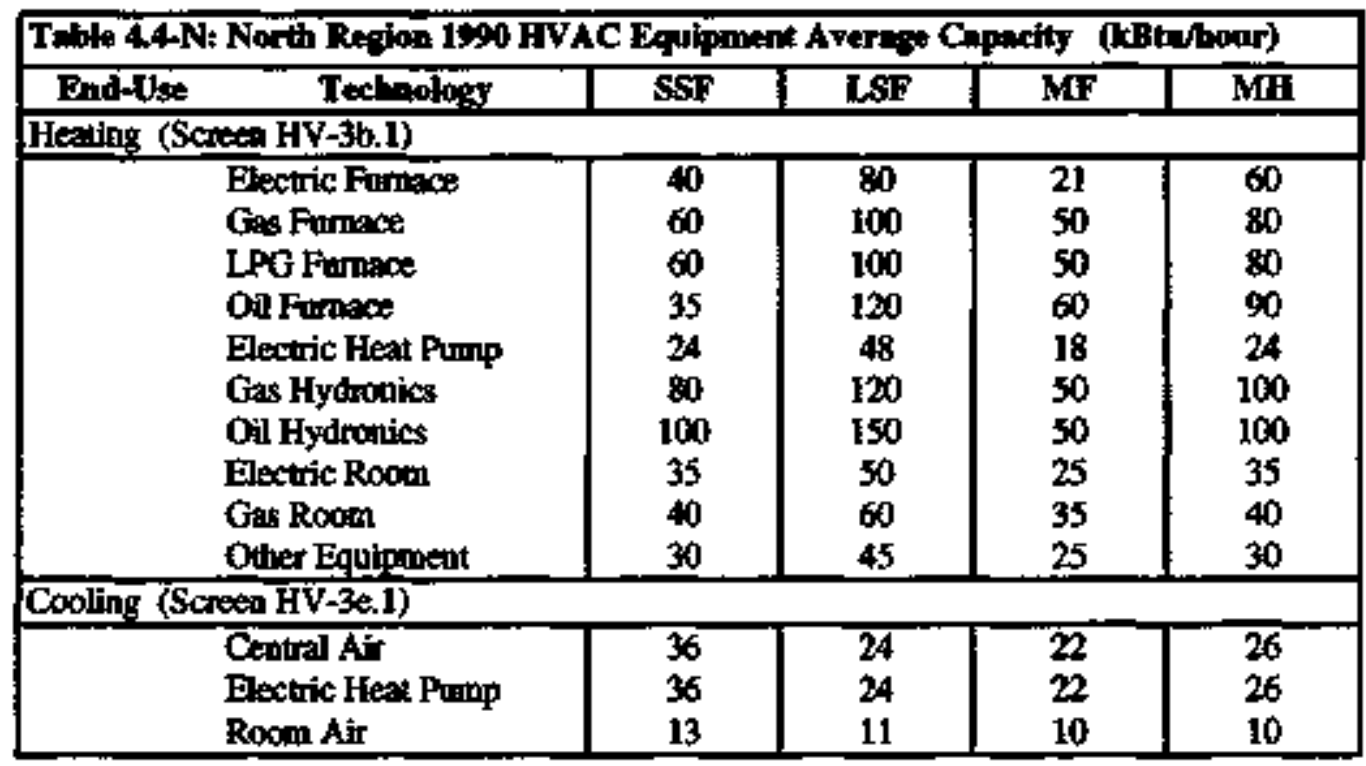

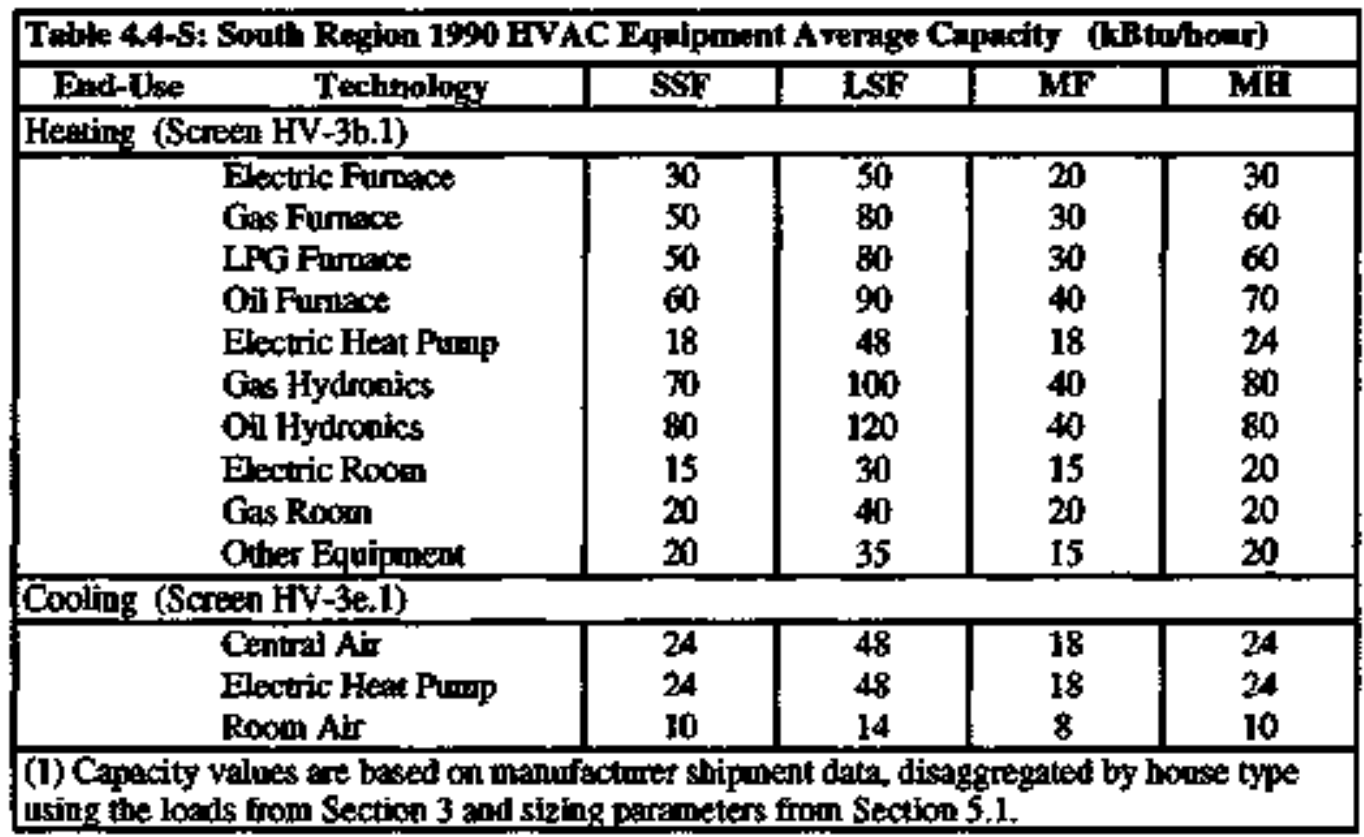

We also obtained data on the distribution of size and efficiency within manufacturers' annual shipment totals, for either 1990 or 1991, which are documented in Appendix C. We had no data for either central electric furnaces or electric room heaters. As the three-dimensional graphs in Appendix C illustrate, the efficiency distribution of shipments is generally not uniform for all equipment sizes (i.e., some sizes of equipment have efficiency distributions that are skewed toward high or low efficiency models). There are many reasons for these differences, sach as physical design constraints, differences in the cost-effectiveness of marginal improvements in efficiency, market niches occupied by different sizes of equipment, and the types of buildings in 
which particular equipment sizes are generally installed. Although we empirically observe that equipment efficiency varies with capacity, the REEPS model assumes for the sake of simplicity that efficiency is independent of capacity. Nevertheless, the simplified efficiency distributions are important for sizing equipment and modeling efficiency choice.

\subsection{Unit Energy Consumption Estimates}

Estimates of tmit energy consumption (UEC) are important drivers in the HVAC model because they determine the basic trend of energy consumption and are used to calibrate usage equations for each type of equipment. LECs are specified for each region, housing type and each type of heating and cooling equipment, as shown in Tables 4.5-N and 4.5-S.

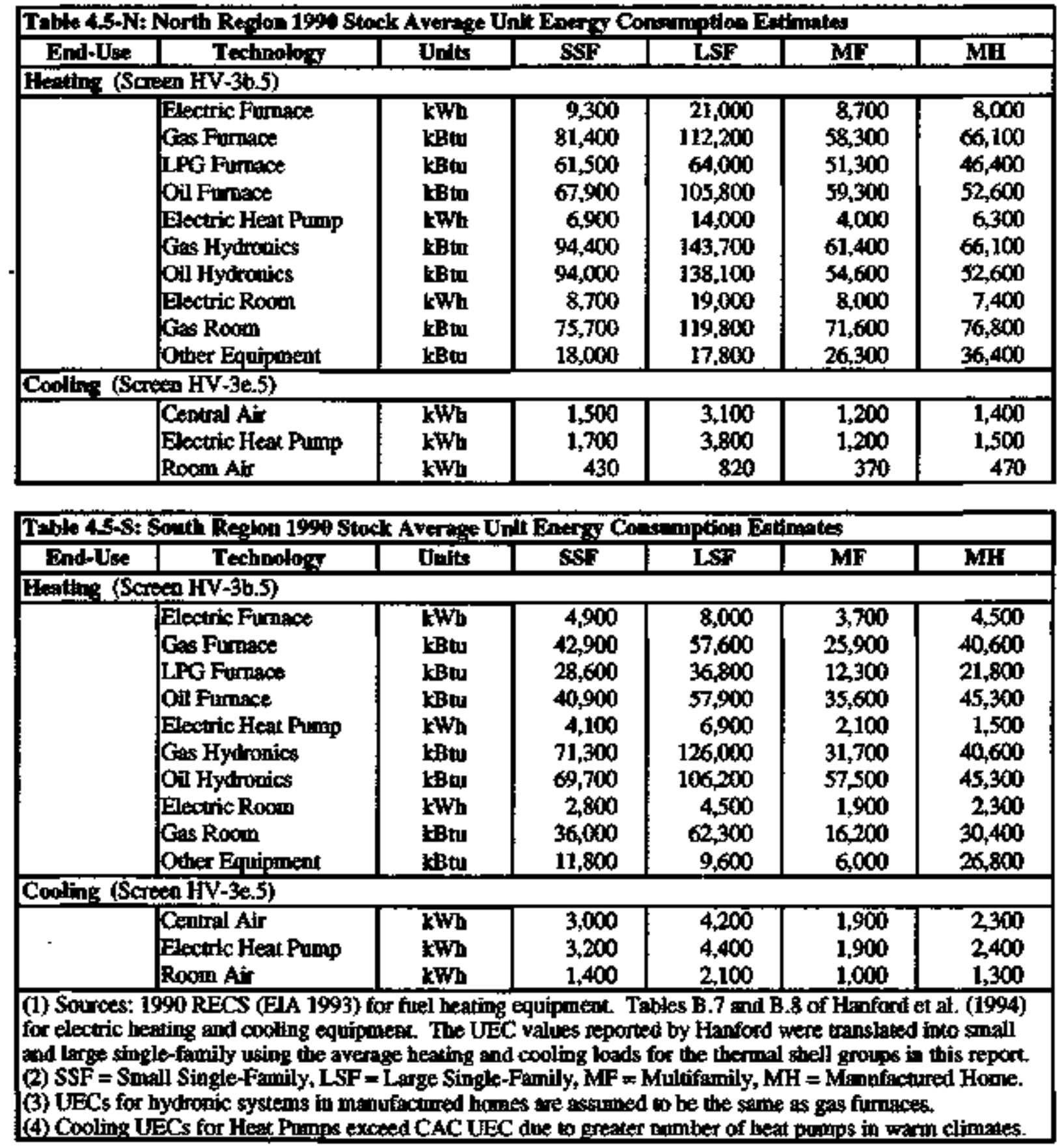


The UECs for this analysis are drawn from the 1990 RECS consumption estimates ${ }^{4}$ for fuel-fired heating equipment (EIA 1993), and a compilation of utility survey data (Hanford et al. 1994) for electric heating and cooling equipment. The measurement mits for UECs are kilowatt-howrs (kWh) for electric and thousands of BTUs (kBTUs) for fuels. REEPS also permits the user to separately consider the energy consumption resulting from secondary heating and cooling and electricity used by ventilation fans. As mentioned earlier, we treat room air conditioners as secondary equipment, because the REEPS model allows simpler accounting of their energy use in this way. We do not make use of the secondary beating option because it is too difficult to correlate secondary consumption with the main heating equipment.

\subsection{HVAC Equipment Market Shores}

We now define feasible HVAC systems based on combinations of the heating and cooling equipment and the distribution systems defined in the preceding sections. These crosstabulations between heating and cooling systems account for physical and economic dependencies among the heating and cooling equipment types. The REEPS HVAC modale allows the user to group the systems using any criteria such as cooling type or distribution system. We adopt a simple framework in which systems with and without central air conditioning form the basis of the system types. We considered all possible combinations of heating and cooling equipment but chose only those with $1 \%$ or more market share in either region, resulting in sixteen discrete HVAC systems. This specification of system type also allows the decision models to be estimated using a nested logit approach, in which the decision is modeled as two levels: the upper level is a choice of central cooling and the lower level is a choice of heating equipment. We will discuss the nested logit decision model in Section 6.3.

We developed market share data for the sixteen HVAC systems, differentiated by existing and new homes and by each of the four housing types, as shown in Tables 4.6-N\&S and 4.7-N\&S. These market share data are used in REEPS both to allocate households to the fifferent HVAC systems and to calibrate the decision model for new homes. The market share data for existing buildings are from the 1990 RECS (EIA 1993) while market share data for new buildings were developed by cross-tabulating the RECS data for 1980 s vintage homes with the census data for 1990 construction (US Bureat of the Census 1991).

In addition, REEPS requires data on the market share of secondary cooling equipment - room air conditioners - in the housing stock in order to forecast the saturation of these units. For use in REEPS, these data are disageregated according to the presence and type of central cooling equipment. Table 4.8 shows the market share of room air conditioners for both the north and south regions.

Each combined beating and cooling HVAC system is associated with one of the five shell groups (HP, Elec, NG/CA, Fuels, Other) defined in Section 3.3. The association of HVAC equipment and shell groups allows for more accurate modeling of important interactions between the equipment characteristics and the building heating and cooling loads. The shell groups, in tum, include a distribution of thernal integrity levels by assigning market shares to the themal shell packages, as described in Section 3.3.

\footnotetext{
${ }^{4}$ The 1990 RECS consumption valnes are based on billing data at the bousebold level, which are then disaggregated into component end-uses by means of a conditional demand amalysis model. Thus, al though based on measured dath, the RECS UEC values should propeffy be considened estimates rather than "pure" measured (sub-metered) data.
} 


\begin{tabular}{|c|c|c|c|c|c|}
\hline \multicolumn{6}{|c|}{ 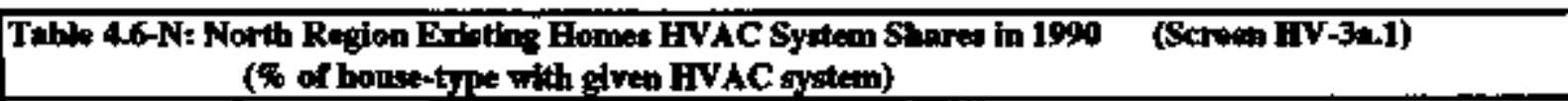 } \\
\hline \multirow[t]{2}{*}{ System Na } & \multirow[t]{2}{*}{ Cootind filenting Combination } & \multicolumn{4}{|c|}{ Blowing type } \\
\hline & & SSP & LSF & $\mathbf{M F}$ & MH \\
\hline $\begin{array}{l}1 \\
2 \\
3 \\
4 \\
5 \\
6 \\
7 \\
8 \\
9 \\
10 \\
11 \\
12 \\
13 \\
14 \\
15 \\
16 \\
\end{array}$ & 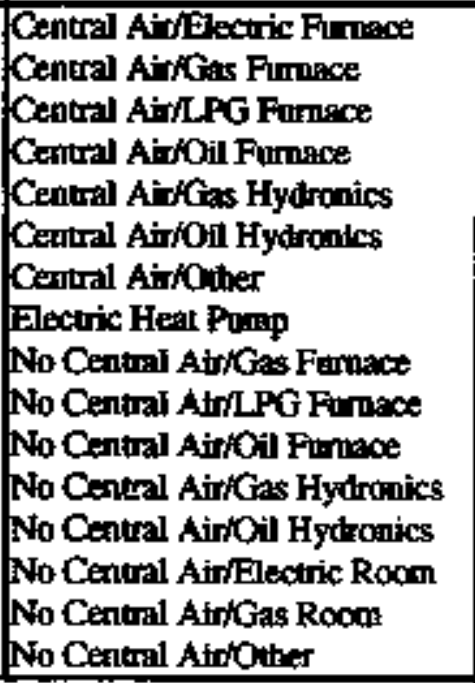 & $\begin{array}{r}1.2 \% \\
19.2 \% \\
1.2 \% \\
1.2 \% \\
0.6 \% \\
0.9 \% \\
0.6 \% \\
2.3 \% \\
27.2 \% \\
3.4 \% \\
8.5 \% \\
7.0 \% \\
5.9 \% \\
9.2 \% \\
3.0 \% \\
8.6 \% \\
\end{array}$ & $\begin{array}{r}1.8 \% \\
27.0 \% \\
1.5 \% \\
2.2 \% \\
1.4 \% \\
4.3 \% \\
0.7 \% \\
2.2 \% \\
20.3 \% \\
1.9 \% \\
5.2 \% \\
11.0 \% \\
11.1 \% \\
4.9 \% \\
0.4 \% \\
4.1 \% \\
\end{array}$ & $\begin{array}{r}7.0 \% \\
8.6 \% \\
0.0 \% \\
0.2 \% \\
0.7 \% \\
0.3 \% \\
0.0 \% \\
1.7 \% \\
14.1 \% \\
0.3 \% \\
2.1 \% \\
31.4 \% \\
16.1 \% \\
13.0 \% \\
3.4 \% \\
1.1 \% \\
\end{array}$ & $\begin{array}{r}6.3 \% \\
18,3 \% \\
2.6 \% \\
12 \% \\
0.0 \% \\
0.0 \% \\
0.0 \% \\
0.8 \% \\
22.5 \% \\
12.8 \% \\
6.1 \% \\
0.0 \% \\
0.0 \% \\
12.9 \% \\
0.4 \% \\
16.1 \% \\
\end{array}$ \\
\hline & Totals & $100.0 \%$ & 1000 & $100.0 \%$ & $100.0 \%$ \\
\hline
\end{tabular}

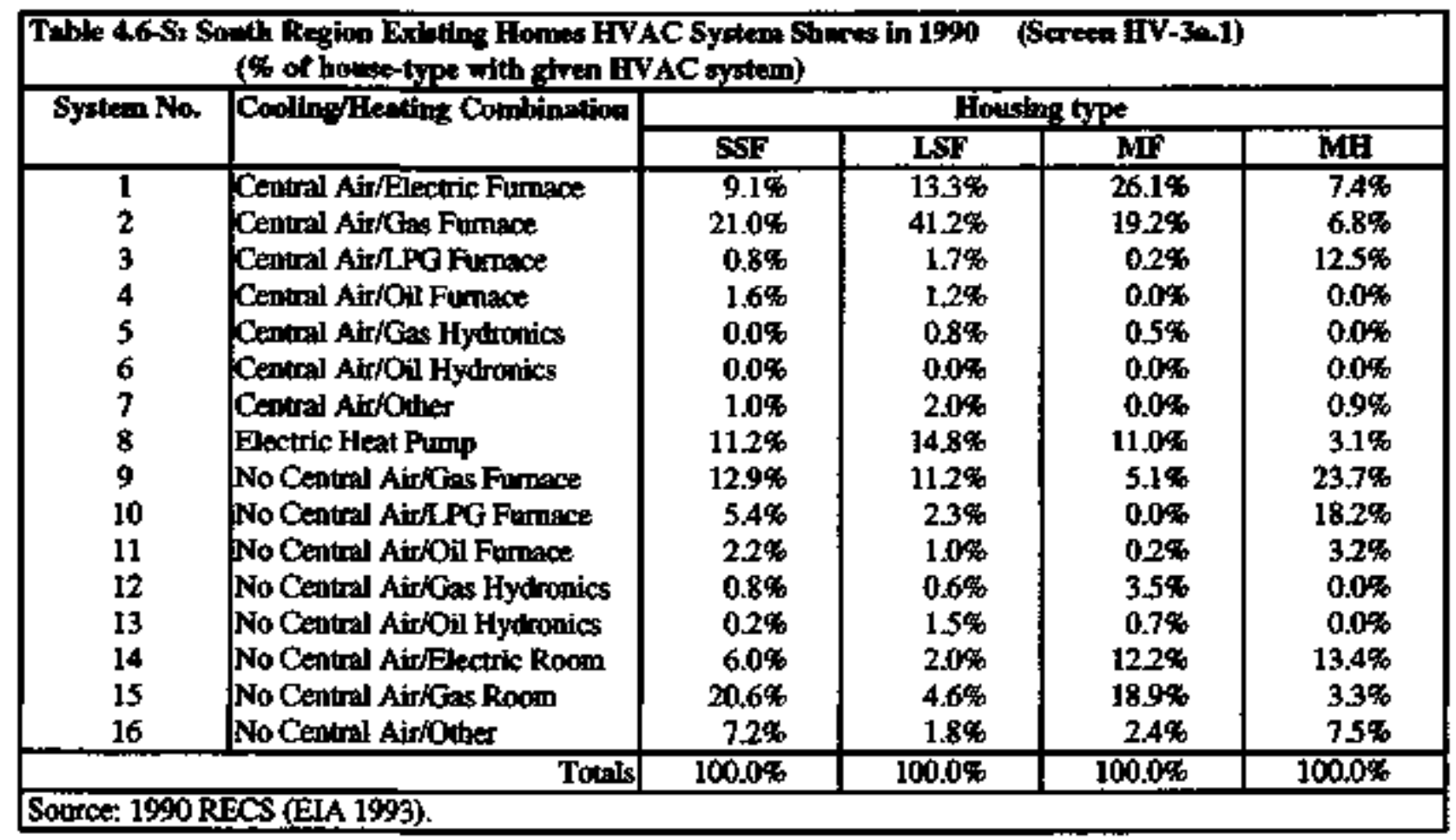




\begin{tabular}{|c|c|c|c|c|c|}
\hline Table 4.7-Nz & $\begin{array}{l}\text { North Rejion New Homes HVAC } \\
\text { (\% of bouse-type with tiven BV }\end{array}$ & systam & Sereen & & \\
\hline Sjaten Na. & Cooling/feesting Combimating & & & spe & \\
\hline & & SSF & LSF & $\mathbf{M I F}$ & MA \\
\hline$\overline{1}$ & Central A frf Electric Funace & $10.0 \%$ & 0,00 & $16.5 \%$ & $8.2 \%$ \\
\hline 2 & Ceutral Air/Gas Furnace & $26.6 \%$ & $68.9 \%$ & $413 \%$ & 28.746 \\
\hline 3 & Central AiriLPG Funace & $0.6 \%$ & $0.6 \%$ & $0.0 \%$ & $4.9 \%$ \\
\hline 4 & Central Air/Oil Furnowe & $0.0 \%$ & $0,0 \%$ & $0.0 \%$ & $0.0 \%$ \\
\hline 5 & Central AirkGes Hydronics & $0.0 \%$ & $1.1 \%$ & 0,0 & $0.0 \%$ \\
\hline 6 & Central AirfOil Hydronics & $0.0 \%$ & $1.2 \%$ & $0.0 \%$ & $0.0 \%$ \\
\hline 7 & Central Airlotier & $03 \%$ & $0.4 \%$ & $0.0 \%$ & $0.0 \%$ \\
\hline 8 & Flectric Heat Pump & $19.0 \%$ & $8.3 \%$ & $13.0 \%$ & $0.0 \%$ \\
\hline 9 & No Central Airflas Fumace & $18.8 \%$ & $3.8 \%$ & $2.6 \%$ & 23.1\% \\
\hline 10 & No Central Ait/LPG Furnace & $0.5 \%$ & $1.0 \%$ & $1.7 \%$ & $14,0 \%$ \\
\hline 11 & No Central Air/Oil Funtsce & $3.2 \%$ & $1.2 \%$ & $0.0 \%$ & $4.0 \%$ \\
\hline 12 & No Central AirkGas Hydronies & $1.1 \%$ & $3.4 \%$ & $16.5 \%$ & $0.0 \%$ \\
\hline 13 & No Central AirfOil Hydrchics. & $84 \%$ & $8.4 \%$ & $2.4 \%$ & $0.0 \%$ \\
\hline 14 & No Central AtriElectric Room & $6.1 \%$ & $1.1 \%$ & $6.1 \%$ & $1,0 \%$ \\
\hline 15 & No Central Ai AGas Rocm & $0.0 \%$ & $0.0 \%$ & $0.0 \%$ & $0.0 \%$ \\
\hline 16 & No Central AirkOther & $55 \%$ & $0.5 \%$ & $0.0 \%$ & $16.1 \%$ \\
\hline & Totals: & $100 \%$ & $100 \%$ & $100 \%$ & $100 \%$ \\
\hline
\end{tabular}

\begin{tabular}{|c|c|c|c|c|c|}
\hline Table 4.7-S: & $\begin{array}{l}\text { iogth Regiog New Homes HVAC } \\
\text { (\% of hoose-type whith gtven BV }\end{array}$ & tem Sh & $\overline{\text { creen } \mathbf{B}}$ & & \\
\hline System Na. & Coollng/feating Comblration & & & & \\
\hline & & SSF & LSF & MF & MH \\
\hline $\mathbf{5}$ & Central Air/Electric Fumace & $11.8 \%$ & $5.8 \%$ & $21.6 \%$ & $15,0 \%$ \\
\hline 2 & Central Air/Gas Furace & $30.8 \%$ & $59.4 \%$ & $18.5 \%$ & 5.48 \\
\hline 3 & Central Air/LPG Fumace & $04 \%$ & $1.1 \%$ & $1.0 \%$ & $24.5 \%$ \\
\hline 4 & Central AirlOi Furuace & $0.0 \%$ & $0.0 \%$ & $0.0 \%$ & $0.0 \%$ \\
\hline 5 & Central Air/Otas Hydronics & $0.0 \%$ & $0.0 \%$ & $0.0 \%$ & $0.0 \%$ \\
\hline 6 & Central Air/Oi Hydronics & $0.0 \%$ & $0.0 \%$ & $0.0 \%$ & $0.0 \%$ \\
\hline 7 & Centrol Airkother & $1.4 \%$ & $1.1 \%$ & $0.0 \%$ & $2.3 \%$ \\
\hline 8 & Electric Heat Pump & $38.5 \%$ & $25.5 \%$ & $35.6 \%$ & $6.5 \%$ \\
\hline 9 & No Central Air/Gas Furnace & $7.4 \%$ & $4,2 \%$ & $10.6 \%$ & $23.2 \%$ \\
\hline 10 & No Central Ain/LPG Funace & $13 \%$ & $0.0 \%$ & $0.0 \%$ & $17.0 \%$ \\
\hline 11 & No Central Airfoil Furnace & $0.0 \%$ & $0.0 \%$ & $0.0 \%$ & 3.95 \\
\hline 12 & No Central AirfGas Hydronics & $0.0 \%$ & $0.5 \%$ & $0.0 \%$ & $0.0 \%$ \\
\hline 13 & No Central AirfOil Hydronics & $0.0 \%$ & $0.0 \%$ & $0.0 \%$ & $0,0 \%$ \\
\hline 14 & No Central Air/Electric Room & $4.7 \%$ & $1.5 \%$ & $8.5 \%$ & 1.00 \\
\hline 15 & No Central Air/Gas Room & $09 \%$ & $0.0 \%$ & $3.6 \%$ & $1.0 \%$ \\
\hline 16 & No Central Aintouhex & $3.0 \%$ & $0.8 \%$ & $0.6 \%$ & $0.0 \%$ \\
\hline & Totak: & $100 \%$ & 100\% & $100 \%$ & $100 \%$ \\
\hline (c) & $\begin{array}{l}\text { S built } 1980 \text { to } 1990 \text { (E) } \\
\text { based on C-25 date. RE } \\
\text { com heratitg shores have } \\
1994 \text { ). The RECS hhe } \\
\text { stams. }\end{array}$ & 93): 1 & repot of & & $\begin{array}{l}\text { 1991). } \\
\text { ment ty }\end{array}$ \\
\hline
\end{tabular}




\begin{tabular}{|c|c|c|c|c|c|}
\hline \multicolumn{6}{|c|}{$\begin{array}{c}\text { Toble 4.8: Room Air Cothidioner Market Shares bo } 19 \\
\text { (\% of central cooling-type whl RAC) }\end{array}$} \\
\hline \multirow[t]{2}{*}{ Region } & \multirow[t]{2}{*}{ Cenkral Coo"sig Sjsten } & \multicolumn{4}{|c|}{ Bousing type } \\
\hline & & SSF & ISF & $\overline{\mathbf{M T}}$ & MH \\
\hline North & $\begin{array}{l}\text { Central Air } \\
\text { He* Puinp } \\
\text { No Central Air }\end{array}$ & $\begin{array}{l}4.0 \% \\
0.0 \% \\
42 \%\end{array}$ & $\begin{array}{l}8.4 \% \\
13 \% \\
44 \%\end{array}$ & $\begin{array}{l}4.2 \% \\
0.0 \% \\
52 \%\end{array}$ & $\begin{array}{l}4.1 \% \\
0.0 \% \\
37 \%\end{array}$ \\
\hline Sonth & $\begin{array}{l}\text { Central Air } \\
\text { Heat Pump } \\
\text { No Central Air }\end{array}$ & $\begin{array}{l}8.7 \% \\
3.8 \% \\
54 \%\end{array}$ & $\begin{array}{l}10 \% \\
3.0 \% \\
49 \%\end{array}$ & $\begin{array}{l}0.0 \% \\
0.0 \% \\
41 \%\end{array}$ & $\begin{array}{l}7.4 \% \\
0.0 \% \\
53 \%\end{array}$ \\
\hline
\end{tabular}

\section{EQUIPMENT SIZE, USAGE AND PRICE MODELS}

The usage and size of HVAC equipment are modeled through structural equations in REEPS. Usage for space conditioning equipment is specified in units of $\mathrm{kWh}$ per year for electric equipment and kBtu per year for fuels. The first section describes the development of the model to estimate equipment sizing. The second section presents the Unit Energy Consumption data for each region and the equations to forecast equipment usage. The third section presents heating and cooling equipment prices, white the fourth section presents distribution system prices.

\subsection{Equipment Stze Models}

Usually, egripment is sized according to the peak load of a building rather than the annual loads. To investigate the relationship between the peak and annual heating and cooling loads, we used the DOE-2 building energy simulation model to develop thermal loads for a set of prototypes in each region. The prototypes differed in thermal integrity due to varying levels of insulation, infiltration, and so forth Based on the calculated peak and annual loads of the prototypes, we developed a simple linear relationship between peak load and annual load for each region with the following form:

$$
\mathbf{P}_{\mathrm{ith}}=\mathrm{b}_{\mathbf{L}}+\mathbf{m}_{\mathbf{T h}} * \mathbf{L}_{\mathbf{i} \boldsymbol{t}}
$$

where $P_{i r h}=$ predicted peak for prototype $i$, region $r$ and housing type $h(\mathrm{kB} w h)$,

$b_{r h}=$ estimated intercept term for peak equation,

$m_{r h}=$ estimated slope with respect to the beating or cooling load,

$L_{i s h}=$ calculated annual load for prototype $i$, region $r$ and housing type $h(\mathrm{kBtu})$.

We use a tinear relationship of this form for all fort housing types. We used single-family prototypes in estimating the parameters for single-family homes and manufactured homes, and multifamily prototypes to estimate the relationship for multifamily homes. Table 5.1 gives the resulting linear parameters for the determination of peak load for heating and cooling in the two regions, along with the $\mathbf{z}^{2}$ for the regression. The data and regression lines for the peak heating and cooling estimation are provided in Appendix $D$ for the two regions and two housing types (mobile homes are treated the same as single-family homes for the purpose of equipment sizing).

The high $\mathrm{r}^{2}$ for heating suggests that the relationship between annual and peak heating loads is quite strong, while the lower $\mathrm{r}^{2}$ for cooling shows that a linear relationship does not describe all the vatiation in peak cooling load. Peak cooling loads are more dependent than peak heating

${ }^{5}$ The one exception is room air conditioners, which ane usvally not sized fn nelation to the whole-house load, bot rather to provide a fixed quentity of cooling at peak perionds. 
loads on local extreme weather conditions, such as humidity, and on building geometry. Peak cooling loads can even be higher in a northern city such as Chicago than in a southern city such as Charleston. This means that there may be more uncertainty and variability in the sizing of cooling equipment. Thus while the heating parameters provide fairly robust estimates of peak loads for the two regions and the various prototypes, the parameters for cooling provide only rough estimates of the building peaks. The issue of sizing has important ramifications for the performance and cost of heating and cooling equipment under the design conditions of the assumed thermal shell. We will address some of these issues in Sections 6 and 7.

\begin{tabular}{|c|c|c|c|}
\hline \multicolumn{4}{|c|}{ 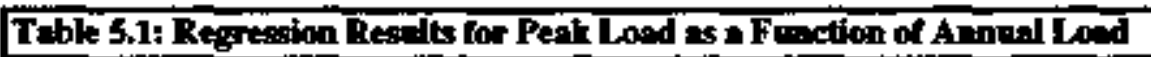 } \\
\hline Benting & 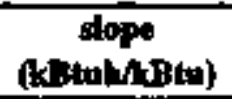 & $\begin{array}{l}\text { intercepk } \\
\text { (kAtul) }\end{array}$ & rsquinte \\
\hline $\begin{array}{l}\text { Noth Single-Family } \\
\text { North Multi-Fanily } \\
\text { South Singl-Family } \\
\text { South Multi-Family }\end{array}$ & $\begin{array}{l}0.423 \\
0.356 \\
0.662 \\
0.564\end{array}$ & $\begin{array}{l}7.917 \\
6.451 \\
8.563 \\
7.321\end{array}$ & $\begin{array}{l}099 \\
096 \\
1.00 \\
090\end{array}$ \\
\hline \multicolumn{4}{|l|}{ Dooling } \\
\hline $\begin{array}{l}\text { North Single-Family } \\
\text { North Multi-Family } \\
\text { South Single-Family } \\
\text { South Multi-Family }\end{array}$ & $\begin{array}{l}2.176 \\
1.568 \\
1.838 \\
1.642\end{array}$ & $\begin{array}{r}5.481 \\
3.251 \\
-11.447 \\
+8.321\end{array}$ & $\begin{array}{l}0.87 \\
0.65 \\
0.76 \\
0.53\end{array}$ \\
\hline \multicolumn{4}{|c|}{ 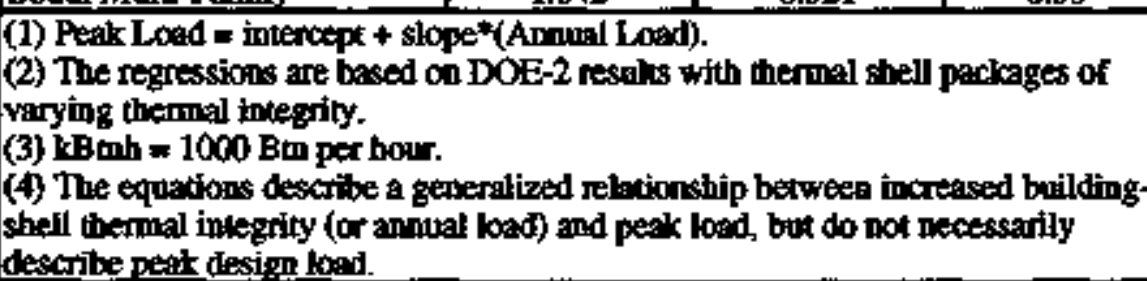 } \\
\hline
\end{tabular}

Besides being sized to meet the peak load, equipment is usually oversized to account for uncertainty in equipment perfomance and operating conditions that will actually be encountered once installed. Thus, to develop accurate sizing estimates we need to determine the degree to which equipment is typically oversized. In the absence of detailed capacity data from heating and cooling equipment installations, we must select the appropriate equipment size for each prototype in order to determine the average relationship between the peak loads of the prototypes and the size distribution of the shipments. We define two sets of criteria in correlating shells with equipment sizes. The first is to altempt to match, where possible, the size distribution of the shipments themselves. The second criterion is to chooge a set of sizing parameters such that the average size of the "sized" shells is equal to the average size in the shipment data itself. This latter criterion is actually a linear programming problem formulated as follows:

$$
\begin{gathered}
\text { Minimize }\left[S_{\mathrm{g}}-\Sigma\left(\mathrm{Z}_{\text {gh }} * \mathrm{P}_{\mathrm{igh}} * \mathrm{~W}_{\mathrm{igh}}\right)\right] \\
\Sigma\left(\mathrm{Z}_{\mathrm{gh}} * \mathrm{P}_{\mathrm{igh}} * \mathrm{~W}_{\mathrm{igh}}\right)-\mathrm{S}_{\mathrm{g}}>0 \\
\mathrm{q}_{\mathrm{L}}<\mathrm{Z}_{\mathrm{i}}<\mathrm{z}_{\mathrm{H}} \forall \mathrm{i}
\end{gathered}
$$

where $P_{i g h}=$ the predicted peak for shell $i$ and housing type $h$ for technology $g$,

$W_{i g h}=$ the share for shell $i$ and housing type $h$ for technology $g$,

$Z_{g h}=$ the sizing factor for technology $g$ and housing type $h$,

$S_{g} \quad=$ the shipment-weighted size for technology $g$.

$(z L, z H)=$ bounds on the sizing criteria. 
Application of this algorithm resulted in the sizing criteria shown in Tables 5.2.N and 5.2-S for the two regions. We had no data on the size of electric heating equipment, thus we chose the sizing for electric equipment based on typical practice (EPRI 1987).

\begin{tabular}{|c|c|c|c|c|}
\hline Eeating & S\&F & LSF & $\mathbf{M F}$ & MI \\
\hline Filectric Fumace & 183 & 1.83 & 1.66 & 1.81 \\
\hline Gas Furnace & 2.13 & 2.13 & 189 & 2.07 \\
\hline Oil Fundece & $2 x 2$ & 222 & 2.04 & 2.18 \\
\hline Dectuic Heal Prop & 1.46 & 1.46 & 1.53 & 1.62 \\
\hline Gas Hydronics & 2.41 & 2.41 & $2.0 \mathrm{I}$ & nfa \\
\hline Oul Hydronkes & 2.43 & 2.43 & 2.32 & na \\
\hline Flectric Room & 1.79 & 1.79 & 1.66 & 1.72 \\
\hline Gas Rocm & 1.63 & 1.63 & 1.66 & 1.61 \\
\hline Other Equipanent & 203 & 2.03 & 1,95 & 2.01 \\
\hline \multicolumn{5}{|l|}{ Cooling } \\
\hline Central Air & 103 & 1.03 & 0.84 & 1,07 \\
\hline Electric Heat Pump & 1.46 & 1.46 & 1.03 & 1.42 \\
\hline Room Air & 0.71 & 0.71 & 0.51 & 0.68 \\
\hline No Aii & & & & \\
\hline
\end{tabular}

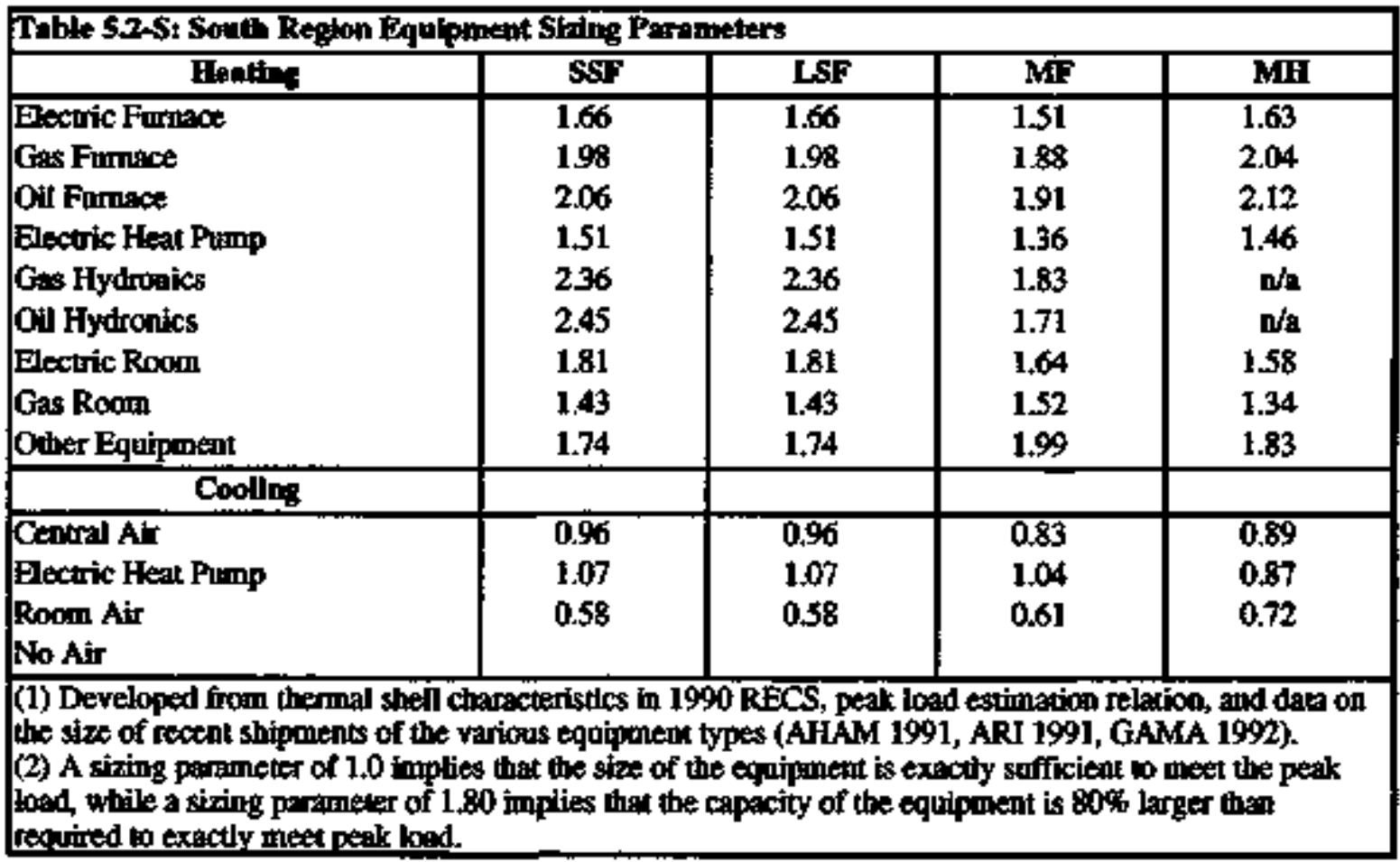

In actual practice, sizing factors vary considerably. One sizing study in Cleveland, Ohio, showed sizing parameters ranging from 1.0 to 7.0 (Dewerth 1991). Sizing of equipment may also depend on the energy conservation behavior of household occupants, such as night thermostat setback. Some analyses have shown that a nothern climate, the required equipment capacity for such scenarios may be greater than 3 times the peak load given constant thermostat setpoint (Hedrick et al. 1991). The equipment sizing model we estimate for REEPS is a combination of the peak load relationships from Table 5.1 and the equipment sizing parameters from Tables 5.2-N\&S. 
One mast bear in mind several methodological observations about the algorithms and criteria used in sizing HVAC equipment. First, the sizing is based on our two-region modeling framework A different number of regions would likely result in a rather different set of sizing parameters. Second, the sizing is based on the prototypes presented earlier in this report. $\mathbf{A}$ different set of prototypes, even with the same two regions (climates) could also result in different sizing parameters. Third, the methodology is aimed at calibrating two independent sets of data, namely the equipment size data and the thermal shell data, rather than predicting what the sizing will be for particular installations. While these distinctions limit the applicability of the sizing criteria to actual practice, the results are appropriate within the modeling framework because they maintain internal consistency among the components of the analysis - namely the shells, housing types and technology specifications.

\subsection{Unit Energy Consurnption and Usage Models}

In future years, the UECs must be updated to reflect changes in important parameters such as the building loads, fuel prices and the efficiency of new equipment. The analyst enters an equation for usage to specify these relationships. We chose the following form for this equation:

$$
\mathrm{UEC}_{\mathrm{ghs}}=\left(\frac{\mathbf{k}_{\mathrm{gh}}}{\eta_{\mathrm{s}}}\right) *\left(\frac{\mathbf{L}_{\mathrm{phs}}}{\mathbf{E}_{\mathrm{g}}}\right) *\left(\mathbf{P}_{\mathrm{g}}\right)^{\varepsilon}
$$

where

$$
\begin{array}{ll}
U E C C_{g h s} & =\text { UEC for techuology } g, \text { honsetype } h \text { and HVAC system } s, \\
L_{g h t} & =\text { Heating or cooling load, } \\
P_{g} & =\text { Foel price for technology } g, \\
\varepsilon & =\text { usage elasticity with respect to fuel price, } \\
k_{g h} \quad \text { = calibration nultiplier, } \\
\eta_{s} \quad \text { = distribution system efriciency, } \\
E_{g} \quad \text { equipment efficiency for teclunology } g .
\end{array}
$$

The usage equation is calibrated against the base year UECs (Tables 4.4-N\&S) to yield the calibration multipliers $k_{g} h$ for each technology $g$ and housing type $h$.

\subsection{Heating and Cooling Equipment Prices}

In the REEPS model, the purchase price of heating and cooling equipment is explicitly calculated for use in the new home equipment decision model. The purchase price of heating and cooling technologies is assumed to vary over time as a function of size and efficiency, relative to the base year. If we assume that $t=0$ represents the base-year, then the equation has the following functional form:

$$
P_{P_{t}}=\left(b+m *\left[S_{t}-S_{0}\right]\right) *\left(\frac{C_{t}}{C_{0}}\right) *\left(\frac{E_{t}}{E_{0}}\right)^{2}
$$

where

$$
\begin{aligned}
& P P_{f}=\text { equipment purchase price in year } t \\
& b \quad=\text { price at the base year size } S_{0} \text { and efficiency } E_{0} \\
& m \text { = price slope with respect to size, } \\
& S_{t}=\text { equipment size in year } t \text {, } \\
& C_{t}=\text { exogenous price moltiplier for year } t \text {, } \\
& E_{t}=\text { marginal (new equipment) efficiency in year } t \text {, } \\
& \varepsilon \quad=\text { elasticity of price with respect to efficiency, } \\
& S_{0}=\text { equipment size in base year, } \\
& C_{0}=\text { exogenous price multiplier in base year, } \\
& E_{0}=\text { marginal (new equipment) efficiency in base year. }
\end{aligned}
$$


As Equation 5.4 shows, the purchase price of equipment is assumed to vary linearly with size, and the equation reflects the parametric form of a line, anchored to the base size $S_{0}$ The average efficiency $E_{l}$ is for 1991 shipments, which is the first year of new purchases in the model. The base price $b$ gives the price of equipment at the base year size and efficiency. The slope describes the increase in price corresponding to a unit increase in size, measmred in kBtuh. Price is related to efficiency via the elasticity paraneter $\varepsilon$, which gives the percentage change in price corresponding to a percentage change in efficiency. The exogenous parameter $C_{t}$ is used as a price multiplier to allow the cost of a particular type of equipment to be reduced (or increased) in future years. One possible use of the parameter would be for a technology which is not yet mature, so that its price can be reduced as the technology nears full-scale production.

We used construction industry field estimates for cost data on heating and cooling equipment of different sizes (R.S. MEANS Co. 1991b, R.S. MEANS Co. 1991c) to estimate the parameters $b$ and $m$ in Equation 5.4. We used engineering-economic data for varying efficiency options (ADM 1987) in order to estimate the parameter $\varepsilon$ for each type of equipment. Since the data came from two independent sources, we combined the data to produce a single set of parameters for the functions. Since we are interested in the instalted purchase price of equipment (the price to the consumer), we assumed that each instalfation involved a main contractor and an HVAC subcontractor. We fit a linear regression for the price-size data and a non-linear regression for the price-efficiency data based on Equation 5.4. The details of these calculations along with the data and regression lines are given in Appendix E. Table 5.3 shows the resulting parameters for all equipment types and the regression $\mathrm{r}^{2}$ for the linear portion of the equation. No goodness-offit is provided for the non-linear regression because unlike linear regression, there would be no unique metric for this purpose.

\section{Distribution System Prices}

Distribution systems generally represent a substantial portion of the price of central heating and cooling systems; therefore the price of distribution systems is an important factor in the REEPS decision models. In our framework, there are two types of distribution systems, hydronic and forced-air. We developed prices for both types of systems based on engineering analysis of doct insulation prices (Andrews and Modera 1991) and construction field estimates (R.S. MEANS Co. 1991a). REEPS requires a linear relationship between distribution system price and floor area of the house $A_{h}$. We chose 1800 square feet as the base size for the linear equation since it is the dividing line between small and large homes (see Section 2.2). The regression parameters we estimated are shown in the following equation for distribution system price:

$$
\begin{aligned}
& \text { Forced-Air Systems: Price }=\$ 2998+0.842 *\left(A_{h}-1800\right) \\
& \text { Hydronic Systems: } \quad \text { Price }=\$ 3508+1.485 *\left(A_{h}-1800\right)
\end{aligned}
$$

Equations 5.5 and 5.6 yield the purchase price of the distribution system for a house of any floor area $A_{h}$. The distribution system costs are part of the total HVAC system prices and are therefore included when comparing the prices of different systems to determine future market shares, as will be discussed in Section 6.3. 


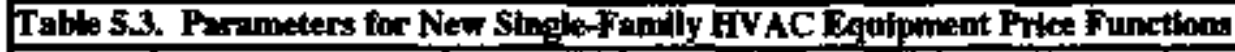

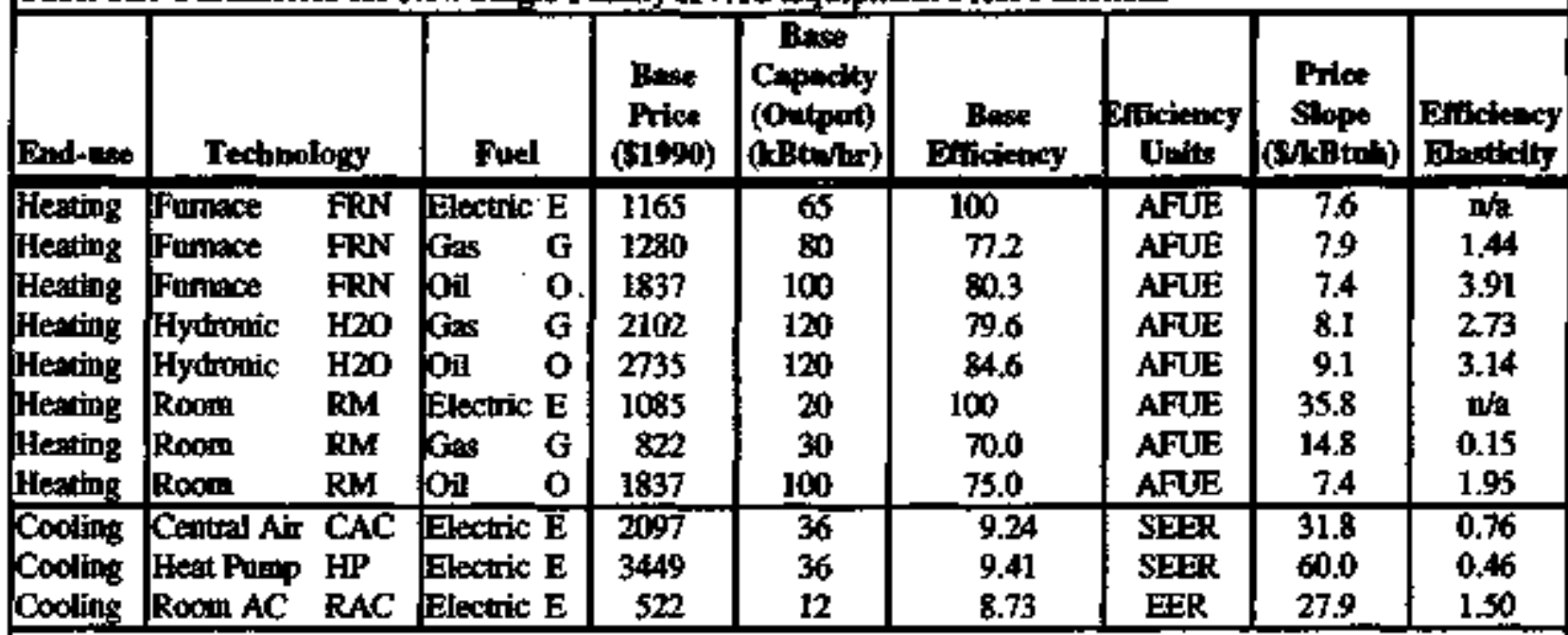

The Purchase Price of Equipment is a finction of Capacity and Eficiency acoording to the following equation: Prke $=(b+m *[C-C l]) *(E / E 1)$ eff

where:

$$
\begin{aligned}
& b=\text { Price a Base Canecity and Efficiescy (\$) } \\
& \text { m = Price Slope (SMBmhr) } \\
& C=\text { Equipment Capacity (Outpat, kBn//rr) } \\
& \mathrm{CI}-\mathrm{Base} \text { Capecity (O-1Lut, tB. Bufhr) }
\end{aligned}
$$

$$
\begin{aligned}
\text { E } & =\text { Etquip.ment Efficiency } \\
\text { E1 } & =\text { Base Efticiency } \\
\text { eff } & =\text { Elasticity of price with respect to efficiency }
\end{aligned}
$$

(1) Heat pinp (HP) costs are based on dath for spilt systens. Hydronic ( $\mathrm{H} 2 \mathrm{O}$ ) costs are based on data for hot water bo:lers. Electric room (E RM) costs are based on data for electric baseboirds, with increasing capacity from adding atditiond baseboards.

(2) Bose cost, cupacity, mol cost vs. capacity relationship from MEANS 1992 residential and mechanical cost data (R.S. MEANS Co. 1991b, R.S. MEANS Co. 1991c). Converted to 19905 using the prodncer price index Costs inclnde installation but not thermal distriluetion sysiem.

\begin{tabular}{|c|c|c|c|c|c|c|c|c|}
\hline \multirow[b]{2}{*}{ End-rst } & \multirow[b]{2}{*}{ Sratem } & \multirow[b]{2}{*}{ Technology } & \multirow{2}{*}{$\begin{array}{c}\text { Rerting } \\
\text { Fwol }\end{array}$} & \multicolumn{2}{|c|}{ Outrot Capecty (1) } & \multicolumn{3}{|c|}{ Efticioncy } \\
\hline & & & & Lotwer & Upper & Lomer & Dpper & Units \\
\hline Heating & Forced Air & Fumace & Electric & 30 & 131 & na & $\mathbf{n} \mathbf{a}$ & n/a \\
\hline Heating & Forced Air & Fumpice & Gas & 42 & 160 & 62 & 92 & AFUE \\
\hline Heating & Forced Air & Fumace & Oil & 55 & 200 & 80 & 91 & AFUE \\
\hline Heating & Hydronic & HW Boiller & Gas & 80 & 203 & 68 & 90 & AFUE \\
\hline Heating & Hydronic & HW Boiler & Otl & 109 & 236 & 82 & 89 & AFUE \\
\hline Heating & Room & Baseboend & Electric & 8 & 38 & n/a & nfa & $\mathbf{n} / \mathbf{a}$ \\
\hline Heating & Rocm & Furace & Gas & 18 & 50 & 73 & 80 & AFUE \\
\hline Heating & $\mathbf{R o O m}$ & Heater & O여 & 24 & 94 & 64 & 87 & AFUE \\
\hline Cooling & Foroed Air & Central Air & Flectritc & 24 & 60 & 70 & 14.1 & SEER \\
\hline cor & Forced Air & Heat Pump & Electric & 18 & 60 & 6.8 & 147 & SEER \\
\hline & Room & Room Air & Electric & 6 & 21 & 9.3 & 13.5 & EER \\
\hline
\end{tabular}

(3) Cost vs efficiency relationship from ADM (1987). Converted to 19905 using the producer price index.

(4) Base efficiency and capacity are not eecessarily the typical efficiency and capacity of curreat units, and ane outy used at a refertice point for cost pumposes.

(5) HP base mit HSFF is 7, and this parameter scales more or less linearly with SEER. The relationship is not exact, bat it is rougbly accurate.

Vald Ronges for Equipoment Coet Funclions 


\section{DECISION MODELS}

Consumers must make several decisions regarding the purchase or upgrading of heating and cooling equipment. In residential end-use forecasting, these decisions are generally grouped according to the system being purchased and the relevant energy efficiency attributes of that system. The HVAC model of REEPS actually has three distinct types of decision models corresponding to three types of consumer choices. The first is efficiency choice, which refers to the level of efficiency chosen by the consumer for a particular type of heating or cooling equipment. The second is the choice of a particular HVAC system, based in this analysis on the combinations detailed in Section 4. The third type of consumer choice is the decision of thermal shell package for new homes, using the packages we defined in Section 3.3. These decisions are of course related to each other and, in the course of the forecast, REEPS iterates to bring the decision models together in a consistent fashion (McMenamin et al. 1992).

We developed decision models for the first two of these types of decisions. These models are based on the theory that consumers make tradeoffs between purchase price and operating expense in their purchase decisions. This tradeoff is captured through explicit calculation of a vtility function for each type of equipment and/or housing type. The utility functions are used in a multinomial logit framework to represent consumer choice and forecast martet shares. In the following sections, we describe the methodology used to develop the decision models and present the estimated parameters for these decision models. Section 6.1 outlines the general framework for all three decision models in REEPS and shows the calculation of the two basic attributes - purchase price and operating expense - to be used in each model. Section 6.2 explains the methodology and results for the efficiency choice model parameters. Section 6.3 details the estimation of market share parameters for HVAC systems in new homes. Section 6.4 discusses the market share analysis for thermal shell choice.

\subsection{Decision Model Framework}

The multinomial logit model for the decision models is derived from the theory of "qualitative (or "discrete") choice analysis." We use a standard model of consumer choice, involving the implicit tradeoff between present purchase price and future operating expense (Train 1986). Confronted with $j$ discrete purchase options, a consumer selects the option that maximizes utility as a function of purctiase price (PP) and operating expense (OC), as well as other factors. If one assumes a linear utility function (which is a standard practice), then the vility of option $j$ can be represented as:

$$
\mathrm{U}_{\mathrm{j}}=\beta_{1} \mathrm{PP}_{\mathrm{j}}+\beta_{2} \mathrm{OC}_{\mathrm{j}}+\alpha_{\mathrm{j}} \quad \forall \mathrm{j}
$$

where $\beta_{1}, \beta_{2}$ and $\alpha_{j}$ are unknown parameters to be estimated. In this specification, utility is presumed to decrease with an increase in either cost, so that $\beta_{1}$ and $\beta_{2}$ are expected to be negative. The constant $\alpha_{j}$ is supposed to account for those attributes of option $j$ that affect the consumer's decision but are unobserved. In this model, the ratio of the two parameters $\beta_{1}$ and $\beta_{2}$ represents the marginal rate of substitution between the two elements of purchase price and operating expense, commonly interpreted as the implicit discount rate $r$ if the devices or systems are assumed to have infinite lifetime:

$$
\frac{\beta_{1}}{\beta_{2}}=\mathrm{r} \text {. }
$$

If the devices or systems have a finite lifetime of $T$ years, we can interpret the parameters similarly by calculating the value of $r$ that satisfies the following relationship:

$$
\frac{\beta_{1}}{\beta_{2}}=\frac{r}{\left[1-(1+c)^{-T}\right]}
$$


We report the implicit discount rate for each decision model estimated in this analysis. These discount rates are provided mainly as an intuitive interpretation of the logit parameters and should be used with caution if transferred to other consumer choice models, such as life-cycle cost minimization models.

The utility function in Equation 6.1 is used to predict the shares or probabilities of particular options in a given year $t$ based on the standard multinomial logit formulation:

$$
\text { Probability of Ownership }{ }_{h, j}^{t}=\frac{\exp \left(U_{h, j}\right)}{\sum_{j} \exp \left(U_{h, j}\right)}
$$

where $h$ is the housing type, $j$ is the option of interest, $j^{\prime}$ is the set of all options, and $U$ is the "utility function" or "desirability index" in any given year $t$. For the reader interested in more detail on the nature of qualitative choice analysis and its implications for decisions on investments in energy efficiency, we have provided a detailed discussion in Appendix $\mathbf{G}$.

Accurate estimation of the parameters $\beta_{1}, \beta_{2}$ and $\alpha_{1}$ requires detailed price data on purchase decisions at the individual or household level. Unfortunately such data do not typically exist at the national level. One option is to use data collected at the regional level on individual purchase decisions, such as utility data collected from rebate programs. Another option is to use aggregate and averaged national data to characterize overall market outcomes. We choose the option of basing our analyses on aggregate national-level data, and we segment the data accordingly. We develop price estimates using the price parameters from Section 5 for HVAC equipment, distribution systems and the thermal shell.

In actual practice, there exist many other relevant attributes in these decisions beyond operating expense and purchase price. The practices and recommendations of contractors in the HVAC market will certainly have a significant effect on the choices made. The clarity with which the products are displayed or advertised will impact the ability of consumers to detemine the cost tradeoffs involved. The occupancy patterns and conservation behavior of the households can alter their operating expenses. The pricing strategies of manufacturers may result in considerable variation in the prices of more efficient equipment. Such complexities can be explicitly included in the model by adding additional $\beta_{j}$ terms, or can be implicitly represented by the $\alpha_{j}$ term in Equation 6.1. The standard practice in discrete choice analysis, however, is to exclude these additional factors due to a lack of data with which to estimate them. We adopt this practice in this analysis, excluding all other factors besides purchase price and operating expense. In doing so, we conduct our analyses as if the market behaves according to this simple tradeoff ${ }^{\text {. }}$. Thus we are able to make explicit our assumptions concerning the behavior of the market for energy efficiency. The two-attribute model (Equation 6.1 without the $\alpha_{j}$ term) becomes a proxy for the more complex workings of the marketplace. Fortunately, heating and cooling equipment have no real frills like some appliances and their value is generally based on the ability to reliably deliver heating or cooling services at lowest cost. This suggests that the two-parameter HVAC decision models offer a reasonable depiction of the marketplace (Rudernan et al. 1987).

\footnotetext{
6 In owr framewot, the "consumer" or "decision maker" does not refer to specific purchiasers or types of punchasers such as a bomeowter or contractor, but instear represents the behavior of the martet for HVAC equipment in the afgregate, with scme segmentation by housing type. Consequenty the consumer represents that econontic agent who best chacacterizes the market for each equipment and/or system type considered.
} 


\subsection{Efiticiency Choice}

In the residential forecasting framework, honseholds face decisions about what levet of efficiency they choose for a given type of equipment .. a choice that could be influenced by many factors. These factors include the design heating or cooling load of the boilding, the current foel prices, the number of people in the housebold, and the expected conservation practices of the household. The REEPS HVAC module cucrently does not model these HVAC equipment efficiency choices in the same way as the REEPS appliance model -- with discrete efficiency options for HVAC equipment and a logit efficiency choice model to fonecast market shares. Rather, average efficiency levels are forecast for each HVAC equipment type, based on an exogenous time series of average efficiency values (driven by Federal appliance standards) modified by a fuel price elasticity, as shown in Equation 6.5:

$$
\mathrm{Eff}_{g}^{t}=\mathrm{ExogE}_{g}^{t} \times\left(\text { FuelPrice }^{t}\right)^{\varepsilon g}
$$

where Eff is the forecast efficiency of equipment type, $g$, in year, $t$, ExogEff is an exogenous time series of average efficiencies for equipment type, $g$, and $\mathrm{gg}$ is the tuel price elasticity for equipment type, $g$. We adopt this reduced form efficiency choice model for our baseline analyses using REEPS. For use in this modeling framework, we have re-estimated the fuel price elasticities of each equipment type, as shown in Table 6.1.

\begin{tabular}{|c|c|}
\hline Heoting (Screen HV.(ic1) & Fuef Price Elasticity \\
\hline Electric Furnace & [a \\
\hline Gas Furnace & 0.13 \\
\hline LFG Fumace & 0.15 \\
\hline Oil Fumace & 0.14 \\
\hline Electric Heat Pump & 0.16 \\
\hline Gas Hydronics & 0.13 \\
\hline Oil Hydroenics & 0.14 \\
\hline Electric Room & na \\
\hline Gas Room & 0.10 \\
\hline Other Equipmext & 0.10 \\
\hline \multicolumn{2}{|l|}{ Coothing (Scrath HV-6t2) } \\
\hline Central Air & 0.15 \\
\hline Electric Heat Pump & 0.15 \\
\hline Room Alt & 0.10 \\
\hline \multicolumn{2}{|c|}{ 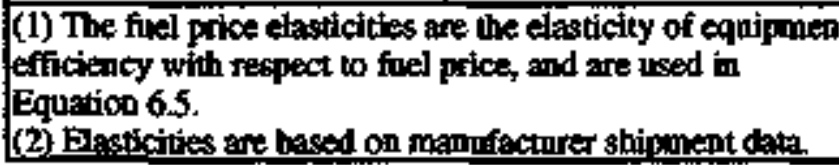 } \\
\hline
\end{tabular}

For analyses requiring more detailed modeling of efficiency choice, such as impact analysis of Federal appliance standards, we have developed a specific efficiency choice model (implemented in a spreadsheet) to forecast the exogenous time series of equipment efficiencies described above (the ExogEff vatiable). The model contains two parameters of the form described in Section 6.1. To estimate the model parameters $\left(\beta_{1}\right.$ and $\left.\beta_{2}\right)$, we use the data on equipment market share by efficiency, discussed in Section 4.3. The efficiency distribution data allow us to segment the shipments into several discrete efficiency levels (or bins). Each bin represents a grouped data set, which is in tum represented by an option $i$ having the average efficiency level of its respective bin. For each option $i$ we calculate its market share $M_{i}$, purchase price $P P_{i}$, and 
operating expenses $O C_{i}$. First, the size is determined from the sizing parameters and shell assignments given in Section 3.3. The purchase price of equipment is determined from the price formulae in Table 5.3 for each efficiency level $i$ and for each technology. The operating expense for efficiency level $i$ is simply a function of fuel price and unit energy consumption (which is in tum a function of the efficiency of option $i$ ), as shown in the following equation:

$$
O C_{i}=U_{E C} * P_{f u x i} \text {. }
$$

To estimate the model parameters, we used a least squares procedure developed by Berkson and described by Ben-Akiva and Lerman (1985). Berkson's procedure is based on the fact that a multinomial logit model with a linear-in-parameters utility function can be transformed into a form amenable to standard regression techniques. The MNL equation is transformed as follows:

$$
\log \left(\frac{S_{j}}{S_{j}}\right)-\beta_{1}\left(P_{1}+P P_{j}\right)+\beta_{2}\left(O C_{-}-O C_{j}\right)
$$

where $j$ is a chosen option used for nomalization. The transformed data allow the logit model parameters $\beta_{1}$ and $\beta_{2}$ to be calculated using linear regression methods, albeit with the loss of one degree of freedom statistically due to the normalization. For each technology, we calculated the model parameters using 1990 fuel prices. The parameter estimates and associated implicit discount rates are shown in Table 6.2.

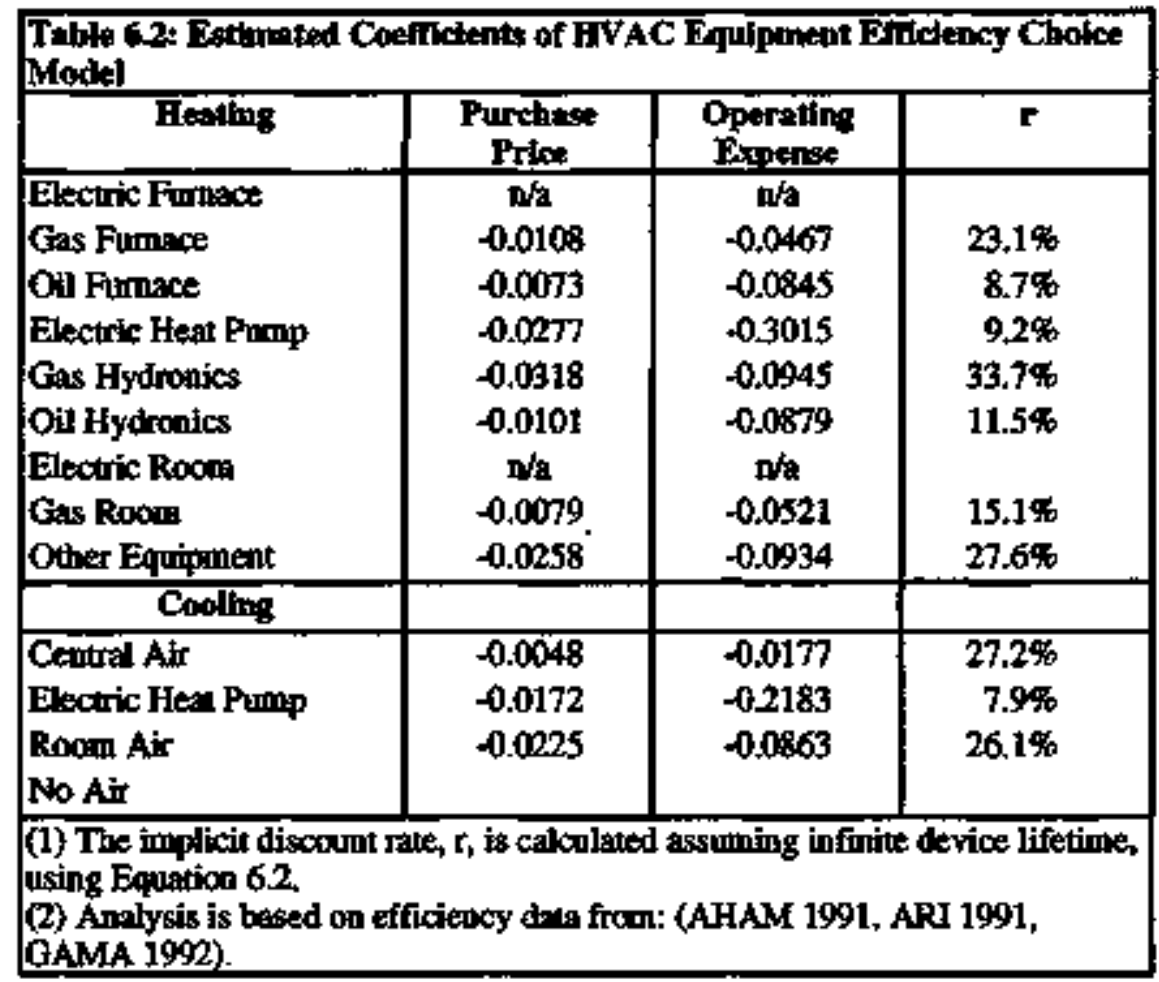

One should bear in mind a few important points about our methodology and the resulting parameter estimates. First, this methodology is quite different from some calculations of the implicit discount rate, such as those based on life-cycle cost minimization (Rnderman et al. 1987). This is because the qualitative choice motel framework requires no assumptions about life-cycle cost. Even where the results of the two methods are in reasonable agreement, this does not mean that the models themsetves are interchangeable. ${ }^{7}$ Second, the implicit discount rates

${ }^{3}$ A simple explanation of the differences between the two approaches cen be glesped from the fact that hife-cycle cost minimization methods focus on the average efficiency whereas the qualitative choice model requires a set of 
we calculated cannot be used directly in other modeling frameworks. The estimated parameters $B_{1}$ and $\beta_{2}$ must be used directly in the same mathematical formulation specified if they are to retain any significance. The implicit discount rate is simply a derived quantity useful in interpreting the results, not a model result in and of itself.

\subsection{New Home HVAC System Choice}

The choice of HVAC system typically involves two decisions - one for the type of heating equipment and the second for cooling equipment. Thus the multinomial logit model to represent these decisions requires two levels, otherwise known as a "nested" logit, which is the form expected in REEPS. The nested logit in tum requires specification of two utility functions. One is for the "upper level" cooling choice and the other is for the "lower level" heating choice. The complete model is estimated in a sequential or "two-level" manner, starting with the lower heating choice level. Curently, data limitations (described below) prevent estimation of the full HVAC nested logit. Due to insufficient data to estimate the cooling choice, we have adopted the default parameters for cooling choice from the REEPS HVAC modale (Goet 1990), as shown in Table 6.3. The available data allow calculation of a national heating-choice model, which we discuss in this section, as well as a two-region heating-choice model, which we discuss in Appendix F. These new heating system parameter estimates are combined with the REEPS default cooling system parameters to rum the REEPS HVAC model.

\begin{tabular}{|c|c|}
\hline Equipanent Type & Utilty Function \\
\hline Central Aif & 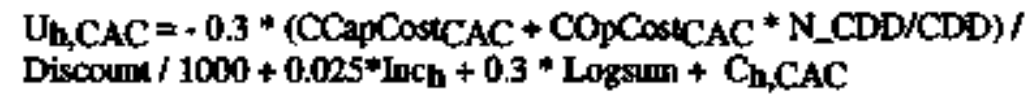 \\
\hline No Central Aîr & 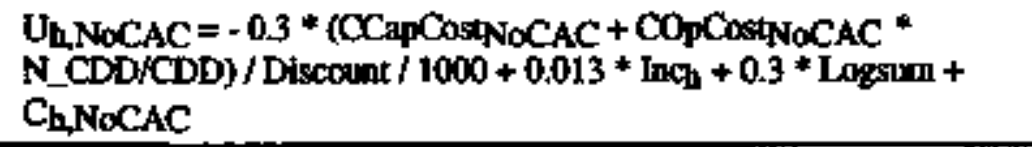 \\
\hline \multicolumn{2}{|c|}{ 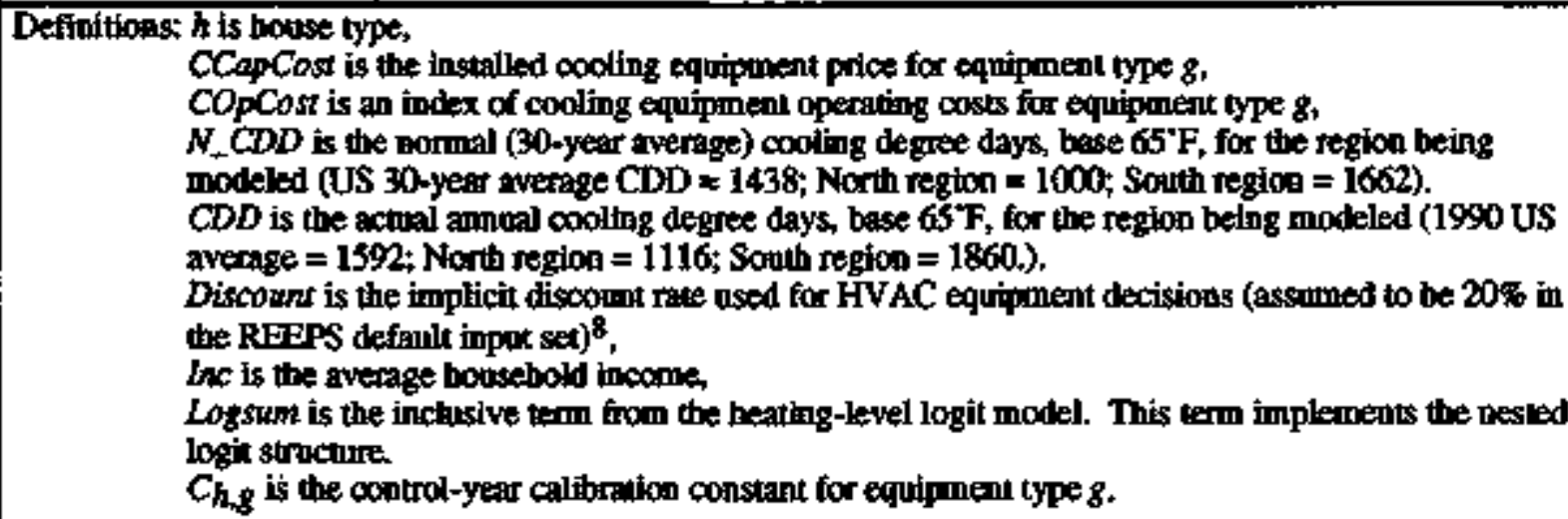 } \\
\hline \multicolumn{2}{|c|}{ 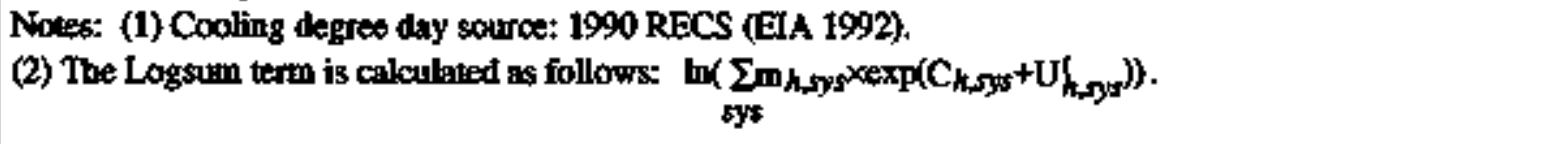 } \\
\hline$s$ an 9 & 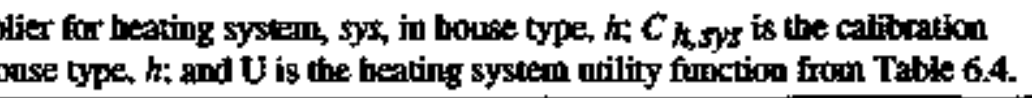 \\
\hline
\end{tabular}

Observetions, or in orr case, a distribution In cases where the average efficiency does not describe this disuribution well (i.e., it is bighly asymmetric), then the reselts of the two methods may differ considerably doe to the non-finear nature of the model.

${ }^{8}$ Note that this discoumt rate is for the HVAC ownerstip modet and is fistinct from the "market discount me" used to characterize the efficiency choices. In practice, the REEPS defanlt exuipment chotoe models are relatively 
To estimate logit parameters, one typically uses random samples of individual purchases, and indeed, the logit model was designed for use with data in this form. In our case, however, only aggregate (and averaged) data were available. We developed 10 data sets in order to create the national version of the HVAC market share decision model, with each data set corresponding to equipment choices in one of the ten federal regions. In this section, we review the data and procedures for the four basic aspects of model development: raarket shares of HVAC systems, thermal shells, equipment characteristics and cost estimates.

\section{Market Shares of HVAC Systems}

We used survey data from the National Association of Home Builders (NAHB 1989) for the market data in the analysis. The data were for single-family detached homes by state and by HVAC system category. Eight types of HVAC systems (combined heating and cooling equipment) were represented, composed of seven types of heating and two types of cooling equipment. The heating technologies included electric furnace, gas fumace, oil furnace, gas hydronic, oil hydronic, electric room, and electric (air source) heat pump. Gas furnaces were further segmented into homes with Central Air Conditioning (CAC) or Room Air Conditioning (RAC), to yield eight HVAC systems. We aggregated the data based on the ten Federal regions and the eight HVAC system types, resulting in a total of 80 grouped data points.

\section{Thermal Shells}

For each Federal region, we chose the city with the climate closest to that of the populationweighted average from the GLOM program (Andersson et al. 1986). We developed a set of hearing and cooling loads for each city by using component loads (Hanford et al. 1994). We determined the component levels (insulation levels, windows, etc.) based on the averages for each grouped data point from the NAHB data set. We calctilated the annual heating and cooling loads for the 80 data points based on the component loads, component levels, and the floor areas available in the NAHB data. These calculations are identical in form to those described in Section 3.2 and Appendix A.

\section{HVAC Eguipment Characteristics}

Equipment characteristics used to estimate the decision model include the efficiency, size (capacity), and Unit Energy Consumption (UEC). No regional data were available for equipment efficiency, so we used the average efficiencies for 1987 shipments for each type of equipment. The equipment size was based on the calculated peak load and the sizing parameters for each equipment type. The sizing methodology is identical to that used for the two region model, as described in Section 5.1. The Unit Energy Consumption is calculated using Equation 5.3, with the fuel price elasticity set to 0 . For the distribution system efficiency, we used estimates for new 1990 homes (Hanford et al. 1994) as none were available for 1987.

\section{Price and Operating Expense Estimates}

The price and operating expense data needed for model estimation include the purchase price of heating equipment, purchase price of the distribution system and the annual heating equipment operating expense. Equipment purchase price depends on equipment size and efficiency according to Equation 5.4, using the parameters provided in Table 5.3. We also added a regional price multiplier to this equation to account for differences in price levels between regions (Boghosian 1991). Distribation system price is based on square feet of floor area and system type, as given in Equations 5.5 and 5.6. Annoal operating expense is simply the Unit Energy Consurnption multiplied by the fuel price. We developed regional fuel price data from fuel prices reported by state for the residential sector (US DOE 1989a). The Federal Region-level

insensitive to the discoumt rate, so the 20 \% discount rawe has been selected to be generally representative of the market discount rates observed in the HVAC end-uses. 
fuel prices are averages of the state-level fuel prices weighted by the number of households in each state (US Burean of the Census 1992).

\section{Model Estimation}

As described in Section 6.2, Berkson's procedure simplifies the estimation of logit parameters using grouped dath, thus we employed this method to estimate the HVAC equipment choice parameters. First, the equipment prices were nomalized to the annual losds. For example, a gas furmace with purchase price of $\$ 2000$ in a region with a heating load of $100 \mathrm{MBn} /$ year would have a normalized purchase price of $2000 / 100=\$ 20 / \mathrm{MBtu}$. Previous snidies have found that such a nomalization is necessary to obtain reasonable estimates (Dabir 1985, Goett 1990). The equipment price and market share data are then nomalized to a chosen option, as shown in Equation 6.7. The resulting parameters are shown in Table 6.4. Previous estimates of the implicit discount rates associated with heating choice have varied widely, from less than $4 \%$ to over 50\% depending on the data as well as the model specification (EPRI 1988). Our model estimate is consistent with this established range.

\begin{tabular}{|c|c|}
\hline Parombler & Porameter Estimate \\
\hline 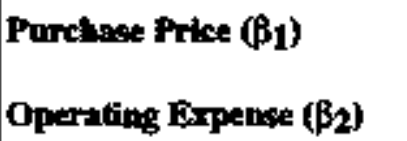 & $\begin{array}{l}-0.0024 \\
-0.0051\end{array}$ \\
\hline Inplicik Discomet Rete (r) & $47.3 \%$ \\
\hline \multicolumn{2}{|c|}{ 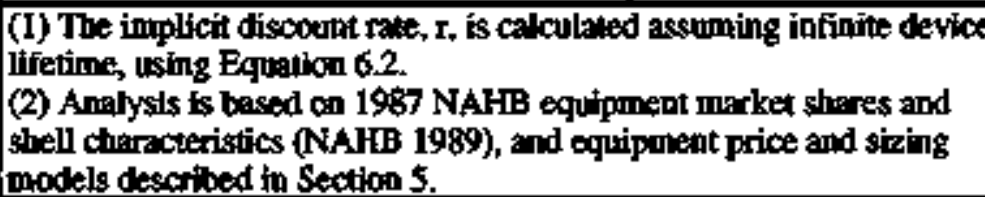 } \\
\hline
\end{tabular}

These parameters only apply to heating equipment choice and not to the choice of cooling equipment. The data were not sufficiently varied nor detailed enough for the cooling estimation. with the result that the cooling parameters did not converge to negative values, which is a necessary condition for consistency in the model. Thus, we rely on the default cooling choice model, as described above.

We also estimated separate single-family heating equipment choice models for both the north and south regions, which are documented in Appendix $F$. The national equipment choice model prestented above provides more robust results for national-level forecasts, due to more extensive data and a more accurate estimation technique. However, the regional equipment choice models may be preferred for cases where regional differences in equipment choice are important.

One should bear in mind that the equipment choice models documented in this report are based on data for equipment purchases in new single-family dwellings. Their application to other housing types and replacement purchase decisions may not produce reliable results. However, data limitations (specifically, a number of zero market shafes for certain equipment types in the 1990 RECS dataset) do not allow estimation of heating equipment choice models for the other dwelling types (multifamily atd tobile bome). The estimation of replacement equipment choice models is similarly hampered by a lack of purchase data. Until better data are available, we believe that the best approach is to use the single-family equipment choice model for all housing types. 
Finally, we have found that the allocation of system distribution prices in the central air options has a significant impact on the estimates. In our judgment, these prices are most sensibly assigned to the "upper," cooling-choice level in the nested logit model. However, removing them from the central air-contingent heating system data results in implicit discount rates of several hundred pencent. Moreover, REEPS is structared with these distribution prices assigned to the heating level. Accordingly, our parameter estimates for single-family dwellings have been estimated with these distribution system prices included in the heating system price variables. For this reason, when these parameters are used in REEPS, the logit equation should include the combined heating and distribution system price variables (HCAPCOST + DISTCOST) and exclude the cooling and shell price variables (CCAPCOST and SHELCOST).

\subsection{New Home Thermal Shell Choice}

We adopted the REEPS default thermal shell choice model (McMenanin et al. 1992) at the present time because the thermal shell data to which we had access were not sufficiently disaggregated to allow the estimation of logit models for thermal shell choice. This default model simply applies a 20\% discount rate to the Life-Cycle Cost (LCC) decision annong the available themal shell packages. There is no differentiation among different shell groups or housing types in this model. The simplicity of this model should not lead to inaccurate results, however, because during the REEPS calibration process the themal shell decision model will automatically be calibrated to the control values for new home thermal shell market share, which were given in Tables 3.5-N and 3.5-S.

\section{FUTURE WORK}

Doe to data, software and/or resource limitations, we were unable to incorporate some features into the model. We discuss these future work areas in this section.

\subsection{Reom Aír Conditioners}

We currently treat room air conditioners as a subset of homes without central air conditioning. We did not include a room air conditioner system type in the primary cooling options in order to limit the number of combined beating and cooling systems. For this reason, the upper level of the HVAC equipment logit model chooses between central air or no central air, and noom air conditioner ownership is forecast by a simple saturation model in the secondary cooling equipment module. This treatment of room air conditioners as a secondary cooling system iruposes several linitations on forecasting changes in the room air conditioner end-use. As mentioned, the ownership model is not a discrete choice model. Most importantly, REEPS does not endogenously forecast changes in secondary equipment efficiency or capacity. Thus, both the saturation and UEC of room air conditioners is fairly constant over time. One possible solution is to treat room air conditioners as an appliance in the REEPS appliance module. This is an intuitively appealing method because room air conditioners tepd to be purchased and operated more like appliances rather than HVAC equipment. This formulation would recuitire changes in the REEPS code to access variables from the HVAC module.

\subsection{Common heating systems}

Mnltifamily buildings are often more difficult than single-family buildings to analyze in an enduse forecasting framework because they include many different types of buildings, some of which have common heating and cooling systems for a building or part of a building. It becomes more difficult to interpret the energy characteristics and the economic tradeoffs in such cases both becanse of physical differences in the equipment and the fact that these consumers have no control over the choice of heating and cooling systems except in limited cases where a building is co-owned by its occupants. We would like to better characterize buildings that have common 
heating and cooling systems in the REEPS HVAC model. We plan to investigate the detail and availability of datta and consider two possibilities for improving the representation. One method is to create a separate housing type for buildings with common systems and adjust the struxture accordingly. Another possibility is to create separate equipment types for conmon heating systems and assign them to the share of multifamily boildings which have common heating systems, which could be estimated from the 1990 RECS.

\subsection{Thermel Shell Retrofits}

The REEPS thermal shell retrofit module has three significant linitations: 1) the default retrofit dexision model is a simple life-cycle cost model, 2) new construction shell costs are used to model shell retrofits, and 3) themal shell costs do not vary by housing type. We have not been able to obtain data on retrofit activity with which to specify the thermal shell retrofit decision model in REEPS. At a minimum, we would need household or grouped data which gave some indication of the thermal shell components before and after the retrofit. One possible method of obtaining these data would be to determine a subset of households common to both the 1987 and 1990 RECS in which retrofits were undertaken. The rates of retrofit activity could then be used in concert with our data on retrofit costs in order to develop some rough parameters for a conversion decision model. To solve the second and third limitations of the retrofit model will require changes to the REEPS computer code.

\section{7,4. The Rebound Efiect}

When consumers purchase more efficient equipment, they sometimes change theit behavior because their marginal cost of additional energy services has decreased. We would like to determine the size of this effect for the purpose of incorporating these behavioral changes into the models of energy usage in the HVAC model of REEPS. A simple elasticity parameter could be used in the usage Equation 5.3 to represent the percentage increase in consumption resulting from a percentage increase in efficiency. This would require metered household energy use data both before and after the change in equipment. The household data would have to include equipment nameplate data or give the capacity and efficiency of equipment in each case. Ideally, we would look at only those cases where the same type and size of equipment was chosen, with the only difference being the efficiency of the equipment.

\subsection{Eiticiency Choice}

We depicted efficiency choice for the average loads based on thermal shells for three types of heating: electric resistance, heat pump, and fuels. This means that the operating expense was based on the average UEC detemined from the average load. As with many aspects of this type of modeling, average data can cause erroneous and misleading results. In this case, the discrepancy stems from three simple facts: (1) the decision model for efficiency choice depends directly on the load, via the UEC, (2) the decision model is redaced-form for HVAC equipment, and (3) the decision model is nonlinear. This means that as the load diverges from this average due to changes in thermal shell market shares, the decision model becomes less and less appropriate. We need a means of estimating this divergence for all the relevant factors, which include other variables such as the exogenous cost multiplier and the sizing assumptions. There are two ways in which we conil correct for this error. One is to seek a change in the REEPS software which will allow specific options and a multinomial logit model for HVAC equipment. The' second way is to develop correction factors by iterating over many combinations of attributes, calculating the efficiencies, and estimating the gap between the reduced-form result and the iteratively predicted result for efficiency choice. 


\subsection{Passive Solar Features}

We have not considered passive solar features in configuring our thermal shells for the model and would like to develop a structure for doing so. The current framework in REEPS makes it possible to develop such features by treating them as distinct thermal shell components. In order to implement the featores, we would need to gather price data, do themal simulations, and incorporate a separate shell type for systems which have the features. We could then develop a decision model for choices which include the passive solar feanures.

\subsection{New Technologies}

With the exception of our configuration of windows in the thermal shell section, we have only included mature technologies in our model. We would fike to consider emerging technologies which coutd play an important role in reducing space conditioning energy consumption in the coming decades. Some of these technologies would be: natural gas heat pumps, ground source heat pumps, evaporative cooling, ductless air conditioning and heat purnps, and integrated space heating/water heating systems. In order to incorporate these designs into the model, we will need price data for different designs, performance and operating characteristics and data on the capacity and efficiency of the models currently being sold of designed. Since REEPS is quite flexible in configuring technologies, incorporating most technologies into our model is limited only by the availability of the price and design data. Some technologies, such as integrated space/water heating systems, will require changes to the REEPS code to allow feedbacks between the HVAC and appliance modules.

\subsection{Thermal Distribution Systems}

REEPS cumently does not explicitly treat the efficiency of thermal distribution systems (ducts and hydronic piping). This is an important element in the HVAC module, however, because neseanch has shown that typical thermal distribution systems may be only $60-70 \%$ efficient (Andrews and Modera 1991). REEPS implicitly accounts for this effect during the base year UEC calibration process, but wo would like to directly incomporate thermal distribution efficiency into the UEC equation, in order to model policies aimed at improving duct efficiency. This would require a thermal distribution system efficiency choice model, and feedback of the resulting efficiencies into the UEC equation.

\section{\& CONCLUSTONS}

The report illustrates the diverse set of techniques and data sources required to configure an enduse forecasting model. We defined the thermal shells, configured heating and cooling equipment, developed equipment size, usage and price equations, and estimated decision model parameters to forecast consumer choices. The report also demonstrates the complexity and interdependence of the space conditioning end-uses and the fact that differences in methodology can have significant impacts on the results. The proliferation of models and model parameters and the lack of detailed documentation in this area have been sources of considerable confusion for practitioners and policy-makers alike. By making explicit the data and assumptions behind the analysis, we seetk to clear up some of this confusion and move the debate beyond simply the numerical results of the models. This should permit researchers and policy makers to focus on important methodological and data issues which provide the proper context in which to consider the numerical results. While this report will be of most interest to practitioners in the area of residential end-use forecasting, it also provides important background for policy makers interested in addressing detailed programs and issues. 


\section{REFERENCES}

ACCA. 1975. Manual J: Load Calculation for Residential Winter and Summer Air Conditioning. Air Conditioning Contractors of America (Formerly National Envitonmental Systems Contractors Association), Washington, DC. Fourth Edition.

ADM. 1987. Costing Analysis of Design Options for Residential Appliances and Space Conditioning Equipment. Arthur D. Little Associates, Inc., Sacramento, CA. December.

AHAM. 1991. Room Air Conditioner Data. Association of Home Appliance Manufacturers, Chicago, IL. July 17.

Andersson, Brandt, Wiltiam Carroll and R. Martin Marlo. 1986. "Aggregation of U.S. Population Centers Using Climate Parameters Related to Building Energy Use." Joumal of Climate and Applied Meteorology. vol. 25, no. 5. p. 596.

Andrews, John W. and Mark P. Modera. 1991. Energy Savings Potential for Advanced Themal Distribution Technology in Residential and Small Commercial Buildings. Lawrence Berkeley Laboratory. LBL-31042. July.

ARI. 1991. Shipments of Unitary Air Conditioners and Heat Pumps. Air-Conditioning and Refrigeration Institute, Arlington VA. July.

ASHRAE. 1993. ASHRAE Handbook: Fundamentals. Atlanta, GA: American Society of Heating, Refrigeration, and Air-Conditioning Engineers.

Ben-Akiva, Moshe and Steven R. Lerman, 1985. MTT Series in Transportation Studies. Discrete Choice Analysis: Theory and Application to Travel Demand. Cambridge, MA: MIT Press.

Boghosian, Stan. 1991. Description of the Shell Thermal Characteristics of U.S. Residences and Calculation of Shell Retrofit Option Costs. Lawrence Berkeley Laboratory. DRAFT LBL-29417. April.

Boghosian. Stan. 1994. Personal Communication. "Manufactured Home Room Heating Market Shares". Lawrence Berkeley Laboratory, Appliance Standards Group. Sept 8.

Cowing, Thomas G. 1992. "Residential End-Use Energy Demand Modeling and Models". Presented at Eighth Electric Utility Forecasting Symposium in Baltimore, Maryland. Published by Electric Power Research Institute.

Cowing, Thomas G. and Daniel L. McFadden. 1984. Microeconomic Modeling and Policy Anatysis: Snudies in Residential Energy Demand. Academic Press.

Dewerth, Doug. 1991. Memorandum to LBL, 9/25/91. Cleveland, OH: American Gas Association Laboratories.

Dubin, Jeffrey A. 1985. Consumer Durable Choice and the Demand for Electricity. Amsterdam, Holland: North-Holland.

Dubin, Jeffrey A, and Douglas R. Rivers. 1988. SST Users Guide. Pasadena, CA: Dubin, Rivers Associates. 
EIA. 1989. Housing Characteristics 1987, Residential Energy Consumption Survey (RECS). Energy Information Administration, U.S. Dept. of Energy, Washington, DC. DOE/EIA0314(87). May.

EIA. 1990. Energy Consumption and Conservation Potential: Supporting Analysis for the National Energy Strategy. Energy Information Administration. SR/NES/90-02.

EIA. 1992. Housing Characteristics 1990, Residential Energy Consumption Survey (RECS). Energy Information Administration. DOE/EIA-03I4(90). May.

EIA. 1993. 1990 Residential Energy Consumption Survey (RECS): Data Tapes. Energy Information Administration. April.

EPRI. 1982, Residential End-Use Energy Planning System (REEPS). prepared by Carabridge Systematics, Inc. for Electric Power Research Institute. EA-2512. July.

EPRI. 1990. REEPS 2.0 HVAC Model Logic. prepared by Regional Economic Research, Inc. for Electric Power Reseanch Institute. October 11.

EPRI, Electric Power Research Instiaute. 1987. TAG-Technical Assessment Guide: Vol. 2: Electricity End Use. Part 1: Residential Electricity Use--1987. EPRI. EPRI P-4463-SR. vol.2, Part 1. September.

EPRI, Electric Power Research Institute. 1988. Implicit Discount Rates in Residential Consumer Choices: Voll. Investments in Conservation Measures. EPRI. EM-5587, Project 25471. February.

Frost, Karl, Darrinsh Arasteh and Joe Eto. 1993. Savings from Energy Eficient Windows: Current and Future Savings from New Fenestration Technologies in the Residential Market. Lawrence Berkeley Laboratory. LBL-33956. April.

GAMA, 1990. Consumers' Directory of Certified Eficiency Ratings for Residential Heating and Water Heating Equipment. Gas Appliance Manufacturers Association, Inc. October.

GAMA. 1991. Statistical Highlights. annual memo from Gas Appliance Manufacturer's Association, Arlington, VA.

GAMA. 1992. Statistical Release; Gas Warm Air Fumaces by Efficiency Rating. Gas Appliance Manufacturer's Association, Arlington, VA. March 13.

Goett, Andrew. 1990. Review of Equipment HVAC Choice Parameters. Cambridge Systematics, Inc. Memorandum to Regional Economic Research, Inc. July 25.

Hanford, James W., Jonathan G. Koomey, Lisa E. Stewart, Matthew E. Lecar, Francis X. Johnson, Roland J. Hwang and Lynn Price. 1994. Baseline Data for the Residential Sector and Development of a Residential Forecasting Database. Lawrence Berkeley Laboratory. LBL.33717. May.

Hausman, J.A. 1979. "Individual Discount Rates and the Purchase and Utilization of EnergyUsing Durables." Bell Joumal of Economics ard Maragement. vol. 10, no. 3, Spring-p. 33.

Hedrick, R., N. Leslie, M. Witte and W. Bassett. 1991. "Furnace Sizing Criteria for EnergyEfficient Setback Strategies". ASHRAE Transactions Symposium. AN-92-17-1. 
Hirst, E. and 3. Camey. 1978. The ORNL Engineering-Economic Model of Residential Energy Use. Oak Ridge National Laboratory. ORNLCON-24. July.

Huang, Y.J., R. Ritschard and J. Bull. 1987a. Technical Documentation for a Residential Energy Use Database Developed in Support of ASHRAE Special Project 53. Lawnence Berkeley Lab. LBL-24306. November.

Huang, Y.J., R. Ritschard, J. Bull, S. Byme, I Turiel, D. Wilson, C. Hsui and D. Foley. $1987 \mathrm{~b}$. Methodology and Assumptions for Evahuating Heating and Cooling Energy Requirements in New Single-Family Residential Buildings. Technical Support Document for the PEAR Microcomputer Program. Lawrence Berkeley Laboratory. LBL-19128. January.

Hummel, P. and J. S. McMenamin. 1992. "Residential Technology Scenario Analysis: Defining the Role of Efficiency Standards, DSM, and Market Forces". Presented at ACEEE 1992 Summer Stady on Energy Efficiency in Buildings in Asilomar, CA. Pablisheit by American Council for an Energy-Efficient Economy, Washington DC.

Hwang, Roland J., Francis X. Johnson, Richard E. Brown, James W. Hanford and Jonathan G. Koomey. 1994. Residential Appliance Data, Assumptions and Methodology for End-Use Forecasting with EPRI-REEPS 2.I. Lawrence Berkeley Laboratory. LBL-34046. June.

Hydronics Institute, Inc., Berkeley Heights, NJ. 1992. Personal Communication: "Correspondence from John Kausner to Francis X. Johnson". December 11.

Johnson, Francis X. and James W. Hanford. 1992. Memorandum to Regional Economic Research. Lawrence Berkeley Laboratory - Energy Analysis Program. July 17.

Johnson, Francis X., Jonathan Koomey and James E. McMahon, 1992. "Incorporating Technology Choices Into Residential End-Use Forecasting: Evaluation and Comparison of Three Models with Respect to Space Heating." In Proceedings of the 1992 ACEEE Summer Study on Energy Efficiency in Buildings. Asilomar, CA. American Council for an Energy Efficient Economy.

Koomey, Jomathan, Celina Atkinson, Alan Meier, James E. McMahon, Stan Boghosian, Barbara Atkinson, Isaac Turiel, Mart D. Levine, Bruce Nordman and Peter Chan. 1991a. The Potential for Electricity Efficiency Improvements in the U.S. Residential Sector. Lawrence Berkeley Laboratory. LBL-30477. July.

Koomey, Jonathan, James E. McMahon and Cheryl Wodley. 1991b. Improving the Thermal Integrity of New Single-Family Detached Residential Buildings: A Regional Assessment of Capizal Costs and Energy Savings. Lawrence Berkeley Laboratory. LBL-29416. July.

Koomey, Jonathan G., Richard E. Brown and Francis X. Johnson. 1994a. Residential Sector End-use Forecasting with EPRI-REEPS 2.I: Summary Input Assumptions and Results. Lawrence Berkeley Laboratory. LBL-34044. June.

Koomey, Jonathan G., Francis X. Johnson, Jennifer Schuman, Ellen Franconi, Steve Greenberg, Jim D. Lutz, Brent T. Griffith, Dariush Aresteh, Celina Atkinson, Kristin Heinemeier, Y. Joe Huang, Lyan Price, Greg Rosenquist, Francis M. Rubinstein, Steve Selkowitz, Haider Taha and Isaac Turiel. 1994b. Buildings Sector Demand-Side Efficiency Technology Summaries. Lawrence Berkeley Laboratory (Prepared for the Technology Characterization Database of the Intergovernmental Panel on Climate Change). LBL33887. March. 
Lewis, J.E. and A. Clarke. 1990. Replacement Market for Residential Energy Service Equipment (Topical Report, Phase 1A). Gas Research Institute. GRI-89/0204.01. March.

McFadden, D., A. Goett, P. Ruud and K. Train, 1992. Workshop on Qualitative Choice Anabysis. Econometrics Laboratory, Department of Economics, University of California at Berkeley.

McMahon, James E. 1987. "The LBL Residential Energy Model: An Improved Policy Analysis Tool." Energy Systems and Policy. vol. 10, no. 1.

McMenamin, Stuart, Ingrid Rohmund, John Pritchard and Dave Fabiszak. 1992. REEPS 2.I: Residential End-Use Energy Planning System User's Guide. Prepared by Regional Economic Research, Inc, for the Electric Power Research Institute. EPRI Research Project 2863-01.

NAHB, National Research Center. 1989. 1987 Builder Practice Survey Data. National Association of Homebuilders. CR\#5023, PO \#4556710. Manch 1, 1989.

R.S. MEANS Co. 1991a. MEANS Building Construction Cost Data. 1992 Edition Kingston, MA:

R.S. MEANS Co. 1991b. MEANS Mechanical Cost Data. 1992 Edition Kingston, MA:

R.S. MEANS Co. 1991c. MEANS Residential Cost Data. 1992 Edition Kingston, MA:

Ritschard, Ron L., Jim W. Hanford and A. Osman Sezgen. 1992. Topical Report: Single-Family Heating and Cooling Requirements: Assumptions, Methods, and Summary Results. Lawrence Berkeley Laboratory, for the Gas Research Institute. LBL-30377, GRI91/0236. March.

Ritschard, R. L, and Y. J. Huang. 1989. Multifamily Heating and Cooling Requirements: Assumptions, Methods, and Summary Results. Gas Research Institute. GRI-88/0239. November.

Ruderman, Henry, Mark D. Levine and James E. McMahon. 1987. The Behavior of the Market for Energy Efficiency in Residential Appliances Including Heating and Cooling Equipment" The Energy Journal. vol. 8, no. 1. p. 101.

Train, K. 1986. Qualitative Choice Analysis. Cambridge, MA: MTT Press.

US Bureau of Labor Statistics. 1992. Producer Price Index, Detailed Report. US Department of Commerce, Washington DC.

US Bureau of the Census. 1991. Current Construction Reports; Characteristics of New Housing: 1990. US Department of Commerce, Washington DC. C25-9013. June.

US Bureau of the Census. 1992. 1990 Census of Population and Housing: Summary Population and Housing Characteristics. U.S. Department of Commerce, Bureau of the Census. $1990 \mathrm{CPH}-1-1$. March.

US DOE, U.S. Department of Energy. 1989a. State Energy Price and Expenditure Report 1987. Energy Information Administration. DOE/EIA-0376(87). September 1989. 
US DOE, U.S. Department of Energy. 1989b. Technical Support Document: Energy Conservation Standards for Consumer Products: Refrigerators and Fumaces. U.S. Department of Energy, Assistant Secretary, Conservation and Renewable Energy, Building Equipment Division. DOEMEE-0277. November.

US DOE, U.S. Department of Energy 1990. Technical Support Document: Energy Consenation Standards for Constumer Products: Dishwashers, Clothes Washers, and Clothes Dryers. U.S. Department of Energy, Assistant Secretary, Conservation and Renewable Energy, Building Equipment Division. DOE/CE-0299P. December.

US DOE, U.S. Department of Energy. 1993. Technical Support Document: Energy Conservation Standards for Consumer Products: Room Air Conditioners, Water Heaters, Direct Heating Equipment, Mobile Home Fumaces, Kitchen Ranges and Ovens, Pool Heaters, Fluorescent Lamp Ballasts, and Television Sets. U.S. Department of Energy, Assistant Secretary, Energy Efficiency and Renewable Energy, Building Equipment Division. Volume 2: Fluorescent Lamp Ballasts, Television Sets Room Air Conditioners, and Kitchen Ranges and Ovens; DOE/EE-0009. November. 


\section{APPENDIX A: THERMAL SHELL COMPONENT LOADS}

Table A.1 gives the single-family component loads for each component and level and for the North and South regions. We use the single-family component loads to describe all three housing types, with the exception of the residual component loads, which are specified separately for multi-family (residual loads are the remainder of total annual load that cannot be attributed to any of the shell components). By defining a thermal shell package based on a chosen level for each component and a set of building dimensions, the component loads allow simple computation of the total annual heating and cooling requirements. The total annoal loads are simply the weighted linear sum of the component loads. We provide an example of the heating load calculation here for a single-family 2-story house in the north region with heated floor area of 2000 square feet and an unheated basement, as shown in Table A.1 below.

\begin{tabular}{|c|c|c|c|c|c|c|}
\hline Component & Lexel & $\begin{array}{c}\text { Area } \\
\text { Weight }\end{array}$ & $\begin{array}{l}\text { Honting } \\
\text { Compontest } \\
\text { Lond } \\
\text { (xBtu/saft) }\end{array}$ & $\begin{array}{l}\text { Hentin's } \\
\text { Building } \\
\text { Load } \\
\text { (MABn) }\end{array}$ & $\begin{array}{l}\text { Cool'ing } \\
\text { Component } \\
\text { Laad } \\
(\text { Ratu/sg.t) }\end{array}$ & $\begin{array}{l}\text { Canling } \\
\text { Building } \\
\text { Lood } \\
\text { (MMBnt }\end{array}$ \\
\hline $\begin{array}{l}\text { Ceilling } \\
\text { (Insplation) }\end{array}$ & R-19 & 1000 & 7.47 & 7.47 & 1.18 & 1.18 \\
\hline $\begin{array}{l}\text { Walls } \\
\text { (Inspilation) }\end{array}$ & R-11 & 1800 & 13.62 & 27.24 & 1.14 & 2.05 \\
\hline $\begin{array}{l}\text { Unbeated Basemedx } \\
\text { (Floor insulation) }\end{array}$ & R-11 & 1000 & 325 & 3.25 & 1.59 & 1.59 \\
\hline $\begin{array}{l}\text { infilualion } \\
\text { (Air Chranges per How) }\end{array}$ & 0.55 & 2000 & 13.18 & 26.36 & 0.58 & 1.16 \\
\hline $\begin{array}{l}\text { Wudows } \\
\text { (Glasing or Window type) }\end{array}$ & $2-G$ & 220 & 23.23 & 5.11 & 20.88 & 4.59 \\
\hline $\begin{array}{l}\text { Residual Load (MMBtu) } \\
\text { (Single-feitily) }\end{array}$ & none & 1000 & 279 & 2.79 & -1.96 & -1.96 \\
\hline TOTAL (MMBO) & & & & 72.22 & & 8.61 \\
\hline
\end{tabular}

The area is the relevant area or weight for each component. For walls, ceilings and windows, this weight is simply their total area. For infiltration, the relevant area is the cotal heated floor area of 2000 square feet. The residual load is weighted by 1000 to convert to $\mathrm{kBtu}$. The heating and cooling component loads are taken from Table A.2. We divide the calculated building loads by 1000 to convert to MMBm. Thus the total annual heating load for these building dimensions and this thermal shell package is 72,22 MMBru and the total annual cooling load is $8.61 \mathrm{MMBtu}$. 


\begin{tabular}{|c|c|c|c|c|c|}
\hline Component Descriptious & Conponent & $\begin{array}{c}\text { North } \\
\text { Heating }\end{array}$ & o) & $\begin{array}{l}\text { Sonth (C) } \\
\text { Heating }\end{array}$ & $\begin{array}{l}\text { tont) } \\
\text { colings }\end{array}$ \\
\hline $\begin{array}{l}\text { Celfing } \\
\text { (t-Btarsqfit of ceiling) } \\
\text { ceiling insulation } \\
\text { R-walice }\end{array}$ & $\begin{array}{l}R-0 \\
R-7 \\
R-11 \\
R-19 \\
R-22 \\
R-30 \\
R-38 \\
R-49 \\
R-60\end{array}$ & $\begin{array}{r}34,40 \\
13.73 \\
10.43 \\
7.47 \\
6.33 \\
4.80 \\
3.87 \\
3.05 \\
2.52\end{array}$ & $\begin{array}{l}5.42 \\
2.17 \\
1.65 \\
1.18 \\
1.01 \\
0.77 \\
0.63 \\
0.49 \\
0.39\end{array}$ & $\begin{array}{r}14.45 \\
5.69 \\
4.29 \\
3.04 \\
2.56 \\
1.92 \\
1.54 \\
1.23 \\
1.04\end{array}$ & $\begin{array}{l}8.49 \\
3.05 \\
2.18 \\
1.40 \\
1.17 \\
0.86 \\
0.67 \\
0.55 \\
0.47\end{array}$ \\
\hline $\begin{array}{l}\text { Wal: } \\
\text { (kBtu/sqfi of wall) } \\
\text { wall tosulation } \\
\text { R-value }\end{array}$ & $\begin{array}{l}R=0 \\
R-7 \\
R-11 \\
R-13 \\
R-19 \\
R=27 \\
R-34\end{array}$ & $\begin{array}{r}32.85 \\
16.01 \\
13.62 \\
10.72 \\
9.28 \\
6.68 \\
5.08\end{array}$ & $\begin{array}{l}2.61 \\
1.32 \\
1.14 \\
0.88 \\
0.75 \\
0.56 \\
0.43\end{array}$ & $\begin{array}{r}12.25 \\
5.71 \\
4.78 \\
3.64 \\
3.08 \\
2.26 \\
1.75\end{array}$ & $\begin{array}{l}3.90 \\
1.49 \\
1.14 \\
0.78 \\
0.60 \\
0.46 \\
0.37\end{array}$ \\
\hline $\begin{array}{l}\text { Slab } \\
\text { (kBinlin. ft of slab) } \\
\text { perineter R-value } \\
\text { and depth }\end{array}$ & $\begin{array}{l}R-0 \\
R-52 \mathrm{ft} \\
R-54 \mathrm{ft} \\
R-102 \mathrm{ft} \\
R-104 \mathrm{ft}\end{array}$ & $\begin{array}{l}65.02 \\
31.58 \\
22.01 \\
25.38 \\
12.07 \\
\end{array}$ & $\begin{array}{l}-7.72 \\
-6.46 \\
-5.49 \\
-6.10 \\
-4.89 \\
\end{array}$ & $\begin{array}{l}34.26 \\
22.16 \\
19.32 \\
20.17 \\
16.61 \\
\end{array}$ & $\begin{array}{l}-42.54 \\
.42 .18 \\
-41.51 \\
42.06 \\
-41.21\end{array}$ \\
\hline 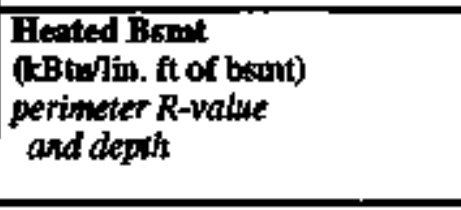 & $\begin{array}{c}R-0 \\
R-54 f t \\
R-58 f t \\
R-104 f t \\
R-108 f t \\
\end{array}$ & $\begin{array}{r}11695 \\
76.71 \\
63.63 \\
66.10 \\
45.92 \\
\end{array}$ & $\begin{array}{l}2.46 \\
0.77 \\
0.83 \\
0.23 \\
0.29\end{array}$ & $\begin{array}{l}52.82 \\
35.23 \\
30.35 \\
31.01 \\
24.81 \\
\end{array}$ & $\begin{array}{l}-21.69 \\
-22.84 \\
-22.60 \\
-23.14 \\
-22.90 \\
\end{array}$ \\
\hline $\begin{array}{l}\text { Un'banted Bsmat } \\
\text { (kBwisqft of fnda) } \\
\text { widerfoor } R \text {-value }\end{array}$ & $\begin{array}{l}\text { R-0 } \\
\text { R-11 flr } \\
\text { R-19 flir } \\
\text { R-30 fir }\end{array}$ & $\begin{array}{r}12.61 \\
3.25 \\
0.60 \\
-1.10\end{array}$ & $\begin{array}{l}0.26 \\
1.59 \\
1.94 \\
2.16\end{array}$ & $\begin{array}{l}5.69 \\
2.58 \\
1.80 \\
1.30\end{array}$ & $\begin{array}{l}-2.34 \\
-1.09 \\
+0.80 \\
+0.61 \\
\end{array}$ \\
\hline $\begin{array}{l}\text { Craw Spaca } \\
\text { (kBtwisqt of fandn) } \\
\text { uadeffoor R+value }\end{array}$ & $\begin{array}{c}\mathrm{R}-0 \\
\text { R-11 fir } \\
\text { R-19 fir } \\
\text { R-30 fir } \\
\text { R-38 frr } \\
\text { R-49 frr }\end{array}$ & $\begin{array}{r}23.22 \\
3.93 \\
0.63 \\
-1.46 \\
-1.93 \\
-3.31\end{array}$ & \begin{tabular}{l|}
2.14 \\
2.71 \\
2.75 \\
2.80 \\
2.82 \\
2.85
\end{tabular} & $\begin{array}{r}10.29 \\
3.10 \\
2.00 \\
1.43 \\
1.30 \\
0.93\end{array}$ & $\begin{array}{l}-0.59 \\
0.01 \\
0.01 \\
0.03 \\
0.09 \\
0.04\end{array}$ \\
\hline $\begin{array}{l}\text { Iniltretion } \\
\text { (kBnisqfit of floor) } \\
\text { Air Changes per Hour (ACH) }\end{array}$ & $\begin{array}{l}0.80 \\
0.70 \\
0.55 \\
0.40 \\
\end{array}$ & $\begin{array}{r}19.50 \\
16.96 \\
13.18 \\
9.45 \\
\end{array}$ & $\begin{array}{l}0.87 \\
0.75 \\
0.58 \\
0.41 \\
\end{array}$ & $\begin{array}{l}.42 \\
4.06 \\
2.40 \\
1.29 \\
\end{array}$ & $\begin{array}{l}3.17 \\
2.68 \\
1.97 \\
1.38 \\
\end{array}$ \\
\hline $\begin{array}{l}\text { Whindows } \\
\text { (t-Btufsgft of window) } \\
\text { ro. of pones/destigs }\end{array}$ & $\begin{array}{c}\text { 1.0-gla } \\
2.0-\mathrm{gla} \\
3.0-\mathrm{gla} \\
\text { 2-gla loE } \\
\text { 2-gia koEAr } \\
\text { Spectral. Ses. } \\
\text { Superwindow } \\
\text { Hear Mirmor } \\
\end{array}$ & $\begin{array}{r}93.68 \\
23.23 \\
0.17 \\
10.44 \\
1.55 \\
21.00 \\
-7.86 \\
14.23 \\
\end{array}$ & $\begin{array}{l}30.13 \\
20.88 \\
18.89 \\
18.39 \\
18.26 \\
13.71 \\
15.52 \\
12.03 \\
\end{array}$ & $\begin{array}{r}16.72 \\
-7.17 \\
-12.36 \\
-9.65 \\
-11.76 \\
-4.95 \\
-12.58 \\
-5.75 \\
\end{array}$ & $\begin{array}{l}51.04 \\
36.46 \\
35.04 \\
33.07 \\
33.75 \\
23.36 \\
29.88 \\
20.92 \\
\end{array}$ \\
\hline Residual Load (Singlefanily) & & 2.79 & -196 & -0.18 & 938 \\
\hline Residunal Load OMullifamily) & & 125 & 2.56 & 3.22 & 10.78 \\
\hline
\end{tabular}




\section{APPENDIX B: HVAC EQUIPMENT VINTAGE BLOCKS}

Tables B.1 through B.12 provide vintage block data for each type of heating and cooling equipment configured in our model. The vintage blocks describe the efficiency profile over time of existing equipment installed in homes. As equipment is retired according to the linear retirement/replacement function in REEPS, the vintage blocks allow for the appropriate efficiencies to be retired and the equipment stock to be adjusted ascondingly. 


\begin{tabular}{|c|c|c|c|}
\hline $\begin{array}{l}\text { Vintage } \\
\text { Bock } \\
\text { Buns: }\end{array}$ & $\begin{array}{c}\text { Averay } \\
\text { Ehildency } \\
\text { AFUE }\end{array}$ & $\begin{array}{l}\text { North Region } \\
\text { Share of igs } \\
\text { stockb } \\
\text { (percent) }\end{array}$ & $\begin{array}{l}\text { South Regle: } \\
\text { Starw of 1990 } \\
\text { Stockb } \\
\text { (percent) }\end{array}$ \\
\hline pre-1971 & 659 & 27.2 & 24.2 \\
\hline 1971,1980 & 713 & 28.6 & 35.0 \\
\hline 1981.1985 & 74.2 & 18.0 & 22.9 \\
\hline 1986,1988 & 75.1 & 17.4 & 10.6 \\
\hline 1989,1990 & 76.4 & 8.7 & 7.3 \\
\hline
\end{tabular}

Table B.2 Central Ofl Formace Stock Dota

\begin{tabular}{|c|c|c|c|}
\hline $\begin{array}{l}\text { Vintrige } \\
\text { Block } \\
\text { Ranise }\end{array}$ & $\begin{array}{c}\begin{array}{c}\text { Average } \\
\text { Efiiciency }\end{array} \\
\text { AFUE }\end{array}$ & $\begin{array}{c}\text { North Retion } \\
\text { Share of } 1990 \\
\text { Stockb } \\
\text { (percent) }\end{array}$ & $\begin{array}{c}\text { South Reglon } \\
\text { Shore of 19\% } \\
\text { Stockb } \\
\text { (percent) }\end{array}$ \\
\hline pet-1971 & 66.4 & 33.5 & 375 \\
\hline 1971,1980 & 73.8 & 23.0 & 23.8 \\
\hline 1981, 1985 & 76.3 & 159 & 18.7 \\
\hline 1986,1988 & 77.2 & 18.0 & 14.9 \\
\hline 1989,1990 & 78.6 & 9.7 & 5.1 \\
\hline \multicolumn{4}{|c|}{$\begin{array}{l}\text { Sorce: a Averaige Stipment-Weighted Ënergy Factors (SWEFs), } \\
\text { (GAMA 1991) } \\
\text { b. } 1990 \text { RECS (EIA 1993). }\end{array}$} \\
\hline
\end{tabular}

Tablo B.3 LPG Furnace Stock Data

\begin{tabular}{|c|c|c|c|}
\hline $\begin{array}{l}\text { Vintige } \\
\text { Dlock } \\
\text { Romoge }\end{array}$ & $\begin{array}{c}\text { Average } \\
\text { Etingiency } \\
\text { AFUE }\end{array}$ & $\begin{array}{c}\text { North Region } \\
\text { Share of } 19 \text { s } \\
\text { stoukb } \\
\text { (percent) }\end{array}$ & $\begin{array}{c}\text { South Region } \\
\text { Share of 1990 } \\
\text { Stackb } \\
\text { (peretat) }\end{array}$ \\
\hline pre-1971 & 65.9 & 15.7 & 9.0 \\
\hline 1971,1980 & 71.3 & 24.3 & 29.8 \\
\hline 1981,1985 & 74.2 & 17.6 & 27.5 \\
\hline 1986, 1988 & 75.1 & 21.5 & 16.2 \\
\hline 1989,1990 & 76.4 & 21.0 & 17.5 \\
\hline \multicolumn{4}{|c|}{$\begin{array}{l}\text { Source: a. Average Shipment-Weightod Energy Factors (SWEFs), } \\
\text { (GAMA 1991) } \\
\text { b. 1990 RECS (EIA 1993). }\end{array}$} \\
\hline
\end{tabular}




\begin{tabular}{|c|c|c|c|}
\hline \multicolumn{4}{|c|}{ Table B.4 Gas Boilers Stodk Data } \\
\hline $\begin{array}{l}\text { Pintage } \\
\text { Bhodk } \\
\text { Renge }\end{array}$ & $\begin{array}{c}\text { Average } \\
\text { Efiociancy } \\
\text { AFUE }\end{array}$ & $\begin{array}{c}\text { North Region } \\
\text { Share of igss } \\
\text { Stockb } \\
\text { (percent) }\end{array}$ & $\begin{array}{c}\text { Sonth Reglon } \\
\text { Share of } 1990 \\
\text { Stackl } \\
\text { (mercent) }\end{array}$ \\
\hline pre-1971 & 70.1 & 409 & 41.8 \\
\hline 1971,1980 & 72.3 & 26.6 & 22.5 \\
\hline 1981,1985 & 77.4 & 132 & 89 \\
\hline 1986,1988 & 78.2 & 8.5 & 16.7 \\
\hline 1989,1990 & 79.7 & 109 & 10.1 \\
\hline
\end{tabular}

\begin{tabular}{|c|c|c|c|}
\hline \multicolumn{4}{|c|}{ Tolle B.S Oll Boilers Stack Data } \\
\hline $\begin{array}{l}\text { Vintoge } \\
\text { Block } \\
\text { Range }\end{array}$ & $\begin{array}{c}\text { Average } \\
\text { Eniciency } 2 \\
\text { AFUE }\end{array}$ & $\begin{array}{l}\text { North Region } \\
\text { Share of loso } \\
\text { Stockb } \\
\text { (percent) }\end{array}$ & $\begin{array}{c}\text { South Region } \\
\text { Share of 19so } \\
\text { Stockb } \\
\text { (percent) }\end{array}$ \\
\hline pre-1971 & 71.2 & 41.8 & 692 \\
\hline 1971,1980 & 75.2 & 20.7 & 30.8 \\
\hline 1981,1985 & 77.4 & 152 & 0.0 \\
\hline 1986, 1988 & 81.6 & 13.0 & 0.0 \\
\hline 1989,1990 & 83.1 & 9.3 & 0.0 \\
\hline \multicolumn{4}{|c|}{$\begin{array}{l}\text { Source: a. Engthering estimates based on available modeks, } \\
\text { (Hydronics Instionte 1992). } \\
\text { b. 1990 RECS (ELA 1993). }\end{array}$} \\
\hline \multicolumn{4}{|c|}{ Table B.6 Ges Room Stock Data } \\
\hline $\begin{array}{l}\text { Vlntape } \\
\text { Blodx } \\
\text { Romige }\end{array}$ & $\begin{array}{c}\text { Averese } \\
\text { EAficteency } \\
\text { AFUE }\end{array}$ & $\begin{array}{c}\text { North Region } \\
\text { shrie of 19y } \\
\text { Stockb } \\
\text { (percent) }\end{array}$ & $\begin{array}{c}\text { South Repion } \\
\text { Shive of tose } \\
\text { Stock } \\
\text { (oercent) }\end{array}$ \\
\hline pre-1971 & 56.4 & 36.4 & 48.3 \\
\hline 1971,1980 & 59.5 & 35.9 & 22.6 \\
\hline 1981,1985 & 63.1 & 11.5 & 15.6 \\
\hline 1986, 1988 & 64.2 & 7.1 & 8.3 \\
\hline 1989,1990 & 65.6 & 9.2 & 5.2 \\
\hline \multicolumn{4}{|c|}{$\begin{array}{l}\text { Sowwce: a. Engineering estimates based on available wodels, } \\
\text { (GAMA 1991) } \\
\text { b. 1990 RECS (EIA 1993). }\end{array}$} \\
\hline
\end{tabular}




\begin{tabular}{|c|c|c|c|}
\hline \multicolumn{4}{|c|}{ Table B.7 Electric Central Furnece Stock Doto } \\
\hline $\begin{array}{l}\text { Virtuge } \\
\text { Blocts } \\
\text { Ringe }\end{array}$ & $\begin{array}{c}\text { Avernge } \\
\text { Emolency } \\
\text { N/A }\end{array}$ & $\begin{array}{c}\text { North Region } \\
\text { Share of 1999 } \\
\text { Stoct: } \\
\text { (percent) }\end{array}$ & $\begin{array}{c}\text { Sowth Region } \\
\text { Shro of 19s } \\
\text { stock } \\
\text { (percent) }\end{array}$ \\
\hline $\begin{array}{c}p 10-1971 \\
1971,1980 \\
1981,1985 \\
1986,1988 \\
1989,1990\end{array}$ & & $\begin{array}{c}5.9 \\
65.4 \\
18.3 \\
9.7 \\
0.6\end{array}$ & \begin{tabular}{r|}
9.9 \\
48.3 \\
26.0 \\
103 \\
5.4
\end{tabular} \\
\hline \multicolumn{4}{|c|}{ Source: a. 1990 RECS (EIA 1993). } \\
\hline \multicolumn{4}{|c|}{ Table B.8 Electric Room Stock Deta } \\
\hline $\begin{array}{l}\text { Vintoge } \\
\text { Btock } \\
\text { Roragra }\end{array}$ & $\begin{array}{c}\text { Averiqe } \\
\text { Eriliency } \\
\text { N/A }\end{array}$ & $\begin{array}{l}\text { North Reglon } \\
\text { Share of 19s } \\
\text { Stoctl } \\
\text { (percent) }\end{array}$ & $\begin{array}{l}\text { South Region } \\
\text { Share of 19so } \\
\text { Stocll } \\
\text { (percent) }\end{array}$ \\
\hline $\begin{array}{c}p 0-1971 \\
1971,1980 \\
1981,1985 \\
1986,1988 \\
1989,1990\end{array}$ & & $\begin{array}{r}30.2 \\
39.1 \\
18.3 \\
5.4 \\
7.0\end{array}$ & $\begin{array}{c}25.8 \\
23.6 \\
19.9 \\
20.8 \\
99\end{array}$ \\
\hline \multicolumn{4}{|c|}{ Sormce: a. 2990 RECS (ELA 1993). } \\
\hline $\begin{array}{l}\text { Venonge } \\
\text { Block } \\
\text { Ronge }\end{array}$ & $\begin{array}{c}\text { Averase } \\
\text { Enitelency } \\
\text { AFUE }\end{array}$ & $\begin{array}{c}\text { North Requigh } \\
\text { Share of } 1990 \\
\text { Stock b } \\
\text { (aercent) }\end{array}$ & $\begin{array}{c}\text { Sowth Refiton } \\
\text { Share of jagh } \\
\text { Stockb } \\
\text { (percent) }\end{array}$ \\
\hline pre-1971 & 70.0 & 109 & 7.6 \\
\hline 1971,1980 & 70.0 & 28.0 & 26.0 \\
\hline 1981,1985 & 70.0 & 32.3 & 27.3 \\
\hline 1986,1988 & 70.0 & 21.7 & 29.5 \\
\hline 1989,1990 & 70.0 & 7.1 & 9.6 \\
\hline
\end{tabular}




\begin{tabular}{|c|c|c|c|}
\hline \multicolumn{4}{|c|}{ Table B.10 Central Air Conditioner Stock Data } \\
\hline $\begin{array}{l}\text { Vintinge } \\
\text { Block } \\
\text { Renge }\end{array}$ & $\begin{array}{c}\text { Averaso } \\
\text { Euiditncy } \\
\text { SEER }\end{array}$ & $\begin{array}{l}\text { North Region } \\
\text { Shere of ison } \\
\text { Stockb } \\
\text { (pereet) }\end{array}$ & $\begin{array}{l}\text { Sowth Region } \\
\text { Slwar of igso } \\
\text { Stoekb } \\
\text { (percent) }\end{array}$ \\
\hline pre-1971 & 6.74 & 10.4 & 10.0 \\
\hline 1971,1980 & 7.33 & 35.2 & 33.2 \\
\hline 1981,1985 & 8.42 & 18.9 & 28.5 \\
\hline 1986,1988 & 9.04 & 22.5 & 56.4 \\
\hline 1989,1990 & 9.21 & 13,0 & 11.9 \\
\hline \multicolumn{4}{|c|}{$\begin{array}{l}\text { Source: a. Average Shipenent-Weighted Energy Faciors (SWEFs), } \\
\text { (ARI 1991). } \\
\text { b. } 1990 \text { RECS (EIA 1993). }\end{array}$} \\
\hline
\end{tabular}

Table B.11 Room Air Conditioner Stock Dato

\begin{tabular}{|c|c|c|c|}
\hline $\begin{array}{l}\text { Vintoge } \\
\text { Block } \\
\text { Renge }\end{array}$ & $\begin{array}{c}\text { Average } \\
\text { Efinciency } \\
\text { EFR }\end{array}$ & $\begin{array}{l}\text { Noth Region } \\
\text { Share of } 1950 \\
\text { stocld } \\
\text { (percent) }\end{array}$ & $\begin{array}{c}\text { South Region } \\
\text { Share of } 1990 \\
\text { Staclb } \\
\text { (percete) }\end{array}$ \\
\hline pre-1971 & 5.82 & 7.0 & 6.7 \\
\hline 1971,1980 & 6.51 & 26.6 & 27.1 \\
\hline 1981,1985 & 7.43 & 28.0 & 34.3 \\
\hline 1986,1988 & 8.52 & 25.0 & 20.7 \\
\hline 1989,1990 & 8.64 & 13,3 & 11.2 \\
\hline
\end{tabular}

Sounce: a Average Shipnent-Weighted Energy Factors (SWEFs), (AHAM 1991).

b. 1990 RECS (EIA 1993), based on the "most used" roon afr conditioner in the household.

\begin{tabular}{|c|c|c|c|}
\hline \multicolumn{4}{|c|}{ Table B.t2 Heat Pelapp Stodk Dota } \\
\hline 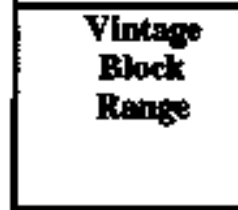 & $\begin{array}{c}\text { Average } \\
\text { Efilciency } \\
\text { SEFR }\end{array}$ & $\begin{array}{c}\text { North Regioa } \\
\text { Sture of j990 } \\
\text { Stockb } \\
\text { (percent) }\end{array}$ & $\begin{array}{c}\text { South Region } \\
\text { Shore of iege } \\
\text { Stochb } \\
\text { (peroent) }\end{array}$ \\
\hline jte-1971 & 7.11 & 0.0 & 2.9 \\
\hline 1971,1980 & 7.96 & 32.5 & 203 \\
\hline 1981,1985 & 8.85 & 36.8 & 40.0 \\
\hline 1986,1988 & 9.12 & 21.4 & 26.8 \\
\hline 1989,1990 & 9.37 & 9.2 & 9.9 \\
\hline
\end{tabular}




\section{APPENDIX C: SIZE AND EFFICIENCY DISTRIBUTIONS}

Figures $\mathrm{C} .1$ a-c through $\mathrm{C} .4 \mathrm{a}-\mathrm{c}$ show the distribution by size (capacity) and efficiency for the most recent year available for four types of heating and cooling equipment. These data represent the minimum level of disaggregation necessary to develop decision models and parameters. The data represent shipments reported by the relevant trade organizations for the various products (ARI 1991, GAMA 1992). Some trade organizations provide the data to a sufficient level of detail for our analysis (ARI 1991). In those cases where the trade organizations provide only a few efficiency categories, we have broken these out into additional categories by tabulating the number of madels within a given size category as listed in the model directories (GAMA 1990). Note that this approximation may not exactly characterize the distribution of equipment sales, since the number of models is only loosely comelated with sales. 

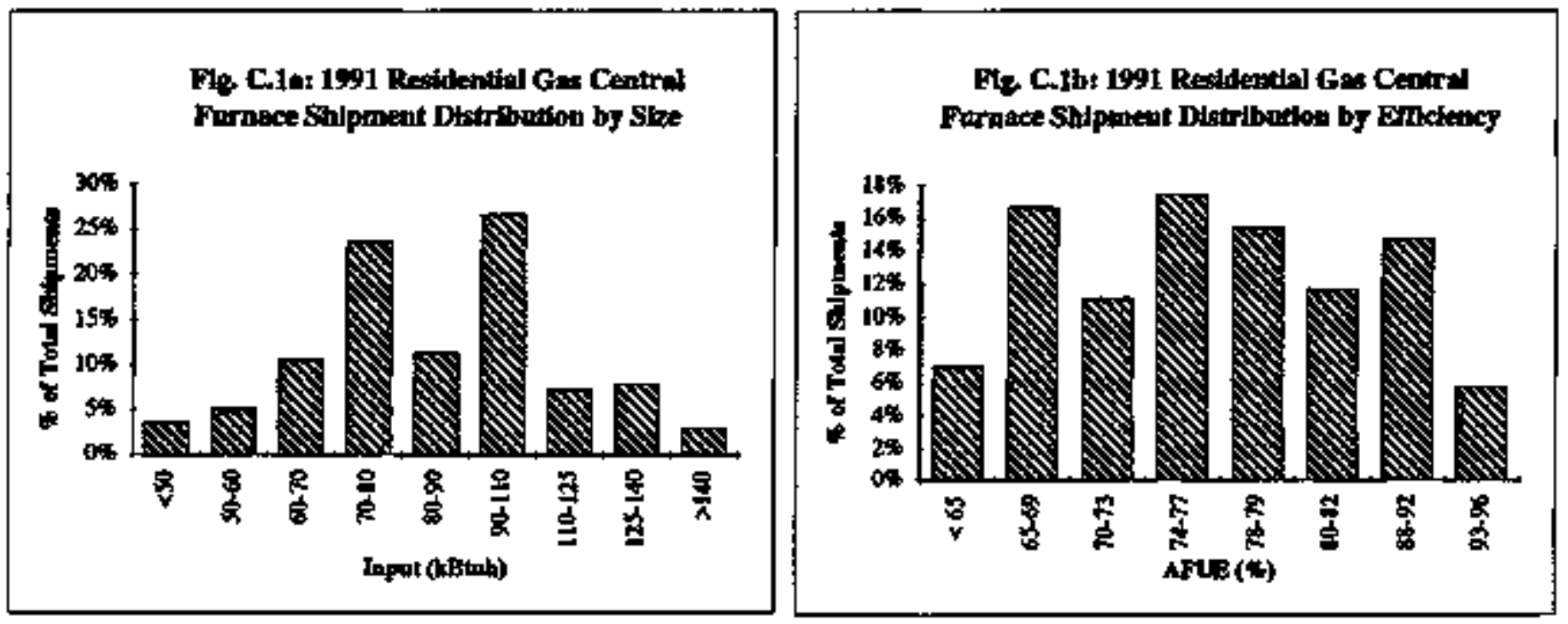

Figure Cic: 1901 Residential Gas Central Furnace Shipments by Size and Efitiency

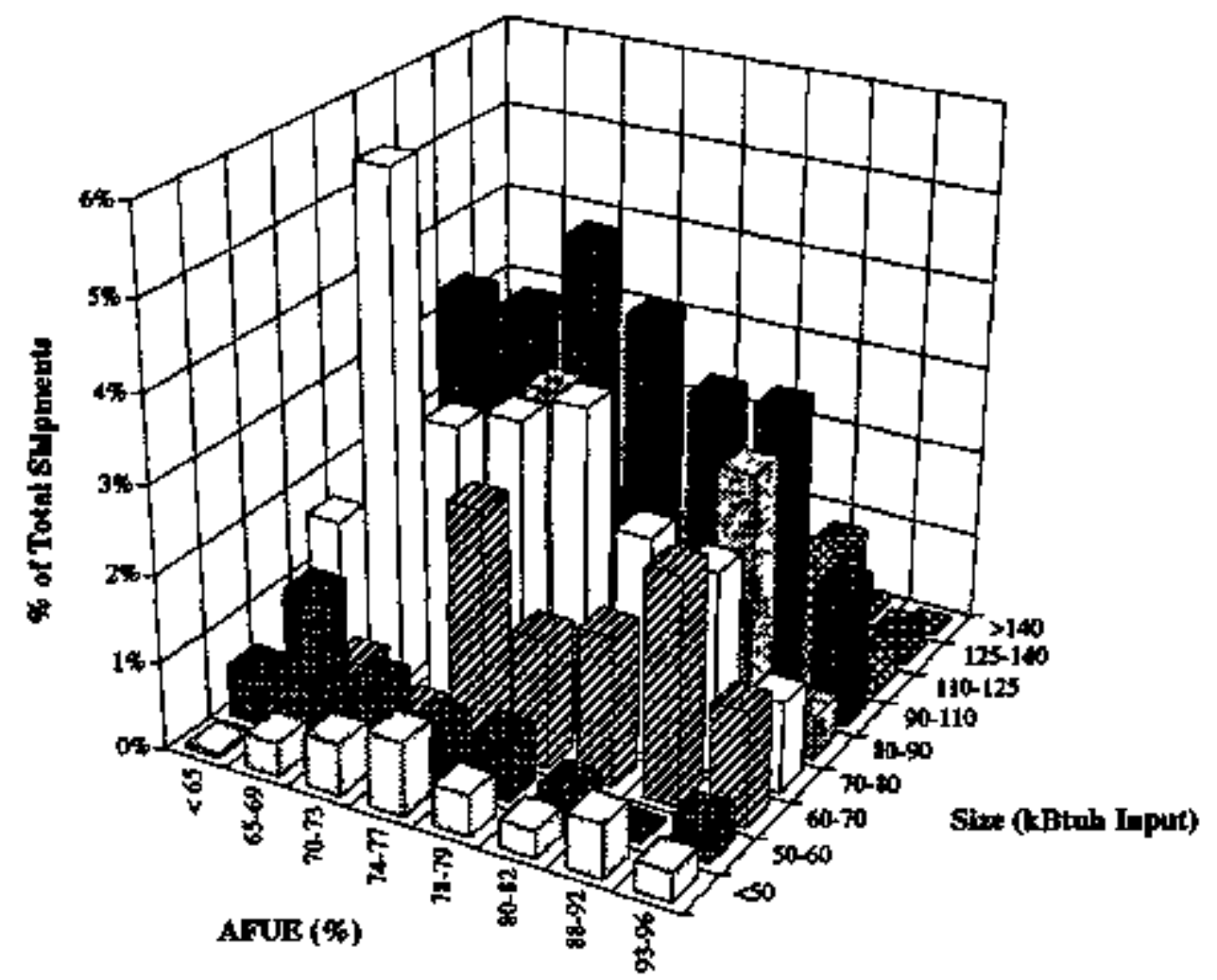

(1) Sotires: GAMA (199La), GAMA (1992).

(2) Some gize categories have been corbinted at the two ends of the distribution.

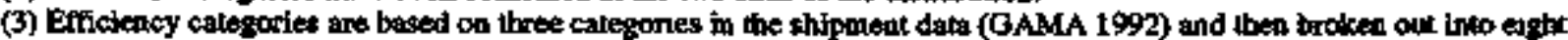
calegories based on the number of models within each of the the categorits as given in the model diroctory (GAMA 1991a). 

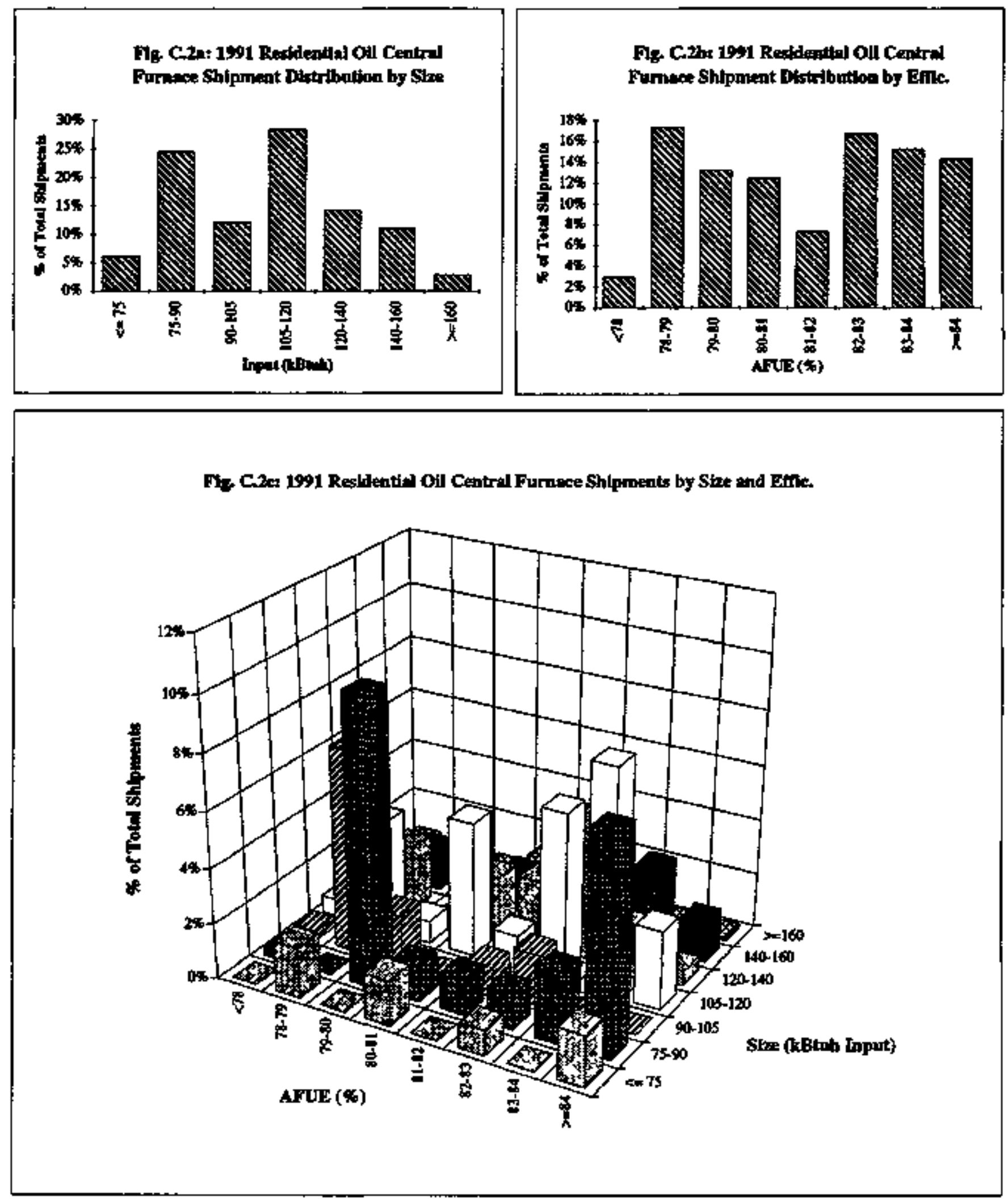

(1) Sotices: GAMA (1991a), OAMA (1992)

(2) Sone gize categories have been combined at the two eands of the distribution.

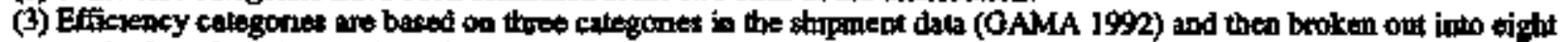

categories baced on the murnber of models whin each of the thres categones as grven mo the model directory (GAMA. 1991 a). 

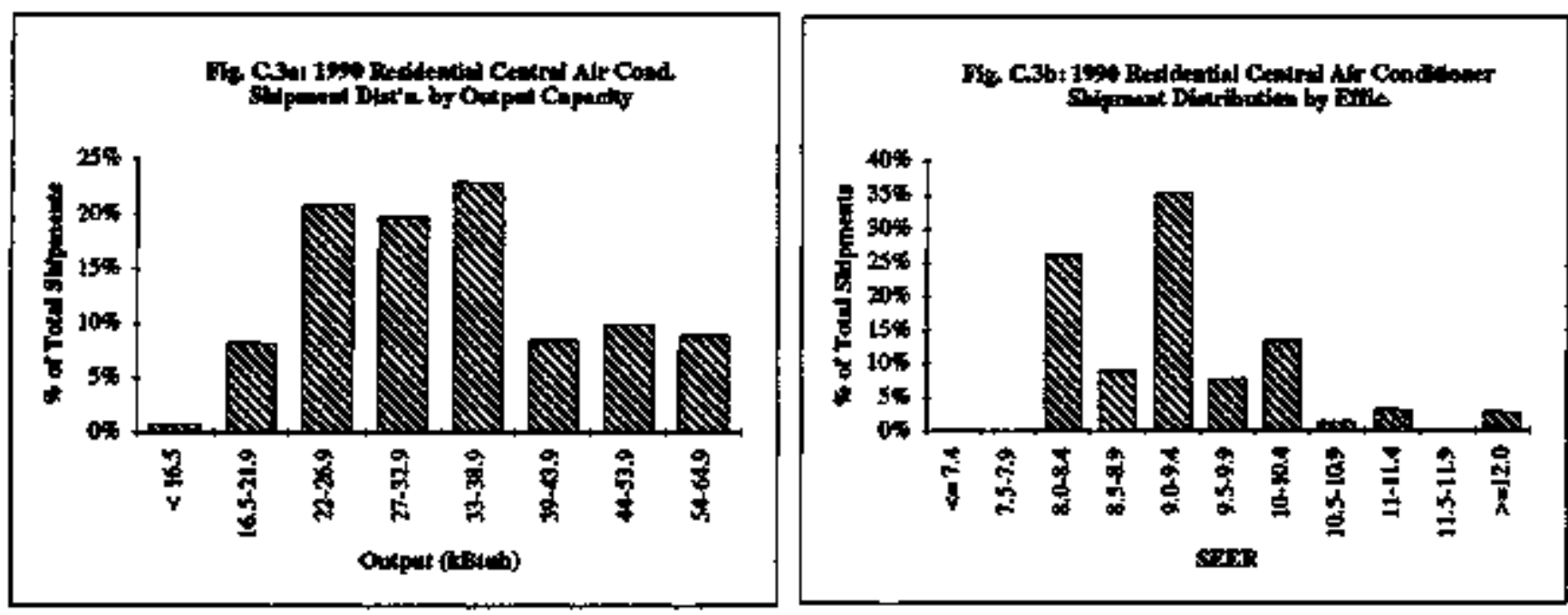

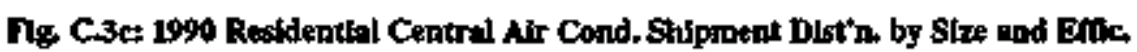

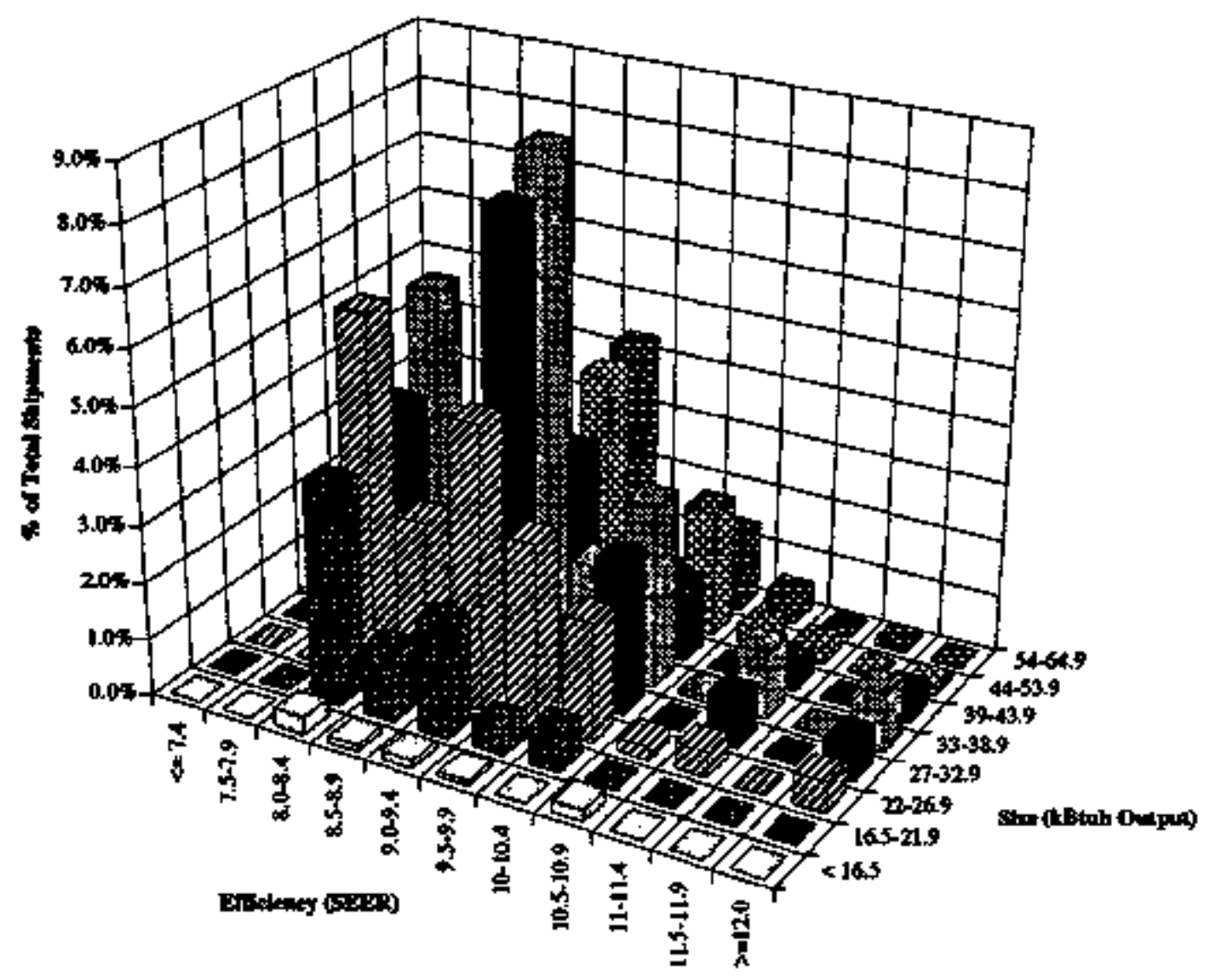

(1) Sorice: ARI (1991).

(2) Resdeatid Centril Air Conditionens ane defined as those $<65$ kBtuh Output.

(3) The distributions shown include only split-systems. 

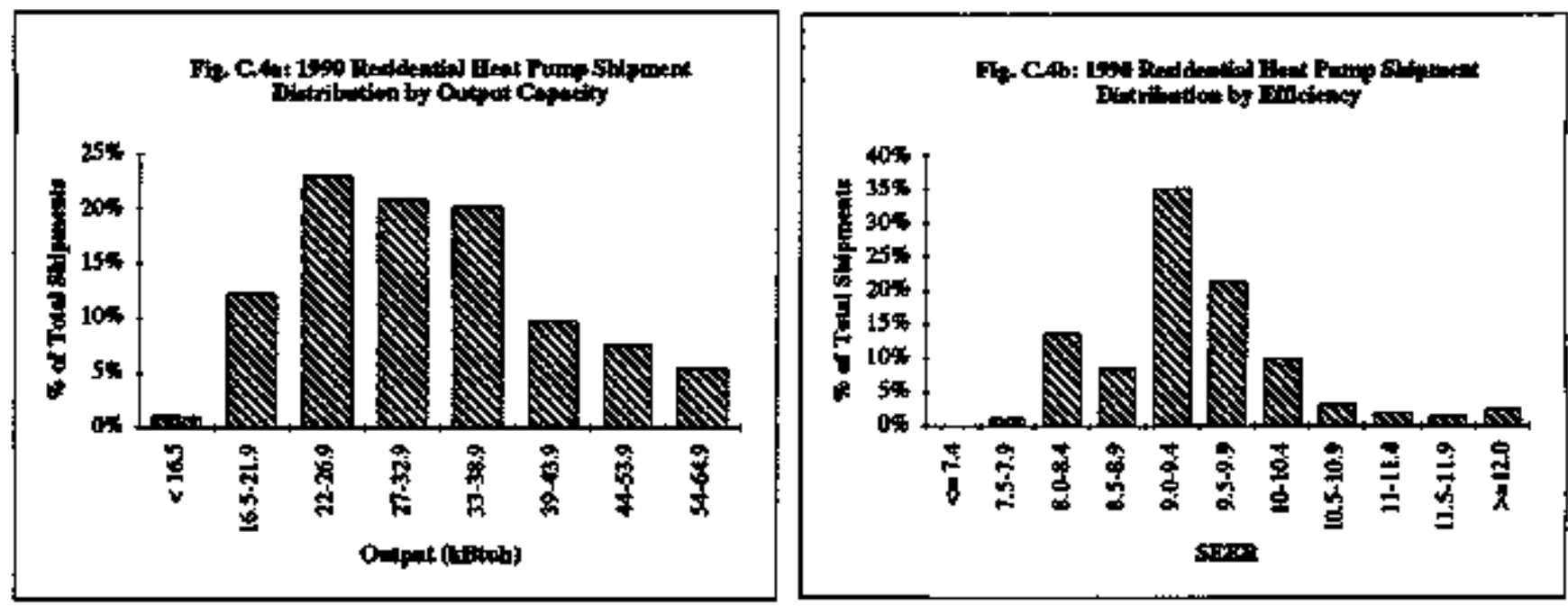

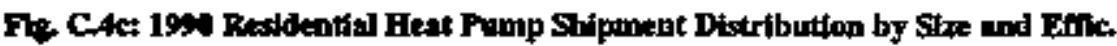

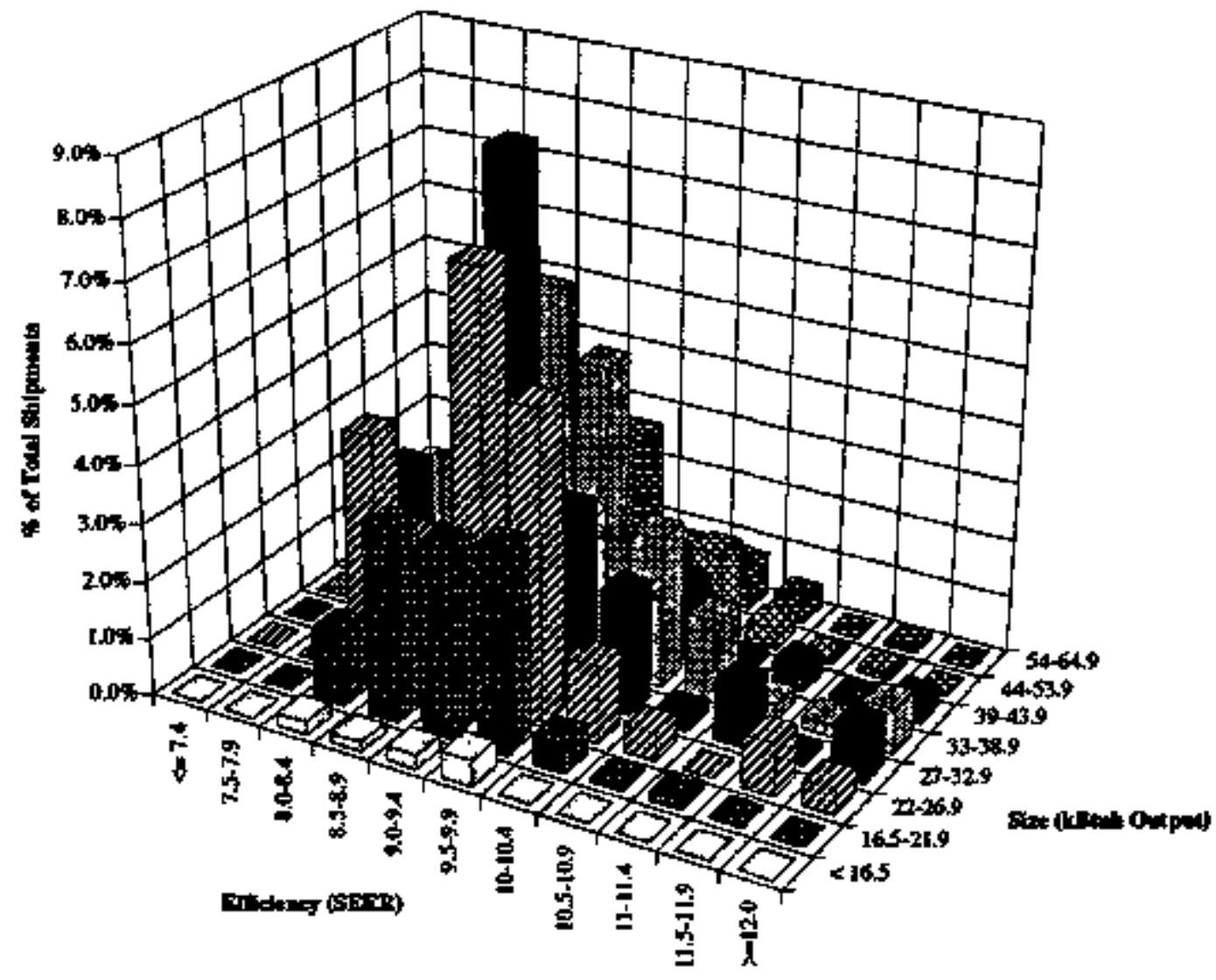

(1) Sourcet ARI (1991).

(2) Ressidential Heat Pumps are defined as those < 65 kBtob Output.

(3) The distribetions shown inchude only split-syserems. 


\section{APPENDIX D: PEAK LOAD CALCULATIONS}

Tables D.1 through D.4 show the data and regression lines for the calculation of peak loads based on annual loads. This calculation is necessary because the annual loads are available within the REEPS forecast as endogenous variables whereas the peak loads are not. We assumed that the peak heating and cooling loads could be expressed as a linear function of the respective annual loads in each region. There are separate functions for single-family homes and multifamily homes, as shown in the eight graphs. The resulting regression relations are used to estimate installed equipment capacity as a function of peak load for each heating/cooling system. The regression parameters are presented in Table 5.1 in the main text 
Table D.1-N: SF North Heating Peak vs. Anmual Load

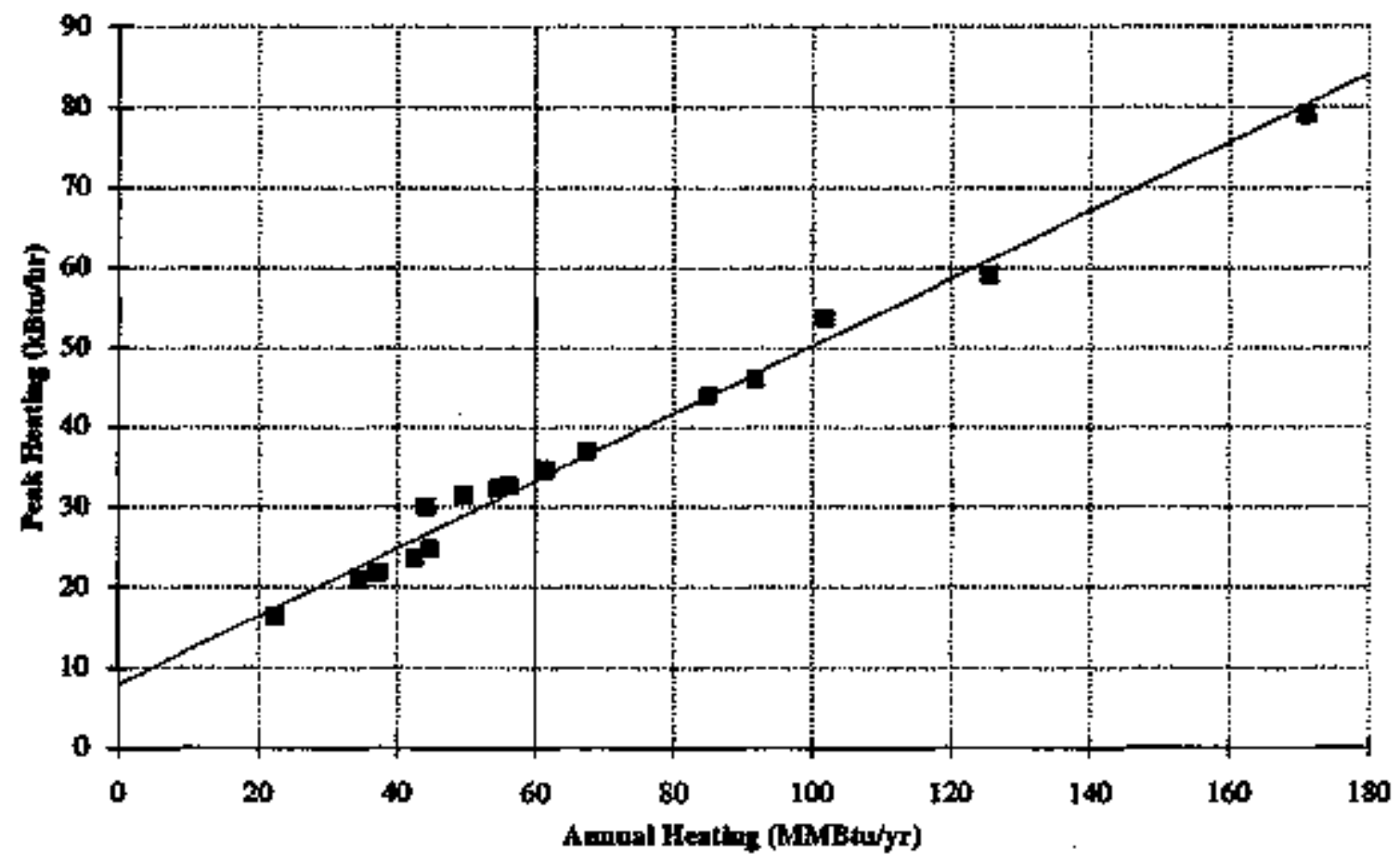

Figure D.2-N: SF North Cooling Peak vs Annusl Load

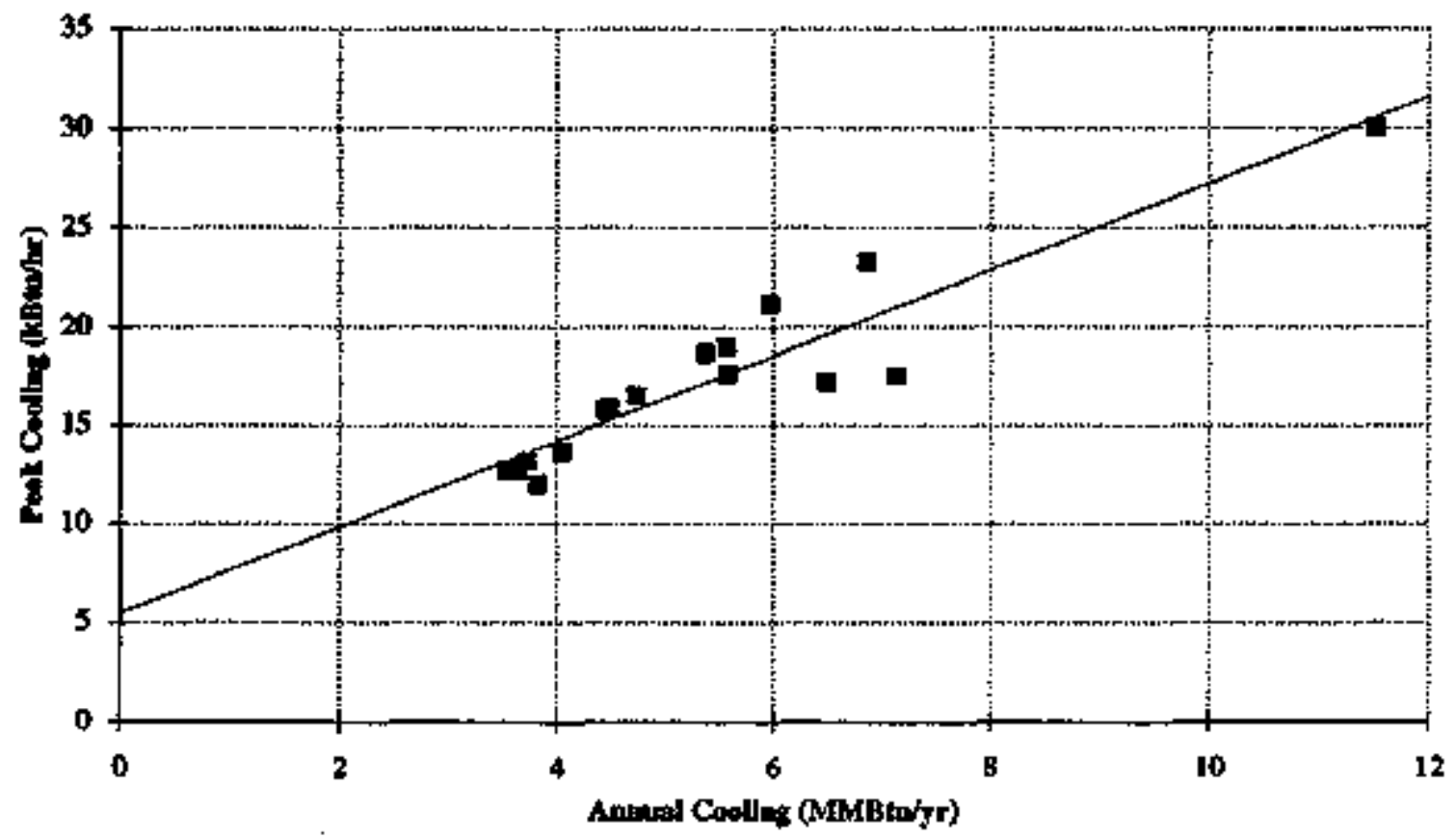

(1) Source- Based on DOE-2 simulation nuns for single-family prodotypes of differing themal integrity. 
Figure D.1-S: SF Sonth Heating Peaks vs. Anuugl Loads

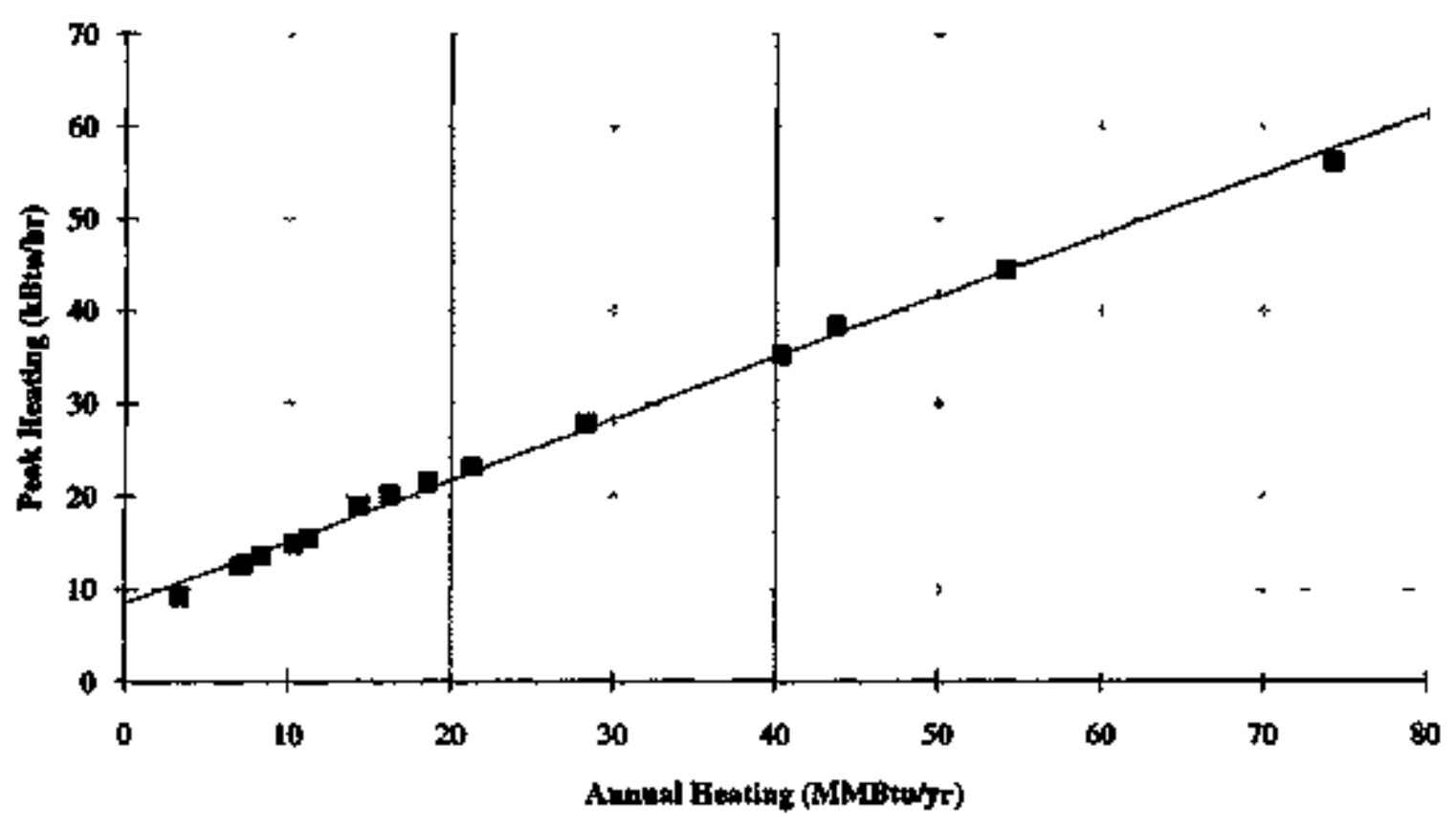

Figure D.2-S: SF South Cooling Peaks vs. Anmual Laads

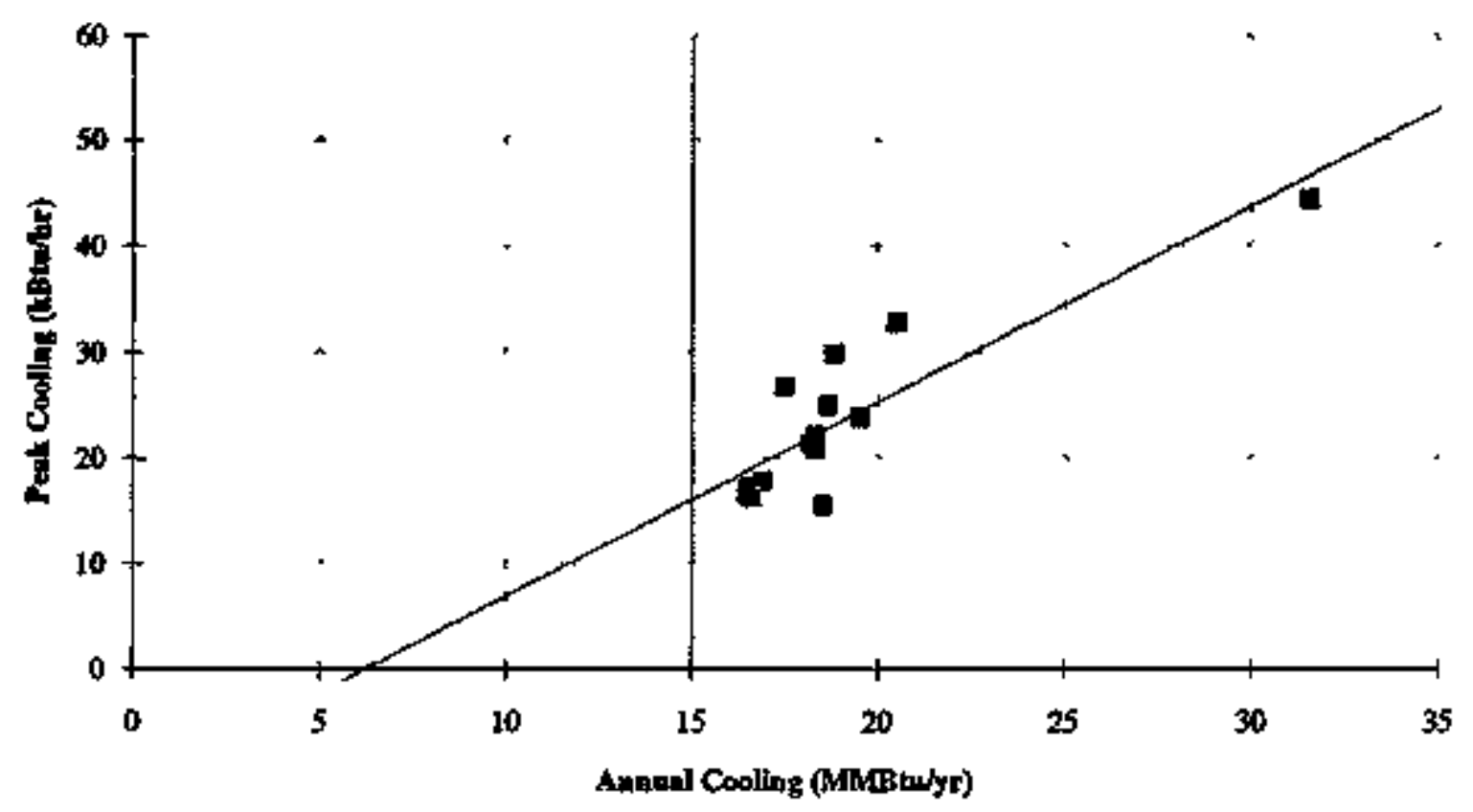

(1) Soance: Based on DOE-2 simalation nons foe protocypes of differing thermal integrity. 


\section{Figure D-3-N: MF North Heating Peak vs. Amuial Logd}

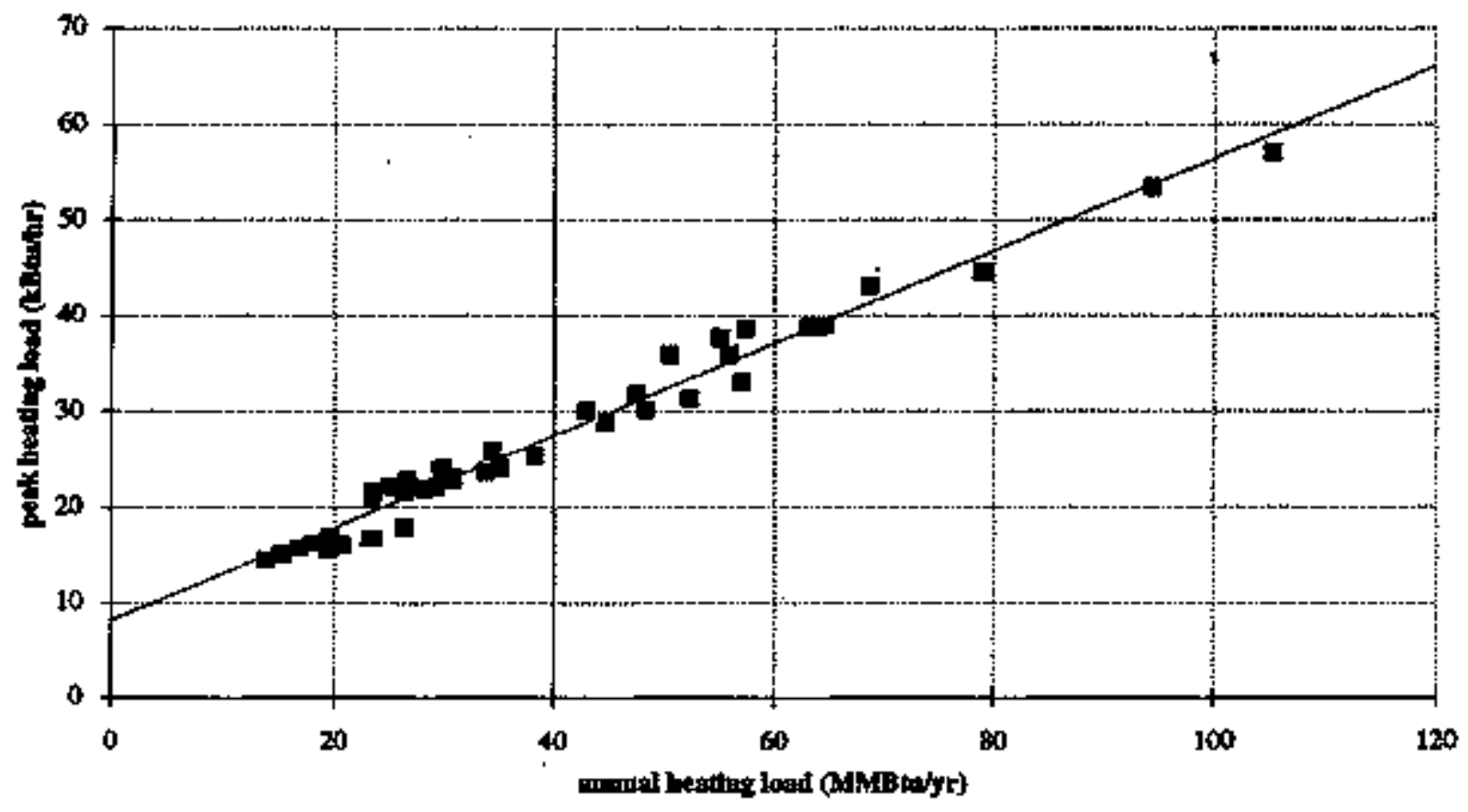

Figure D.4-N: MF North Cooling Peak vs. Annual Load

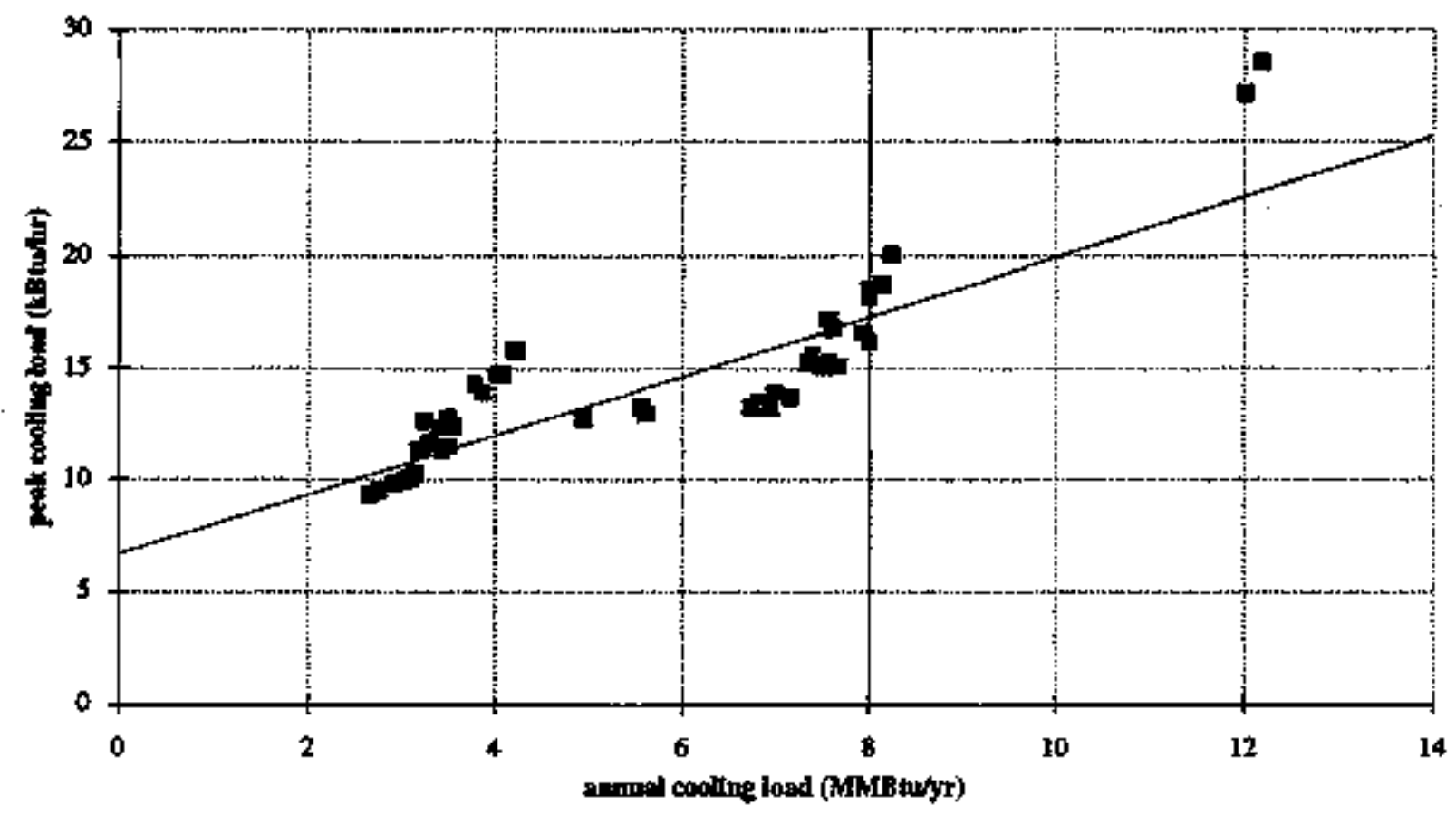

(1) Source: Based on DOE-2 simnlation nuns for mallifamily prototypes of differtng thermal integrity. 
Flgure D.3-S: MF Sonth Heating Peak vs. Amnall Load

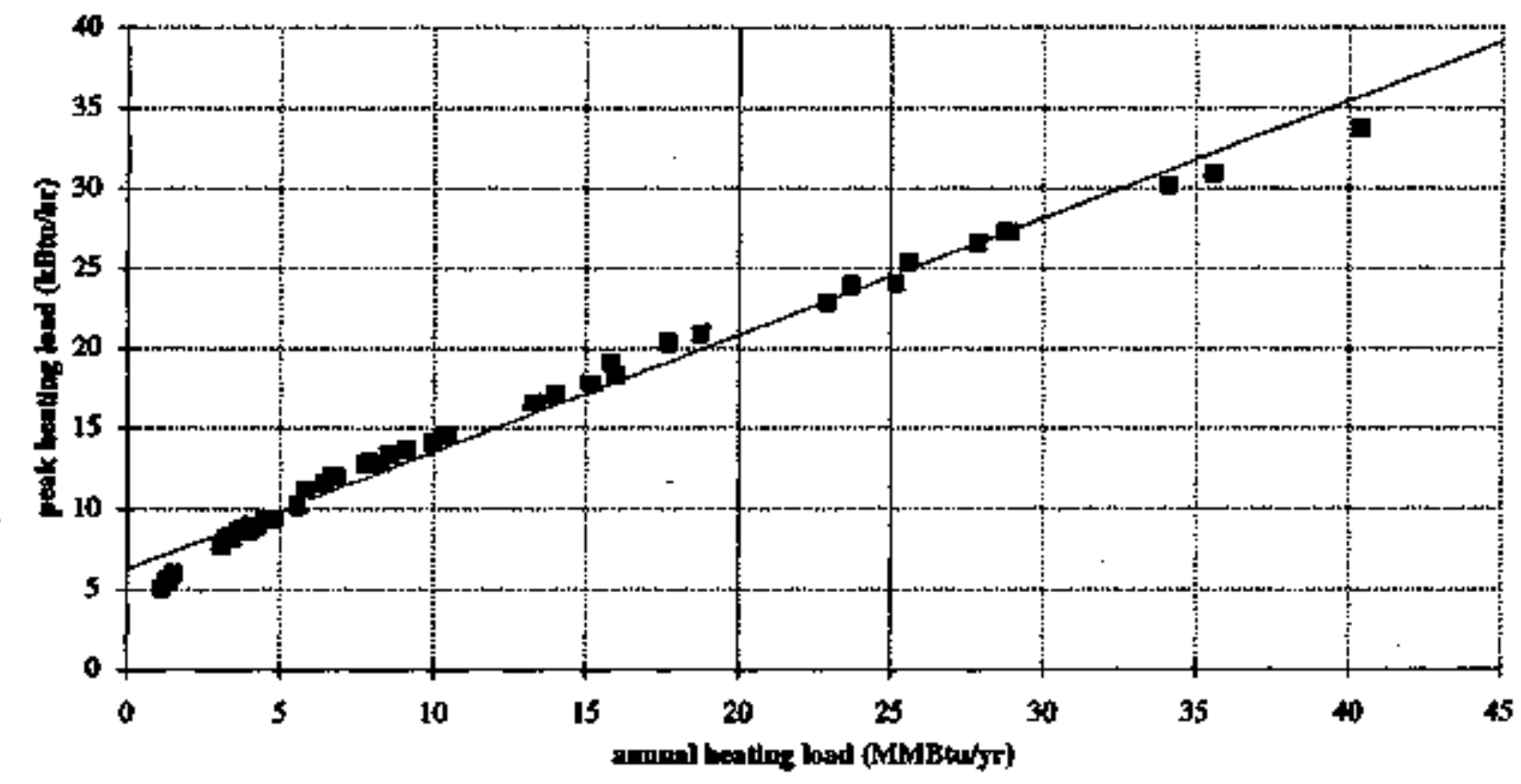

Figure D.4-S: MF South Cooling Peak vs. Annual Load

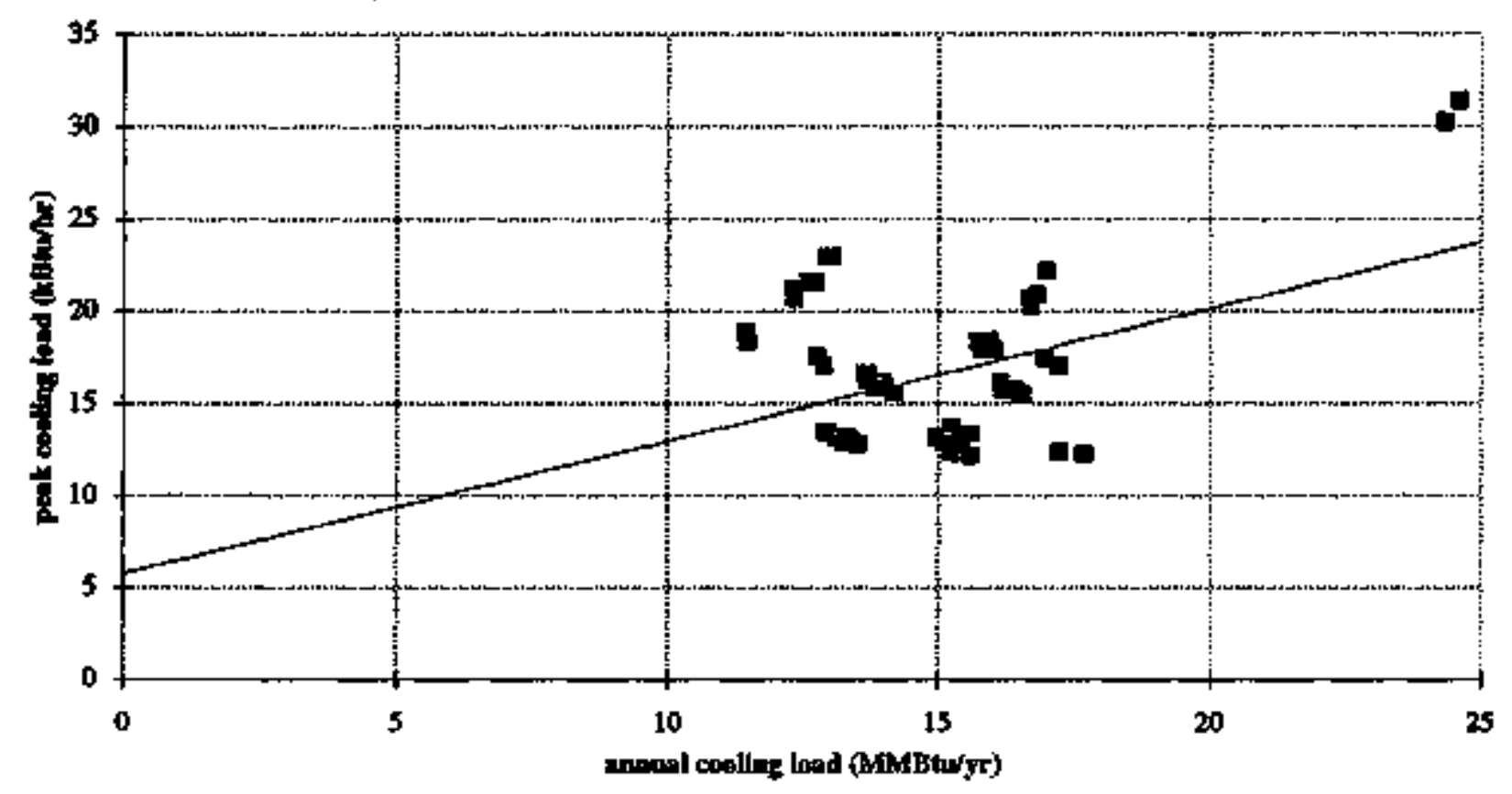

(1) Source: Bayed on DOE-2 simulation runs fox multi-family proctypes of differing thermal integrity. 


\section{APPENDIX E: EQUIPMENT PRICE DATA AND PARAMETER ESTIMATION}

There were a number of different steps in the estimation of the heating and cooling equipment price models. As discussed in Section 5.3, REEPS estimates the purchase price of equipment as a function of size and efficiency. The purchase price includes both the price of the materials and the installation price. We calculated separately the installation price and material price to an HVAC subcontractor for various sizes of equipment (R.S. MEANS Co. 1991b) and deflated these prices from 1992 to 1990 dollars using a Purchaser Price Index for Appliances (US Bureav of Labor Statistics 1992). We added sales tax to the material price of the equipment, using the average value for the U.S. (R.S. MEANS Co. 1991c) of 4.6\%. We added a subcontractor markup of 15-25\% to the material and installation prices and then added a contractor markup of $10-15 \%$ to the total installed price.

Next we assessed the relationship between price and efficiency for each equipment type. We determined the manufacturer price for models of a given size, but of varying efficiency (ADM 1987) and inflated these values to 1990 dollars again using the PPI for Appliances. We calibrated the values based on size to the values based on efficiency by assuming that the MEANS data is based on the average efficiency of equipment. This allowed us to develop an estimate of the "implicit" manufacturer markup in order to have a single function for each equipment type. This function was obtained by fitting a linear regression line to the price-size data and fitting a non-linear regression to the manufacturer price data with the implicit manufacturer markup. This process yielded parameters $b, m$, and $\varepsilon$ in Equation 5.4. The data points and regression line for the linear regressions are shown in Figures E.1a to E.7a while the data points and regression lines for the non-linear regressions are presented in Figures E.1b to E.7b. Figures E.lc to E.7c show a family of cost curves based on the estimated price-size and price-efficiency parameters for each technology. 

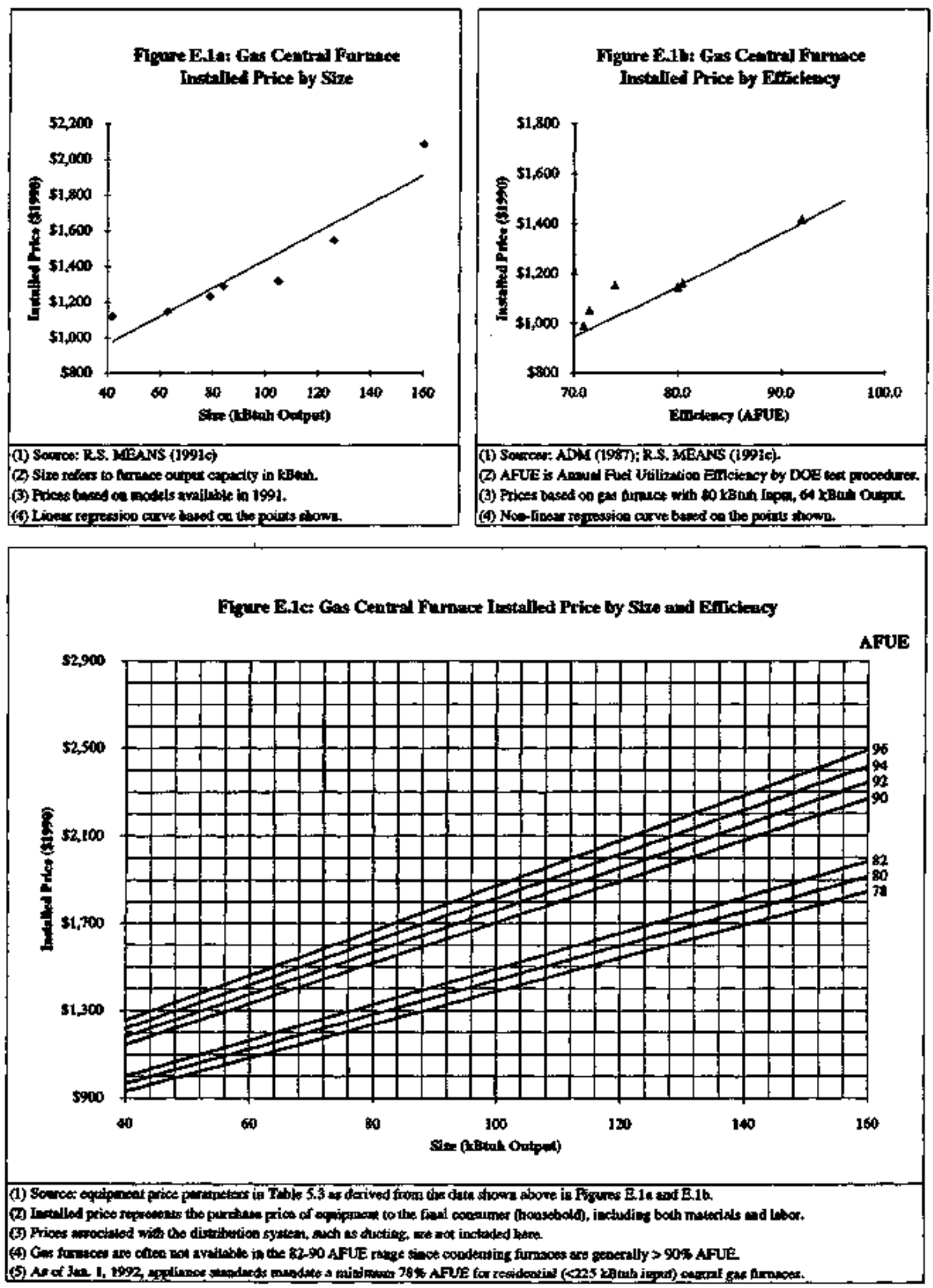

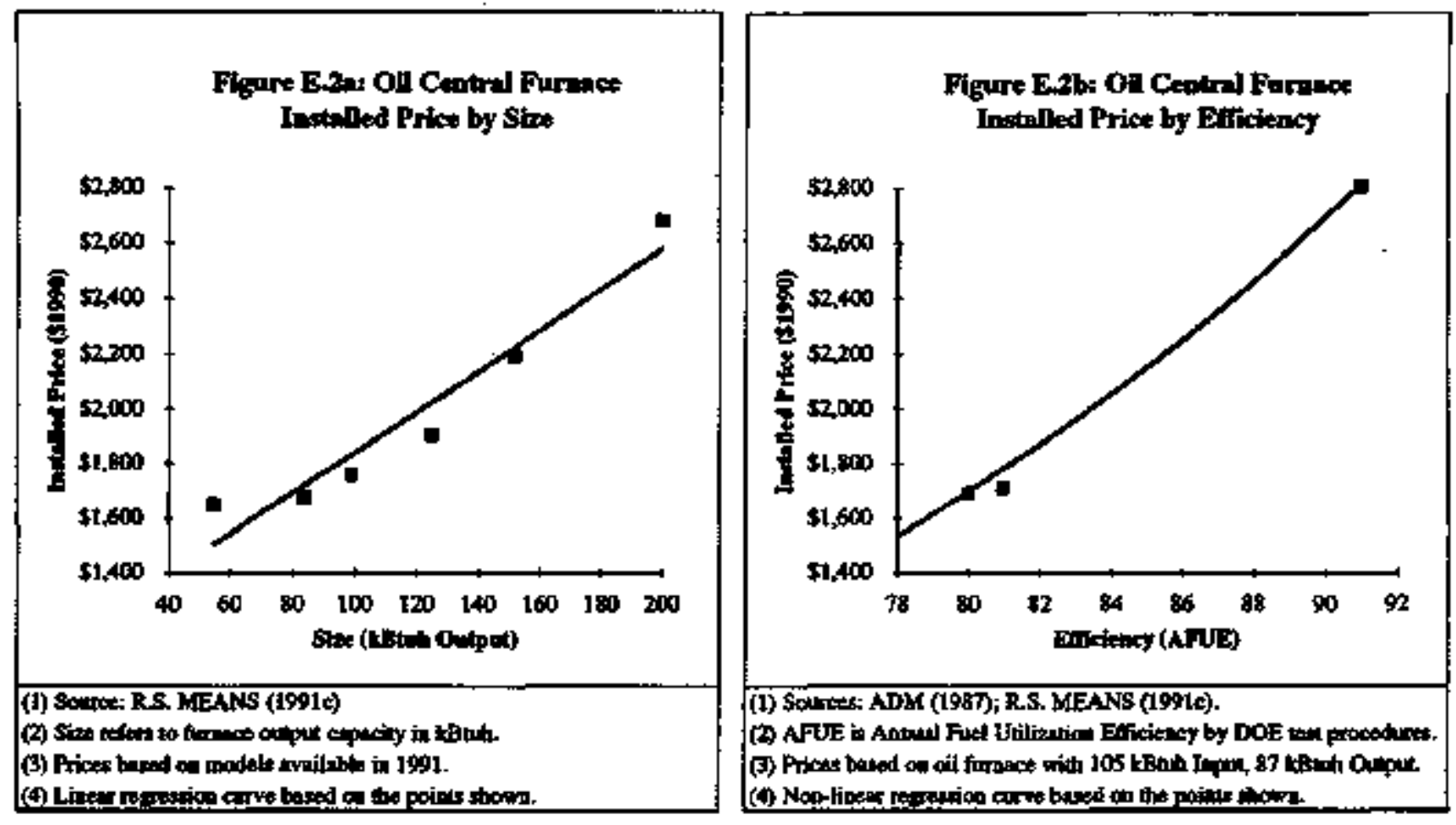

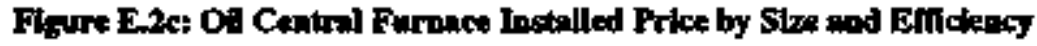

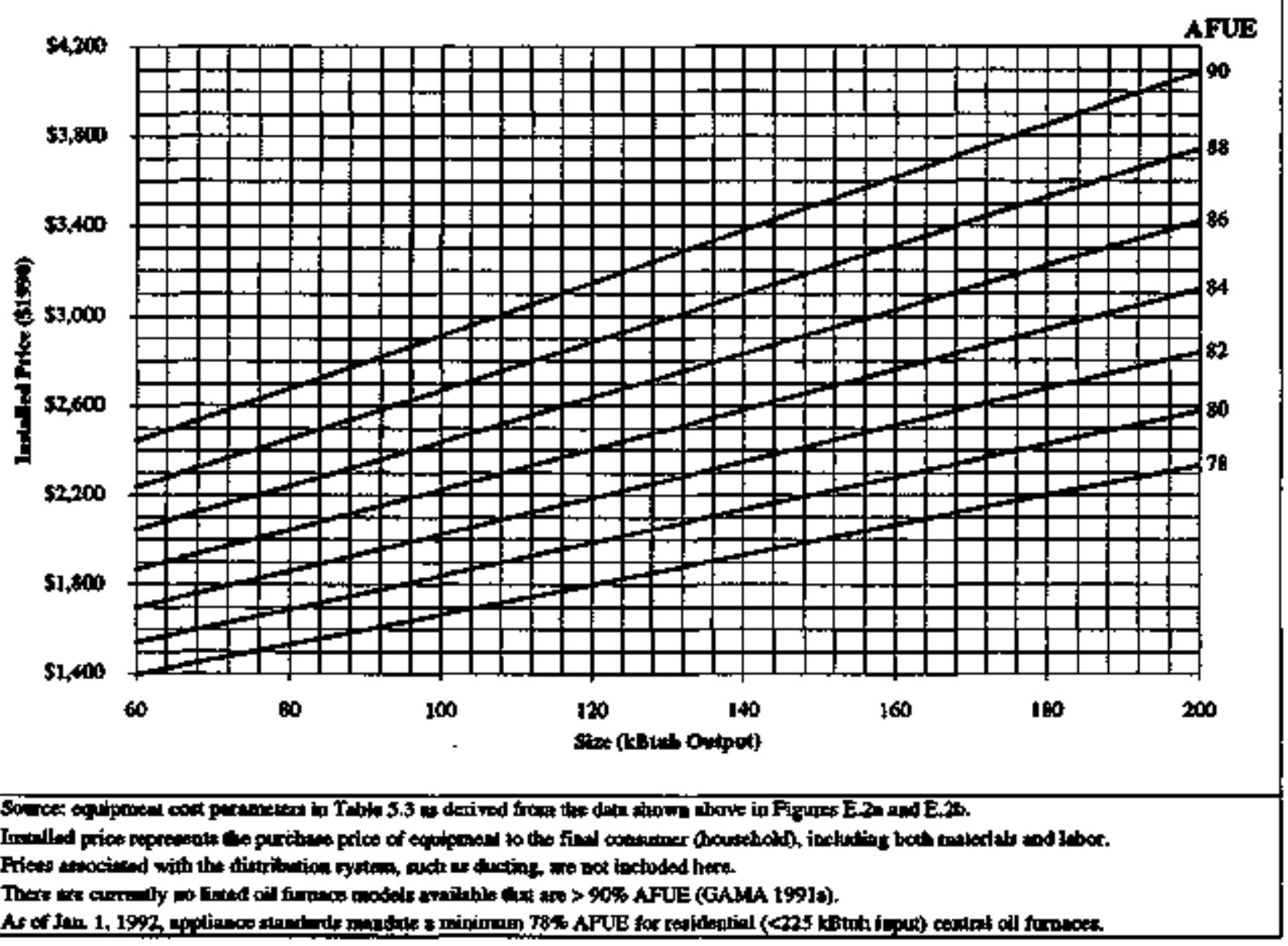




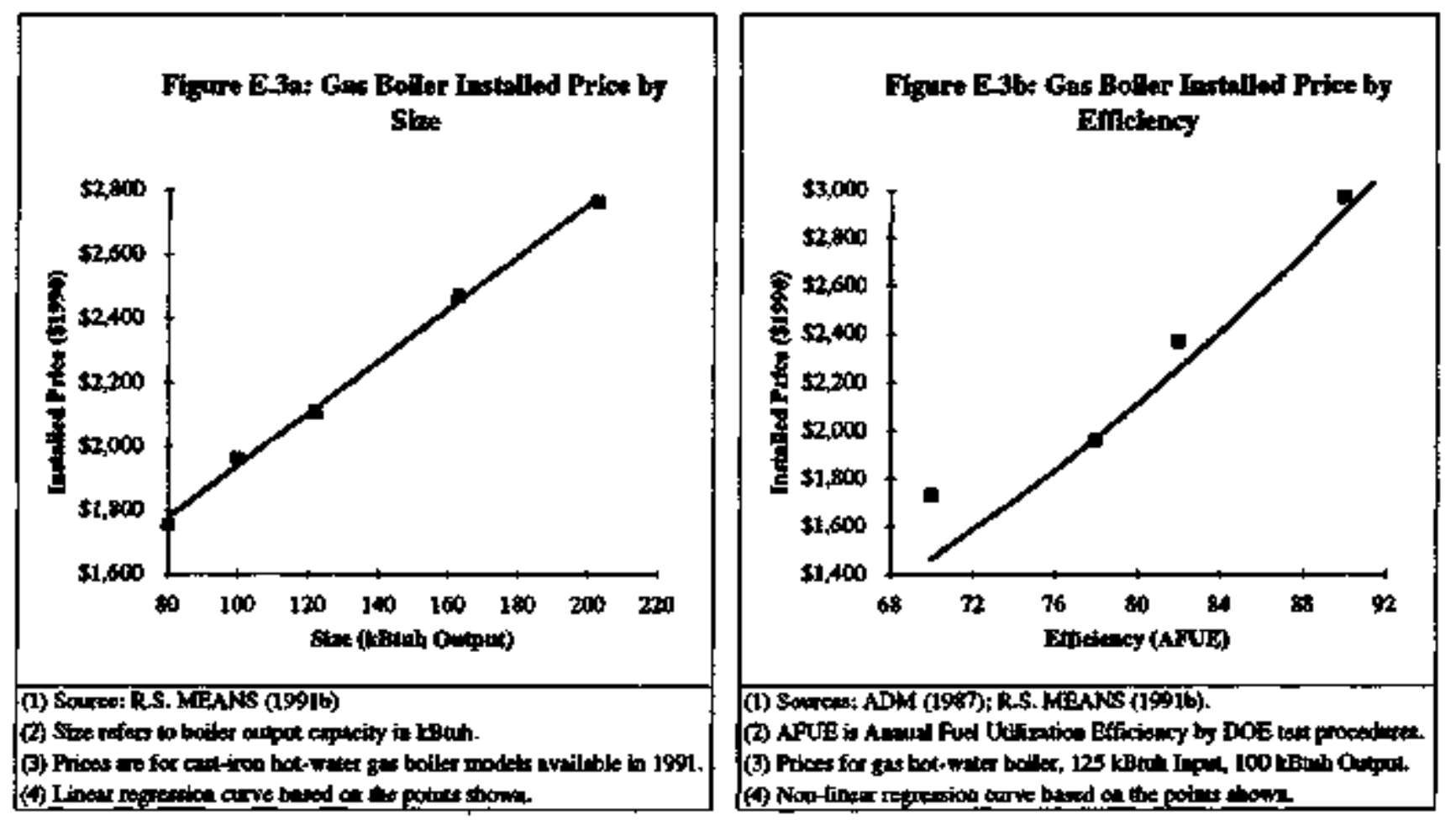

Fupre Ewat Ges Boilers Installed Prize by Sire and Eiilciacy

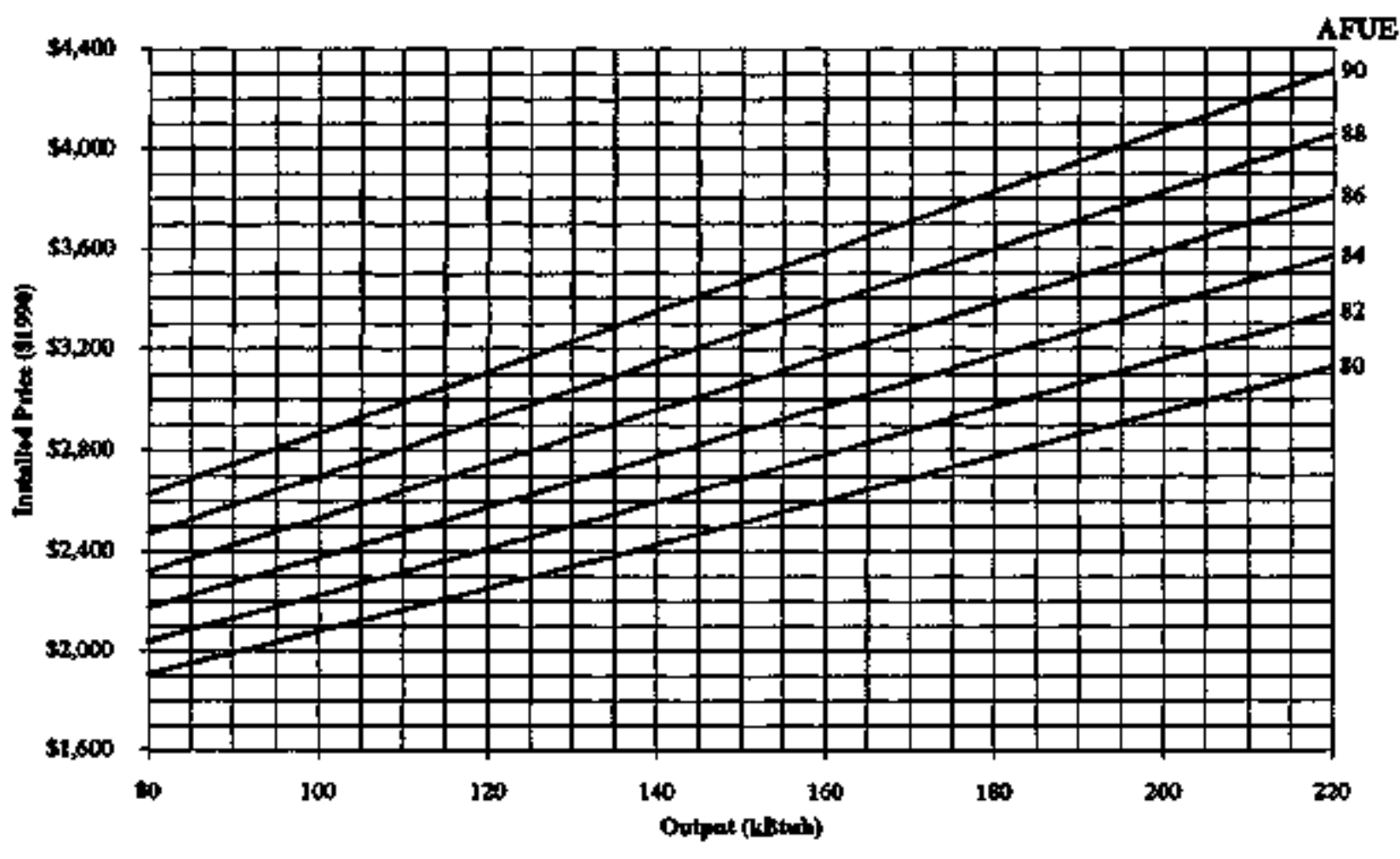

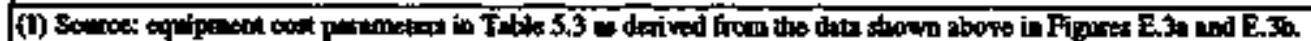

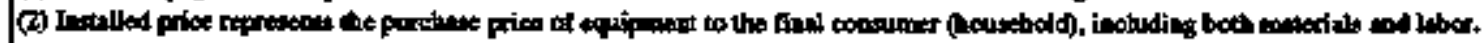

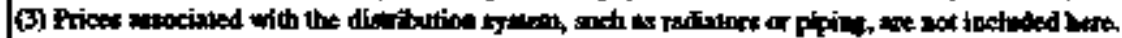

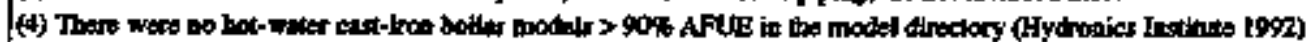

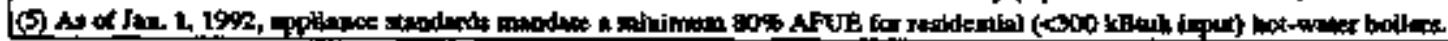




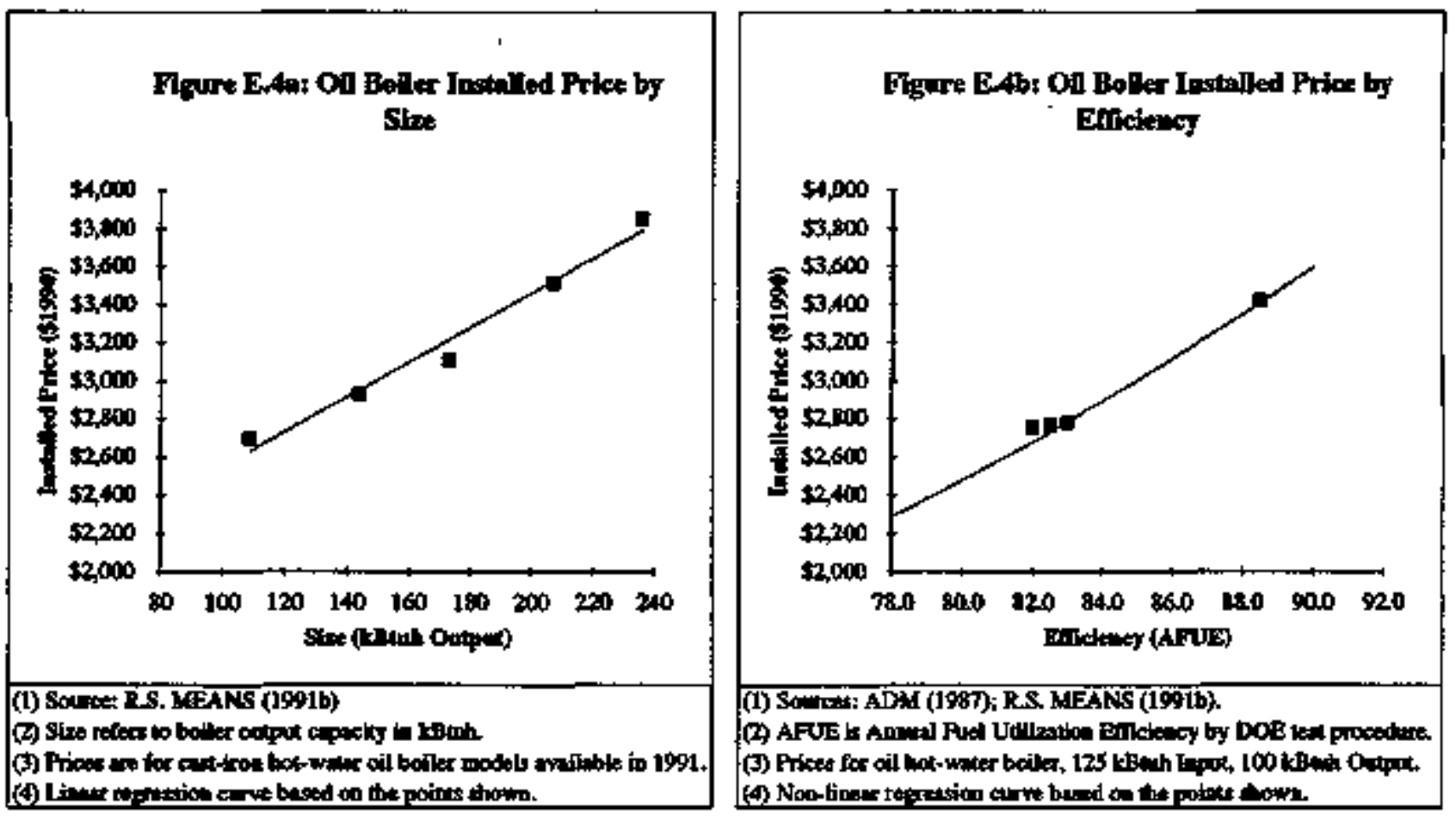

Figure EAct On Poiler Installed Prioe by Size and Eiticiency

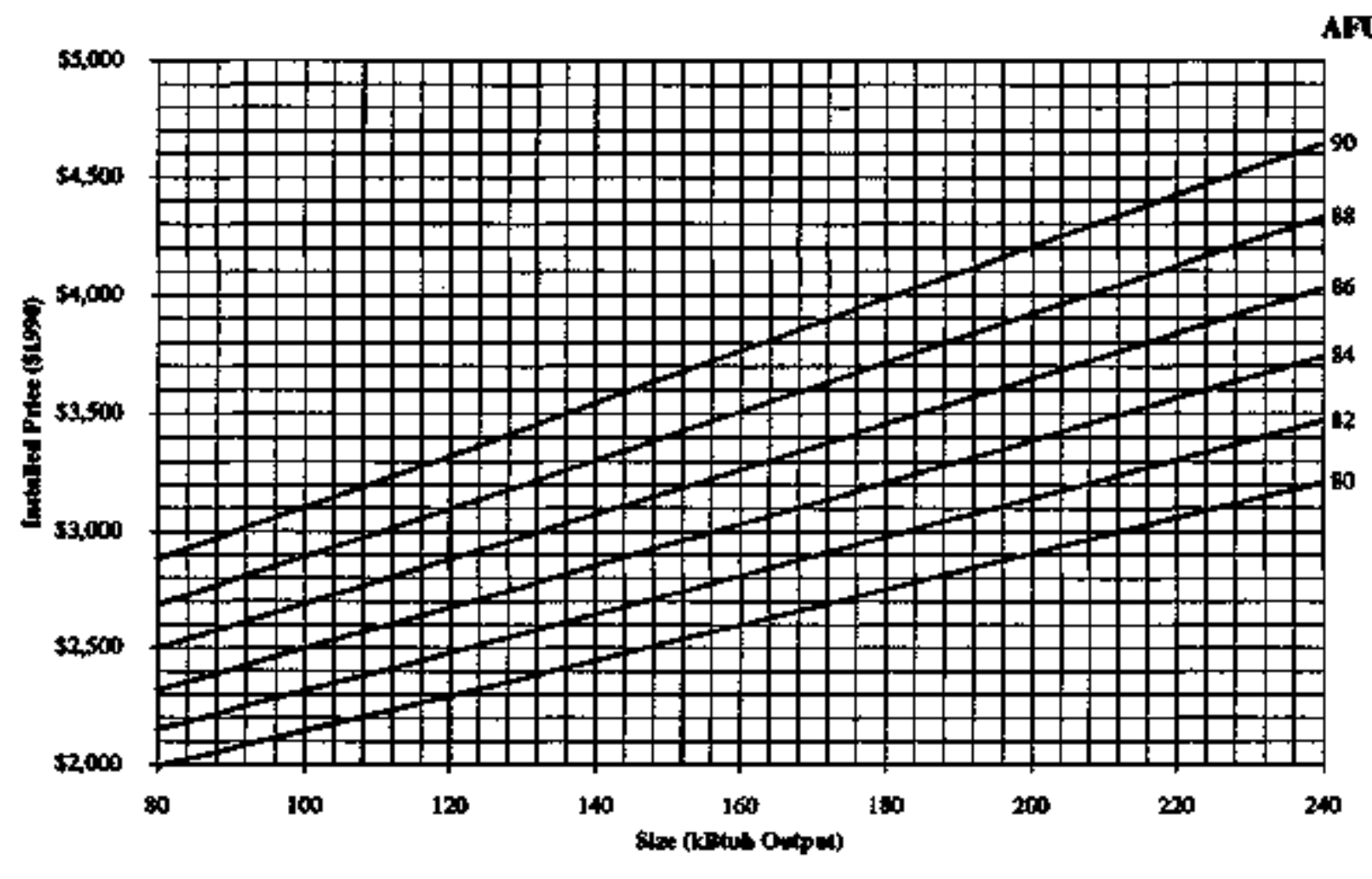

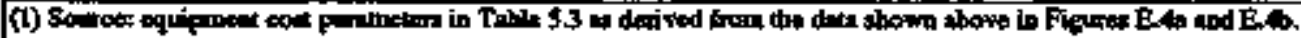

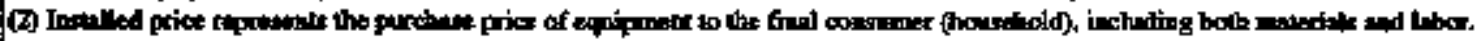

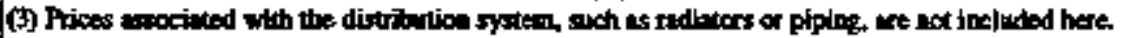

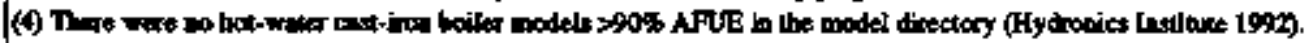

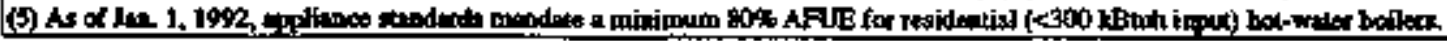



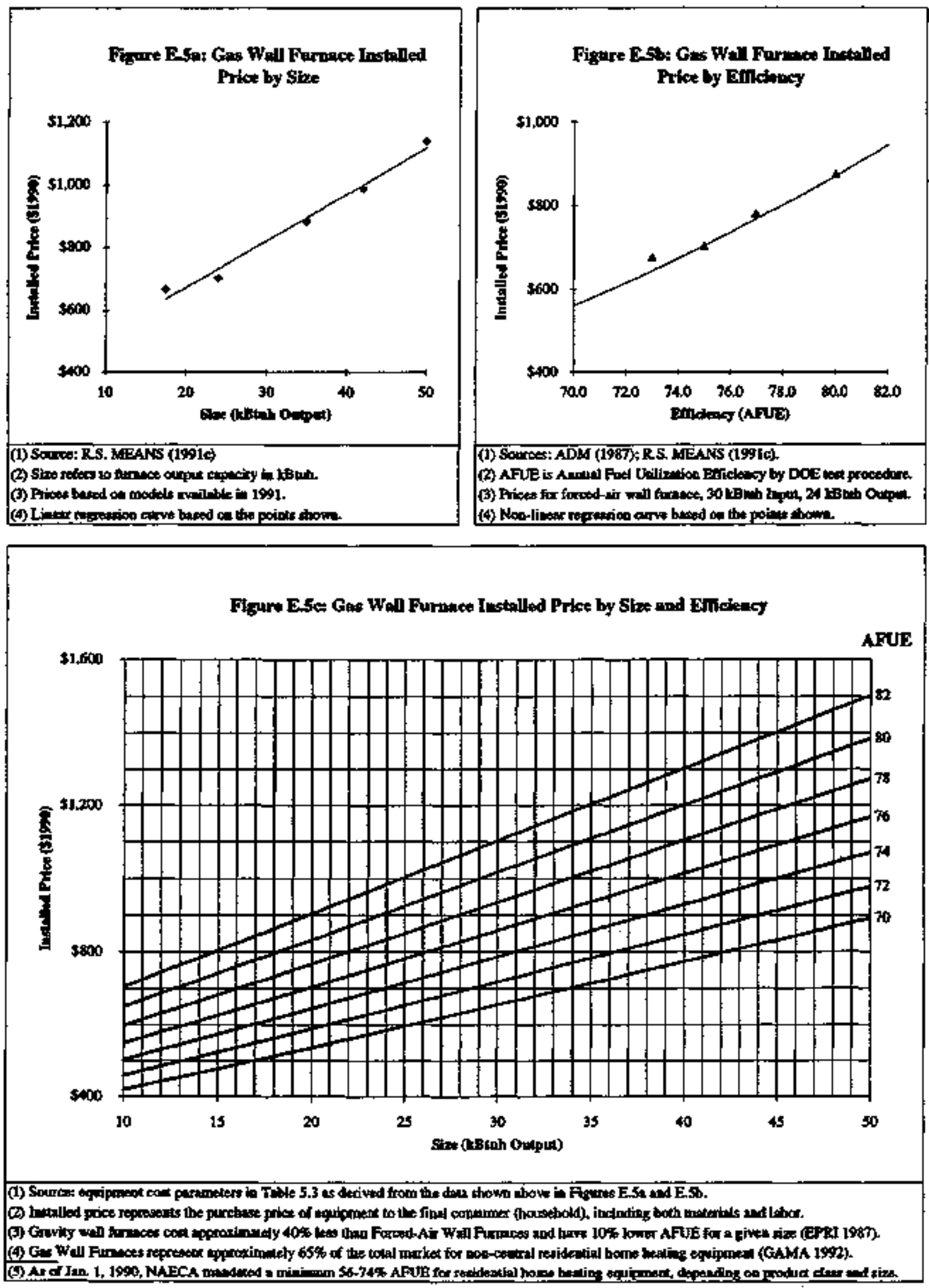

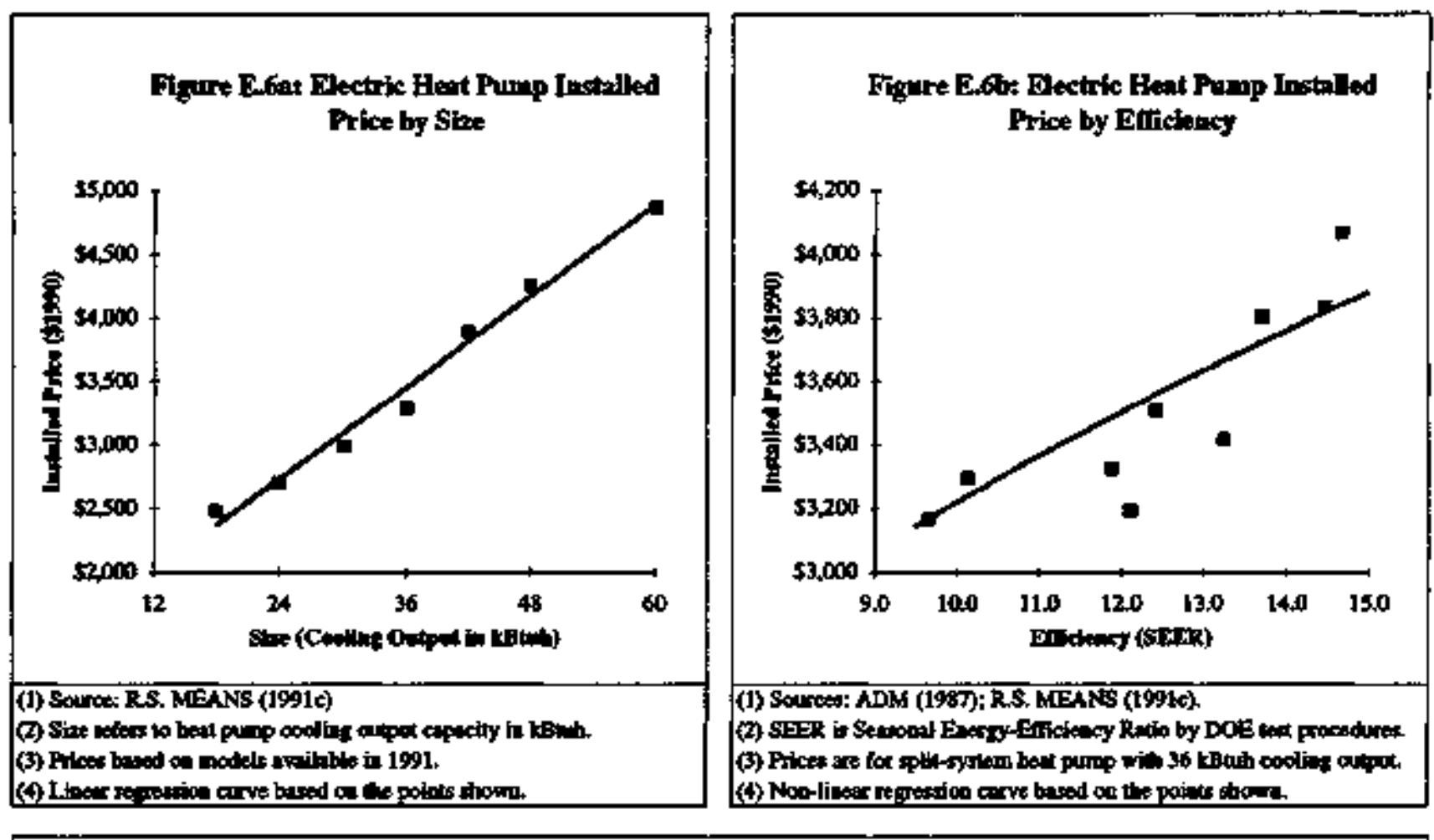
(1) Source: ADM (1987); R.S. MEAN' (t991c).

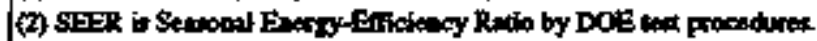

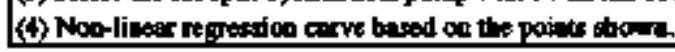

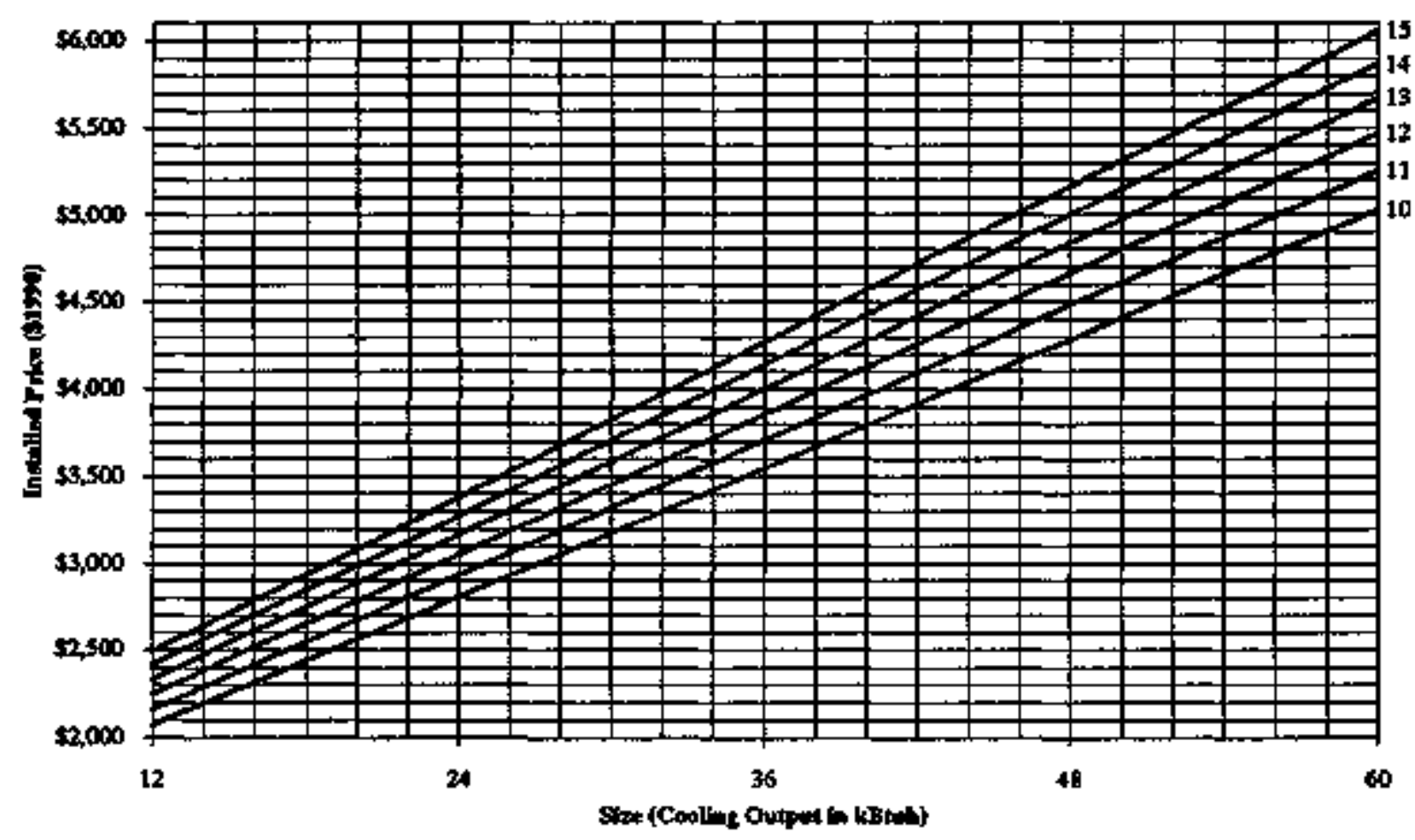

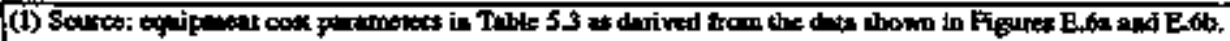

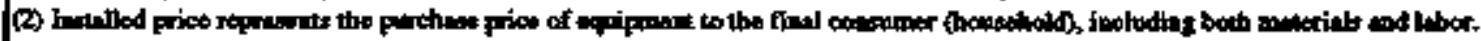

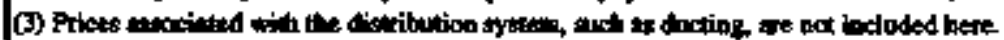

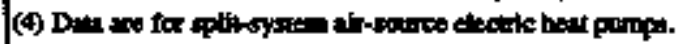

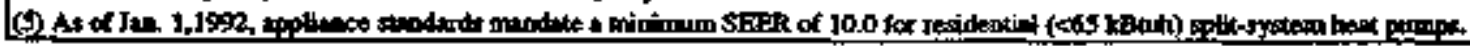



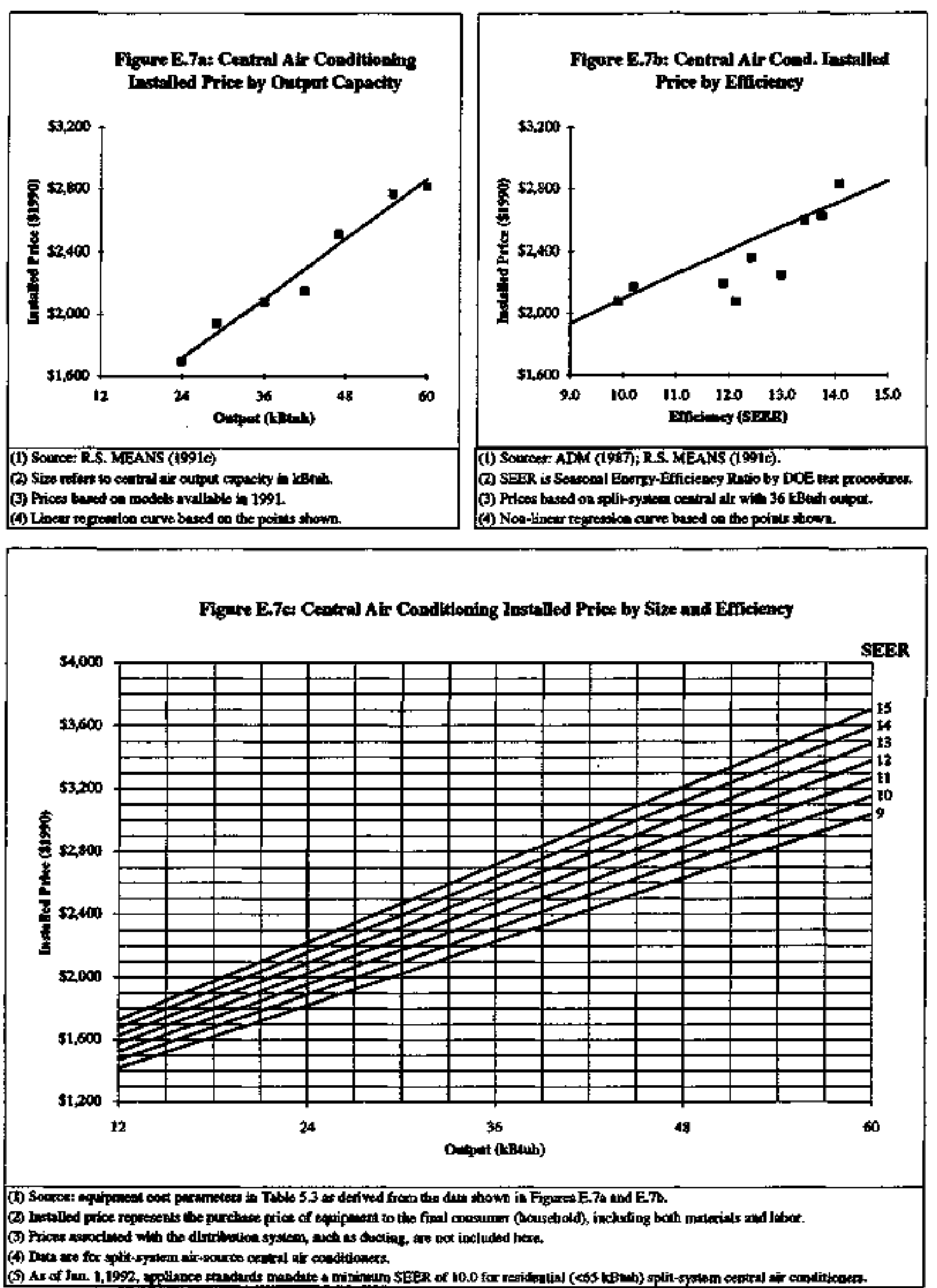


\section{APPENDLX F: REGIONAL HVAC SYSTEM CHOICE MODELS}

In addition to the National HVAC system choice model documented in Section 6.3, we have also estimated separate logit parameters for North and South HVAC models. The procedures we used to estimate the regional parameters are very similar to the procedures used in the National version, as described in Section 6.3. In fact, the steps required to prepane the data for the logit estimation are nearly identical. The main difference lies in the econometric estimation method itself. A maximum likelthood estimation technique using the SST statistical program (Dubin and Rivers 1988) was used rather than Betkson's method. We believe that Berkson's method is more appropriate for grouped data, but we were not aware of this specialized technique at the time these regional estimations were performed.

As is the case with the National HVAC equipment choice model, only aggregate (and averaged) data were available to estinate the regional models. Consequently, we developed a grouped data set based on the market share of beating equipment in new homes (1980s) in the 1990 RECS, and applied a multinomial logit algorithm to this data set to estimate the decision model parameters. The average heating load for each system was calculated from the thermal shells and component loads specified in Section 3, to which we applied the peak heating load equation and sizing factors from Section 5.1 in order to determine installed equipment sizes. The purchase price for each system was based on this calculated size and the average efficiency for each equipment type, using Equation 5.4. The operating expense was determined from the UEC for each technology, using Equation 6.5. The resulting data sets are shown in Tables F.1 and F.3. These data were then used to estimate a suitable set of parameters according to the standard utility equation from Equation 6.1. Appendix $G$ provides more detail on the supporting theory used in the model estimation.

We experimented extensively to obtain reasonable estimates, testing various specifications of alternative-specific constants as well as different definitions of the price variables. With our data, the constants serve in several cases to ensure that the signs of the price coefficients are negative (the most basic criteria for evaluating the estimates, as noted previously). In several cases, as the data in Tables F.1 and F.3 indicate, a system option that dominates one or more other options in both price elements (in other words, has a higher life-cycle cost at any positive discount rate) is observed to have a higher market share. This indicates the presence of significant unobserved factors in consumers' choices. In such cases, assigning a constant to either the dominated or dominating option may be necessary to obtain sensible results.

In order to estimate the parameters, the equipment prices were normalized to the average annual heating loads. For example, a gas furnace with purchase price of $\$ 2000$ in a region with a heating load of $100 \mathrm{MMBtu}$ would have a normalized parchase price of $2000 / 100=\$ 20 \mathrm{MMB}$. Previous studies have found that such a normalization is necessary to obtain reasonable estimates (Dubin 1985, Goett 1990). For single-family dwellings, the model parameters (including price coefficients and, as appropriate, alternative-specific constants) were computed for north and south regions of the U.S. and for two cooling choices (central air and no central air), yielding a total of four sets of parameters. The resulting parameter estimates are presented in Tables F.2 and F.4. Data limitations (specifically, number of zero market shares for certain choices) precluded the same level of estimation detail for the other dweiling types (multifamily and mobik home) 


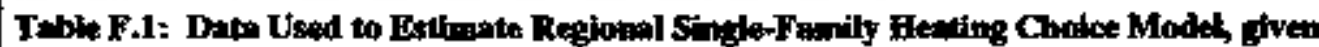
Central Air Conditioning

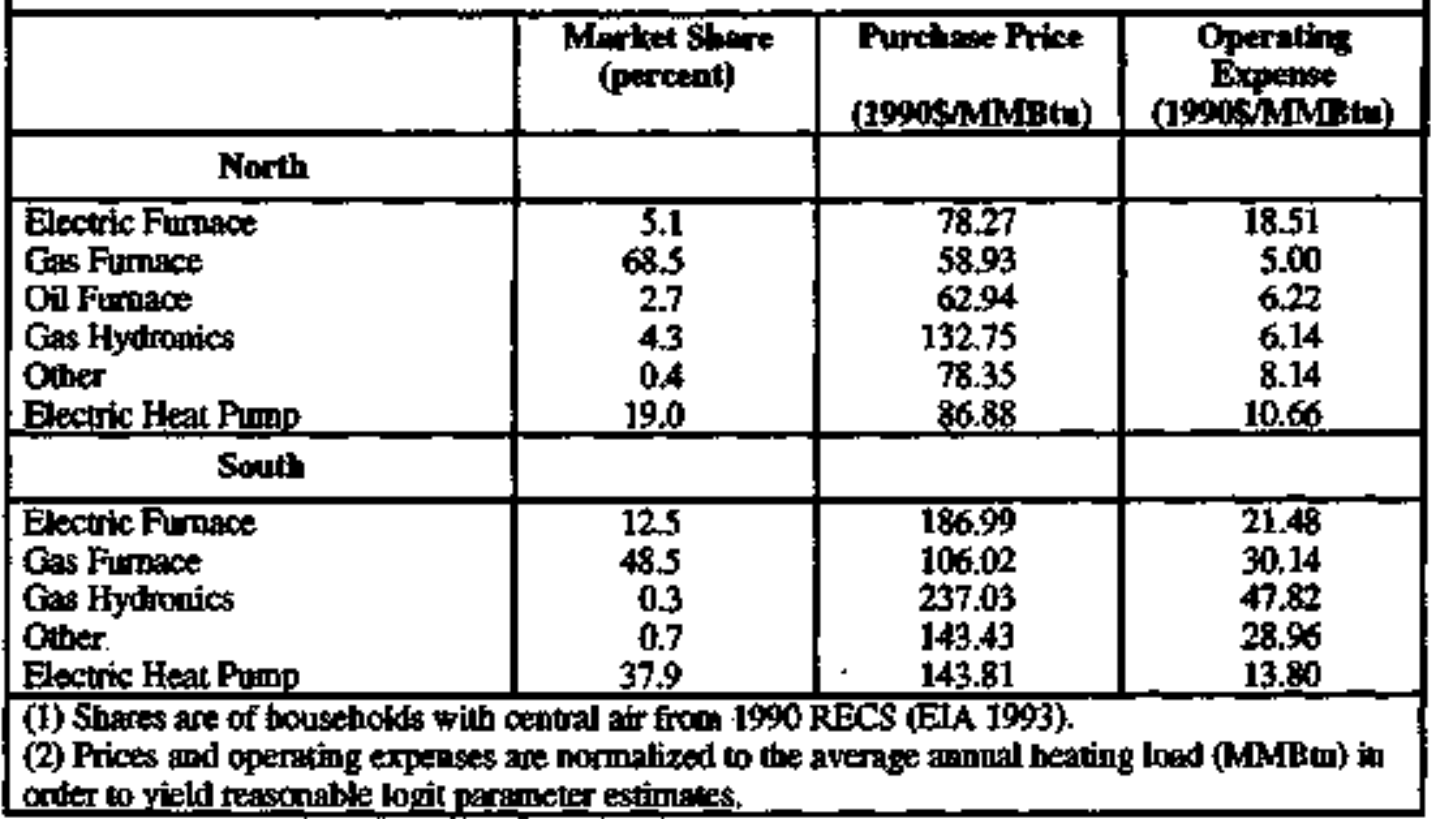

Table F 2: Estimated Coeticients of Single-Family FVAC Equipinent Clviee Model, Gwen Central Atr Conditioning

\begin{tabular}{|l|l|l|c|}
\hline \multicolumn{1}{|c|}{ Region } & $\begin{array}{c}\text { Purchuse } \\
\text { Price }\end{array}$ & $\begin{array}{c}\text { Operating } \\
\text { Espense }\end{array}$ & r \\
\hline North & -0.031 & -0.126 & $24.6 \%$ \\
South & -0.0321 & -0.7436 & $4.3 \%$ \\
\hline
\end{tabular}

(I) The implicit disconvt race, 1 , is calculated assuming infinite device lifetione, using Equation 6.2.

(2) Analysis is based co market share data from 1990 RECS (EIA 1993) and equipment price and operating expense estimation methods described in Section 63 


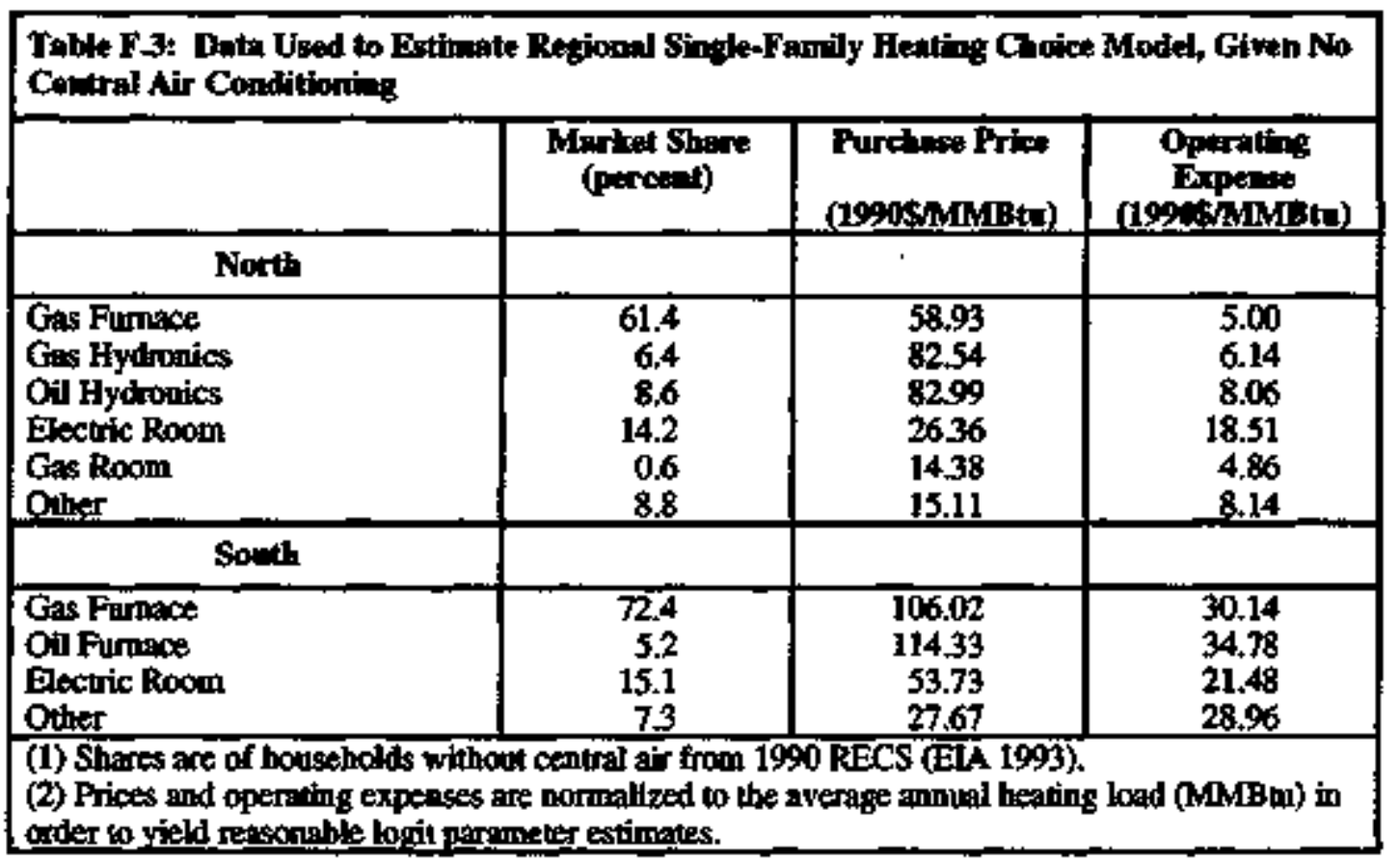

\begin{tabular}{|c|c|c|c|c|c|}
\hline \multicolumn{6}{|c|}{ 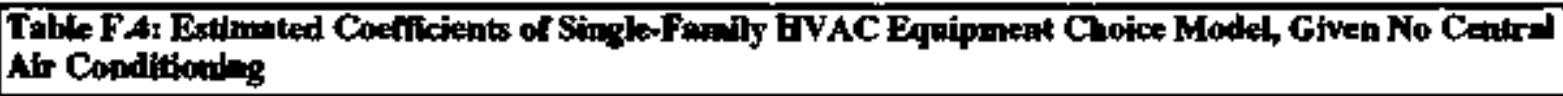 } \\
\hline Region & $\begin{array}{l}\text { Parchuse } \\
\text { Prtice }\end{array}$ & $\begin{array}{l}\text { Oparifing } \\
\text { Enpense }\end{array}$ & $\begin{array}{c}\text { Constont } \\
\text { (Gos Roonit) }\end{array}$ & $\begin{array}{l}\text { Constant } \\
\text { (Other) }\end{array}$ & $\mathbf{r}$ \\
\hline North & -0.0635 & -0.2587 & -7.7828 & -3.8923 & $24.6 \%$ \\
\hline Swoth & -0.0281 & -0.0380 & tha & na & $73.9 \%$ \\
\hline \multicolumn{6}{|c|}{ 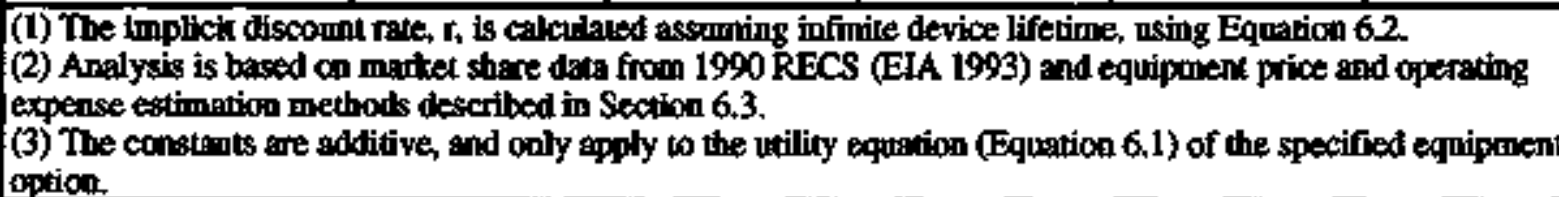 } \\
\hline
\end{tabular}




\section{APPENDIX G: QUALTTATIVE CHOICE ANALYSIS}

Qualitative Choice Analysis (QCA) provides the theoretical framework for the HVAC decision models we adopted in this analysis. In this appendix, we provide a brief overview of several key ideas of QCA. The material herein is taken primarily from Train (1986) and from notes from a workshop sponsored by the Econometrics Laboratory on the U.C. Berkeley campus (McFadden et al. 1992).

Two of the hallmarks of neo-classical economic analysis are a focus on aggregate - that is, market-level-phenomena and the assumption of continuity (and usually differentiability) of the variables under study. The latter assumption is reflected both in the basic theory of consumer choice, including the assumption of smooth indifference curves, and in the econometric estimation of market demand functions; at the market level, where individual differences are too fine to be captured, the modeling assumption of continuity is generally thought to be a good approximation to reality.

It is arguable, however, that 1) phenomena such as aggregate demand, being just the sum of many individual decisions, should ideally be studied with methods that explicitly capture individual-level tehavior, and 2) at the level of the individual, many if not most real-life choices have a discrete rather than continuous quality to them. Thus, for example, a consumer baying a reffigerator will ultimately choose between, for example, manual defrost and auto defrost, rather than some combination of the two. In buying a car, a consumer must ultimately purchase a Toyota or a Honda or a Ford or a Chevrolet-not some combination of the four. Qualitative choice analysis was devised for the economic analysis of such situations. Train describes QCA as "Tone of a variety of] methods for examining the behavior of individuals when continuous methods are inappropriate." "Methods" here refers to both a theoretical or conceptaal approach to the choice problem and to the econometric techniques that have been developed for this type of analysis.

Before providing a more technical description of these methods, an informal discussion may be helpful To begin, the individual ("consumer") is seen, as saggested above, as choosing one from among a number of discrete alternatives. The individual is conceived of as a decision-making "black box:" she evaluates the options in terms of their various features as well as her own preferences, and chooses what she considers the best alternative (in economic terms, the one that maximizes ber utility). So for example, she may be choosing between a manual and an autodefrost refrigerator; she will (in some manner that is left unspecified) evaluate, for example, the parchase prices, operating costs, convenience features, colors, styles, and possibly other features, and then choose one in a way that may also depend on such factors as her incone or beliefs. Several things about this picture deserve emphasis. First, exactly "how" the docision is made-for example, the psychological process involved--is essentially ignored by saying that the decision is a matter of "maximizing utility." (This approach is, of course, characteristic of economic modeling.) Furthermore, in this way in thinking, the decision-maker is a deterministic black box; that is, the output (the decision) is a non-probabilistic function of the inputs (the features of the alternatives and her own characteristics).

As the reader may know, however, QCA models themselves are probabilistic in nature. The idea is that the observer cannot possibly see everything that went into the decision, such as "beliefs." So the observer can, in principle, predict only imperfectly what decision will be made even knowing such things as certain characteristics of the alternatives and the decision-maker. The probabilistic elements of QCA arise from this state of partial ignorance of the observer. In 
particular, the aim of QCA models is not to elicit or to study (directly, at least) the form of the function transforming inputs into decisions. Rather, it is to derive monerical estimates of the probabilities that the decision-maker will make various choices, given certain assumptions about (among other things) the form of the decision-maker's utility function, and given observations of the decision-maker's actual choices and information about the decision-maker herself. There are several interpretations of what concept of "probability" is at work here. One can think, for example, of a decision-maker repeatedly facing the same choice; then the probability that a particular altemative will be chosen can be interpreted as the limiting proportion of the number of times that alternative is in fact chosen as the number of repeats becomes "large." Or, one can think of a number of decision-makers with the same observable characteristics being observed, sequentially, facing the same choice sitoation; then the probability can again be interpreted as a limiting proportion. The point is, again, that the probabilistic nature of the models is interpreted in tems of the relationship between the observer and the decision-maker, QCA models are not models of "decision-making under uncertainty" as these are typically defined in econonics or operations research.

To begin a more precise description, the technical specification of the decision-maker's situation is that the possible altematives form a finite partition of her universe of choice, that is, the alternatives are a) finite in number, b) mutually exclusive, and c) exhaustive (that is, she must choose one and only one alternative). It is often possible to adjust the model so that these conditions are satisfied in situations in which they are not readily apparent.

Now suppose one wishes to analyze some such situation, for example, a choice among appliances or cars. Following is a description of the generic qualitative choice model (Train's notation will be tused for the duration). A particular decision-maker will be indicated by the index $n$.. Denote the set of altematives she faces by $J_{n}$, the observed (by the researcher) characteristics of alternative $i$ as faced by decision-maker $n$ as the vector $z_{i n}$, and the observed characteristics of the decision-maker as the vector $S_{n \text { - }}$ Then the probability that decision-maker $n$ chooses altemative $i$ is a parametric function of the form

$$
P_{m=}=f\left(z_{n}, z_{j=} \forall j \in J_{n}, j \neq i, s_{n}, \beta\right),
$$

where the expression " $\forall j \in J_{n}$ " means "for all $j$ in $J_{n}$ " and $\beta$ is a vector of parameters. This equation describes, conceptually, the overall framework of QCA analysis. The details and the applications have to do primarity with first specifying the function $f$ and then estimating the vector of parameters.

The first step in implementing this abstract framework is to examine more carefully the relation between what the decision-maker is doing and what the observer is seeing, and to introduce notation that reflects this distinction between "observable" and "unobservable." We write the utility that decision-maker $n$ derives from selecting aftemative $i$ as a function of $x_{i n}$, the relevant characteristics of the altemative, and $r_{i}$ the relevant characteristics of the decision-maker, thus,

$$
U_{i n}=U\left(x_{i n}, r_{n}\right)
$$

for all $i$ in $J_{n}$. Here, $U$ is a function whose form we have yet to describe. We partition $x_{\text {; }}$ into those characteristics of the alternative that are observed by the researcher, labeled $z_{\text {in }}$ as before, and those that are not (and are left anlabeled), and we partition $r_{n}$ into characteristics of the decision-mater that are observed by the researcher, labeled $s_{\text {, }}$ as before, and those that are not (and again are left mlabeled). Finally, we break up $U\left(x_{i n}, r_{n}\right)$ into an observed component that is 
known up to a vector $\beta$ of parameters to be estimated and that we label $V\left(z_{i n}, s_{\pi}, \beta\right)$, and an unknown component which we label $e_{\text {in }}$. Then we can write the utility derived by the decisionmaker from alternative $i$ as

$$
U_{\mathrm{in}}=V\left(z_{\mathrm{in}}, s_{\mathrm{n}}, \beta\right)+e_{\mathrm{Ir}}
$$

At this point, a more concrete specification can be provided. To apply the general scheme, one needs to furst view $\ell_{\text {in }}$ as a random variable, and specify a particular form for it, and second to specify a particular form for the observable (or "tepresentative") atility $V\left(z_{i,}, s_{*}, \beta\right)$. Different qualitative choice models, such as logit or probit, arise from particular specifications of the random variable. For our purposes, the model of interest is the logit The logit model is obtained by assuming that the error terms $e_{i n}$, where the index $i$ ranges over all alternatives in $J_{n}$, are independently and identically distributed accorfing to the extreme value (also called "Weibull") distribution. (The adjective "multinomial" in this context simply means that more than two altematives are available.) In addition, in our applications (and in many others) it is assumed that the observable utility function is linear, that is, we assume that this function is of the form

$$
V_{\mathrm{h}}=\beta w\left(z_{\mathrm{in}}, s_{\mathrm{n}}\right)
$$

where $w$ is a vector function of the observable data and $\beta$ is, as before, a vector of parameters. (Note that the expression $\beta w\left(z_{n}, s_{n}\right)$ is a vector or inner product.) If we suppress the functional dependence of the function $w$ on the data and simply write is as $w_{b}$, then it can be shown that the probabilities take the form

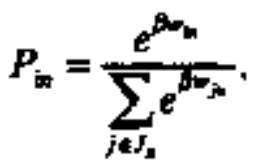

(Note that two steps have been combined into one here; the logit probabilities always take this form of "exponential divided by sum of exponentials;" the exponents themselves are the representative utilities, which in the case just written-wbut not in general-o are linear:)

There are several things to note about this last expression. First, the probabilities defined in this way sum to one (as they should). Second, if one graphs $P_{j}$ as a function of $w_{i n}$, the familiar " $S$ shaped" or logit curve is obtained. (This is also true more generally, that is, it doesn't depend on the linearity of representative utility.) Third (actually a corollary of the latter observation), probability is a (highly) non-linear function of the data; this is the source of the oft-mentioned caution against constructing a model of this form and then plugging averaged data into it.

Another point is worth noting here: the primary reason for the particular stochastic specification that gives rise to the logit (that is, independent and identically distributed Weibull) is "analytical tractability." The probit model is based on the more natural assunption that the error terms have a joint moltivariate normal distribution with a general variance-covariance matrix. This model, however, gives rise to some very difficult integrals in the expressions for the choice probabilities, with attendant estimation problems. (Hausman used a probit model in his famous 1979 air conditioner choice paper, which is a good example of that type of approach (Hausman 1979))

We will now write down how the above fortalism looks in an example. Suppose that a decision-maker--a household--is to choose between a gas and an electric oven, and that we 
decide that the decision will be made on the basis of (or, "utility depends upon") the purchase price and operating cost, which we can observe, and upon the household's view of other characteristics of the ovens, such as appearance, quality, and so forth, which we can't observe. If we also assume that observed utility is a linear function of these factors, then we can write the utility of the two choices, respectively, as

$$
U_{t}=\beta_{1} P P_{t}+\beta_{2} O C_{t}+e_{s} \text { and } U_{r}=\beta_{t} P P_{t}+\beta_{2} O C_{r}+\varepsilon_{r} \text {, }
$$

where the subscripts indicate gas and electric, respectively, PP is purchase price and $O C$ operating cost, and the beta's are scalar parameters. If the error terms are distributed Weiboll, then the probability that the housebold chooses the gas oven is

$$
P_{g}=\frac{e^{\beta_{1} e P_{2}+\beta_{2} O C_{s}}}{e^{\beta_{1} F_{r}+\beta_{2} O C_{2}}+e^{\beta_{k} B P_{r}+\beta_{2} O C_{r}}},
$$

and the probability it chooses electric is analogous.

The parameters in the logit models are estimated by maximum likelihood methods (given certain assumptions on the character of the sampled data). Briefly, these are statistical optimization methods in which the maximization of what is called a "(log) likelihood function" yields the values of the parameters that give the highest probability that the decision-makers made the choices that are actually observed. The log likelihood is also used to construct what is called the "likelihood ratio index," which is a measure of goodness-of-fit and can be used in hypothesis testing. In addition, standard hypothesis tests can be performed on individual parameters using the t-test.

One important elaboration of the basic logit model that we should mention briefly is the adding of constant terms--so-called "altemative-specific constants"-to the linear-observable utility functions. This has several important functions. First, it corrects the (probably false) assumption that the errors have zero mean (which is a feature of the standard Weibull distribution). In this sense, it is like adding intercept terms in a linear regression. Second, when the parameters are estimated, it results in observed proportions in the sample being reproduced exactly in the model. Third, it allows up to a certain point for the correction of a central potential flaw in the underlying model, which we now discuss.

One mathematical consequence of the logit model is a property called "the independence of irrelevant alternatives (IIA)," which means that according to the model the ratio of the probabilities associated with any two choices is independent of any other alternative. Conceptually, this property enables one to correctly estimate a model on onIy a subset of observed alternatives, and also, given an estimated model, to predict demand for new altermatives.

There are some situations in which IIA may hold for some pairs of alternatives but not for others, or, put another way, there are "nests" of alternatives for which ILA holds. Another qualitative cholce mortel, the "GEV" (for "generalized extreme value") or "nested logit" is appropriate in these situations. The GEV model is derived from the assumption that the error terms as described above--the $e_{\mathrm{m}}$--are distributed in accordance with a generalized extreme value (or GEV) distribution. Under this assumption, one can derive expressions for the choice probabilities that ane analogous to those in the logit (and reduce to them in the case whers the eiror terms are uncorrelated) but are mone elaborate; we won't write down the general form here. GEV models can also be estimated globally by maximum likelihood techniques, More common, however, is to perform a "bottom-up" sequential estimation (imagine bere the usual upside-down 
"tree" diagram with two levels) starting at the lower or "nest" level; this exploits the fact that GEV choice probabilities can be decomposed into conditional and marginal probabilities that are logit.

There are several ways of obtaining aggregate (i.e., population) estimates from QCA mokieis. The most straightforward is sample enumeration. Each individual in the sample is given a weight $w$. (where the subscript $n$ corresponds to the individual) depending on the characteristics of the sample, assuming "exogenous" samples, i.e., random or stratified random samples in which the strata (if any) are exogenous to the choice being studied. If the sample is random and consists of $N$ observations, the weight is $1 / N$ for each individual; if the sample is stratified, the weight varies over strata but is the same for all individuals within strata. In any case, the average probability for alternative $i$ is estimated as

$$
\bar{P}_{i}=\sum_{i} w_{r} P_{i}
$$

and the number of individuals in the population predicted to choose alternative $i$ is estimated as

$$
N_{i}=N \vec{P}_{i^{*}}
$$




\section{APPENDLX H: NATIONAL HVAC MODEL}

In addition to the two regional REEPS HVAC models described in this report, we have also developed a national HVAC model for use in quick reaction analyses. In general, identical methods and data sources were used to develop both models. The three main differences between the disaggregated (North and South) and national models are: 1) climate, 2) UECs for HVAC equipment, and 3) the namber of housing types ${ }^{1}$. In executing the models in the REEPS environment, the main difference is the reduced time required to set-up the national model inputs and the elimination of the need to aggregate the results. Despite the potentially more accurate forecast results of the regional models, the national model offers distinct advantages in being quicker to develop and nun. The last section of this appendix describes how to select the most appropriate version of the HVAC model for particular applications. We maintain both the regional and national versions of the model for use in a variety of modeling situations.

The following sections describe the ways in which development of the national model differed from the regional models, and present the inputs to the national trodel.

\section{H.1 Thermed Shell and HVAC Equipment Data}

The space conditioning loads were derived from the same database of simulated shell cornponent loads as the regional models. For the national model, we used the climate of Washington, D.C. to model the national average space conditioning loads. Building characteristics were based on data from the 1990 RECS, as shown in Table H.1. As the table indicates, the national model bas three house-types. The space conditioning load attributed to each of these shell components (in a national average climate) is shown in Table H.2. The themal shell components were combined to develop a set of thermal shell packages for the national model, as shown in Table H.3. The market shares of these shell packages are shown in Tables H.4 and H.5 for existing and new homes, respectively. The new constroction cost of each themal shell package is based on the component costs in Table H.6.

\begin{tabular}{|c|c|c|c|}
\hline & \multicolumn{3}{|c|}{ Housing Type } \\
\hline & Single-femily & Maltiffomily & Manuf. Homes \\
\hline \multirow{2}{*}{$\begin{array}{l}\text { Nominer of Staries } \\
\text { Foundation Type }\end{array}$} & 2 & 1 & 1 \\
\hline & \multicolumn{3}{|c|}{ Uahcated Basement } \\
\hline \multicolumn{4}{|c|}{ Componen Dinensions (square feet) } \\
\hline $\begin{array}{l}\text { Conditioned Floor Area } \\
\text { Ceiling } \\
\text { Walls } \\
\text { Windows } \\
\text { Inflitration } \\
\text { Foundation Area } \\
\text { Foudadation Perimeter (linear ft) }\end{array}$ & $\begin{array}{l}1744 \\
872 \\
1683 \\
209 \\
1744 \\
872 \\
118\end{array}$ & $\begin{array}{c}1074 \\
479 \\
476 \\
73 \\
3074 \\
31\end{array}$ & $\begin{array}{l}1205 \\
1205 \\
992 \\
145 \\
1205 \\
1205 \\
142\end{array}$ \\
\hline 1990 Stock (millions) & 60,4 & 24.5 & 6.1 \\
\hline \multicolumn{4}{|c|}{ 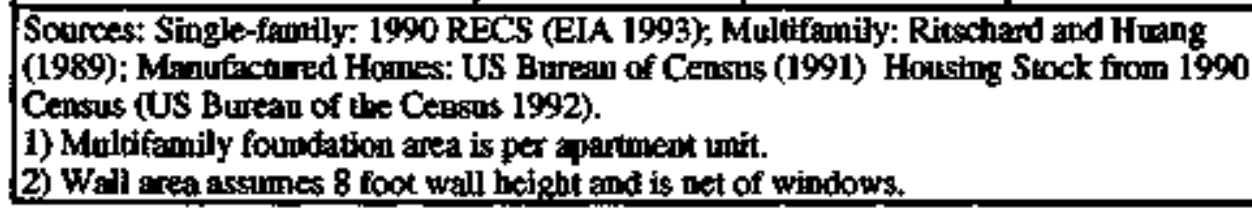 } \\
\hline
\end{tabular}

\footnotetext{
'The pational model has three bouse-types rather than the regional models' four house-types (the rwo sizes of singlefamily honses have been reduced to one). This allows the national HVAC and appliance models to be rim simultaneousty in the REEPS envirolanent, because both have the same house-type segmentation.
} 


\begin{tabular}{|c|c|c|c|}
\hline \multirow[t]{2}{*}{ Comproneat Descriptions } & \multirow[t]{2}{*}{ Component } & \multicolumn{2}{|c|}{$\begin{array}{c}\text { National } \\
\text { (Wasington, D,C) }\end{array}$} \\
\hline & & Heating & Cooling \\
\hline $\begin{array}{l}\text { Cefiting } \\
\text { (tBin/squt of ceiling) } \\
\text { ceiling insulation } \\
\text { R-value }\end{array}$ & $\begin{array}{l}R-0 \\
R-7 \\
R-11 \\
R-19 \\
R-22 \\
R-30 \\
R-38 \\
R-49 \\
R-60 \\
\end{array}$ & $\begin{array}{r}25.63 \\
10.21 \\
7.75 \\
5.54 \\
4.69 \\
3.55 \\
2.87 \\
2.26 \\
1.87 \\
\end{array}$ & $\begin{array}{l}7.04 \\
2.89 \\
2.23 \\
1.63 \\
1.39 \\
1.05 \\
0.85 \\
0.67 \\
0.55\end{array}$ \\
\hline $\begin{array}{l}\text { Woll } \\
\text { (kButsqfi of wall) } \\
\text { wall insulation } \\
\text { R-value }\end{array}$ & $\begin{array}{l}\text { R-7 } \\
\text { R-7 } \\
\text { R-11 } \\
\text { R-13 } \\
\text { R-19 } \\
\text { R-27 } \\
\text { R-34 }\end{array}$ & $\begin{array}{r}23.61 \\
11.59 \\
9.87 \\
7.78 \\
6.74 \\
4.86 \\
3.70 \\
\end{array}$ & $\begin{array}{l}3.53 \\
1.83 \\
1.59 \\
1.26 \\
1.09 \\
0.79 \\
0.52 \\
\end{array}$ \\
\hline $\begin{array}{l}\text { Siab } \\
\text { (kBtulin. ft of stab) } \\
\text { perimeter } R+\text { palat } \\
\text { and depth }\end{array}$ & $\begin{array}{c}R-0 \\
R-52 f t \\
R \cdot 54 \mathrm{t} \\
R-102 \mathrm{ft} \\
R-104 \mathrm{ft} \\
\end{array}$ & $\begin{array}{r}42.63 \\
18.89 \\
12.15 \\
14.50 \\
5.10 \\
\end{array}$ & $\begin{array}{l}-7.51 \\
-7.39 \\
-6.90 \\
-7.33 \\
-6.60 \\
\end{array}$ \\
\hline 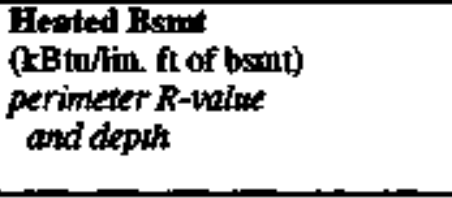 & $\begin{array}{r}R-0 \\
R \cdot 54 f \mathrm{f} \\
R-58 \mathrm{ft} \\
R-104 \mathrm{ft} \\
R-10 \mathrm{gft} \\
\end{array}$ & $\begin{array}{l}79.56 \\
52.51 \\
43.41 \\
45.52 \\
31.36 \\
\end{array}$ & $\begin{array}{l}8.28 \\
3.76 \\
3.40 \\
2.55 \\
1.89 \\
\end{array}$ \\
\hline $\begin{array}{l}\text { Enbeated Bant } \\
\text { (kBnisqh of thdn) } \\
\text { bederfoor R-value }\end{array}$ & $\begin{array}{l}\text { R-0 } \\
R-11 \text { fir } \\
R-19 \text { flr } \\
R-30 \text { flr }\end{array}$ & $\begin{array}{r}8.61 \\
1.34 \\
-0.65 \\
.1 .93 \\
\end{array}$ & $\begin{array}{l}0.89 \\
2.53 \\
2.97 \\
3.25 \\
\end{array}$ \\
\hline $\begin{array}{l}\text { Crtwispoce } \\
\text { (kBtu/sqfi of fnith) } \\
\text { underfoor R-value }\end{array}$ & $\begin{array}{c}R-0 \\
R-11 \text { fir } \\
R-19 \text { fir } \\
R-30 \text { flr } \\
R-38 \mathrm{ftr} \\
R-49 \mathrm{fr}\end{array}$ & $\begin{array}{r}15.10 \\
1.34 \\
-0.99 \\
-2.41 \\
-2.74 \\
-3.67\end{array}$ & $\begin{array}{l}3.04 \\
3.73 \\
3.83 \\
3.90 \\
3.91 \\
3.96\end{array}$ \\
\hline $\begin{array}{l}\text { Inflitration } \\
\text { (kBnu/sqfit of floon) } \\
\text { Air Changes per Hour (ACH) }\end{array}$ & $\begin{array}{l}0.80 \\
0.70 \\
0.55 \\
0.40 \\
\end{array}$ & $\begin{array}{r}14.62 \\
12.74 \\
10.02 \\
6.75 \\
\end{array}$ & $\begin{array}{l}1.73 \\
1.51 \\
1.20 \\
0.81 \\
\end{array}$ \\
\hline $\begin{array}{l}\text { Windows } \\
\text { (kBbisqut of window) } \\
\text { no. of panes/design }\end{array}$ & $\begin{array}{c}\text { 1.0-gla } \\
2.0-g \text { ga } \\
3.0 \text { gla } \\
\text { 2-gle loE } \\
\text { 2-gla loEAr } \\
\text { Spectral. Sel. } \\
\text { Sijperwindow } \\
\text { Heat Minor }\end{array}$ & $\begin{array}{r}63.9 \\
15.4 \\
-1.1 \\
6.4 \\
-0.0 \\
14.3 \\
-6.7 \\
9.5 \\
\end{array}$ & $\begin{array}{l}38.7 \\
27.4 \\
24.9 \\
24.2 \\
24.1 \\
18.1 \\
20.6 \\
15.9 \\
\end{array}$ \\
\hline Refidtal Lond (Śngle-family) & & 1.98 & -206 \\
\hline Reakius Loed (Muldifamily) & & 1.28 & 4.18 \\
\hline
\end{tabular}




\begin{tabular}{|c|c|c|c|c|c|}
\hline \multirow[b]{2}{*}{ Packnge } & \multicolumn{5}{|c|}{ Component } \\
\hline & Cefing & Wols & Windows & $\begin{array}{l}\text { Iafildration } \\
\text { (ACH) }\end{array}$ & $\begin{array}{l}\text { Foundotion } \\
\text { (Uninentod } \\
\text { Base-1end) }\end{array}$ \\
\hline $\begin{array}{c}1 \\
2 \\
3 \\
4 \\
5 \\
6 \\
7 \\
8 \\
9 \\
10 \\
11 \\
12\end{array}$ & $\begin{array}{l}\text { R-0 } \\
R-7 \\
R-11 \\
R-19 \\
R-22 \\
R-30 \\
R-30 \\
R-38 \\
R-49 \\
R-38 \\
R+49 \\
R-60\end{array}$ & $\begin{array}{l}\text { R-0 } \\
R-0 \\
R-7 \\
R-7 \\
R-11 \\
R-13 \\
R-13 \\
R-19 \\
R-19 \\
R-19 \\
R-27 \\
R-34\end{array}$ & \begin{tabular}{c|}
$1-G$ \\
$1-G$ \\
$1-G$ \\
$2-G$ \\
$2-G$ \\
$2-G$ \\
$2 G$ LA \\
$2 G$ LA \\
2 CILA \\
Superwindow \\
Superwindow \\
Superwindow
\end{tabular} & $\begin{array}{l}0.8 \\
0.7 \\
0.7 \\
0.55 \\
0.55 \\
0.55 \\
0.55 \\
0.4 \\
0.4 \\
0.4 \\
0.4 \\
0.4\end{array}$ & $\begin{array}{l}\text { R-0 } \\
R-0 \\
R=0 \\
R-11 \\
R-11 \\
R-11 \\
R-11 \\
R-11 \\
R-19 \\
R-19 \\
R-19 \\
R-30\end{array}$ \\
\hline
\end{tabular}

\begin{tabular}{|c|c|c|c|c|c|c|c|}
\hline \multicolumn{6}{|c|}{ 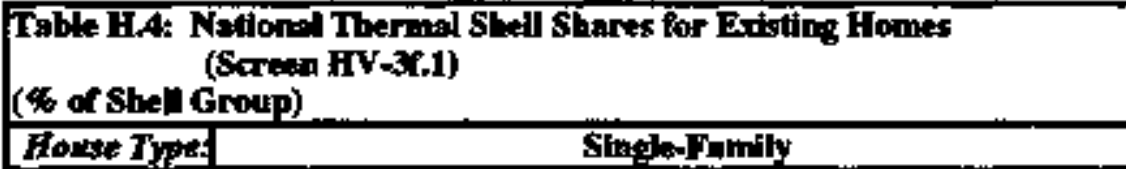 } & \multirow{2}{*}{ MF } & \multirow{2}{*}{$\frac{\text { MA }}{\text { All }}$} \\
\hline Sheli Group & EP & Ełoc & NGCA & Fuels: & Other & & \\
\hline $\begin{array}{c}\text { Peclage } \\
1 \\
2 \\
3 \\
4 \\
5 \\
6 \\
7 \\
8 \\
9 \\
10 \\
11 \\
12 \\
\end{array}$ & $\begin{array}{r}2.7 \% \\
5.1 \% \\
17.2 \% \\
9.5 \% \\
38.8 \% \\
16.7 \% \\
9.2 \% \\
0.9 \%\end{array}$ & $\begin{array}{r}14.1 \% \\
6.3 \% \\
14.2 \% \\
18.4 \% \\
36.3 \% \\
5.7 \% \\
5.0 \%\end{array}$ & $\begin{array}{r}5.9 \% \\
5.9 \% \\
18.5 \% \\
18.0 \% \\
39.1 \% \\
5.8 \% \\
6.5 \% \\
0.3 \%\end{array}$ & $\begin{array}{r}11.8 \% \\
15.7 \% \\
16.4 \% \\
24.6 \% \\
29.0 \% \\
1.6 \% \\
09 \%\end{array}$ & $\begin{array}{r}16.9 \% \\
9.0 \% \\
14.3 \% \\
15.7 \% \\
31.0 \% \\
6.8 \% \\
5.6 \% \\
0.8 \%\end{array}$ & $\begin{array}{r}7.7 \% \\
15.0 \% \\
5.2 \% \\
31.9 \% \\
32.9 \% \\
7.3 \%\end{array}$ & $\begin{array}{r}10.8 \% \\
19.6 \% \\
18.8 \% \\
15.6 \% \\
19.8 \% \\
5.1 \% \\
10.3 \%\end{array}$ \\
\hline Total & $100 \%$ & $100 \%$ & $100 \%$ & $100 \%$ & $100 \%$ & $100 \%$ & $100 \%$ \\
\hline $\begin{array}{l}1990 \text { Stock } \\
\text { (thopusands) }\end{array}$ & 4,429 & 7,781 & 15,215 & 28,912 & 8,027 & 24,415 & 5,212 \\
\hline \multicolumn{8}{|c|}{$\begin{array}{l}\text { (1) MF = Mndtifamily, MH = Manufactured Home. } \\
\text { (2) HP = Heat Pump, Elec = Electric Heat, NGCA = Natural Ges furnace/Cenoral Atr, Fuels = Oil and Gas } \\
\text { Other = LPG and Misc. } \\
\text { (3) Sounces: 1990 RECS (EIA 1993), Rischard et al. (1992), Ritscherd ind Hugng (1989). }\end{array}$} \\
\hline
\end{tabular}




\begin{tabular}{|c|c|c|c|c|c|c|c|}
\hline \multicolumn{8}{|c|}{ 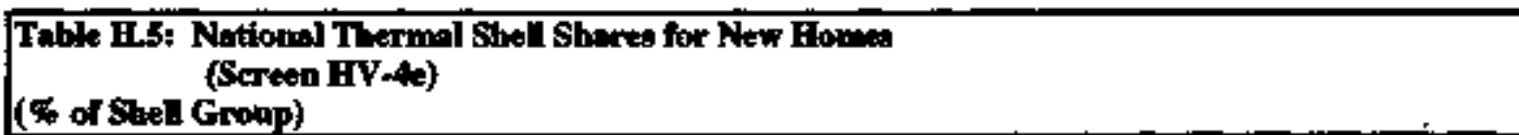 } \\
\hline Hotes Types & \multicolumn{5}{|c|}{ Sagle-Pansy } & $\overline{\mathbf{M F}}$ & MH \\
\hline 3befl Gracts & $\mathbf{H P}$ & Elec & NGCA & Fens & Othet & All & $\overline{A:}$ \\
\hline $\begin{array}{c}\text { Package } \\
1 \\
2 \\
3 \\
4 \\
5 \\
6 \\
7 \\
\text { B } \\
9 \\
10 \\
11 \\
12\end{array}$ & $\begin{array}{c}19.7 \% \\
2.1 \% \\
46.9 \% \\
28.6 \% \\
0.0 \% \\
2.6 \%\end{array}$ & $\begin{array}{c}42.2 \% \\
0.0 \% \\
10.1 \% \\
35.5 \% \\
0.0 \% \\
12.2 \%\end{array}$ & $\begin{array}{c}12.8 \% \\
0.9 \% \\
11.4 \% \\
58.4 \% \\
0.0 \% \\
16.5 \%\end{array}$ & $\begin{array}{r}7.0 \% \\
0.0 \% \\
9.5 \% \\
59.5 \% \\
0.0 \% \\
24.1 \%\end{array}$ & $\begin{array}{c}15.8 \% \\
0.0 \% \\
9.9 \% \\
50.9 \% \\
0.0 \% \\
23.3 \%\end{array}$ & $\begin{array}{l}65.4 \% \\
1.5 \% \\
8.9 \% \\
24.3 \%\end{array}$ & $\begin{array}{l}28.2 \% \\
23.3 \% \\
14.4 \% \\
31.2 \% \\
0.0 \% \\
2.8 \%\end{array}$ \\
\hline Total & $100 \%$ & $100 \%$ & $100 \%$ & $100 \%$ & $100 \%$ & $100 \%$ & $100 \%$ \\
\hline $\begin{array}{l}\text { (1) MF = Mol } \\
\text { (2) HP = Heat } \\
\text { Other = LPG a } \\
\text { (3) Soures: } 1 \\
\text { (4) New bonte }\end{array}$ & $\begin{array}{l}\text { nily, } M \\
\text { np, Elo } \\
\text { Misc. } \\
\text { RECS } \\
1980\end{array}$ & $\begin{array}{l}\text { Manfac } \\
\text { dectric } 1 \\
\text { 1993), }\end{array}$ & $\begin{array}{l}\text { Horte. } \\
\text { KGICA = } \\
\text { ard a al. } \\
\text { S. }\end{array}$ & al Ga & $\mathrm{cel} / \mathrm{Ce}$ & $\begin{array}{l}\text { Fuel } \\
899 \text {. }\end{array}$ & Ga: \\
\hline
\end{tabular}




\begin{tabular}{|c|c|c|c|}
\hline \multicolumn{4}{|c|}{ 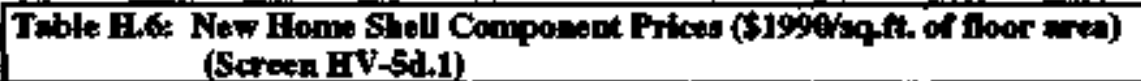 } \\
\hline \multirow{2}{*}{$\begin{array}{l}\text { Companenk } \\
\text { Desciptions }\end{array}$} & \multirow{2}{*}{$\begin{array}{l}\text { Component } \\
\text { Lerel }\end{array}$} & \multicolumn{2}{|c|}{ Nationn (Woshiston, DC) } \\
\hline & & 1-story & $2-\tan y$ \\
\hline $\begin{array}{l}\text { Ceiling } \\
\text { ceiting insutation } \\
R \text {-ualue }\end{array}$ & $\begin{array}{l}\text { R-0 } \\
R-7 \\
\text { R-11 } \\
R-19 \\
\text { R-22 } \\
\text { R-30 } \\
\text { R-38 } \\
\text { R-49 } \\
\text { R-60 }\end{array}$ & $\begin{array}{l}0.00 \\
0.21 \\
0.33 \\
0.47 \\
0.52 \\
0.65 \\
0.83 \\
1.03 \\
1.21\end{array}$ & $\begin{array}{l}0.00 \\
0.10 \\
0.16 \\
0.24 \\
0.26 \\
0.33 \\
0.42 \\
0.51 \\
0.61\end{array}$ \\
\hline $\begin{array}{l}\text { Wall } \\
\text { wall insulation } \\
\text { R-value }\end{array}$ & $\begin{array}{l}\text { R-0 } \\
R-7 \\
R-11 \\
R-13 \\
R-19 \\
R-27 \\
R-34\end{array}$ & $\begin{array}{l}0.00 \\
0.18 \\
0.28 \\
0.33 \\
0.47 \\
1.03 \\
1.22 \\
\end{array}$ & $\begin{array}{l}0.00 \\
0.20 \\
0.32 \\
0.37 \\
0.54 \\
1.18 \\
1.40\end{array}$ \\
\hline $\begin{array}{l}\text { Stob Edge } \\
\text { perimeter R-walue } \\
\text { and depth }\end{array}$ & $\begin{array}{l}R-0 \\
R-52 \mathrm{ft} \\
\mathrm{R}-54 \mathrm{ft} \\
\mathrm{R}-102 \mathrm{at} \\
\mathrm{R}-104 \mathrm{~A}\end{array}$ & $\begin{array}{l}0.00 \\
0.29 \\
0.37 \\
0.57 \\
0.74\end{array}$ & $\begin{array}{l}0.00 \\
0.15 \\
0.19 \\
0.30 \\
0.38 \\
\end{array}$ \\
\hline $\begin{array}{l}\text { Foor Insulotion } \\
\text { underfiloor R-value }\end{array}$ & $\begin{array}{l}R-0 \\
R-11 \text { flr } \\
R-19 \mathrm{fl} \\
\text { R-30 flr } \\
\text { R-38 fir }\end{array}$ & $\begin{array}{l}0.00 \\
0.41 \\
0.63 \\
0.77 \\
0.87\end{array}$ & $\begin{array}{l}0.00 \\
0.20 \\
0.31 \\
0.39 \\
0.44\end{array}$ \\
\hline $\begin{array}{l}\text { Infintutiotion } \\
A C H\end{array}$ & $\begin{array}{l}0.8 \\
0.7 \\
0.55 \\
0.4 \\
\end{array}$ & $\begin{array}{l}0.00 \\
0.00 \\
0.19 \\
0.37\end{array}$ & $\begin{array}{l}0.00 \\
0.00 \\
0.13 \\
0.26 \\
\end{array}$ \\
\hline $\begin{array}{l}\text { Window } \\
\text { no. of pones/design }\end{array}$ & $\begin{array}{l}\text { 1.0-gla } \\
\text { 2.0-gla } \\
\text { 2-gla loE } \\
\text { 2-gla koEAr } \\
\text { Spectrilly Sel. } \\
\text { Superwindow } \\
\text { Heat Minor }\end{array}$ & & \\
\hline \multicolumn{4}{|c|}{$\begin{array}{l}\text { (1) Sortces: Koomey et al. (1991b), Koomey et al. (1994b). Costs are for single- } \\
\text { Eamily homes. } \\
\text { (2) Costs normalized using average floor anea for new bomes: } 1500 \text { sq. fi. for } 1- \\
\text { story, and } 2200 \text { sq. ft for } 2 \text {-story. } \\
\text { (3) REEPS model oses 2-story costs for motionai model. }\end{array}$} \\
\hline
\end{tabular}

The HVAC equipment vintage block data are from the 1990 RECS. The vintage block shares are shown in Table H.7. REEPS also requires data on equipment capacity by house type, which are shown in Table H.8. Another important driver in the REEPS model is the unit energy consumption of various types of HVAC equipment. For this analysis, we derive UECs from the 1990 RECS (EIA 1993) for natural gas and oil equipment, and from the LBL Residential Forecasting Database (Hanford et al. 1994) for electric heating and cooling equipment Table H.9 shows the UECs for stock equipment. Market shares for the various HVAC systems are 
shown in Table H.10 and H.11 for stock and new homes, respectively. These data are from the 1990 RECS (EIA 1993) and the 1990 C-25 report (US Bureat of the Census 1991). In addition, REEPS requires data on the market share of room air conditioners in the housing stock, in order to forecast the saturation of room air units. For use in REEPS, these data are disaggregated according to the presence of central cooling equipment. Table H.12 shows the market share of room air conditioners by house type.

\begin{tabular}{|c|c|c|c|c|c|c|c|}
\hline \multicolumn{8}{|c|}{ 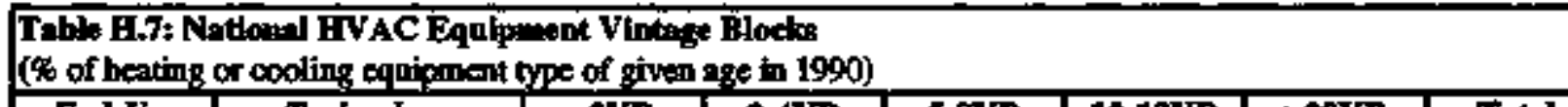 } \\
\hline End-Use & Technology & 2) & $24 \mathrm{KR}$ & 5.9YR & 1019YR & $>20 \mathrm{YR}$ & Total \\
\hline \multicolumn{8}{|c|}{ Festhin (Screen FV-3b,3) } \\
\hline & $\begin{array}{l}\text { Electric Funace } \\
\text { Gas Fumece } \\
\text { Oil Funace } \\
\text { LFG Fumace } \\
\text { Electric Heat Pump } \\
\text { Gas Hydronics } \\
\text { Oil Hydronics } \\
\text { Electric Room } \\
\text { Cas Room } \\
\text { Olher Egutament }\end{array}$ & $\begin{array}{l}4 \% \\
8 \% \\
9 \% \\
19 \% \\
12 \% \\
11 \% \\
9 \% \\
8 \% \\
6 \% \\
8 \%\end{array}$ & $\begin{array}{l}10 \% \\
15 \% \\
17 \% \\
19 \% \\
23 \% \\
9 \% \\
12 \% \\
11 \% \\
8 \% \\
25 \%\end{array}$ & $\begin{array}{l}24 \% \\
20 \% \\
17 \% \\
22 \% \\
39 \% \\
13 \% \\
15 \% \\
19 \% \\
15 \% \\
30 \%\end{array}$ & $\begin{array}{l}52 \% \\
31 \% \\
23 \% \\
27 \% \\
22 \% \\
26 \% \\
21 \% \\
33 \% \\
25 \% \\
27 \%\end{array}$ & $\begin{array}{l}9 \% \\
26 \% \\
34 \% \\
13 \% \\
4 \% \\
41 \% \\
43 \% \\
29 \% \\
46 \% \\
10 \%\end{array}$ & $\begin{array}{l}10 \overline{1} \\
100 \% \\
100 \% \\
100 \% \\
100 \% \\
100 \% \\
100 \% \\
100 \% \\
100 \% \\
100 \%\end{array}$ \\
\hline \multicolumn{8}{|c|}{ Cooling (Screos HV-3e 3) } \\
\hline & $\begin{array}{l}\text { Central Afr } \\
\text { Electric Hest Pump } \\
\text { Room Air }\end{array}$ & $\begin{array}{l}12 \% \\
10 \% \\
13 \%\end{array}$ & $\begin{array}{l}19 \% \\
26 \% \\
23 \%\end{array}$ & $\begin{array}{l}24 \% \\
39 \% \\
31 \%\end{array}$ & $\begin{array}{l}34 \% \\
23 \% \\
27 \%\end{array}$ & $\begin{array}{l}10 \% \\
2 \% \\
7 \%\end{array}$ & $\begin{array}{l}100 \% \\
100 \% \\
100 \%\end{array}$ \\
\hline
\end{tabular}

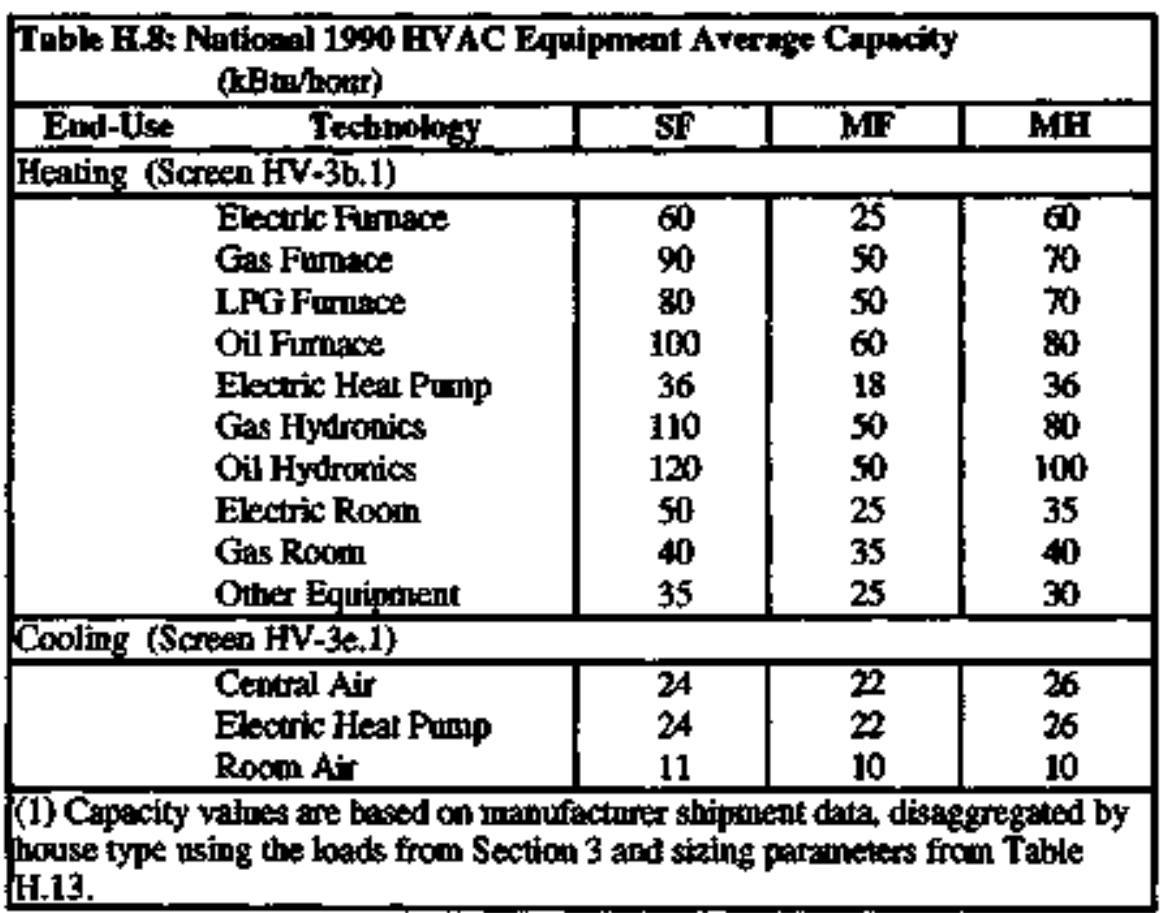




\begin{tabular}{|c|c|c|c|c|c|}
\hline \multicolumn{6}{|c|}{ 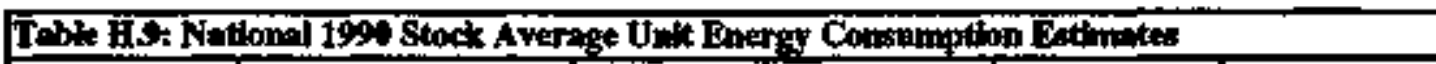 } \\
\hline Bnituse & Technolosy & Units & SP & MF & MH \\
\hline \multicolumn{6}{|c|}{ Aating: (Screen Hy-3b_s) } \\
\hline & 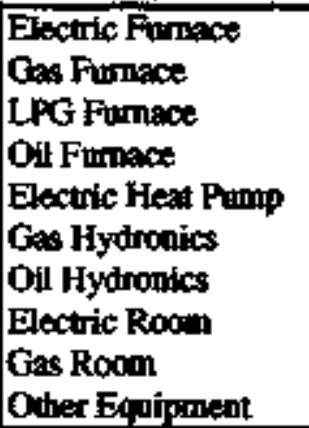 & 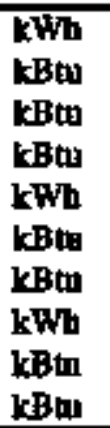 & $\begin{array}{r}7,200 \\
72,700 \\
44,800 \\
68,600 \\
5,800 \\
112,300 \\
114,400 \\
9,800 \\
43,200 \\
15,100\end{array}$ & $\begin{array}{r}5,200 \\
44,000 \\
40,900 \\
57,900 \\
2,500 \\
58,900 \\
54,700 \\
5,800 \\
26,900 \\
9,700\end{array}$ & $\begin{array}{r}5,800 \\
56,300 \\
31,000 \\
50,600 \\
2,200 \\
56,300 \\
50,000 \\
4,000 \\
39,300 \\
33,500\end{array}$ \\
\hline \multicolumn{6}{|c|}{ Ceoling (Screen $\mathrm{HV}-3 * 5$ ) } \\
\hline & $\begin{array}{l}\text { Central Air } \\
\text { Electric Heax Pump } \\
\text { Room Air }\end{array}$ & $\begin{array}{l}\mathbf{k W h} \\
\mathbf{k W h} \\
\mathrm{kWh}\end{array}$ & $\begin{array}{r}2,800 \\
3,400 \\
870\end{array}$ & $\begin{array}{r}1,600 \\
1,800 \\
530\end{array}$ & $\begin{array}{r}1,900 \\
2,300 \\
680\end{array}$ \\
\hline \multicolumn{6}{|c|}{ 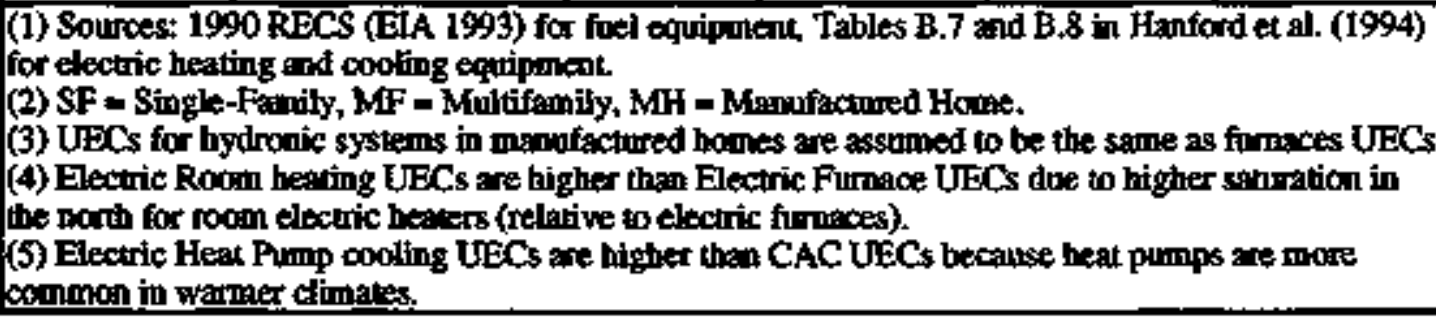 } \\
\hline
\end{tabular}

\begin{tabular}{|c|c|c|c|c|}
\hline \multicolumn{5}{|c|}{$\begin{array}{c}\text { Table H.10: Nations Existing Howe HVAC System Shores (Screen HV-3a.1) } \\
\text { (\% of house-type with given HVAC aystem) }\end{array}$} \\
\hline \multirow{2}{*}{ System No. } & \multirow[t]{2}{*}{ Cooling/Aleating Combination } & \multicolumn{3}{|c|}{ Housing type } \\
\hline & & S7 & Mir & MH \\
\hline 1 & Central Aivf Electric Furnace & $5.5 \%$ & $15.2 \%$ & $6.8 \%$ \\
\hline 2 & Centrai AinGas Furnace & $23,6 \%$ & $13.2 \%$ & $13.1 \%$ \\
\hline 3 & Centrat Air/LPG Funnace & $1.2 \%$ & $0.1 \%$ & 7.06 \\
\hline 4 & Cencral Airoil Furnace & $1.5 \%$ & $0.1 \%$ & $0.6 \%$ \\
\hline 5 & Central Air/Gas Hydronics & $0.5 \%$ & $0.6 \%$ & $0.0 \%$ \\
\hline 6 & Central Airoil Hydronics & $1.0 \%$ & $0.2 \%$ & $0,0 \%$ \\
\hline 7 & Central Airfother & Q.5\% & $0.0 \%$ & $0.4 \%$ \\
\hline 8 & Electric Heat Pomp & $6.9 \%$ & $5.7 \%$ & $1.8 \%$ \\
\hline 9 & No Central AtriGas furnace & $19.2 \%$ & $10.2 \%$ & $23.1 \%$ \\
\hline 10 & No Centrel Ait/LPG Fumace & $3.8 \%$ & $0.2 \%$ & $15.3 \%$ \\
\hline 11 & No Central AirfOil Furnace & $4.9 \%$ & $13 \%$ & $4.8 \%$ \\
\hline 12 & No Central Ait/Gas Hydronics & $4.7 \%$ & $19.4 \%$ & $0.0 \%$ \\
\hline 13 & No Central Air/Oil Hydronics & $4,2 \%$ & $9.5 \%$ & $0.0 \%$ \\
\hline 14 & No Central Alr/Electric Rocm & $6.6 \%$ & $12.6 \%$ & $13.1 \%$ \\
\hline 15 & No Central AitrGas Room & $9.0 \%$ & $10.1 \%$ & $1.7 \%$ \\
\hline \multirow[t]{2}{*}{16} & No Centril AirfOther & $6.6 \%$ & $1.7 \%$ & $12.2 \%$ \\
\hline & Totats & 1008 & $100 \%$ & $100 \%$ \\
\hline
\end{tabular}




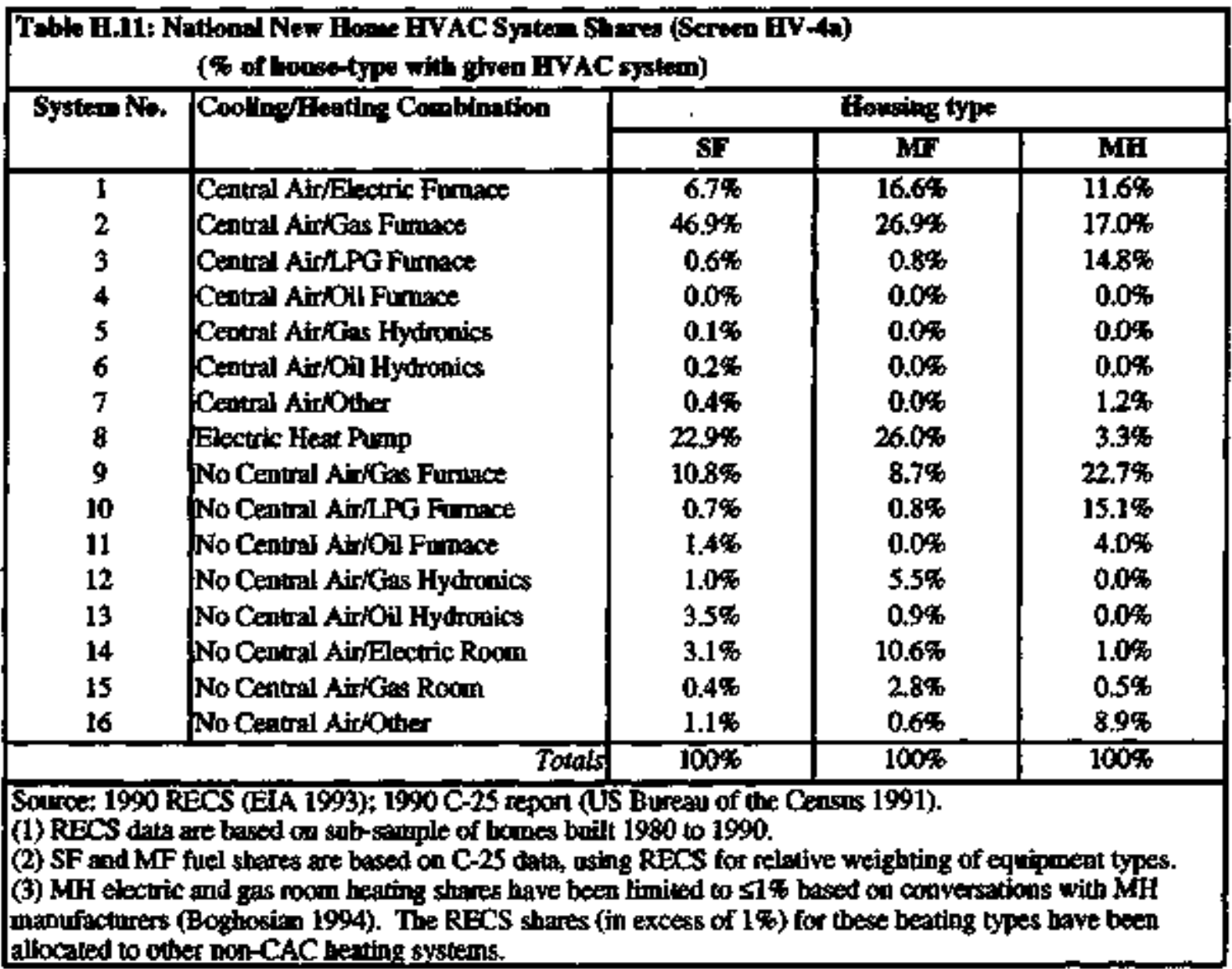

\begin{tabular}{|c|c|c|c|}
\hline \multicolumn{4}{|c|}{ 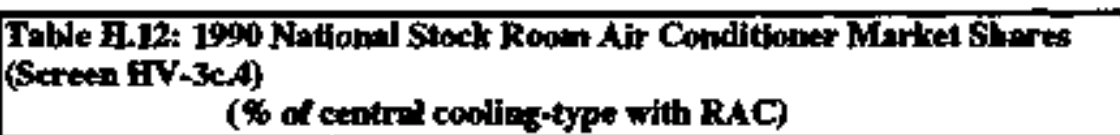 } \\
\hline \multirow[t]{2}{*}{ Centril Conling Systen } & \multicolumn{3}{|c|}{ Housting type } \\
\hline & $\overline{\mathrm{SF}}$ & $\mathbf{M F}$ & MH \\
\hline $\begin{array}{l}\text { Central Aí } \\
\text { Heat Pump } \\
\text { No Centrl Air }\end{array}$ & $\begin{array}{l}7.7 \% \\
3.5 \% \\
47 \%\end{array}$ & $\begin{array}{l}1.4 \% \\
0.0 \% \\
49 \%\end{array}$ & $\begin{array}{l}5.6 \% \\
0.0 \% \\
44 \%\end{array}$ \\
\hline Source: 1990 RECS FitA 199 & & & \\
\hline
\end{tabular}

In order to calculate national decision models, we must estimate the cost of HVAC equipment, which in tum reguires estimates of equipment size. Esuipment is usually sized to meet the peak load; Table H.13 presents the parameters used to calculate national average peak load. This load is subsequently used to estimate equipment sizing parameters, which are presented in Table H.14. These paraneters indicate the extent to which HVAC equipment is oversized for meeting the peak load. The cost of HVAC equipment is calculated using the same equation as the regional models because this equation was based on national data (the resulting costs vary from the regional models, however, due to different equipment sizes). 


\begin{tabular}{|c|c|c|}
\hline \multicolumn{3}{|c|}{$\begin{array}{l}\text { Table H.13; Peak Thermal Load as a Fonction of Annual Land } \\
\text { for Nathonid Madel }\end{array}$} \\
\hline Flesting & $\begin{array}{c}\text { skope } \\
\text { (kBthh/Bm) }\end{array}$ & $\begin{array}{l}\text { Intertopt } \\
\text { (1:Btuh) }\end{array}$ \\
\hline Single.Fanily & 0.527 & 8.197 \\
\hline Molcúfanily & 0.436 & 6.787 \\
\hline Cooting & $\begin{array}{c}\text { slope } \\
\text { (kBtah/kBtn) }\end{array}$ & $\begin{array}{l}\text { inlercept } \\
\text { (kBub) }\end{array}$ \\
\hline Single-Family & 2.029 & -1.862 \\
\hline Mulutfanily & 1.597 & -1218 \\
\hline $5,1$. & $8 \mathrm{DOE}-$ & Fith th \\
\hline
\end{tabular}

\begin{tabular}{|c|c|c|c|}
\hline & $\mathbf{S P}$ & MF & MA \\
\hline \multicolumn{4}{|l|}{ Aeating } \\
\hline Electric Fonace & 1.76 & 1.60 & 1.81 \\
\hline Gas Furnace & 2.06 & 1.89 & 2.07 \\
\hline Oil Furmace & 2.15 & 1.99 & 2.18 \\
\hline Electric Heat Punsp & 1.48 & 1.46 & 1.62 \\
\hline Gas Hydronics & 2.39 & 1.94 & $\mathbf{n} / \mathbf{a}$ \\
\hline Oil Hytroaics & 2.44 & 2.08 & nda \\
\hline Electric Roomi & 1.80 & 1.65 & 1.72 \\
\hline Ges Room & 1.54 & 1.61 & 1.61 \\
\hline Other Equipmert & 1.90 & 1.97 & 2.01 \\
\hline \multicolumn{4}{|l|}{ Cooling } \\
\hline Contral Air & 1.60 & 0.84 & 1.07 \\
\hline Electric Heat Pomp & 1.29 & 1.03 & 1.42 \\
\hline Room Air & 0.65 & 0.55 & 0.68 \\
\hline \multicolumn{4}{|c|}{ 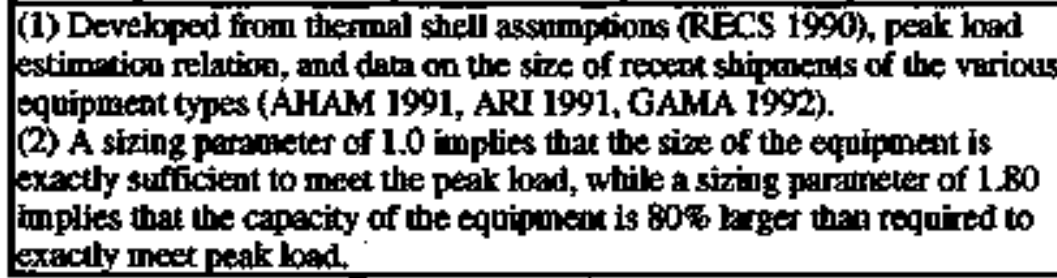 } \\
\hline
\end{tabular}

\section{H.2 Decision Models}

The national HVAC model employs the same decision equations and parameters as the regional models because the parameters for these equations have all been calculated using national data. Refer to Section 6 of the main report for the methods and data used in specifying the HVAC decision models. 
One may question the accuracy of the regional model market share forecasts, because they use the same decision parameters as the national model. While both use the same decision model, the purchase results will difter becanse the disaggregated (regional) models capture dependencies in the structure of consumer decision-making that are not apparent in the aggregated model due to the non-linear nature of the consumer choice models. The purpose of distinguishing between North and South models is thus not to account for differences in consumption, for this could be more easily accomplished in a spreadsheet model. Rather, the purpose is to recognize that the circumstances under which decisions are made are intzerently different in the two regions due to differences in important factors such as climate, gas availability, and construction practices. Thus we believe that there are no significant regional differences in consumers' decision criteria, but that the different decision environment will lead to different punchase decisions. By applying the decision models separately to the North and South regional data, the dependent variables (consumer purchase decisions) will more accurately reflect the actual environment in which decisions are made. The same principle is applicable to the distinction between small and large single-family homes, becatuse the decision envinonments are inherently diffenent in the two cases. The market share data from RECS bear this out, with significantly different HVAC system market shares for large and small homes, reflecting both typical construction practices and the economics of particular equipment choices. Both regional and house-type disaggregations point to the fact that REEPS is not simply a tool for assessing end-use consumption, but rather a tool for assessing consumer decision-making. The resulting end-use consumption is metely a conseguence of the decistions modeled during the course of the forecast.

\section{H.3 Model Executton in REFPS}

One of the advantages of the national HVAC model is that it can be nun simultaneously with the national appliance inodels developed by LBL (see companion report, L.BL \#34046). In practice to use the regional REEPS model requires ruming three separate models in REEPS: North HVAC, South HVAC, and appliances. The national model saves time in two ways. First, the national model only has one set of REEPS input files, so it takes less time to change model parameters in order to forecast the effect of policies. In most cases these model changes are not a significant burden, but when modeling several scenarios or policies the extra time and possibility for mistakes can be significant with the regional (2-model) version. The second advantage of the national model is that it avoids the need to aggregate forecast results after model execution. These features of the national model ane most useful in quick-reaction policy modeling situations.

\section{H.4 Choosing the Appropriate Model}

When faced with the option of using two aiternative models, the question inevitably arises: What benefits can one gain from the added effort required to run the regional models rather than the national model? Use of the two regional models can sometimes amount to two or mone times the amount of work compared to the national model. Furthermore, some analyses require only highily aggregated numbers which obseure the original detail of the regional models. Thus the analyst needs a benchmark or indicator to identify those cases for which the regional models significantly improve the results.

First, total base-year consumption by end-use is not a useful benchmark for identifying differences in the models' results. Since REEPS is calibrated to the Unit Energy Consumption values, the base-year consumption can alwoys be reproduced when the UECs are based on a consistent single source, namely RECS. Thus, because the UEC input data for the two models are from the same source, the base-year end-use consumption would be roughly the same. The base-year consumption is mainly useful as a mechanical check as to whether the number of households, market shares, etc. have been entered correctly and consistently. 
Another possible indicator for comparison is the end-use consumption over the forecast period. The end-use consumption by itself is not a sufficient basis for comparison, but should be compared in conjunction with the other key variables: Thermal Integrity, Thermal Shell Shares, HVAC System Market Shares, Efficiency, Usage, and Stock Tumover. If these variables yield similar results in both models, then the model results are not sensitive to the 2-region disaggregation under the given exogenous assumptions. Since the comparison is often conducted for a reference or base case, however, one cannot be certain the comparison would be as favorable when the exogenous variables include a drastic change, such as a price shock, a set of stringent standards, or the introduction of an advanced technology that is expected to gain considerable market share. These circumstances require more caution in using the models interchangeably.

Although there is no way to know a priori whether a particular set of nuns will be sensitive to the disaggregation, there are a few rules of thumb which can be used to narrow the set of parameters ased in comparing the models.

(1) Mechanically check base-year end-use consumption numbers when there is a possibility of differences in conventions between the national and regional models. In other words, if exogenous variables are changed in structure or value, the comparison can reveal numerical or structural mis-specifications.

(2) Compare the relevant forecast variables for a 20 -year period for the national and regional models whenever there are significant departures from the base case. In other words, the comparison provides a measure of the sensitivity of the model results to those cases which serve as jumping off points for other analyses. For example, the comparison could be made for a business-as-usual case, a max. tech. case, and a minimum life-cycle cost case in order to determine model sensitivity across a tange of scenarios.

(3) When the policies are concerned only with one area of improvement, such as efficiency improvements in heating and cooling equipment, the national model will generally suffice. On the other hand, when the relationship among different improvements is considered, such as between thermal shell and equiptnent efficiency, the disaggregated model is preferable.

(4) If the only issue is fuel price sensitivity, the national model will probably suffice because the regional sensitivity to fuel price is small, and fuel price forecasts are often not available by region anyway. The same point applies to other exogenons variables that are not available independently by region, such as housing starts.

As these rales of thumb suggest, the main distinction between the national and regional models is methodological and does not always show up in the end-use consumption totals. Thus some care is necessary in choosing the appropriate model(s) where disaggregated models are available.

\section{H.5 National HVAC Model Sunmary}

Certain applications of forecasting models do not require regional detail or do not allow the time needed to produce detailed regional results. For these cases, we have developed an aggregated, national REEPS HVAC model. The model was developed using the same methodology as the regional models, and the modeling structure differs only in minor aspects. despite their similarities, however, we do not expect that the models will yield identical results. A future report in this series will investigate the differences in model results between the national and regional REEPS HVAC models. 


\section{APPENDDX I: REDUCED-FORM THERMAL INTEGRUTY COST CURVES}

One of the features of the REEPS 2.1 model that most distinguishes it from other end-use forecasting models is the thermal shell model docmmented in Section 3 . The detailed treatment of the physical building characteristics allows for accurate modeling of changes in space conditioning loads. For those end-use forecasting models, such as the LBL Residential Energy Model, that do not treat the thermal shell in detail, we have developed reduced-form cost vs. efficiency curves. Tables I.1-1.3 and Figures I.1-I.3 document these relationships for new shells of the three housing types in the national model (single-family, multifamily, and manufactured homes). It is interesting to note that the curves have similar forms for all three hoursing types (due to the same shell measure for the corresponding points on each curve), but the magnitude of cost increases and thermal integrity improvements differ. Also keep in mind that the thermal integrity improvements shown in the figures are relative to shell package $\# 1$, which is essentially uninsulated. These results do not imply that space conditioning load for typical new shells can be neduced by $70-80 \%$. Note that these curves are not used in the REEPS model, but are only provided for use in other modeling applications.

The analysis documented in this Appendix is based on the new construction thermal shell components and prices presented in Sections 3.1 and 3.4. The space conditioning laads are based on the national shell packages described in Appendix $H$. 


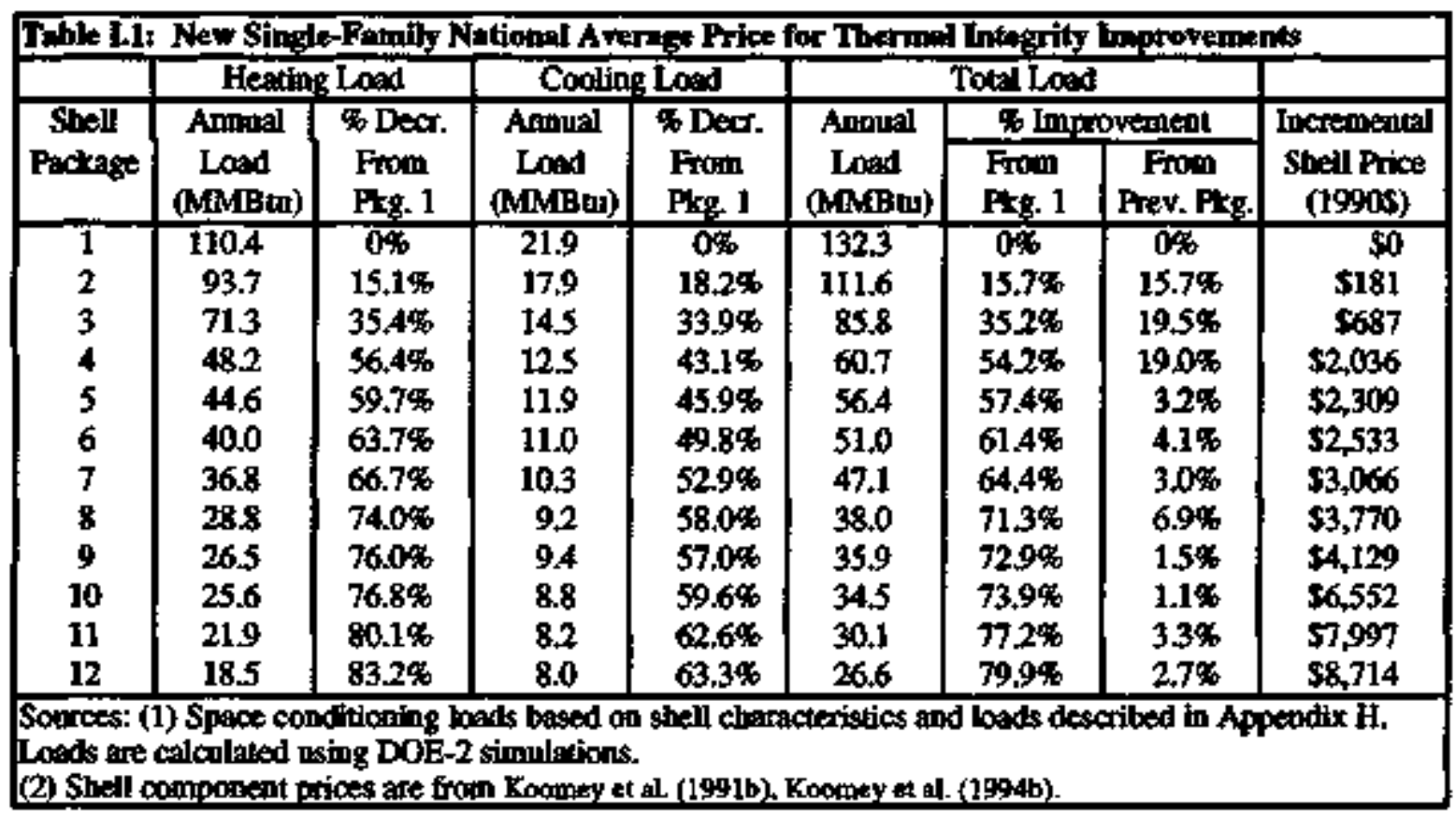

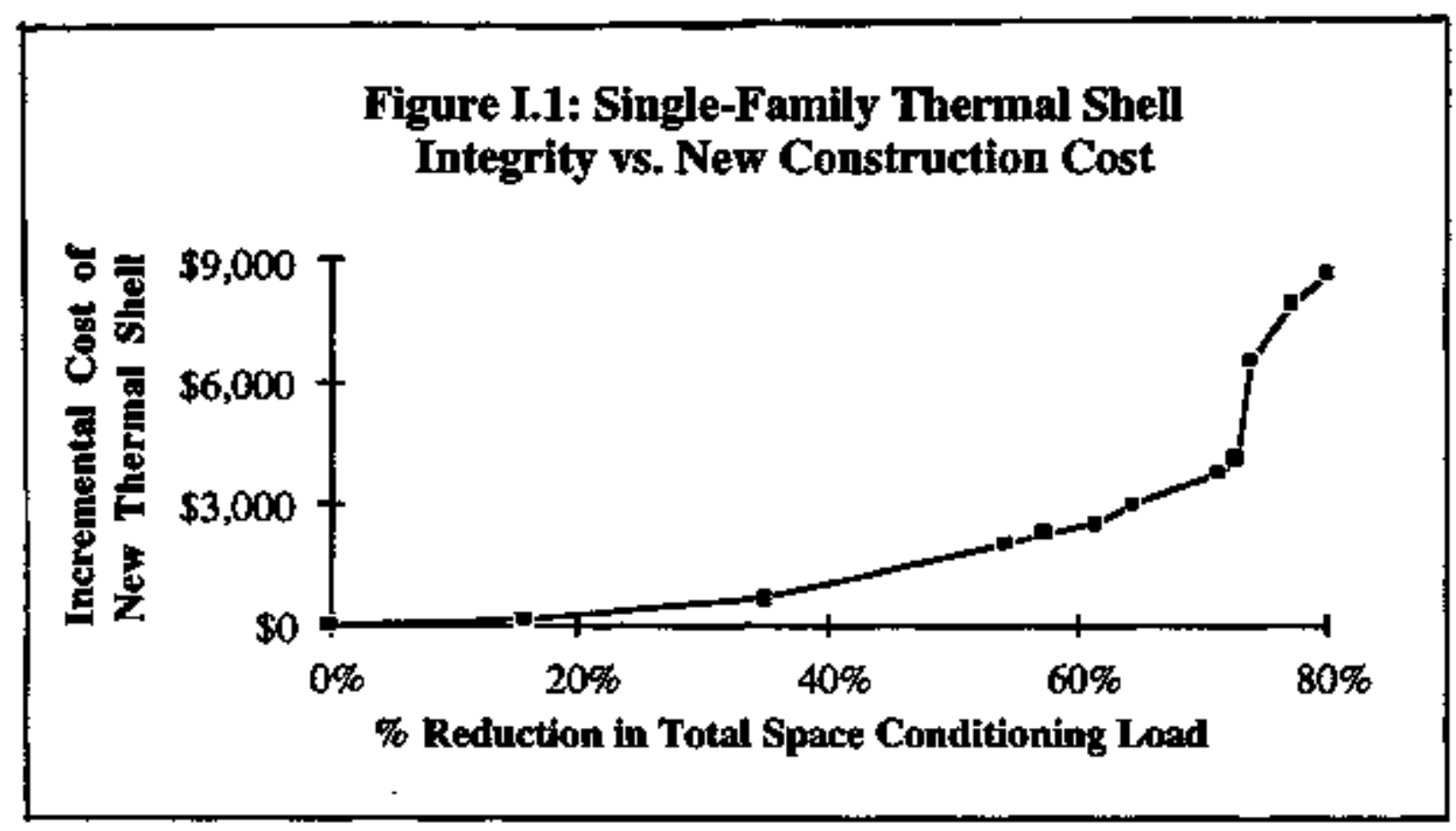




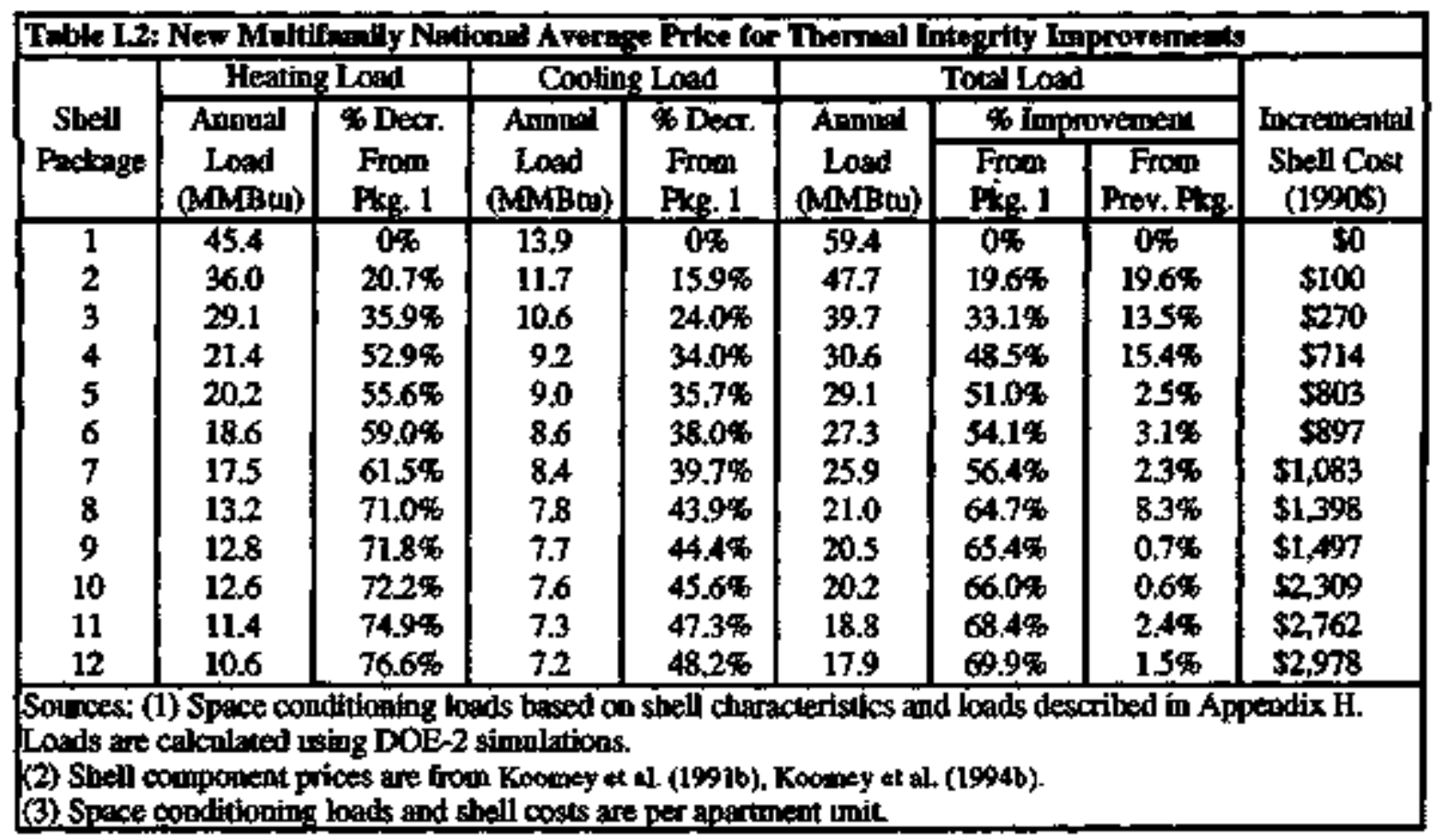

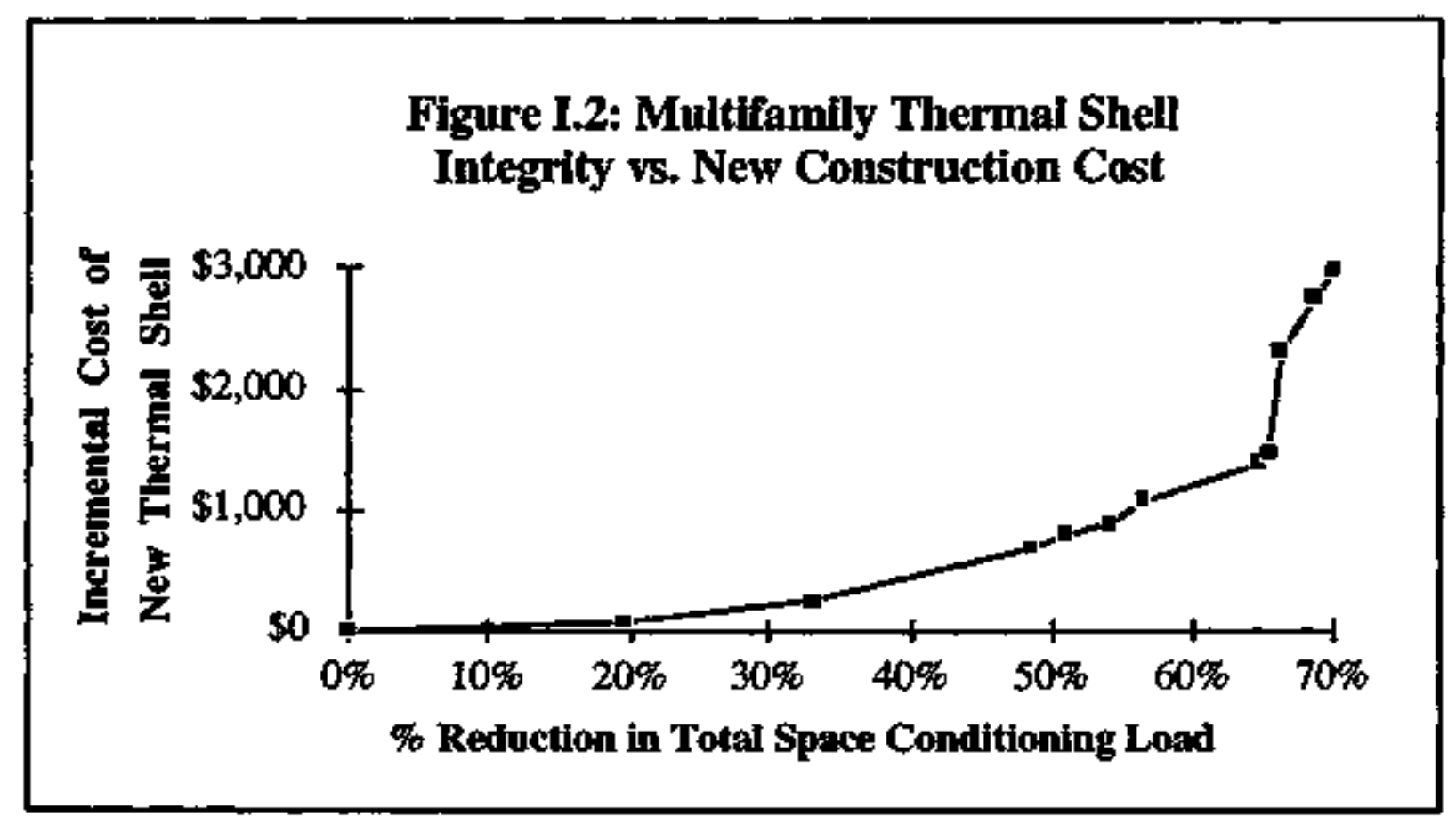




\begin{tabular}{|c|c|c|c|c|c|c|c|c|}
\hline \multirow{3}{*}{$\begin{array}{c}\text { Shell } \\
\text { Paxtrage }\end{array}$} & \multicolumn{2}{|c|}{ Heatip Load } & \multicolumn{2}{|c|}{ Cooling Loed } & \multicolumn{3}{|c|}{ Total Load } & \multirow{3}{*}{$\begin{array}{l}\text { Incrimentel } \\
\text { Shell Cost } \\
\text { (19905) }\end{array}$} \\
\hline & \multirow{2}{*}{ 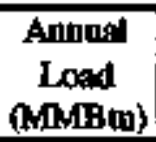 } & \multirow{2}{*}{$\begin{array}{l}\text { \% Decr. } \\
\text { From } \\
\text { Plkg. } 1\end{array}$} & \multirow{2}{*}{$\begin{array}{l}\text { Annoal } \\
\text { Load } \\
\text { (MMBto) }\end{array}$} & \multirow{2}{*}{$\begin{array}{l}\text { SDect. } \\
\text { From } \\
\text { Ptop } 1\end{array}$} & \multirow{2}{*}{$\begin{array}{c}\text { Aminal } \\
\text { Load } \\
\text { (MMBto) }\end{array}$} & \multicolumn{2}{|c|}{ \& Improvement } & \\
\hline & & & & & & From & $\begin{array}{c}\text { From } \\
\text { Prev, Prg. }\end{array}$ & \\
\hline$\overline{1}$ & 93.5 & 030 & 18.7 & $0 \%$ & 112.2 & $0 \%$ & (\$) & 50 \\
\hline 2 & 72.7 & $223 \%$ & 13.4 & $28.2 \%$ & 86.1 & 23.38 & $23.3 \%$ & 5250 \\
\hline 3 & 57.8 & $38.2 \%$ & 10.9 & $41.5 \%$ & 68.7 & $38.8 \%$ & 155\% & $\$ 631$ \\
\hline 4 & 36.1 & $61.4 \%$ & 10.2 & $455 \%$ & 46.2 & 58.8 & $20.0 \%$ & $\$ 1,896$ \\
\hline 5 & 33.3 & $64.3 \%$ & 9.6 & $48.4 \%$ & 43.0 & $61.7 \%$ & $2.9 \%$ & $\$ 2,092$ \\
\hline 6 & 29.9 & $68.0 \%$ & 8.9 & $52,3 \%$ & 38.8 & $65,4 \%$ & $3.7 \%$ & $\$ 2,316$ \\
\hline 7 & 27.7 & $704 \%$ & 8.4 & $54.8 \%$ & 36.1 & $67.8 \%$ & $24 \%$ & $\$ 2,684$ \\
\hline 8 & 21.9 & $76.6 \%$ & 7.6 & $59.5 \%$ & 29.4 & $73.8 \%$ & $59 \%$ & $\$ 3,246$ \\
\hline 9 & 18.7 & $80.0 \%$ & 7.9 & $57.8 \%$ & 26.6 & $76.3 \%$ & $2.5 \%$ & $\$ 3,742$ \\
\hline 10 & 18.5 & 80.26 & 7.6 & $59.3 \%$ & 26.1 & $76.7 \%$ & $0.5 \%$ & $\$ 5,301$ \\
\hline 11 & 15.9 & $83.0 \%$ & 7.1 & $62.1 \%$ & 23.0 & $79.5 \%$ & $2.8 \%$ & $\$ 6,285$ \\
\hline 12 & 12.7 & $86.4 \%$ & 7.1 & $62.0 \%$ & 19.8 & $82.3 \%$ & $28 \%$ & $\$ 6,935$ \\
\hline
\end{tabular}

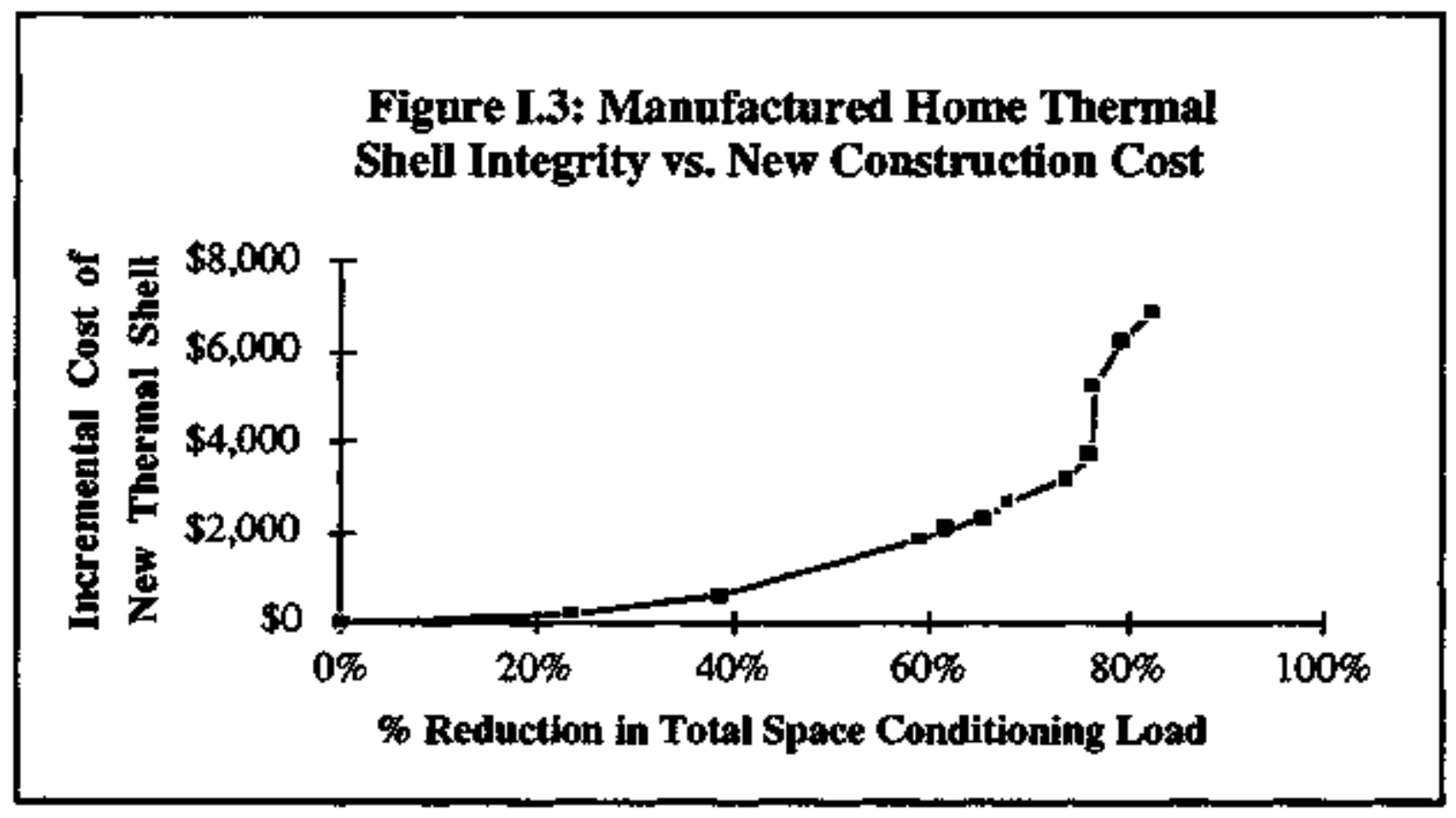

